Portland State University

PDXScholar

1972

\title{
The transition to Nazism, the history of the German town of Pfungstadt, 1928 to 1935
}

\author{
David E. Arns
}

Portland State University

Follow this and additional works at: https://pdxscholar.library.pdx.edu/open_access_etds

Part of the Political History Commons, Politics and Social Change Commons, and the Public Affairs, Public Policy and Public Administration Commons

Let us know how access to this document benefits you.

\section{Recommended Citation}

Arns, David E., "The transition to Nazism, the history of the German town of Pfungstadt, 1928 to 1935 " (1972). Dissertations and Theses. Paper 968.

https://doi.org/10.15760/etd.968

This Thesis is brought to you for free and open access. It has been accepted for inclusion in Dissertations and Theses by an authorized administrator of PDXScholar. Please contact us if we can make this document more accessible: pdxscholar@pdx.edu. 
AN ABSTRACT OF THE THESIS OF David E. Ams for the Master of Arts in H1story presented July 24, 1972.

Title: The Transition to Nazism, The History of the German Town of Prungstadt, 1928 to 1935.

APPROVED BY MEMEERS OF THE THESIS COMMITHEE:
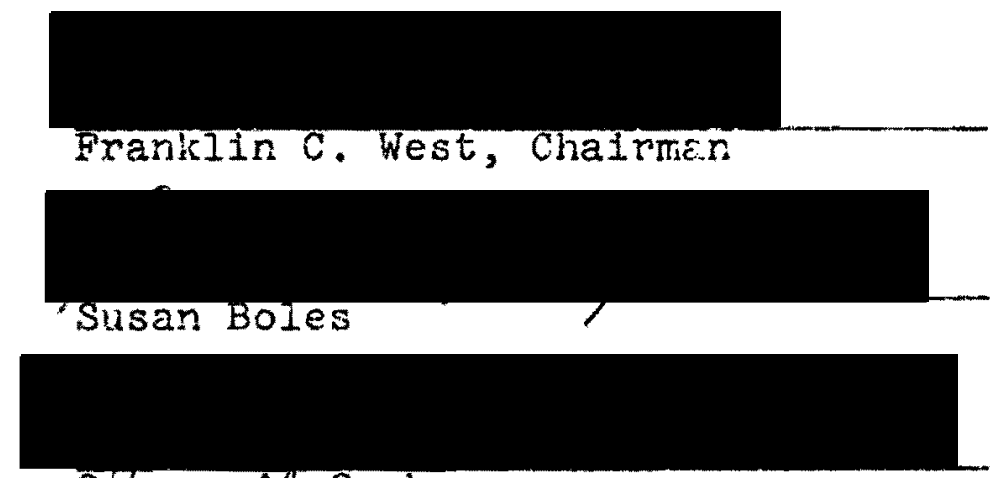

Geprge A/f Carbone

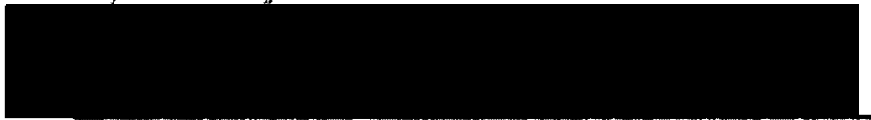

Pauli V. Vehvilalnen

Pfungstadt is a small German town which to date has not earned a footnote in the historles of either the weimar Republic or the Third Re1ch. Based upor the efforts or men In towns like Pfungstadt (and towns which were not isks Pfungstadt) the members of the Nazi party built a politicaI structure which reached to the pinnacle upon which Adolf Hitler stwod. Fesearching the growth of the Nazi party, the intense struggles that occlired with denocratic forces, the selzure of power and the installation of a workable system of government is the problen. This thesis in no 
way purposts to be more than a study of the history of the town of Pfungstadt between 1928 and 1935 .

Slich a research problem demands field research. Dura period of four months (September, 1971, to January, 1972) I Ilved in Pfungstadt. The main sources of the date which I gathered during that time were the town's newspapen, the Pfungstädter Anzeiger, and the SPD newspaper, which was published in Darmstadt, the Hessischer Volksirreuna. Daliy accounts of the political and soctal events in Pfungstadt were carried in the Anzelger; the Volksfreund contalned a predominate amount of SPD party activities. Also consulted were varlous records from the town hall's archives. Supplementing, putting sore flesh on the bones of the written records of Pfungstadt's history, were personal interviews with all of the living political leaders of the age, plus a broad cross-section of the general populace. The backbone of Pfungstadt's soclety was the middle class. Imbedded within that class were the seeds of Nazism. The working class was divided along politicai lines between the SPD (Soc1al Democrats) and the KPD (Communists). The working class and the middle class (the bürgerlich), political competitors since the 1890's, grew wider and wider apart in political outlook with the advent of the depression in 1929. Igrowing their old association with liberalism, first a small portion, and then, by 1932 , nearly the entire middle class fell into the Nazt's hands. 
The working class fought a double-barreled battle of its own. The KPD constantly scored the SPD for losing its "class icentity" and took a slzabie portion of the SPD's traditional electorate. The SPD, not desiring the radical programs of the KPD, formulated a liberal set of objectives, but was not able to stem the tide which was runntrig for a "change."

Democracy died in Pfungstadt because of the shortsighted vision of the middle class, a shortsightedness brought on by the seemingly insolvable depression. Faced with a choice, in their minds, between losing their social and political signiflcance and voting for a change (any change) the middle class succumbed to an overwhelming political immaturlty and voted for the Naz1s. On March 7, 1933, with the mlddle class support: assured, the Nazis selzed power with the assistance of SA members from Darmstadt. Once in physical control of the town, a systemat1c series of measures assisted the Nazis in coordinating the town into their system. Everyone in Pfungstadt then was forced to pay an exorbitant price for the political blindness of the bürgerlich. 
THE TRANSITION TO NAZISM, THE HISTORY OF THE GERMAN TOWN OF PFUNGSTADT, 1928 TO 1935

\author{
by \\ DAVID E. ARNS
}

A thesis submitted in partial fulfillment of the requirements for the degree of

\author{
MASTER OF ARTS \\ in \\ HISTORY
}

Portland State Unlversity

1972 
TO THE OFFICE OF GRADUATE STUDIES:

The members of the committee approve the thesis of Dav1d E. Arns presented JuIy $27,1972$.
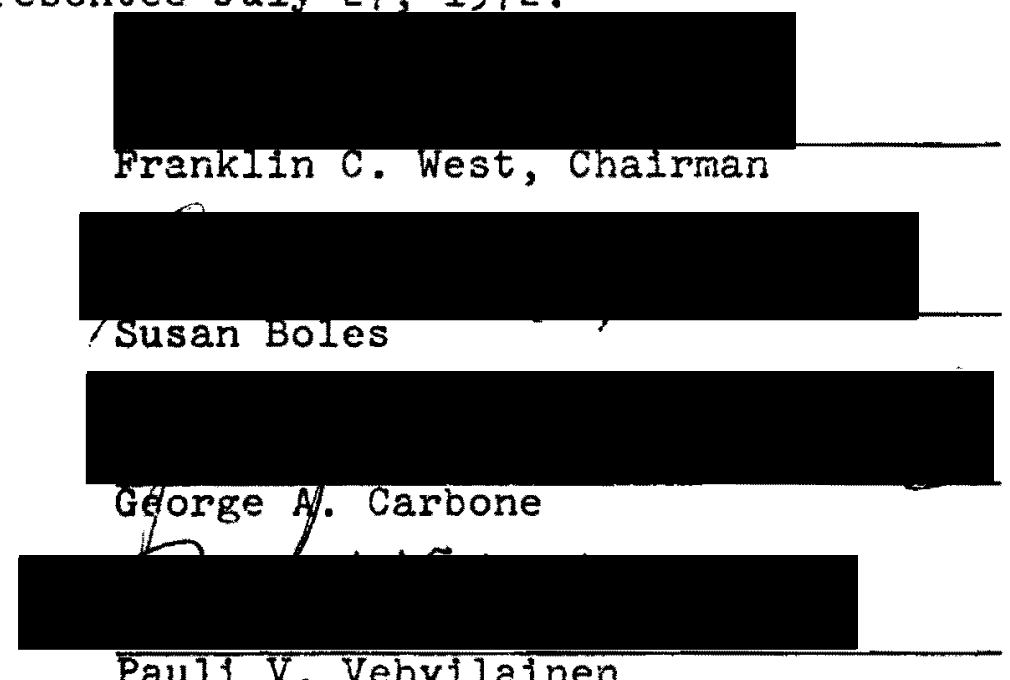

\section{APPROVED :}

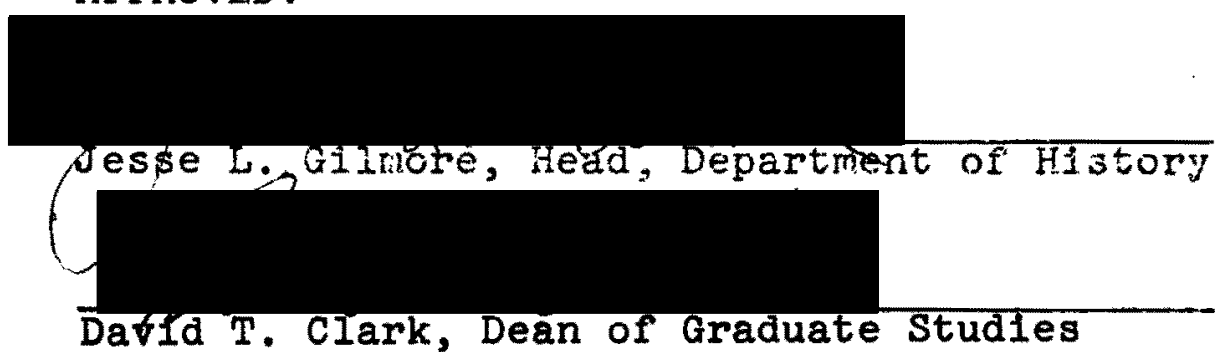

Juily 27,1972 


\section{ACKNONLEDGNENTS}

In the course of prevaring this thesis I have been ably assisted by many people. I wouid especlally like to thank Hidde Hanbuch who provided the wonderful accoramodations in Germany while I gathered the material for this study; KarI Hechler who opened many of the doors in Pfunestadt for me so that I might speak to some of the main political leaders and gather the1r knowledge of the perlod; Gudrun Arns, Eugenia A. Arns, and Robert S. Arns for their valuable assistance, criticism and concern; Dr. Franklin C. West for his hours of patient support and inspiration. A speclal word of thanks must also go to the people of Pfungstadt. 


\section{LIST OF FIGURES}

FIGURE

P.AGE

1 The area surrounding Pfungstadt

2 The town of Pfungstadt 
TABLE OF CONTENTS

PAGE

ACKNOWLEDGMENTS . . . . . . . . . . . . .

LIST OF FIGURES . . . . . . . . . . . . IV

\section{CHAPTER}

PART I THE GROWTH OF POLITICAL DISENCHANTMENT 1928-1931

I THE BACKGROUND . . . . . . . . . . 2

II PFUNGSTADT'S STRUCTURE . . . . . . 18

III THE REIGN OF NORMALCY - 1928 . . . . 40

IV RIPPLES OF REBELLION - 1929 . . . . . 73

V REALIGNING SOCIETTY - JANUARY, 1930 TO JULY, 1930 . . . . . . . . 115

VI BASIC ADJUSTMENTS - JULY, 1930 TO JANUARY, 1931 . . . . . . . . . 137

PART II THE EROSION OF REASON 1931-1933

VII A NEW NORMALCY - JANUARY, 1931 TO JULY, 1931 . . . . . . . . . .

VIII REACTION TO THE DEPRESSION JULY, 1931 TO JANUARY, 2932 • . . .

IX OLD MOODS, NEW METHODS JANUARY, 1932 TO JULY, 1932 . . . .

$X$ SEARCHING FOR A SOLUTION JULY, 1932 TO JANUARY, 1933 . . . .

PART III THE NAZI TRIUMPH 1933-1935

XI THE FINAL AGONIZING ACT JANUARY AND FEBKUARY, $1933 . . ., \cdot$ 
CHAPTER

XII THE NAZI SEIZURE OF POWER - MARCH, 1933

XIII EEARNING TO MARCH IN STEF -

APRIL TO JULY, 1933 . . . . . . . . 358

XIV ADJUSTING TO NAZI ORDERS JULY TO OCTOBER, 1933 . . . . . . . 396

XV THE NEW MASTERS - OCTOBER, 1933 TO JANUARY, 1934 .......... 414

XVI NAZI PFUNGSTADT - 1934 . . . . . . 432

XVII AN ASSESSMENT ............. . . 444

REFERENCES . . . . . . . . . . . . . 4 455

APPENDICES . . . . . . . . . . . . . 4 457 
PART I

THE GROWTH OF POLITICAL DISENCHANTMENT

1928 TO 1931 
CHAPTER I

THE BACKGROUND

Situated in southwestern Germany is the pleasant little town of Pfungstadt. It is located $\mathrm{s} 1 \mathrm{x}$ miles south of Darmstadt, seven miles east of the Rhine River, five miles west of the Odenwald (hills), and thirty-six miles north of Heldelberg. ${ }^{1}$ Beauty, learning, and history literally encircle 1t. Within these confines the people of Pfungstadt played their roles on the stage of history.

A considerable collection of Roman artifacts attest to the early presence of inhabitants in the area, although the oldest survivirg written reference to the town of "Phungestat" dates from $785 .{ }^{2}$ In that year the records of the abbey Lorsch report the bequest of three mills to the monks. The records periodically mention other gifts as late as 1037.3 No other town under Lorsch's administration could claim so many mills, because the Modau, whlch flows from the Odenwald through Pfungstadt, is one of only three streams between Darmstadt and Heldelberg which discharge Into the Rhine. Past Pfungstrdt the land becomes too flat for the stream to generate a urrent strong enough to turn

Darmstadt was the capital of the Iand (state) Hesse-Darmstadt througnout: the We1mar Republic. 


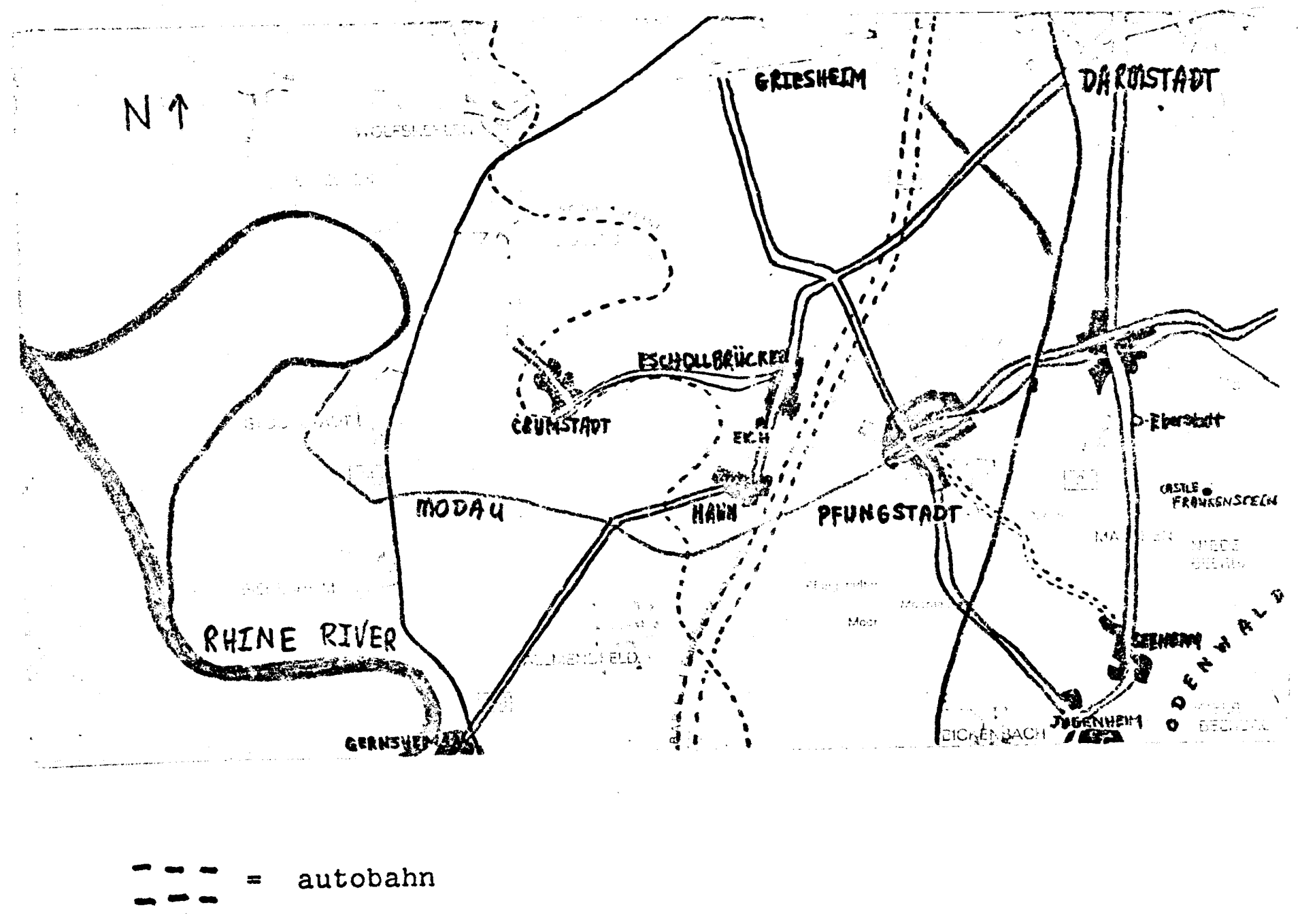


a mill-wheel. 5 No records exist that establish whether or not the abbey still controlled its interests in Pfungstadt after 1232.

The noble Katzenellnbogen family certainly had acquired possession of the territory around the town by 1318 and held sway over the area until the marriage of Anna, the daughter of the last of the Katzenellnbogens to Henry III of Hessen in $1479 .^{6}$

From the 16th until the early 18 th century, the town and the business of the mills stagnated under the impact of a succession of wars. The Reformation brought with it Landgraf Phillip of Hessen who assembled his soldiers near Pfungstadt in 1534 in order to face the challenge of the Schwäbischer Bund. The Thirty Years War exposed Pfungstadt to suffering which it had only tasted earlier. In 1622 an army passed through the area leaving the town reeling under the effects of robbery, murder, and the plague. The victory of the Holy Roman Emperor and his Spanish allies over the Swedish troops at Nördlingen in 1634 produced much the same results. 7 Seven mills had been destroyed and only forty homes of the original two hundred were still inhab1table. It was not unt1l 1750 that the town could again claim close to one thousand inhabitants. 8

French and Swedish forces marched past Pfungstadt in 1645, but their departure did not bring a long perlod of relief. The outbreak of the War of Inheritance in the 
Pfalz (1688-1697) brought more French troops into the surrounding land. When Prince Eugen and his army faced the French between Mainz and Darmstadt in 1734-35, the cown once again learned a bitter lesson. 9

The people made repeated attempts to reorganize their m1lls in the peaceful interludes between 1534 and 1735 . Because of continuous, dreadful devastation, milling had declined slgnificantly by 1770 . But the old mills offered the opportunity for the introduction of other forms of production, since they provided a cheap and readily available supply of (water) power. A dye business was set up in 1767 and was housed in an old mill. Together with the Kelsterbach porcelain works, it was the flrst factory type industrial undertaking in the state of Hesse-Darmstadt. 10 From 1838 peat was cut in the old Neckar River bed which lay near the town. These activities laid a groundwork for the later introduction of other industrial developments, but the town had to walt for the leadership of Wilhelm Büchner to awaken the full industrial potential of Pfungstadt. He established an ultramarine factory in the town in 1845. Before the tumultuous year of 1848, a brewery also mored into the thriving little town. ${ }^{\text {il }}$

The revolution of 1848 had a striking impact on the Inhabitants of Pfungstadt, especlally the Jewish members of

*The brother of the writer Georg Büchner. 
the community, who had to bear the brunt of the revolution. Early in 1848, inflammatory orations plctured the Jews as the town's misfortune. When the revolution was proclaimed on March 6, the windows of Jewish businesses were broken and goods destroyed. In the weeks which followed, older Jews were robbed and molested in their homes.

The leader of the movement, Otto KInz, controlled the town by summer. He called on the cltizens to arm themselves for the revolutionary straggle at hand, which resulted in the formation of a Bürgerwehr (militia), but it did not survive long because its members were accused of having a greater interest in liqueur than in order. By the end of the year, the town's inhabitants were beginning to ignore Kinz for more productive undertakings. Kinz, who couid not reconcile himseif to the diminishing revolutionary enthuslasm of the people, made one last desperate effort to Ignite revolt when he shot a Jew on New Year's Eve, 1848/49, but was arrested. ${ }^{* 12}$

The economic tempo of Pfungstadt increased agaln after the revolution. The town was undergoing a fundamental change in its social structure. Whereas in 1775 farmers had compcsed over $70 \%$ of the population, by 1850 they represented only $40 \%$, a percentage which was destined to fall

Some of his cohorts carried out an escape plan which succeeded in freeing him. He shaved his beard and made his way to Holland on a river boat. Contact with him was lost after he reached the United States. 
further. Jobs created by the establishment of new firms also induced people to emigrate into the town. ${ }^{13}$ (See population graph p. 462 in appendix.) The face of the town was changing, as Pfungstadt began to enjoy a new role as a center of small industry.

Naturally enough, economic changes led to a change in the political forces of the town. The dominance of the farmers was broken by the growth of the power of the Handwerker (craftsman) whose influence became particularly marked after the 1848 revolution. Büchner, already closely associated with industrial life, became the first real politician in Pfungstadt. Beginning in 1850, he was elected five times to the lower chamber of the Hessen Landtag (state legislature) as a (left wing) liberal. 14 Together with the brewery owner, Ulrich, Büchner was active in the town counc1l.

Other factorles were built in Pfungstadt over the course of the following years. The match industry, in1tiated in 1853, totaled five factorles among 1ts ranks by 1874. In the year 1860, the paper Industry was founded in Pfungstadt. The first factory employed seventeen workers and was followed by two more ventures. The most $1 \mathrm{~m}-$ portant undertaking to open its doors for business before the turn of the century was a tannery which employed over one hundred and fifty people by 1880. The money eminating from the upswing in business was deposited in the bank 
(Volksbank) set up in 1863, whlle the townspeople read news of their town and the outside world from a paper beginning In 1873.15 A veritable golden age of nometown proauction had swept Pfungstadt after 1850.

Büchner's political and economlc involvement did not stop him from finding the time in 1870 to establish a private accident and sickness insurance program; to found a klndergarden, whlch he materlally supported; and to set up Red Cross socletles. He also gave his workers a percentage of his profits each year. 16

In 1877 Büchner founded the first organized political group in Pfungstadt, an afflliate of the Deutsche Fortschrittspartei (German Progressive Liberal Party). That same year Būchner was to lead his party to victory In three separate elections. First he triumphed in his quest for a seat in the Reichstag from the DarmstadtGrop-Gerau district. ${ }^{17}$ The overpowering, personal magnetism of Büchner is attested to by the poor showing of the SPD (Soc1a). Democratic Farty of Germany) in the Relchstag election, when they could eapture only seven votes. Desplte Büchner's negative vote, the anti-soclallst laws were passed. That was the signal for the town's Protestant minister, Dr. Müller, to launch a bltter attack from hls pulplt on socialism and liberalism. Müller, a member of the Stöcker movement, unleashed a discussion which raged for weeks in the local paper. ${ }^{18}$ The result of his astions 
was a massive drop in church participation by the "liberals", a practice which became customary over the years. Tuls controversy set the stage for Büchner's next triumph. He led a group of liberals to victory, over Müller and his cohorts, in a hotly contested election to the committee in charge of the local church. Finally, his party captured three of the four seats in the town counc1l. 19 1877 had proved that Pfungstadt was the domain of the 11beral Büchner.

Not only had political awareness grown in Pfungstadt; the Industrial sector had grown as well. A clgar factory began production in 1878 , and was joined in 1880 by two more firms. The brick industry, which was one of the oldest Industries in Pfungstadt-records exist of a brick works in 1582--numbered f1ve concerns in 1880. The continued development of the town into an industrial node demanded that a tie to the rallway network be establlshed with theMain-Neckarbahn which was built between 1843-46. In 1869 Büchner had introduced legislation in the Landtag to have a rallway spur bullt to Pfungstadt, backing up his motion with the offer of partial financing of the prosect; but it was 1886 before the town was Iinked to the main tracks. 20

The Relchstag election of 1881 brought a surprise. Wilnelm Llebknecht and August Bebel campaigned in various voting districts in Hessen, notably the district Darmstadt- 
GroB-Gerau. Büchner, running again as a Progressive L1beral, needed and received the votes of the SPD to win the run-off election he was forced into. 21 Pfungstadt's workers had given Liebknecht over twenty votes.

In 1884 a local affillate of the National Liberal Party was established in Pfungstadt. Wilhelm Ulrich, the owner of the brewery, was the initiator of the move, which was undertaken in anticipation of the 1884 Reichstag election, because Büchner was in poor health, and had declared that he would not stand for election. 22 He died in 1892. Ulrich was able to carry Pfungstadt, but the SPD bEcame a political factor by winning one hundred thirty-four votes. The Increase in the number of SPD voters is attributable to the intense work of a small group of men whose energetic activity culminated in the founding of an 1llegal SPD group under the cover of the singing club Llederkranz on New Year's Eve 1889/90.23 Fritz Raab, the brother of the leader of the SPD in Pfungstadt, Georg Raab, was elected chairman of the club which served as a means of distributing party information, holding meetings, and occasionally even singing. When the anti-socialist laws were not renewed in 1891, the SPD was free to come out into the open with their membership intact. In 1892 a local unit of the SPD was officlally organized, Georg Raab quickly assuming the chalrmansh1p. The Initial efforts of the SPD to win the rotes of 
the workers met with linited success, because of the lingerlng Influence of Büchner's liberalism on the relatzonship between the workers and the Handwerker. In 1890 the party polled only 257 votes, Increased its support to 282 in 1893, and made a big jump to 530 votes in 1898. In 1898 the SPD had nominated two candidates for the town counc1l, but without a positive result. ${ }^{24}$ In 1899 the SPD held 1ts first May Day celebration which featured a speech by Georg Raab. These were trying years for the SPD because each of their meetings was closely observed by the police, and they were not permitted to display any red flags.

In the last years of the nineteenth century and the first decade of the twentieth century a decline in the number of hometown industries set in. ${ }^{25}$ Büchner's Ultramarlne factory closed, and the business of the tannery declined. The workers of Pfungstadt began to travel as far away as Frankfurt and Mannheim looking for work. Pfungstadt was developing jinto a town where workers lived (Arbelterwonngemeinde), while holding jobs in the surrounding area. Desplte this development, a wave of townsponsored construction got under way. The street system was extended to the north of the town, to accommodate the Increased population; a water system was installed in 1899; an electric1ty network was begun in 1901; by 1904 a sewer complex began to creep under the streets; while in 
1907 Pfungstadt became one of the few towns of 1ts s1ze to have an indoor swimming pool. 26 The progressive nature of the cltizens of the town reenforced the image the adjoining towns had of Pfungstadt.

The SPD f1t 1tself into the picture of the town, as the ortsvere1n grew from one hundred members in 1904 to over 220 in 1907. When the SPD began to publish a party newspaper, the Hessischer Volksfreund, in the nearby town of Darmstadt in 1905, four hundred and fifty subscriptions were immediately enlisted. The Union, through 1ts education committee, fostered the growth of a library, while the sportive inclinations of the workers were taken care of by the gymnastics club, founded in 1900.27 The SPD had built a solld apparatus, which was at the disposal of the party in the elections.

The untiring efforts of the SPD were finally capped w1th success when three SPD cand1dates, Georg Raab, Phillip Gilbert, and Paul Welgel won seats on the town counc1l in 1904. But the power of the middle class was far from dead, as the 1907 town council election was to demonstrate. That election saw the building of a "Bürger Block" (Bürgerliche Vereln1gung) which waged an election campalgn on the 1ssue of the emerging workers' cooperat1ve, claiming that the creation of the co-or: would effectively

*ne-third of the town council was elected every three years before the outbreak of the First World War. 
destroy the small businessmen of the town. W1th this theme the bürgerliche defeated the soclalist candidates across t:.e board. 28

It was not unt11 1913 that the byproduct of the industrialization of the second half of the nineteenth century, the SPD, was able to regaln the momentum which they had lost in 1907. In 1913 all five of the SPD candidates succeeded in winning election to the counc1l, 29 which was then composed of S1x SPD--one had been elected in 1910-and nine middle class members.

The outbreak of the First World War effectively cut the political activity of the organized parties to near zero. Two hundred and thirty-eight members of the community pald w1th their lives for the strugjle Germany carried on. 30

The 1mpact of war wearlness and the 1918/19 "revolution" manifested themselves in the results of the 1919 electjons. The outcome of the first town council election after the war, on June 15, 1919, enabled the SPD to place elght members on the council. 31 With the cooperation of the USPD (Independent Social Democratic Party of Germany) who recelved enough votes to place two members on the counc1l, the workers controlled ten votes to only eight for the bürgerliche members of the council. This was a pattern which was to predominate until the fateful change of 1933. A pattern which was similar to tine 
SPD dominated governments that ruled Hesse-Darmstadt in cooperation with the DDP and Zentrum during the 1920's. Pfungstadt's middle class parties continued their prewar roles with the same lineup of personalities and pos1tions.

The hometown business I1fe of Pfungstadt further declined after the First World War. Three match factories closed and the tobacco business receded. The tannery had already slid from its predominate position after the turn of the century. All of the brick factories save one had closed after the war. The introduction of the production of enamel ware, cellophane, and gummed tape took up some of the slack, but more and more workers were seeking employment in the surrounding towns. ${ }^{32}$ There were no large Industrial undertakings in Pfungstadt and in terms of hometown Industry the $1920^{\prime}$ s could not be compared to the second half of the nineteenth century without coming off a distant second.

The problems facing the town were not simple. Work had to be found, food supplies acquired, and housing constructed. A step was taken to try and ease the housing shortage with the construction of the Sledlung am Mühlberg which consisted of wooden houses constructed by emergency workers, but the housing problem remalned accute. 33 The Inflation, which swept Germany after the war, complicated the efforts of the council. In splte of the adverse 
economic difficulties, the voters continued to stick with their old parties. The years 1928-33 were to test the progressire tradtions in Pfungstait and unhappily to find their strength deficient. 
CHAPTER 1 - FOOTNOTES

$1_{\text {Prof. Dr. Michel, Prof. Dr. Wagner, Schulrat } H .}$ Quehl, Bearbelter, Helmatkrrten von Hessen in Der Lebensraum des Menschen, (Braunschwe1g, 1958), pp. 1, $4-\overline{5}$.

${ }^{2}$ Friedrich Knopp, Die Geschichte Pfungstadts bis ins 19. Jahrhundert in Pfungstadt Vergangenhe1t und Gegenwart, (Trautheim, 1965), p. 28 .

3 Ib1d, p. 29.

4.

, Pfungstadt, (Pfungstadt, no date), p. 10.

${ }^{5}$ Knopp, Die Geschichte..., pp. 37-38.

Ibid, p. 32 .

7 Ibid, pp. $46-47$.

8 Ibid, p. 59.

$9^{\text {Ibld, }}$ p. 47.

${ }^{10}$ Karl Hechler, Zwel Jahrhunderte Pfungstädter Wirtschaft in $\underline{75}$ Jahre Ortsvere1n Pfungstadt, (_, 1967), p. 89 .

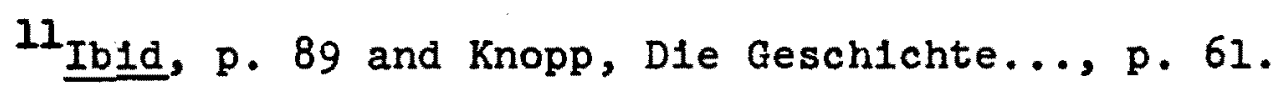

${ }^{12}$ Die Revolution 1848 in Pfungstadt in the Pfungstādter Anzelger, May 5, 1928. (This newspaper will henceforth be c1ted "TA.")

13 Hechler, Zwel Jahrhunderte..., p. 93.

14 Karl Hechler, 75 Jahre SPD Ortsverein in 75 Jahre SPD Ortsverein Pfungstadt, , 1967), p. 37 .

${ }^{15}$ Hechler, Zwel Jahrhunderte..., pp. 89-91.

16 Hechier, 75 Jahre..., p. 37. 
$17_{\text {Ib1d, p. } 38 .}$

${ }^{18}$ Ibid, p. 39 and Knopp, Die Geschichte..., p. 53.

${ }^{19}$ Ib1d, p. 39.

${ }^{20}$ Hechler, Zwei Jahrhunderte..., p. 93.

${ }^{21}$ Hechler, 75 Jahre..., p. 41.

22 Ib1d, p. 41.

23 Ibid, p. 43.

${ }^{24}$ Ibid, pp. 43-45.

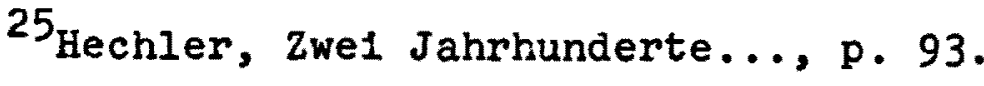

26 Ibid, p. 93.

27 Hechler, 75 Jahre..., p. 47.

28 Ib1d, p. 45.

${ }^{29}$ Iold, p. 45.

${ }^{30}$ Karl Hechler, Pfungstadt vom Beglnn des 20. Jahrhunderte bis Heute in Yrungstadt Vergangenhelt und Gegenwart, (Trautheim, 1965), p. 65 .

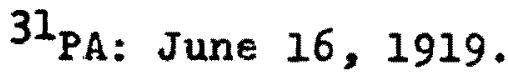

${ }^{32}$ Hechler, Zwe1 Jahrhunderte..., pp. 93-95.

33Hechler, 75 Jahre..., p. 49. 


\section{CHAPTER II}

\section{PFUNGSTADT'S STRUCTURE}

Gazing to the west from the ruins of castle Frankenstein, which is nestled in the foot-hills of the Odenwald, one can view the town of Pfungstadt. Set on the level land which stretches between the Odenwald and the Rhine River, the town stands naked in the middle of farm fields. Beyond the flelds, to the east and the north, stretch the town's forests. ${ }^{1}$ Thrusting through the middle of the scene, from the northeast toward the southwest, is the Modau (stream) which cuts directly through the middle of the old section of Pfungstadt.

Descending from the hill on which the castle is situated into the town, one encounters few homes left from the Middle Ages. One would Judge the town as an unpretentious child of several periods, but most notably the nineteenth century. In the nineteenth century the Eberstädterstrasse usurped the role of being the main dividIng line from the Modau. Running roughiy parallel to the Modau, the Eberstäaterstrasse acts as more than just a convenient division betweon the old, southern part of the town and the new, northern part; 1.t also serves as the main bustness thoroughfare, with shops of varlous kinds 
lining its sides along its path through the town. Its inherited role also stems in part from its function as a section of the highway system.

The people of Pfungstadt like to claim that they are open and friendly because of their Frankish origin. ${ }^{2}$ One would have to be a keen observer indeed in order to be able to pick out and define particular sections of the town within which those people lived, although there might be suggestions of them.

In the old core of the town around the Rathaus the majority of the farmers are located. They inhabit structures which combine a barn and living quarters in one bullding, which is surrounded by a high wooden fence and gate designed to keep animals in and unwanted visitors out.

Busirlessmen and self-employed craftsmen generally live on an upper floor above their businesses and are concentrated along and to the south of Eberstädterstrasse, to the east of the farmers. Hardly a family in the entire village could claim membership in the upper class.

The working class settled north of the Eberstädterstrasse along the streets which were lald out in the nineteenth century when industrialization swept through the town. There exist very few tenements in this area, because of the pride which was attached to having one's own 

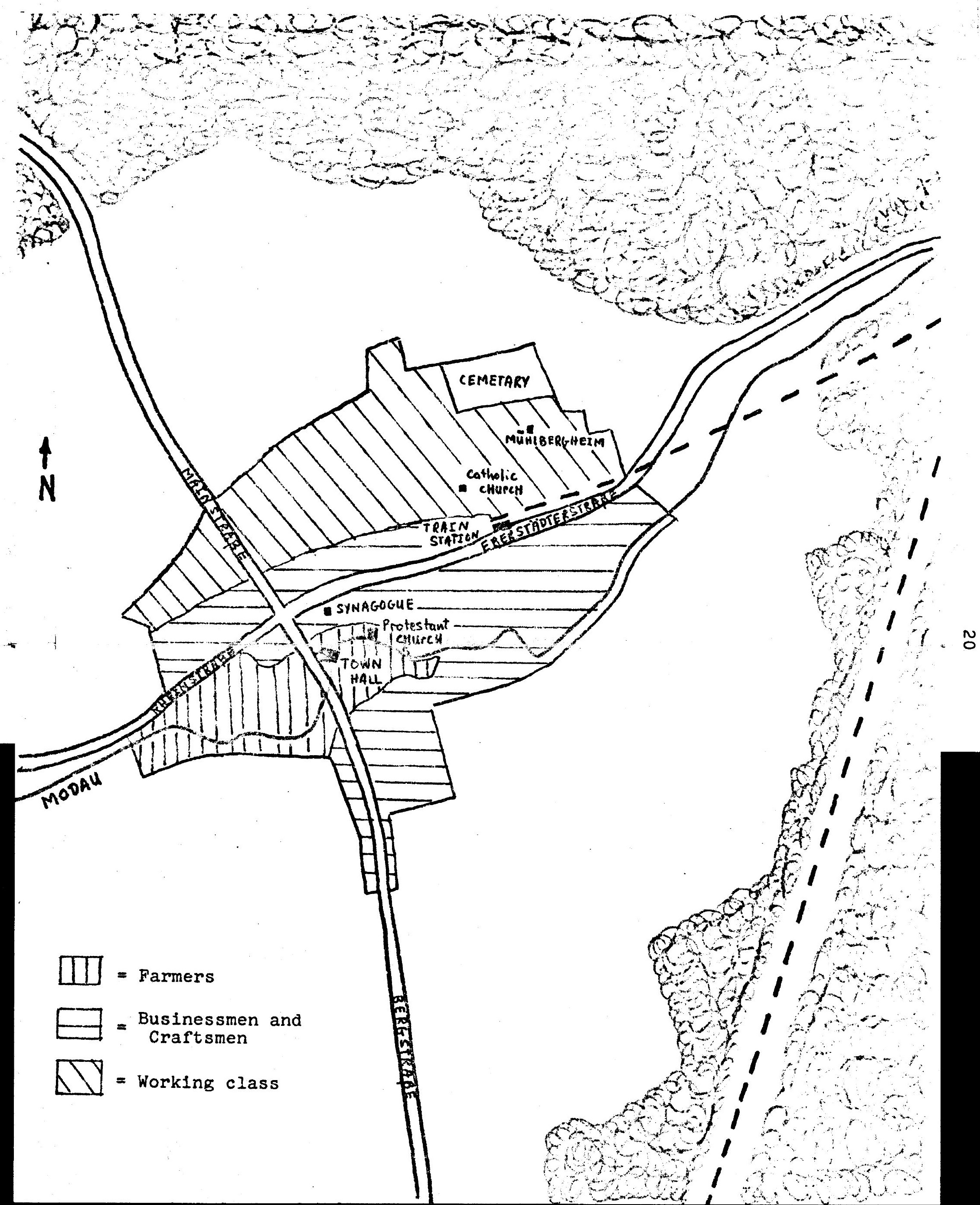
roof over one's head. The houses of the workers face directly onto the streets with a garden of some sort to the rear. Their houses were kept in better repair than those of the farmers and many of the businessmen who had inherited their homes from their fathers--homes which were normaliy bu1lt before 1850. It was not uncommon for two or even three generations of the same family to dwell in the same building on different floors.

A worker might be found to live next door to a farmer or a craftsman as another worker. No one corner of the town could clalm any esthet1c advantage over any other. There were no refugees from the heat of the summer or cold of the winter to be found in Pfungstadt.

Compared to the years around 1850 , the population of Pfungstadt had grown at a steady, unspectacular pace since the turn of the century. It stood at 7,651 by 1928-3,754 males (49.1\%) and 3,897 females $(50.9 \%) ; 4,800$ above the age of twenty-one $(62.5 \%)$, and slightly less than 2,850 people under twenty-one years of age (37.5\%). 3 The population expanded because of the 126 births which were recorded in 1928, although this figure fell during the perlod preceding 1934 to only $95 .^{4}$

A Ereat deal of pride was taken in the longevity of familles within the town, but, in fact, only six families could claim the distinction of having ancestors who lived In Pfungstadt before the middle of the sixteenth century. 5 
Many families could claim extensive numbers of relatives in Prungstadt, although most familles were united in name only. Relatives were disp?rsed $1 r_{\text {s }}$ so many different occupations that family relationships meant little more than $a$ tip of the hat or the sending of a card of condolence at the tire of someone's death.

The Inhabitants of Pfungstadt were proud of the efforts they had made to provlde themselves with housing. On May 16, 1927, there were 1,966 households in Pfungstadt. ${ }^{6} 1,819$ of these households occupled quarters which were not shared with any other family, the remainder being forced to share their quarters with two or more families. There were 1,214 inhabited structures in Pfungstadt: 584 single-family homes, and 561 buildings with two apartments, 55 with three apartments, 11 with four apartments, one with five apartments and one with six apartments. There were other "special" bulldings (1ncluding emergency housing) with ten apartments. 7 Thus there were 264.7 apartments per 1,000 inhabitants of which 21.1 per 1,000 had been built since 1918. Although 15 new bulldings with 31 apartments were erected in $1928,{ }^{8}$ there were still 158 people looking for their own apartment or improved housing. 9

Pfungstadt can look back on a long religlous history. The Protestant church was first constructed around 1300 and was enlarged in 1752. After the Reformation the 
Protestant number swelled to the 100\% mark. In 1928 the 7,651 inhabitants of Pfungstadt remained overwhelmingly Protestant: there were 7,101 Protestants (92.8\%), j21 Catholics (4.2\%), 76 Jewish (1.0\%), 153 others (2.0\%).10 Though the town was in name overwhelmingly Protestant, the presence of the minister Müller in the 1880's had turned many individuais away from the church. Only 5.1\% In 1928 and 5.2\% in 1929 attended church reguiarly--one of the poorest church attendance recoras in Hessen. 11 As one older farmer sald: "I only attend church at conflrmations and burials, ctherwlse I am not interested. No, I do not desplse the church; we simply do not go out of tradition." 12

The movement of Catholics into the town was very slow. It was not until 1912 that a Cathollc church was erected. However, this church was not staffed by a resident priest as the Catholic community was still very smal1. 13 A priest from the neighboring town came on Sundays to say hass.

The Jewlsh families of Pfungstadt could all claim years of membership in the town community. They attended a small synagogue. A well respected Jewlsh boarding school was also operated from 1854 unt1l 1906. Generally the Jews were small businessmen, accepted into Pfungstadt's middle class soclety, suffering the same economical fate 
as the rest of this class of people. These circumstances probably account for the fact that the NSDAP did not hold any meetings between 1928 and March, 1933, in wh1ch the Jewish question was the center of discussion. The general opinion of the entire population was that the Jews of Pfungstadt were well integrated into the soclety. 14

Pfungstadt's prosperity depended upon small industry. The 1934 population, according to 1ts industrial production, can be divided as follows: $57.9 \%$ of the inhabitants belonged to the working class, $17.9 \%$ were selfemployed artisans (Handwerker), 13.9\% depended upon commerce and trade, 9.3\% were involved in farming, and around 1.0\% in other professions. 15

As was the case already before the First World War, not all of the workters residing in Pfungstadt were employed in local enterprises. Almost $38 \%$ of the workers were $\in \mathrm{m}-$ ployed in the surrounding towns, some as far away as Mannhelm and Frankfurt. 16

The Handwerker had inherited a strong inclination for self-employment from the late nineteenth century. There were about two hundred different Handwerker estab11shments in pfungstadt in 1928. ${ }^{17}$ mradition dictated the employment of their children at as early an age as possible, and of training their sons almost invariably in their own profession. In essence this was designed to insure the continuation of the firm and to supply cheap 
labor. In economically prosperous times the Handwerker engaged employees, but, as the depression worsened, they relled almost exclusively upon famtly members.

In 1928, twenty-one factories, which employed 856 workers and artisans were operating in Pfungstadt. ${ }^{18}$ The number of factorles had declined in the 1920's. Three match factorles had closed and the clgar industry was hurt. However, the flrms that remalned were stable enough to survive the depression.

Around one hundred twenty miscellaneous concerns supplied varlous other necessities. ${ }^{19}$ These shops and businesses were extremely dependent upor the town's workers and in constant competition with the nearby department stores of Darmstadt. When the purchasing power of the working clasis was cut, it rippled back through every shop.

The oldest group of self-employed people were the farmers. They had a flerce tradition of independence and self reliance that did not bend with the changes of the times. There were 139 farms in Pfungstadt in 1928. However, they did not resemble the sprawling farms of east Prussia at a]l. In the whole of Pfungstadt there was only one farm with more than 125 acres, one farm with more than 50 acres, 68 with 25 to 50 acres, 28 with 12 to 25 acres. Incredibly enough, there existed also 41 farms with $2 / 1 / 2$ to 12 acres under cultivation. 20 Land rented from the 
town supplemented these private holdings. The right of succession is to be blamed for the extremely small farms as well as for the fact that land holdings were scattered all over the area.

The most important crops were potatoes, gralns, and asparagus. The horse was the basic means of tilling the so1l, while cattle furnished a prime means of making profit through the sale of $\mathrm{milk}$ and meat. Poultry, along with pigs were also raised for sale. 21

Farmers were not the only people raising crops. There were over 1,185 plots being cultivated by everyone from Handwerker to workers to members of the pollce force. 22

With the help of income tax statistics, the entire matter can be put into clearer perspective. The 139 farms had a total income of RM 160,000, an average income of RM 1,15I per farm; businesses (Including self-employed Handwerker, factory owners, and commerclal establishments totaling 339) had a total income of RM 829,000, an average of Ril 2,445 per business; six "free professions" had an Income of RM 35,000; the bulk of the town's people, the

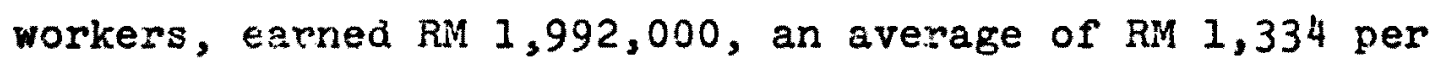
employee. 23

Savings represented a sense of seclirlty for many members of Pfungstadt's community. The only institute that accepted deposits in the general manner of a bank was the Volksbank. The bank had deposits of RM 387,275 in 
1928. 24 Besides this institution, there existed other means for saving smaller amounts of money. The SPD had organized informal Christmas savings clubs and similar organizations. The farmers also had a sort of banking arrangement, the Ralffelsenkasse, which served their purpose very well.

The social life of the town centered around the more than 55 clubs. 25 By and large, these clubs followed the political outlook and the social standing in their arrangement. A host of clubs for the workers and their famliles had a.distinctly SPD outlook, while the middle class clubs tended to fall into occupational groups with less emphasis on distingu1shing political outlooks. The KPD was the only radical group to successfully establish its own orbit of clubs. The only NSDAP clubs founded before 1933 were the Hitler. Jugend and the NS-Frauenschaft.

One of the oldest structures in Pfungstadt is the town hali which was bullt in 1614 . Within the walls of the town hall and the nearby stadthaus the affairs of the town were carried on. 26 As there were no "Land" or "Reich" offices in Pfungstadt, the number of administrators was very small. Besides the r:sual day to day business, the town provided its citizens with sewers, water, and electricity.

Pfungstadt had a tradition of good administration 
and of long years of service by its officials. Mr. Schwinn had been elected mayor in 1919 after having served the trwn a number of years as a clerk to everybody's satisfaction. 27 His knowledge of the functioning of the town administration was excellent and he was the unanimous cholce for mayor. Officially he was not affillated with any party but he often sided with the socialists.

The members of the counc1l were directly elected by the Inhabitants of the town every four years. The counc1l subdivided its authority into committees. The committees were: Bullding comittee, Electricity committee, Swimming pool committee, Land committee, Finance committee, Cemetery committee, Forest committee, Welfare committee, and School committee. ${ }^{28}$ This system enabled the elected members of the town council and the two voting administrators, Mayor Schwinn and Vice-Mayor Welgel (SPD), to supervise matters easily. Members of the council were elected to the committees proportionate to their strength in the council.

Fron 1919 unt1l 1928 this system of government functioned fairly smoothly. The council was the focal point of local action, and, as such, the members of the counc1l received great respect from the members of the communtty. Although they were not pald well, they served the interests of the groups which had elected them as well as the general 
welfare of the town in an orderly fashion.

The principle income of the town of Pfungstadt came from the following sources: Rent from town housing (RM 31,000); rented land (RM 12,800): Income from the forest (RM 43,746); return of Re1ch taxes (RM 68,300); and f1nally various apportioned" city taxes (RM 153,144).29 In normal economic times these sources of income were secure. However, if a signiflcant proportion of the taxpaying public, the working class, was removed from the tax foles, then a larger percentage of the burden would fall on the shoulders of the remaining tax payers--the businessmen. This is exactly what occurred during the period of unemployment.

During the entire perlod of the depression the town debt was lower than it had been on the eve of World War I. In 1914 the town had had a debt of RM 827,578.95 because of the bullding of a new school, swlmming pool and the construction of the sewer, water and electricity systems-all necessary 1tems in the minds of the populace. 30 In 1928 the town had a debt of only RM 613,889.21 (which increased to RM $774,042.09$ in 1931). 31 During the eariler perlod the debt had produced some noticeable results, whereas this did not seem to be the case during the depression. (See graph on public debt in Pfungstadt in append1x, p. 466.) 
Unemployment was not a new phenomenon in Pfungstadt. People had experlenced 1ts effects before. In 1928 around f1fty people (see graph of unempicyment in appendix) were supported by the town on 1ts welfare rolls, a figure that required the outlay of only RM 25,583.65 per year. 32

The town also administered a school system, the first four grades beling the Volksschule, and then the Realschule. Pfungstadt did not possess 1ts own Gymnaslum (nigh school)--the ch1ldren had to go to Darmstadt to recelve a higher education if so desired. 33 The first grade schocl was bulit in the year 1883. Before 1857 chlldren had elther been educated by a minlster or not at all. Pfungstadt was a progressive town when it came to moving with the age, and in 1907 a new school was bu1lt, providing space for the increasing student population. 34 (See graph of school population in appendix p. 467.)

The complexity of the 1ssues and the size of the stakes demanded that people organize themselves into political groups. By far the best organlzed group was the Soclal Democratic Party of Germany--the SPD. Through long years of struggle the party had become the most formidable political group. The SPD was primarily concerned with the interests of the workers. Most workers belonged to union groups, and the Gewerkschaftkartell was the organization drawing together representatives of the various groups: 
construction workers, printers, rallway workers, metal workers, painters, food and drink workers, tobacco workers, carpenters, and factory workors into a group that had considerable influence on the SPD and the political life of Prungstadt. 35

The SPD was more than just a political alliance. It was almost a way of life, for there was the Frele Turnverein (a gymnastics group), the workers football club, the Volkschor (choir), the welght lifting club, the Arbelterwohlfahrt, the savings club, the co-op, and a varlety of other institutions.

The leadership of the SPD rested in the hands of capable men. The titular head of the movement was Georg Raab who had become the minlster for work and commerce in the Hessen government in 1918, serving in that position unt1l 1928.36 He was the patron saint of the SPD in Pfungstadt, an example of a simple worker who, through the dint of unceasing effort, had raised himself and the party to a position of power and importance. The leaders of the party were invariably members of the union, although not all union members were card-carrying members of the party. The leaders of all the SPD groups were a solld team. The SPD had welded a unit together of which they could be proud: a group that saw 1tself as the heir to the progressive tradition that Büchner had set in 
motion in the $1850^{\prime} \mathrm{s}$.

The SPD was not the only party that claimed to represent the interests of the workers, however. The Communist Party of Germany (KPD) grew out of the split in the SPD ranks in the late stages of the First World War. In Pfungstadt "left" wing of the labor movement had assumed the first title of the USPD, but it quickly turned to the more orthodox stream of the KPD in 1922.37 The KPD was a small, sixty-member, but very well organlzed party that was blessed by the leadership of a first class mind, Heinrich Huxhorn. Huxhorn was no stranger to the labor movement, having been involved with the SPD before the First World War. The answers to the working man's problems did not lie with the SPD, according to $\mathrm{h} 1 \mathrm{~m}$, because it appeared to him that the SPD was becoring bürgerlich, losing its Marxist character.

The credit for the success of the KPD within Pfungstadt must be given to Huxhorn. He was an excellent speaker who respected the opinions of others in a debate, but he was also an 1ce-cold man when it came to political strategy and the carrying out of propaganda. ${ }^{38}$ His iffe was the KPD which he served very unselfishly. He recognized a goal--he chose the KPD as the best party to achleve that goal.

The German Democratic Party carried on the Ideas 
of Büchner in Pfungstadt. Basically it was a composite of small Handwerker and business men who belleved in the value of a free economy art the freedom of man. Th1s party had suffered much during the twenties in Pfungstadt because its leadershlp was old. One can actually see the death of the DDP in Pfungstadt with the retirement of Christoph Hanbuch, the last representative of the party In the town counc1l in 1928.39

The successor of the National Ifberals, the German People's Party (DVP), was composed of professionals and business men of the town. The objectives of the party were to Insure the power of Germany and the continued economic growth of the country. The leader in Pfungstads was a teacher, Jullus Hofmann. 40 The party engaged in non-political involvement.

Pfungstadt had a number of farmers who did not choose to join any of the national parties. They assoc1ated themselves with the Landbund, the farmers' party. The Lancbund was basically a group that was deslgned to keep the interests of the farmens before the eyes of governmental authoritles, and to apply what pressure it could to bring about favored changes. 41 It did not so much lead as it simply existed; it rarely held political meetings and never attempted to win members of other classes to Joln 1ts organization. Its leader was Herr Jäger. 
Besides the large national parties, there existed two distinctly local parties. The first was the Handwerker- u. Gewerbevereinlgung, which saw itself not at all as a political party, but rather as an economic interest group that wanted the best for everyone. It was neither a coherent party nor a coherent group of men. It placed men up only for local election, and remained neutral during national elections. It was led by Herr Hassenzahl.

Another local group was the group Steinmetz-Martin. They represented local businessmen and manufacturers who banded together during the town councll election, partiy out of their own sense of importance and partly because they were very interested in the economic stability of the town. 42

The final group under consideration wa:s the National Soclalist German Workers Party, the NSDAP. The original member of the NSDAP in Pfungstadt was a man named Hans Otto, who was a shoe maker by trade, but disliked his work intensely. ${ }^{43}$ He was jolned in 1926 by a group of disgruntled Handwerker, and displaced workers, who set up a "w1ld" NSDAP Ortsgruppe. 44 The NSDAP had practicaliy no 1mpact on the town until 1928. Unt1l 1930 the group was unable to win more than 250 votes out of the over 3,500 cast. ${ }^{45}$ The orlginal members were very radical, attempting, before 1929, to win the workers away from the SPD 
and the KPD, seeing thatr mission as that of freeing the workers from the ravages of the Jewish international big business. 46 The NSDAP was a very small group of fanatics who were disorganized and lacked in real talent necessary to win the hundreds of votes it would take to get them into power. They were further handicapped because the town was so overwhelmingly orlentated towards the SPD. The respected members of the midale class were loath to antagonize the workers by publically proclaiming their membership in this group. The group was led by W1lhelm Grāff, a small manufacturer, who would not adjust himself to the times in which he Ilved.

Both the DNVP (German National People's Party) and the Zentrum (Catholic Center Party), major political influences in other towns, were insignificant factors in Pfungstadt.

Most often news was relayed to the members of the town by the town's only newspaper, the pfungstädter Anzelger, which had begun publication in 1874. The paper had a standing policy of political neutrality, which served to stifle potential local competitors. 47 It did not take a stand on elections. A great deal of local news was contributed by varlous parties and clubs which filed articles which were then edited to the standards that the paper felt were acceptable. ${ }^{48}$ The paper 1tself employed only one part-time reporter. Virtually every 
household in Pfungstadt subscribed to the Anzelger.

The SPD published a newspaper in Darmstadt called t:.e Hessi3cher Volksfreund, which was distributed almost exclusively among the members of the working class. It relied upon the secretary of the SPD group to communicate news about events in Pfungstadt which were then published in a special column for local news. The paper was a part1san SPD paper which falthfully reported the news as the SPD saw 1t.

Life is made up of more than just statistics; it is In large part a reaction to events by the fixed prejudices which we have labeled as our 1deals. The history of Pfungstadt provides one example of the growth of prejudices which destroyed the basic Ideals of human existence. 
CHAPTER II - FOOTNOTES

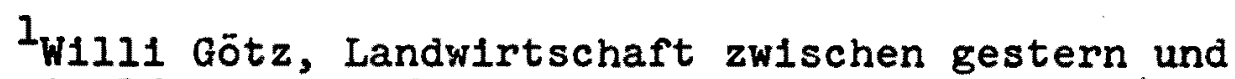
morgen in Pfungstadt Vergangenhe1t und Gegenwart, (Trautheim, 1965), p. 117 and $P A$ : January 11, 1928 .

'Interview with Maria Schulz.

${ }^{3} \mathrm{PA}$ : January 2, 1929 and population records from the town's archive.

4PA: January 2, 1929, January 3, 1931, January 2, 1932, January 2, 1933 and January 2, 1934.

$5_{\text {Friedrich Knopp, Die aeltesten Pfungstaedter }}$ Familien - elne bevölkerungsgeschichtliche Betrachtung in Pfungstadt Vergangenheit und Gegenwart, (Trautheim, 1965), p. 122 .

6PA: July 12, 1928.

7 Ibid.

${ }^{8}$ PA: June $14,1929$.

${ }^{9} \mathrm{PA}:$ May 6, 1930.

10 Records supplied by the town official Phillip Hanbuch.

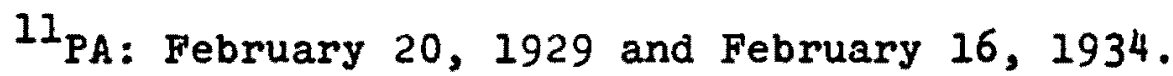

${ }^{12}$ Interview with Ludwig Gunkel.

${ }^{23}$ Hans Haßlinger, Die Geschichte der Katholischen Kirchengemeinde in Pfungstadt Vergangenhelt und Gegenwart, (Trauthelm, 1965), p. 115.

${ }^{14}$ Interviews with Adam Ruckelshausen, Jullus Winkler, Ludw1g Wenz, Johann Kölscin, Jacob Hanbuch, August Hechler, Fritz Feldmann and Jullus Hofmann.

${ }^{15}$ PA: JuIy 3, 1934. 
$16_{\mathrm{PA}}$ : June $5,1928$.

17 From the flle of Heinrich Huxhorn, interview with Karl Hechler (no relation to August Hechler) and $P_{n}$ : March 14, 1930.

18

PA: October 22, 1929.

${ }^{19}$ From the private file of Helnrich Huxhorn, Interview with Karl Hechler and PA: August 23, 1930.

${ }^{20} \mathrm{PA}: \operatorname{March} 14,1930$.

${ }^{21}$ Götz, Landwirtschaft zwischen..., pp. 179, 181 and PA: December 6, 1928.

${ }^{22}$ Götz, Landwirtschaft zwischen..., p. 184.

${ }^{23} \mathrm{PA}$ : January 12, 1930 and March 14, 1930. yearly)

24 PA: April 27, 1928. (A balance sheet was issued

25 stadt, 1970), pp: $\frac{\text { Verelnverzelchnis }}{1-14 \text { and a count of the clubs appear- }}$ ing in the pfungstädter Anzelger during 1928 and 1935.

${ }^{26} \mathrm{PA}$ : March 15, 1930.

27 Interviews with Georg Liebig, Peter Crößmann, Wilhelm Kaffenberger, Georg Herth, Heinrich Sand and Jacob Brauer.

${ }^{28}$ PA: January $7,1930$.

${ }^{29}$ Rechnung über E1nnahme und Ausgabe der Gemelnde Pfungstact für 1928, pp. 41-50.

${ }^{30}$ Copy of a letter sent to Just1zrat Maetz of Darmstadt concerning the Evangelische Kirche Pfungstadt gegen Gemeinde Pfungstadt, Pfungstadt, 9 Februar 1932 in the town's archives. 
${ }^{31}$ Rechnung über Einnahme und Ausgabe der Gemeinde Prungstadt für 19 $19 \overline{1}, \mathrm{p}$. 157-160.

32 Rechnung über Einnahme und Ausgabe der Gemeinde Pfungstadt für $\underline{1928}, \mathrm{p} .96$.

$33_{\mathrm{PA}}$ : March 3.1, 1928.

${ }^{34} \mathrm{Karl}$ Hechler, Zur Geschichte der Pfungstädter Volksschule in Pfungstadt Vergangenhe1t und Gegenwart, (Trauthe1m, 1965), p. 91.

35PA: July 30, 1932.

${ }^{36}$ Karl Hechler, Pfungstadt vom Beginn der 20. JahrHundert bis Heute in Pfungstadt Vergangenhe1t und Gegenwart, (Trautheim, 1965), p. 68 .

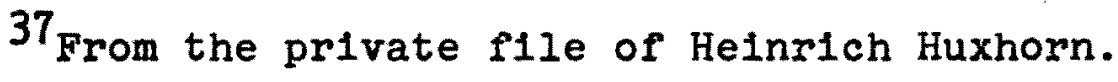

${ }^{38}$ Interviews with Peter Crößmann and Georg Herth.

${ }^{39}$ PA: December 20, 1929.

${ }^{40}$ Interviews with Julius Hofmann and Jacob Brauer.

${ }^{41}$ Interviews with Ludwig Wenz and Ludwig Gunkel.

${ }^{42}$ Interview with Adam Ruckelshausen.

${ }^{43}$ Interview with Heinrich Sand.

44 Notes from the private file of Hans otto

${ }^{45} \mathrm{PA}$ : June 1, 1928 and November 19, 1929.

${ }^{46}$ Notes from the file of Hans otto and Interviews with Heinrich Schaffner and Wilhelm Kaffenberger.

${ }^{47}$ Intervlew with Gottfried Helene.

${ }^{48}$ Ib1d. 


\section{CHAPTER III}

THE REIGN OF NORMALCY - 1928

The tensions, cracks and polarized political atmosphere of the first three years of the 1930's had their antecedents in the prejudices people nurtured in their hearts during the 1920's. The explosive demonstration of those prejudices had to walt for the fear, which the depression spawned, to ripen fully in order to dominate the town of Pfungstadt. 1928 was a year in wh1ch the normal tensions and cracks which had existed most noticably since the turn of the century, grew in intensity, without finding a coherent outlet.

January is a cold, drab month, filled with elther rain or snow for most of its thirty-one days. ${ }^{1}$ For most men and women 1 t was a'time to come together within the confines of their clubs to evaluate the activities of the past year. Tradition dictated that as many groups as possible stage a dance or other event in order to dispel the monotonous winter months. The SPD members of the community did not have to wait for spring to increase the temperature, for on January 10, the NSDAP held one of its rare meetings in Pfungstadt. On blood red signs which appeared in several places throughout the town, the NSDAP 
provocatively challenged the workers to "force the bosses to attend the meeting." 2 Despite the effort to implicate that the leadership of the SPD and KPD was unresporisive to their needs, the working class of the town did not respond to the NSDAP. They demonstrated, in this instance, a trend which was to continue until the fateful year of 1933, when the NSDAP seized power and forced the workers to join its own organizations.

Although the NSDAP saw its primary purpose would be to breach the strong position of the workers, they did not forget the middle class. On January 25, a small article appeared in the Pfungstädter Anzelger, under the title "Middle class, protect yourself!" The article outlined the necessity for a new political group which would put a stop to economic suffering, substitute action for the slogans of the large parties, and vigorously fight to protect the interests of the bürgerlich (middle class). ${ }^{3}$ With the words "the middle class becomes consclous" (der Mittelstand findet sich) the NSDAP proclaimed its establishment in Pfungstadt. This was quite an accomplishment for the local group, since it had held its first pubilc meeting on April 7, 1924, under the direction of the future Gaule1ter, Jokob Springer, ${ }^{4}$ and did not number more than ten Individuals as members in 1928.5 Between 1924 and 1928 the SOAP had held meetings 
or evening discussions very infrequently, and had had no real impact upon the political atmosphere in Pfungstadt. 6 With the exception of the Ortsgrufpenleiter, Wilhezn Gräf, the inftial standard bearers of the party did not present an inspiring picture to the general populace. They were men who were dissatisfied with their occupations and achievements and who were more eager to discuss an Issue with their fists and elbows than with their intellects. Most citizens ridiculed and shied away from them because of their drinking and radical expressions. 7

The SPD membersinip could take the recriminatory remarks of the NSDAP in stride, because they possessed a large reservolr of self-confldence. Fritz Raab, the chairman of the SPD party, proualy pointed out at the yearly general meeting in early February, that, although some younger workers had falled to join the party, the membership had continued to grow at a stable pace. Dismissing the Nazis by saying that "Nothing is so stupid that it won't find an audience," Georg Raab warned the assembled throng that 1928 promised to be a year in which the party would have to watch out for the polsoning of the political atmosphere by the middle class. ${ }^{8}$ Any realistic chance of the NSDAP driving a wedge between the leadership and the foot soldiers of the party was dispelled when the membership reelected their leaders to another year in office. 
On the opposite side of the fence was the local KPD group which busled itself with monthly meetings and comminist study discussions almed exclusively at the working class, The KPD never ventured into the general market place of middle class public opinion to try to win converts. 9 Armed with the notion that they had inherited the mantel of the pre-war "revolutionary" SPD, which they admonlshed would never had submitted to the demands that were accepted by the post-war bürgerliche leaders of the $S P D$, they campaigned for the establlshment of a soviet style government. The KPD lost no time capitalizing on the popularity of the film "Black Sunday" (about the January 9, 1905, revolution in Russla against the Tsar), 10 which was shown on February 16, while scheduling a meetIng for February 28 , to which the workers were invited to come and hear a Comrade Overhagen tell about his experi:ences in the USSR. Since the KPD considered the Soviet Union its natural ally, they tried to counteract any reports of their friends' suffering and misery. Overhagen, 1t was proudly remarked, gave a full-blooded presentation of the joys of life in the USSR, without cluttering up his speech with the usual "cy statistics".11

The 1mmediate effect ot such pro otions was not overwhelming, but the KPD had set another bud on the growth of its stem which was to bloom out into wide 
paths of influence when given certain hot house assistance. Ordinary citizens did not fear them or their vaunted revc Iution in $1928,{ }^{12}$ although many people allotted them no higher than third class citizenship. ${ }^{13}$

On March 4 the town celebrated the annual "Day for the Remembrance of the Fallen Soldiers." The proceedings were supervised by the only local veterans' society, the Krieger- und Militärverein. This organization, founded after the Franco-German War of 1870/7I, numbered the few living veterans of that war and some recruits from the men who had served in the First World War among its ranks In 1928. Because of the diverse political allegiance of its members, jt remained politically neutral until after March, 1933. 14 The lack of any organization for veterans of World War I and any militarily orientated group other than the Krleger- und Militärvereln, ${ }^{15}$ symbolized the level of effectiveness of the siren calls of chauvanistic speakers in Pfungstadt. The middle class members of society were not abnormally opposed to the values that Germany had supposedly carried onto the eastern and western fronts during the war. They simply did not focus much attention upon them, preferring to mourn their loss$e s$ in the solitude of the hearts. 16

Minister Zinn prayed for the souls of the departed at the cemetery, while the Anzelger ran a full page 
article which concluded with the thought that "one must be true to the fatherland,"17 a conception which every lovel and group in Pfungstadt, excluding some KPD members, could ascribe to.

The thin line between chauvanism and innocent comradeship is very difficult to define. A specimen of the latter was furnished in the last days of September when veterans of the World War One Landsturmballalion "Pfungstadt" held a reunion at the Hotel Straup. On Sunday, September 30 , the group lald a wreath at the base of the memorlal to the sholdiers of the First World War in the cemetery. They then gathered together for speeches and a small song show by the Männerquartet in the hotel. 18 Over five hundred men took part in the affalr, which featured words of greeting from Mayor Schwinn. The veterans were well recelved by the entire populace, most likely because their reunion occurred without chauvanistic accolades to the might of Germany and scurrilous remarks about the republic. The Volksfreund saluted the meeting by saying that there "were no 'hurrah' patrlotic speeches." 19

Ostentatious display of old saber-rattling techniques and other forms of bluster might not have been part of the program of the Kreiger- u. Mititärverein, but a close cousin. The fanning of xenophoblc coals, 
which smoldered in the hearts of some members of the community because of the French occupation of German territury which extended into the most westerly holdings of the town, was a component of the DVP (Deutsche Volks Parte1 German People's Party) program. The announced topic for their assembly on March 18, which was to include a show of slides, was "The 1000 year French pollcy of the robbery of the Rhine." 20 The general secretary of the DVP in Hessen, Welkaw (Darmstadt) chaired the gather1ng, which was described as a dignified protest against the French. 21 Disentangling the consequences of the DVP shibboleth from typlcal love of country, which all of the middle class was ready to demonstrate, is made somewhat easier by the statement of another leader of the DVP, Hen Brauer. He felt that the French occupation had little influence on the political infighting in Pfungstadt. 22 substantiating his claim, but in a modifled manner, was the assertion of an early member of the NSDAP, who sald that while he himself feared the French, there was no political polarization in the town because of the issue. 23 since the SPD newspapers are vold of a reference to the importance of such a dispute, and Herr Hechler, the leader of the SPD after 1931, could not remember any struggles of the point, the writer concludes that the issue was not an overly important one. 
Life in 1928 was not one long crisls. There were a number of diversions for the populace including entertainment at three movie theaters, the winter concert of the Mus1kvere1n, featuring a twenty-man orchestra, and even a circus which passed through the town over the Easter holldays. 24 Political and economic Instability had not become part of the dally fare of the people. There was still time to consider life in general over a liter of beer in the company of friends without the constant infection of somber notes of discord in the conversation.

The normal development of dally events was not disturbed by the SPD election planning comittee meeting on Apr1l 19 signaling that a new politlcal campalgn was in the offing, without setting in motion the "hupla" that surrounded the weeks before the vote. As was the SPD custom, public meetings were scheduled only in the last weeks preceeding the election. The all-encompassing network of worker sponsored clubs, groups, and clrcles of friends sufficed to pass along any necessary information before oper gatherings were held.

May was traditionally begun by the Union's celebration of May Day. Theoretically the workers gathered together to reaffirm their unity, strength and desire for soc1al1sm. May 1, 1928, was not dissimilar from other May Days. A parade wound its way through the streets of 
Pfungstadt ending with a speech praising the future of socialism in Germany. 25 The festivities were under the direction of the Union, not the SPD 1tself, althougn for all practical purposes they were the same. The subtle distinction between the sponsorship of the day by the union or by the SPD allowed the KPD to instruct its members to march with their respective colleagues. This was Important for it served to give the workers the feeling that despite their political differences there remained a bond of unity weaving them together.

The KPD had three representatives within the governing board of the united union, who exerted a perceptible, but limited, influence over the entire union. 26 The membersh1p of both groups anticlpated that the cords that bound the two groups together in the union could only be broken by force, 27 which unfortunately proved to be fine in theory but poor in practice when the strains of the depression revealed the full extent of the differences which lay in the path of workable understandings. In 1928 1t was normal for the workers to present a united front on at least one day of the year.

The first SPD public meeting was held on May 9 in order to take advantage of the momentum the May Day activItles had generated. The toplc for alscussion, "The meanIng of the Relchstag election for the younger generation", 
was designed to meet the effort of the party to acquire a larger number of younger members with its election campaign. 28 Coupled to the venture of SPD was the attempt of the SAJ (Sozlalistische Arbeiter Jugend - Sociallst Worker Youth) in April to recruit more children to its program. Chlldren who wanted to taste the beauty of nature by hiking and camping in the area surrounding Pfungstadt were invited to join, but the main thrust was almed at the sons and daughters of workers. 29 The SAJ was the only youth group of any importance at the time. There were groups for boys and girls sponsored by the protestant church, but their membership was miniscule. The chlldren of the middle class were without any clubs of their own, while their parents even frowned upon their membership in the SAJ for soclal and political reasons. 30 The middle class divided its loyalty between a variety of nationally powerful parties, with marginal representation going to smaller splinter parties. A small political group was not at quite the disadvantage in establishing an aura of success as might at first be imagined, since there was no meeting hall or restaurant with a large capacity in Pfungstadt. A case in point is the selection of the restaurant "Zum Goldnen Lamm" by the

* The leadership of the SPD reasoned that they would need to rent the three largest hells 30 barely accommodate the1r ent1re membership at one time. 31 
Volksrechtspartel (People's R1ghts Party). They knew full well that they could report a standing room only crawd for the speech of Professor Axt about "People's rights in relation to the right of capital." 32 The evening consisted of the professor cleverly playing on the fears of the 1922/23 inflation victims to drive his points home.

Another group which had to be counted among the splinter parties in 1928 was the NSDAP. The local members had been Inactive since January. On May 11 the Anzelger carried the notice that the NSDAP would hold an election meeting on May 12 to which the entire population of the town, but specifically excluding the Jews, was invited. 33

Whereas the KPD and SPD members had stayed away from the NSDAP meeting in April, the workers, especially the KPD, decided to attend the meeting to confront the NSDAP. The topic for discussion was to be "The deception and betrayal of the working class by the SPD". A large crowd was on hand when the meetir: opened, but did not listen to the words of the speaker long before shouting and cat-calls began to fill the restaurant, although no flghts broke out. As at most assemblies, a period of discussion was flnally allotted toward the end. Heinrich Huxhorn (leader of the KPD) was in the middle of an emotional rebuttal, when a beer glass came salling across the room 
toward him. It was enough to spark a pushing and shoving match which did not develop into a full-fledgéd confrontation because the local police stepped in and closed the meeting. 34

$\because \quad$ To insure the tranquil departure of the NSDAP members from the towns of Darmstadt and Worms, who were in Pfungstadt to bolster the small number of local NSDAP members, the police directed the NSDAP to take a back street to the train station, fearing that otherwise v1clous rlots might evolve had the group taken the main street (Eberstädterstrasse) through the town. Unfortunately, however, the atmosphere was already too highly charged. As the NSDAP people moved off toward the station they were shadowed by a contingent of KPD members. The two clusters traded Insults as they advanced up the Kirchstrasse unt1l they neared the school where they began a I1veiy exchange of blows. The NSDAP retreated in the Schulgässchen which they could easily blockade because of 1ts narrowness, One of the men in the ranks of the NSDAP recelved a blow on his head which caused him to fall sideways into the NSDAP man, Melk. He became alarmed at the situation with the result that he thrust his knife into a man who moved toward him yeling, "Heil Hitler."35 The man turned out to be HeInrich Kottman, a printer and a Hitler Youth member who was given first aid in Pfungstad, transferred to Darmstadt, and there he died the 
next day.

Melk, two other NSDAP members, and a number of KPD people, among them Huxhorn, who was charged with inclting a rlot, were arrested. Pollce searched the scene of the altercation and found $a$ knife and a gun. ${ }^{36}$

The incident, which took place on a Saturday, was not reported in the Anzeiger and the Volksfreund unt1l Monday since no Sunaay editions were published. The SPD thus found time to amend the topic of their May 14 meetIng to include a discussion of the Kottmann adventure. 37 Georg Raab opened with a warning to the crowd that they should not expect anything different from the NSDAP since they were a reactionary group, not interested in the promotion of the rights of the working class. Then he called on the people of Pfungstadt to support the SPD in the coming election so that the "foes of freedom" would be rebuffed. His remarks were followed by a discussion. Dr. Strecker (Berlin), who had been scheduled to present his thoughts on "The Relchstag election and Soclal Democracy," amended the thrust of comments to point out that election took on double importance: soclalism had to win and Nazism had to be defeated at the polls. Following a screening of the $f 11 \mathrm{~m}$, "Deln Schicksal", and songs by the Volkschor the meeting was adjourned. 38

Besldes an angry exchange of vindictive letters 
between the KPD and the NSDAP in the Anze1ger the streets were quiet. The quiet hid the commotion that churned, nevertheless, through the populace. People argued the merlts of each side's guilt in arguments in their homes and in restaurants w1th several key results. The NSDAP refralned from using Kottmann's death for propaganda purposes because of the uncertainty surrounding the event, but they did win the financial support of some members of the community; 39 support that was not openly bandied about. The hidden sustenance which the party recelved was to become one of the main reasons for the rise and eventual trlumph of the NSDAP in Pfungstadt. Membersh1p in the party was not openly declared because 1t was feared, and rightly, that the working community would refuse to purchase goods or services from anyone who acknowledged party affiliation. 40

A spate of party advertisements appeared in the Anzelfer in the last days before the election from all of the parties. The KPD exc1tement did not die down but instead found an outlet in a public meeting on May 18. Huxhorn took the opportunity to blast the tactics of the NSDAP, and call upon the working class to unite behind the KPD to defeat the fascist menace. 41 The NSDAP's presence In Pfungstadt had the not-tco-linpredictable effect of spurring the KPD on to a much more radical position. 
On the morning of the election, May 20, music groups representing the KPD and the SPD paraded through the streets of the town endeavoring tc drum up support. Notwithstanding the music, the vast majority of the voters (70\%) went to the polls between two and five in the afternoon after they had finished the1r noon meals. 42

When the results of the election were made known the following day, almost every party had something to smile about. The chlef victor was the SPD which picked up almost 300 votes to raise 1ts total to2,119 votes (51.07\%). The NSDAP, entering its first election in Pfungstadt since 1924, made a respectable showing with 260 votes $(6.26 \%)$. The number of votes going to the middle class parties remalned above 1,400 , so that one can conclude that the bulk of the Nazl vote came from people who had falled to previously go to the polls. The percentage of citizens using their right to vote swelled from $77 \%$ to $88 \%$ in the election. ${ }^{43}$ The KFD plcked up sixty-four votes, not suffering any from the taint which surrounded Kottmann's murder.

A breakdown of the 1,075 people who did not vote, but were eligible to vote, requires some examination. Division of the people by age yields the following information: 


\begin{tabular}{ccc} 
AGE & $\begin{array}{c}\text { ELIGIBLE } \\
\text { NON-VOTERS }\end{array}$ & PERCENTAGE \\
\cline { 2 - 3 }-25 & 240 & 22.3 \\
$26-30$ & 161 & 15.0 \\
$31-35$ & 115 & 10.7 \\
$36-40$ & 76 & 7.0 \\
$41-45$ & 66 & 6.1 \\
$46-50$ & 55 & 5.1 \\
$51-55$ & 85 & 8.0 \\
$56-60$ & 59 & 5.5 \\
60 and over & 218 & 20.3 \\
& 1,075 & 100.0
\end{tabular}

Men numbered $380(35.3 \%)$ and women $695(64.7 \%)$ of the group. 44 Supplementing this data is a comparison of the 1928 return by the sex of the voters. Interestingly enough, each of the old, established, non-radical parties, Including the SPD, DNVP, Zentrum, DVP, DDP, and the Landbund, obtalned a majority of their support from women. Both the KPD and the NSDAP, the parties most closely assoclated with radicailsm in the minds of the populace in 1928, recelved a majority of their votes from men. In the case of the KPD, $63.59 \%$ of its votes were cast by men, and in the case of the NSDAP, 56.15\%.45. (See appendices for a complete breakdown, p. 460.) One can loglcally conclude that more (young) women turned up at the polls than men, but that they most likely voted for the stable par $\$ 1 \in s$ 
which represented the order they deemed essential. It would seem plausible to assert that the men who entered the election polls in 1928 probably voted overwhelmingly for the NSDAP.

The soothing strains of the music of the Musikverein introduced the month of June to the inhabitants of Pfungstadt. The notes from the orchestra could not mitigate the rumble that came from the KPD when the Landtag announced on June 5 that they had agreed to pay the former Gropherzog thirteen million Relchmarks over a twenty year perlod. 46 What potentially should have benefited the image of the parties of the middle, rebounded in their faces. First the far right (DNVP, Deutsch National Volksparte1 - German National People's Party) Indicted the SPD for hypocracy because they had not been amenable to a payment to Gropherzog in 1919, then came the predictable onslaught from the KPD.

The KPD scheduled a public meeting for the evening of June 29, at which time they demanded to know how the SPD could have supported legislation which meant that needed social service programs could not be financed for the year.

To the working class of Pfungstadt this was a voI at1le 1ssue. It gave the KPD the possibl: to cultivate their assertion that the SPD leade: hip we far from the 
workers, and was almost middle class. As a matter of fact, the KPD propaganda which surrounded this question was credited with setting the KPD on their way to crackIng the rock-hard unity of the SPD membersh1p. 47

The KPD was not the only dissatisfled group in town. An article appeared in the Anzelger late in June which sought to outline the problems of the Handwerker (craftsmen). The article contained the usual reference to the essential character of the Handwerker to the basis of the state, and went on to develop the novel idea that, "1t Is necessary for the government to protect outmoded forms of production, namely Handwerker," because, "no one system of production should prevall in Germany." 48 One representative of this politically and economically significant group sounded a call which was to reverberate through the political system for the next five years. The proverblal butcher and baker still functioned effectively in the twentles, but the candle stick maker was simply producing a commodity whose day had passed. Actually, the candle stick maker was no longer a part of the economy, but the shoe maker and the tallor were. They were unable to compete with mass-produced items, but did not want to accept the change, much as the farmer did not want to. An explosive situation was growing. Significantly enough Hans Otto, the flrst member of the NSDAP in 
Pfungstadt and one of its most vocal adherents, was a shoe maker.

An ominous outpouring of militancy eminated from the town's farmers who bitterly gazed at the disintegration of thelr customary role in soclety. The Landbund, a farmers' economic interest group which posed as a political party, sponsored a rally in Darmstadt designed to place their complaints directly before the government. A large contingent of pfungstädter farmers mingled with the crowd to hear the double-barreled attack upon the state and national governments which the Landtag member, Glaser (Nordheim), launched. 49 He labeled as unbearable the farm program of the government, and summoned the farmers to "go back to the simple life, a life of thriftiness, fear of God, and love of work." He stopped after uttering the prophetic words, "before we go bankrupt, we will flght with all the tools at our disposal in order to protect the German farm and, with 1t, the very basis of the state." 50 An angry, confused, politically ineffectual mass of rarmers existed before the depression ever struck down 1ts first victim. As one simple farmer stated, "our debt was too h1gh, and the price for our products was too low. Why I could not even afford the immediate needs, such as shoes, for my children." 51 whe confrontation with these realities did more to cloud the line between political theorles than 
any number of abstract speeches.

Illustrative of the deep cleavage that existed between the working class ani the middle class was the fete encompassing the twenty-fifth anniversary of the Workers' Blke Riding Club which was scheduled for May 26, 27 and 28. It seems that the workers' club was an affiliate of the union of bike clubs "Solidarity," while the midale class club "Union" was a member of the "German" bike clubs. The bürgerlich club was, therefore, not invited to the anniversary as a group, although they could attend as individuals. The "Union" blasted the SPD populated club In a letter to the editor, proclaiming that, "clubs should practice sports, the political parties politics." 52 The events surrounding the anniversary went off without inc1dent. The central aspect of the entire problem was the fallure of both sides to grow out of their antiquated methods of Iabeling themselves "German" or "Worker" groups. Both sides allowed such practices to continue because they flrmly believed that they represented social and political classes which were separated by a chasm that could not be bridged--a fatal mistake.

The town council meeting of May 7 nad provided a forum for an analysis of the insecurlty which had begun to creep into the lives of some citlzens. During the meeting it was pointed out that there was an excess capacity in the construction industry, but not funds from 
private sources to supply a stimulus. The suggestion came forward that the town increase the number of low interest loans it annually granted to private individuals. 53 This suggestion began the process of defining the role of the town government in economic affairs. On the one hand the elected officials desired to provide the needed capital, but on the other hand they deeply felt that they had the obligation to balance the budget. Debt was a word which, if bandled about in a frivolous manner could cause a storm of opposition among all levels of the community. Although their fathers had gone into debt before World War one to provide the town with water, sewers, electric1ty, and the unheard-of luxury of a swimming pool, the Idea of accumulating debt to stimulate a given section of the general economy was forelgn to them. No thorough definition of the problem was possible in 1928 when the economy was still in some semblance of order, a forbidding omen for the troubled years that lay ahead.

In the town council the middle class parties were split Into five different parts, each with its own electorial program, while the working class parties were split into only two divisions. The most hotly debated issue to face the counc1i was the budget, which was drawn up and discussed in July.

Wilhelin Martin (from the local party Steinmetz-Martin) often lashed out at the policies of the SPD, accusing 
them of misusing the trust of the general populace. He asserted that the SPD furthered the interests of 1ts constituents at the expense of the gond of the entire town. 54 The proposed budget was the spark whlch had 1gnited Martin's outburst. In early July the budget had been put together by the finance committee under the cha1rmanship of the old DDP (Deutsche Demokrat1sche Parte1 - German Democrat1c Party) member Christoph Hanbuch. The occasion for Martin's inftial remarks had been the presentation of the budget at the councll meeting on July 16 . His verbal violence was rare and not particularly dangerous secause the hands on the levers of power were not those of Martin, but his older middle class colleague like Hanbuch. Thus It came as no surprise to anyone that the SPD and the bürgerlich counc1l members easily arranged compromises for the sticky points which had separated them during the first inspection of the budget. W1th their differences Ironed out, the budget for $1928 / 29$ salled through the counc1l meeting on July 23 with a minimum of dissention. 55 The writer of the article which appeared in the Volksfreund on July 25, whlch reported the passing of the budget, also took the opportunity to accuse Martin of provocative demagoguery and lack of manners. 56 such mild attacks on Martin were to be repeated over the coming years, but in a much more serious context. 
The town counc1l meeting of August 21 set the basic economic problems in clear relief. The council used the occasion to wrestle with the problem of finding work for the unemployed and debating the methods to best solve the housing situation. 57 Neither question was new to Pfungstadt, although they were slowly becoming more pressing. The readjustment, loss of hometown businesses, the economy of Pfungstadt throughout the twenties, did not spur on the town council members, especially the middle class members, to find new approaches to their problems. They seemed to function under the motto, "when in doubt, cut the budget," while calling upon the government to provide the funds necessary for them to solve their difficulties. The employment market was in a depressed state especially in the building industry. 58

The housing 1ssue was double-edged for the SPD. Most of the people with inadequate housing were SPD voters who demanded action from their representatives in the council. The SPD thus had a special interest in seeIng the construction of some sort of housing, but financed in such a manner that the bürgerlich parties could support. This delicate balancing act provea harder and harder to accomplish as time wore on.

clarifying the situation someithat is the story of the construction of Herr Ruckelshausen's private home in 
1928. When he announced plans to bulld his home he was beselged by contractors looking for work. Thanks to his sense of falr play, the project moved forward to the advantage of all concerned. He divided the work to be done on the house among different master craftsmen. The basement was constructed by one, the walls by a second, the roof by a third, the windows and doors by a fourth, and so on. 59 The men were eager for work; unfortunately there were few homes constructed during the entire year.

The spirit of accomodation which was one of the main trade marks of the SPD was flatly rejected by the KPD. They hammered away at inconsistent policies in the SPD whenever they had the chance. It was no surprise to find the KPD sponsoring a public meeting september l--a meeting called to discuss, "The SPD and the construction of the crulser." 60 The fallure of the KPD to acknowledge that compromise is a valid political art sowed seeds which were to bear bitter fruit in the years to come. The SPD did not respond to the charges of the KPD until late September, because of the strong position they held since the last Relchstag election. At a party gatherIng, the speaker, Weber (Offenbach) labeled the KPD a band of opportunistic malcontents who should be flghting the DNVP's plans for the restoration of the monarchy rather than the SPD. He was more interested in reminding the 
workers of the day in remembrance of the ant1-soclalist laws which were coming up on October 21 . H1s closing remerks dea:t with the leadership the SPD would have to exert if leglslation was to be passed which would lead to the needed improvement of soclety. 61

The workers enthusiastic reception of Heber tended to steal the SPD's non-radical political course. The radical parties, KPD and NSDAP, did not seem to be makIng a dent in the SPD or for that matter the atmosphere in the town. The NSDAP had not held another public meetIng since May, and, in fact, the members rarely showed themselves in Pfungstadt. 62 The KPD pushed their initlative petition against the cruiser in the first weeks of October, but could only collect elghty-three signatures from their constituency, whereas they had won three hundred sixty-elght votes in the May 20 Reichstas election. 63

The most impressive hollday to be celebrated durIng the month of August was Constitution Day on August 1I. Since Pfungstadt had an overwhelming number of republican political parties, every club took part in the festivities and the parade except for the Landbund and the "German" gymnastics club. 64 Three bands and two arum and bugle corps joined the parade which wound 1 ts way through the streets of the town to the small square 
In front of the town hall where the Vice-Mayor, Paul Welgel (SPD) spoke to the crowd. It was the b1ggest and best cllebratiun of the day that Pfungstadt had ever seen. 65 The festivities included commemoration of the constitution in the school. Jullus Hofmann (DVP) praised the splrit of the fest, calling on everyone to bear in mind the vallant efforts of the men of 1848 . When he was finlshed speaking, small black-red-gold flags of the republic were distributed to each student.

One of the reasons for the excellent attendance at the parade and festivities was simply the fact that most of the Inhabltants had grown up in familes in which their fathers had continually extolled the value of democracy. ${ }^{66}$ There was little reason to doubt that democracy would not survive many years in Pfungstadt if clever politiclans would balance the traditional liberal outlook of the populace with real accomplishments. The propagation of theorles was only one side of the coln, however; the practical people of the town also wanted to hear about results.

The Relchsbanner Schwarz-Rot-Gold was not active In 1928, because there was no organlzed trouble being generated by other groups in Pfungstadt. They also enJoyed a virtual monopoly position as far as the number of members was concerned. ${ }^{67}$ Albert wälke, the titular 
head of the Reichsbanner and his second in command Ludwig Clemenz, were respected members of the community. 68 They aniounced meetings at Irregular periods to reaffirm their belief in the democratic system of governinent and to try to win new colleagues. On July 8 , the Relchsbanner marched from the neighboring town of Eberstadt to Prungstadt in such a demonstration which ended with a speech. 69

The SPD had been engaged in the preparation of the 50th anniversary observation of the anti-soclalist laws. It was a festive occasion for the men of the SPD because it represented a trying but in the end victorious age. The day of the celebration began with a race sponsored by the Workers Sports Cluo which ended at the town hall. Next came a parade through the streets led by a band. It ended at Vögler's restaurant, the largest in Pfungstadt w1th its hall, where Georg Raab delivered a major address in rememberance of the past times. The final event was a free dance. 70

Both the Immense strength and some of the weaknesses of the SPD surfaced at this event. The SPD was the only political group in Pfungstadt which could look back on a struggle almost forty years old, which was a source of extreme pride to every working man. Georg Raab, one of the original SPD members in Pfungstadt, lent the local group an aura of invincibility and stableness. The chalrman of 
the party in Pfungstadt was Fritz Raab, Georg's brother, who had also been a founding member of the group in 1889 . Together with others (Karl ReiB - Chalman of the Assoc1ated Union and Paul Welgel - V1ce-mayor), they brought to the tasks of the twenties the suppositions of an earlier age. At a glance it seemed as if those suppositions were still valld, since the SPD had scored a big victory in the May Relchstag election. The leaders of the SPD were also aware of the deficlencles of the party; they had launched a program to recruit young members. The SPD was on what seemed to be the right path, their vote was growing and they commanded the largest single group of elected members in the town counc1l.

For women not caught up in the hectic struggle for power and Influence in Pfungstadt, the Frauenveretn (Womens Association) met regularly. They were politically neutral and organized to "bring the strength of people together in order to fulfill worthwhile goals and provide help to anyone, without regard to creed or political affil1ation." 71 Though their efforts to improve the lot of the disadvantaged were not always successful, they were a highly respected group. If one grew tired of trying to cure soclety, one could always join the Odenwald club. They scheduled frequent walks in the woods of Pfungstadt or the Odenwald. 72 
The principle forum for the battle of words which analyzed the adinistrative affairs of Pfungstadt was the town council. By the end of Novemoer, the middle ciass parties were issuing constant calls for more economy in the town's expenditures. Wilhelm Martin, a constant speaker on behalf of the bürgerlich, launched a campaign In the November 26 council gathering to convince the councll that the clty employees were being paid too much money. This charge brought on a cutting exchange which included several council members. Ludwig Clemenz finally clted Martin for trying to sabotage the function of the council. 73 clemenz accusation satisfied his SPD constituents, but not the middle class members of the community. They started to nurture the 1dea that the "left" irresponsibly allotted town funds that could actually be cut, thus saving everyone a portion of their taxes.

The Christmas holidays could not change the notions that had begun to germinate in the minds of many men and women during 1928. A profound incoherent bitterness lay just below the surface, comprehended by few, if any, political leaders, but with a raw potential for mutation of soclety. 


\section{CHAPTER III - FOOTNOTES}

${ }^{1}$ Dr. Xurt Schuhmacher, Das Klima in Pfungstadt Vergangenhe1t und Gegenwart, (Trauthe1m, 1965), p. 149 .

${ }^{2}$ Hessischer Volksfreund, January 11, 1928. (This newspaper will henceforth be cited "HVF.")

$3_{\text {PA : January } 25,1928 .}$

${ }^{4}$ Notes from the private file of Hans Otto.

${ }^{5}$ Interview with Helnrich Schaffner.

${ }^{6}$ Notes from the private file of Hans otto and interviews with Peter Crößmann and Julius Winkler.

${ }^{7}$ Interviews with Ludw1g Gunkel and Georg Lleb1g.

${ }^{8}$ PA: February 5, 1928 and HVF: February 2 and $7,1928$.

${ }^{9}$ Interview with Georg Herth.

10PA: February 17, 1928.

II PA: Pebruary 29, 1928.

${ }^{12}$ Interview with Maria Schulz.

${ }^{13}$ Interview with Julius Winkler.

${ }^{14}$ Interviews with Adam Ruckelshausen, Jacob Delp, Wilhelm Kaffenberger and Gottfrled Helene.

${ }^{15}$ Interviews with Fritz Peldmann, Helnrich Sand, Johann Kölsch and Jacob Brauey.

${ }^{16}$ Interview w1th Adam Ruckelshausen.

$17_{\mathrm{PA}}: \operatorname{March} 4,1928$. 
18 $\mathrm{PA}$ : September 26 and October 1, 1928 and HVF: October 3, 1928 .

${ }^{19} \mathrm{HVF}$ : October $3,1928$.

20 PA: March 18, 1928.

${ }^{21}$ Interview with Julius Hofmann.

22 Interview with Jacob Brauer.

${ }^{23}$ Interview w1th Jacob Hanbuch.

${ }^{24} \mathrm{PA}$ : March 25 and 30, 1928.

${ }^{25}$ PA: April 26 and May 2, 1928; HVF: April 28 and May 4, 1928.

${ }^{26}$ Interviews w1th Peter Crößmann and Jacob Delp.

${ }^{27}$ Interviews with Jacob Delp and Johann Kölsch.

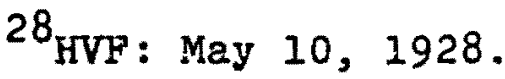

${ }^{29}$ PA: March 29, 1928.

${ }^{30}$ Interview with Georg Liebig.

${ }^{31}$ Interview with August Hechler.

${ }^{32}$ PA: May 10, 1928.

$33_{\mathrm{PA}}$ : May 11, 1928.

${ }^{34}$ PA: May 14, 1928 and HVF: May 14, 15 and 18, 1928.

35 Notes from the private files of Hans Otto and helnrich Huxhorn.

${ }^{36}$ Interviews with Heinrich Schaffner, Helnrich Sand, Georg Herth, Georg Ifebig, Julius Winkler and Jacob Delp. 
$37_{\mathrm{PA}}:$ May 14,1928

${ }^{38} \mathrm{HVF}$ : May 12 and $16,1928$.

${ }^{39}$ Interview with HeInrich Sand.

40 Notes from the file of Hans Otto.

${ }^{41}$ PA: May 18, 1928 and Interview w1th Georg Herth.

${ }^{42} \mathrm{PA}$ : May 21, 1928.

${ }^{43}$ Ib1d.

${ }^{44} \mathrm{PA}:$ Apr11 20, 1928.

${ }^{45} \mathrm{PA}:$ May 21, 1928.

${ }^{46}$ PA: June $6,1928$.

47 Interviews w1th Georg Herth and Jacob Delp.

${ }^{48}$ PA: June 22, 1928.

${ }^{49}$ Interviews w1th Ludw1g Wenz and Ludwig Gunkel.

${ }^{50} \mathrm{PA}:$ March 9, 1928.

${ }^{51}$ Interview w1th Ludwig Gunkel.

52 PA: June 2, 1928 and HVF: May 23 and 25, 1928.

53 PA: May 8, 1928 and Protokolbuch fur den Gemelnderat der Stadt Pfungstadt, May 7, 1928, pp. 101-104. (The Protokolbuch will henceforth be c1ted "PGSP.")

54PA: July 16, 1928 and PGSP: July 26, 1928, pp. 110111.

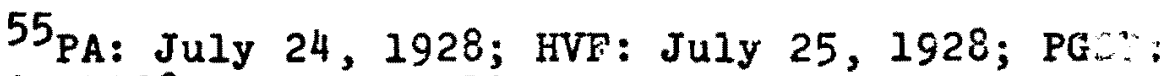
July 23, 1928, pp. 112-113. 
${ }^{56}$ hVF: July $25,1928$.

$57 \mathrm{PA}$ : August 22, 1928 and FGSP: August 20, 1928, pp. 117-118.

${ }^{58}$ Interview with Jacob Brauer.

${ }^{59}$ Intervlew w1th Adam Ruckelshausen.

${ }^{60}$ PA: September 1, 1928.

$61_{\mathrm{PA}}$ : October 10, 1928 and HVF: September 22 and 29 and October 3, 1928.

${ }^{62}$ Interview with Peter Crößmann. Crößmann claimed that the SA men changed their cloths in the woods before they dared to enter Pfungstadt.

${ }^{63_{\mathrm{PA}}} \mathrm{\text {October }} 19,1928$. Wenz.

${ }^{64} \mathrm{HVF}$ : August 17, 1928 and interview with Ludwig

65 PA: August 12, 1928 and HVF: August 14 and 22, 1928.

${ }^{66}$ Interview with Fritz Feldmann.

${ }^{67}$ Interviews with Helnrich Schaffner and Maria Schulz.

${ }^{68}$ Interviews with Jacob Delp, Jullus Winkler and Jacob Brauer.

${ }^{69} \mathrm{PA}$ : July $8,1928$.

$70_{\mathrm{PA}}$ : October 21, 1928 and HVF: October 19, 1928.

$71_{\mathrm{PA}}$ : October 28,1928 and Interview with Marla Schulz.

$72 \mathrm{PA}$ : November $6,1928$.

$73_{\mathrm{PA}}$ : November 27,1928 and PGSP: November $26,1928$. 
Mayor Schwinn's plea for harmony, whlch opened the town council meeting on January 7 , could not mask the rumblings of dissatisfaction emiting from almost every class of people in Pfungstadt. The frustration centered on the problem of money. The agenda at the January 7 meeting provides a glimpse of the primary difficulty facing people. A review of the efforts by the town to furnish work for the unemployed produced a debate in the council when the council agreed to implement a program that would increase available job openings. ${ }^{1}$ At the same time, the council pledged its continued support to the single most important Institution for the unemployed: the Winter Relief. Jullus Winkler, who later headed the Winter Relief himself, pointed out that the money and goods supplied by citizens in $1928 / 29$ winter satisfled the neads of the unemployed. ${ }^{2}$ Thus the traditional answer of town jobs and small doses of private charity seemed sufficlent to overcome the plight of the unemployed.

During the month of January varlous clubs and interest groups held their yearly general meetings. Just about every group reported that it had made some advances 
In 1928. A notable exception to the optimism expressed by many of the clubs came from the Handwerker und Gewerbevere1n (Craftsman and Business Assoc1ation). They decrled the fall of the profit level in their businesses and the high amount of taxes they were forced to pay. ${ }^{3}$ Their claims struck a sore spot in the middle class inhabitants of Pfungstadt, who thought that they had to carry the main financlal burden in the post-World War one period. The most grating aspect of the 1ssue for the najorlty was taxes. It was common to belleve that taxes were pald too often and in too large a quantitles. What they treasured most was their financial security and the satisfaction eminating from their positions. 4 The Association simply supplied one more example of the chain whlch the middle class felt was belng tightened around 1t. The allegation that the SPD-KPD dominated council was not interested in doing everything in 1ts power to correct the situation seemed very real to them.

A spokesman for the SPD shot back an answer to the charges of the Craftsman and Business Association immediately. He pointed out that Pfungstadt's businessmen lived from the wages which the workingmen earned in other towns at considerable sacrifices to themselves. He questioned the propriety of a campaign to encourage the people of Pfungstadt only to pruchase from the businessmen 
of Pfungstadt, since other towns could imftate the measures also, a potentially disasterous situation for the businessmen of the town. 5

The business community in Pfungstadt showed a very narrow conception of both the function of a market economy and their own social significance. The inflated value which the middle class attached to 1 ts standing was mirrored in the1r estimate of the "workers." A worker was not the soclal equal of the businessman according to the predominate view. ${ }^{6}$ closely paralleling the outlook of the businessman was the view of the farmers. The tenth anniversary of the Landbund on February 1 was an occasion to reconf1rm the values the members and supporters of the Landbund held to be valid. Although the members of the Landbund reallzed that they were a small group whlch could not muster the resources to institute their program on the c1ty or state level, the thought of reaching an accommodation with the SPD never crossed their minds.7

The farmers rarely reacted to any situation without gradually retreating to the notion that they represented the basic foundation of the state. Th1s current of thought found its full expression as the farmers met to prepare for the February election to the Bauernkammer. As the discussion grew more lively, the blame for the causes grew more absurd. The real cause for thelr problems, it 
was declared, was that the government had falled to focus enough attention on thelr plight. ${ }^{8}$ The only solution was for the state and national administrations to step into the breach with a program to insure the continued rentablity of their farms. The trick the farmers could never manage to master was to balance thelr demands w1th reasonable arguments which could secure them a degree of support. Because the farmers could not or would not conquer this predicanent, the SPD and the KPD felt no compunction to soften their stand against the farmers. A "traditional" battle line existed long before the disintegration ever began.

The fires of resentment may have burned brightly in the hearts of the Landbund members, but outside of the meeting hall swirled flakes of snow. The weather was particularly inciement through the first months of 1929. In themiddle of February the temperature fell to $-5^{\circ}$ (Fahrenheit), 9 but the cold weather produced its own pleasures. The frozer Rrine River acted as a magnet, attracting hordes of people to 1ts icy grandeur, so that they might walk across 1t. Da1ly demands were everywhere submerged bj the desire to take part in this once-in-a-lifetime experience. An unpleasant side effect of the weather was the curtallment of almost every construction project. This annoying fact was duly reported by the representatives of 
the construction workers, carpenters, woodworkers, and painters at the general meeting of the Union Association (Union Kartel1) later in the month. Those workers whose Jobs were not so closely tied to the weather--brewers, printers, and metal-workers announced they were fully employed. ${ }^{10} \operatorname{Karl} \operatorname{Re} \beta$, who for years had been chalrman of the Associated Unions in Pfungstadt, declared that the economy was as stable as could be expected under the prevalling clrcumstances. H1s analysis was accepted by a large majority of the attendant representatives who voted to rest authorlty in his hands for yet another year. A minority of the delegates to the meeting (KPD members) clrcumspectly attributed the problems of the workers to a scheme of the middle class to maim them, and the feeling was definitely prestent among a larger circle of workers that the middle class could not be trusted to respect the rights of the workers. 11 This reaction displayed by one section of the working class is an indication that workers were no more free from the vice of demagoguery than many businessmen.

An additional example that preconcelved notions could lead working class peofle into dead ends as easily as the bürgerlich is provided by a controversy which broke out over religion. The "Free Thinkers" reacted with overly zealous highhandedness when they discovered that their 
chlldren were recelving instruction from a teacher with ties to a church. A vitrolic articie appeared in the Arzelger which charged that the chlldren of "Free Thinkers" were systematically belng forced to study the doctrines of the Protestant Church, and were never left in peace. 12 But the charges that a protestant teacher's plot was afoot were unfounded. An amlable, if uneasy, solution was reached once the principle cast of characters approached each other long enough to reveal the true facts surroundIng the incident. When the ordinary instructor was taken 111 , a volunteer teacher for the class was required. The teacher, Winkler, took over the responsibility for the students, and taught them a number of songs which could have been construed as having a religlous overtone. ${ }^{13} \mathrm{Be}-$ yong the songs no attempt had been made to convert the chlldren in any way.

The soothing strains of the periodic concerts of the Musikverein could not hide the fact that the town council had to find work for the unemployed. Since the weather (the Rhine and Main Rivers were frozen until late in March) ${ }^{14}$ precluded the possibility that enough jobs would be found for the supply of men avallable, the town counc1l declded to handle the problem with 1ts own resources. This meant first of all furnishing the unemployed with work in the forest. At the March 11 meeting of the 
counc1l, it was agreed to employ up to one hundred men in the woods, until the middle of April, in the bellef that the econony would have overcome its normal letdown by then. In consideration of the abnormal severity of the winter, the KPD and SPD members of the council Introduced a second means of supplying work to the unemployed. They advanced the Idea that those unemployed men who were unable to find work in the forest should be given jobs in a town project to repair and extend the street system. 15 The submission of an ambitious proposal which would not yield a return on the anticipated expenditure of funds was viewed with alarm by the bürgerlich members of the counc11. 16 (The council expected a small profit on the sale of the wood which was cut and collected by the unemployed in the forest.) It was one thing to employ the unfortunate in the woods; it was quite another thing to approve a project which would not be selfsustaining. It was a revolutionary 1dea to finance such an undertaking by going Into debt, a notion which brought an even more revolting thought to the middle class members of the counc1l. Increased debt meant increased taxes, a consideration of no small Importance to businessmen who already were alarmed about the sagging economy.

Though a vote on the proposal was delayed to a later date, a hardening of positions was clearly discernible to 
the citizens of Pfungstadt. Hammering out an agreement which would accommodate the wishes of each side looked like an impossible task. The SPD and KPD, it must he added, depicted their recommendation as a temporary measure, not as a long range answer to unemployment. They were as frightened as the middle class of accumulated debt which could only be retired through higher taxes. 17

The June meeting of the town counc1l involved 1tself once again with the problem of the unemployed, who numbered almost two hundred and thirty. The SPD revived its previous ldea that jobs could be created for the men through the construction of streets. Indstead of a general commitment to construct "streets," the SPD suggested that the council focus its efforts on the path which ran between Pfungstadt and Darmstadt and was used by a number of workers to get to their employment. ${ }^{18}$ Again the SPD delegation on the council did not call for a vote on their measure, preferring to see it included in the town budget scheduled for Introduction in the July counc1l meetings. At the councll meetings of July 4 and July 11 a serious clash of priorities occurred for the first time in years. At the July 4 session the budget was presented to the members for their Initlal comments. After minor observations were expressed by several members, the mayor conflrmed the underlying conception of the entire council by declaring that 
the budget would reflect an orderly and economic state of affairs. ${ }^{19}$ The translation of these lofty objectives into cold, hard figures was to prove a tougher matter than anyone had anticlpated, especlally since the town counc1l election was planned for November, The budget debate provided the stage upon which basic party philosophies were to find their first expression.

As the budget was introduced by the finance commlttee, the counc1l. would be obliged to ralse taxes by 23,000 marks to achleve a balance between expenditures and income. When this figure was arnounced, Geme1nderat Martin Jumped from his chair to state that rather than ralsing taxes, expenditures should be cut. He advocated a measure to cut the level of spending for the school, continuIng education, and the councli's contributions to youth groups, sport clubs, and welfare outlays. He also favored Increasing the charge for water by three pfennigs and Imposing a speclal tax on businesses which operated branch offices or stores in Pfungstadt. 20 Martin's proposals were shrewdy formulated. In one fell swoop he articulated the primary economic notion of the middle class; more importantly, he assumed a position of leadership within the ranks of the middle class members of the counc1l. Martin, a nember of the local party Stelnmetz-Martin, thus cut valuable ground from under the feet of the local affillates of 
the nationally recognized middle class parties.

Vice-Mayor, Paul Welgel,(SPD), criticlzed the suggested increase in the water rate, claiming that many citizens would be unfalrly hurt because they were on fixed incomes. Speaking for the SPD, Frledrich Raab branded Martin's measures both ant1-cultural and ant1-soc1al and stated that his faction would turn them down. Martin coolly took the opportunity to hammer away at yet another point. He accused Gemeinderat Raab of being an outspoken (SPD) party man who was incapable of putting the general welfare of the town above his narrow party interests. 21 Martin clalmed, on the other hand, that since he and his colleagues were not dependent upon a national party, they could fudge the budget with unprejudiced reasonableness anà calm.

The short term degree of Martin's success became apparent when his proposals were defeated by a narrow margin. The entire budget was approved, thirteen to one, with two abstentions, indicating that the middle class councll members were not prepared to split the council Into two unreconcilable factions in 1929. Martin had scored a number of important points for his party, and from this point on he and his assoclates were conceded the role of financlal watchdogs by a large portion of the middle class, 22 an advantage sure to ald their election chances. 
The spirits of the participants at the SPD yearly general meeting were buayed up because they felt that 1928 (and early 1929) had been a productive year. ${ }^{23}$ Friedrlch Raab noted in his annual status report that the SPD had led the fight for improved housing opportunities for the poor and for the hiring of the unemployed for work in the town's forest. He commended the membership for their efforts, but warned that new struggles lay at hand. His last remark to the assembled falthfil was that he was retiring from the post of chalrman of the party after having served the SPD in that capacity since 1919. When the results of voting were announced it was determined that the chalrmanship of the party had passed to Georg Schulz. Two Intelligent young men were also elected to the governing committee of the party: Georg Llebig to the position of secretary, and August Hechler as a member at large. 24 Raab's retirement acted as a signal to the town that the orlginal troops of the SPD were ready to pass the mantel of authority to a new generation.

The new chairman Immediately set, as his primary priority, a SPD victory in the town council elections scheduled for November. H1s second goal was to continue the party's organizing work anong the young workers in the town. Planning counter measures to the propaganda of the NSDAP lay "ar down h1s list on the schedule. He was 
certainly not alone in subscribing to the Nazis an insigniflcant potential function in Pfungstadt's political affairs. The threat the NSDAP posed to the solidarity of the SPD simply did not justify a massive reaction; that the Nazis had set their sights on the fertile ground of midile class discontent was simply not discerned by the leadership and the members of the SPD or the KPD. 25

The leadership of the SPD was much more worrled about KPD inroads within the membership of its own ranks than some small pin pricks from the NSDAP. A year-old Incident provided the KPD with the spark it needed to regain momentum. On April 9, almost one year since the "Kottmann Incident" had taken place, trial of the acoused started. The nine KPD and two NSDAP men on trial were charged with disturbing the peace by the prosecuting attorney. He also singled out Heinrich Huxhorn (KPD) for the additional charge of inciting a riot. 26 The prosecutor opened the case by stating that he believed that the KPD crowd had most likely been responsible for the altercation because they had outnumbered the NSDAP. He also asserted that rocks and other objects had been thrown at the Naz1 contingent by the KPD. A series of Nazi witnesses were called who denied any clalm that they were armed with pistols or had provoked the KPD in any way. KPD witnesses declared that the NSDAP had indeed been armed, 
pointing out that a gun had been found at the scene of the f1ght the next day by the police. The reporter for the Arzelger described the statements of the witnesses as havIng done a wonderful job of "leaving everything in the dark. $" 27$

The following day the trial resumed with summations by the lawyers for the defense, both KPD and NSDAP, and the prosecution. The prosecutor demanded that Huxhorn be sentenced to an elght-month jall term for lnciting a riot, and that the other defend nts recelve four-month terms. He moved that Hans Melk, the NSDAP man who had stabbed Kottmann, be turned over to trlal in a higher court. 28

A verdict was reached by the court within the week. On April 16, the court sentenced Huxhorn and six other defendants to three months in jail for disturbing the peace. The charge against Huxhorn of Inclting a rlot was dropped, while two other men were cleared of ali charges. Melk's case was remanded to a higher court. ${ }^{29}$ The reaction of the KPD defend.nts to the outcome of the trial was swift; they retained the SPD Lawyer Sturmfels (Darmstadt) to appeal their convictions. While their appeal wound its way through the bureaucracy of the courts, they remalned free.

Almost Inmediately the Union Association 1ssued a statement deriding the court for taking the word of the 
NSDAP witnesses over those of the workers. They advocated that the court should have inspected the NSDAP members more intensely if it really wished to find the sourse of tre trouble. For the SPD, the trial could be shrugged off with frustrated references to the injustice surrounding the matter; for the KPD it was another example of the nalls being pounded into the coffin that the capitalist system intended for the workers. The KPD leadership astutely began to circulate the impression to the workers that the KPD defendants were being persecuted solely for their political theories. ${ }^{30}$ The principal means at the disposal of the KPD to combat street violence was the League of Ant1-Facists whlch encompassed both the membership and the goals of the Rotfrontkämpferbund wh1ch had been banned in the state of Hesse-Darmstadt by the interior mirister. Although the League of Ant1-Faclsts was not a large group in 1929, the estimated size was twenty men; they agltated the nerves of both the bürgerlich and the SPD regularly. 31 The questions surrounding the payment to the GroBherzog, the building of a cruiser by the Republic, the "Kottmann incldent," and finally the frustrating lack of action on the unemployment problem combined to draw new strength to. the KPD. With little reason to oppose the NSDAP (they were rarely to be seen in unfform), the KPD took to the surrounding countryside to win new converts among the workers 
and to lend a degree of support to other KPD groups which did not possess the manpower of the Pfungstadt un1t. 32 Muny a Sunday was spent on a blcycle peddling from town to town where meetings, demonstrations, parades, and occaslonal flghts took place.

To counteract the KPD propaganda the Union Assoclation stressed that the worker had to remaln united at the May Day celebration. L1terally hundreds of workers gathered early on that day to march in the traditional parade which featured two bands and a drum and bugle corps that wound its way through the streets to the sportplatz. 33 The KPD had again instructed 1ts members to joln the parade as Individuals to underscore the unity of the working class, even though the KPD leadershlp was uneasy with the programs of the SPD and the Union. At the Sportplatz the men were jolned by their familles to hear a speech by Helnemann (Darmstadt)., He declared that the power of the workers depended upon their unlty more than anything else. Disunity and a splintered approach to political questions, he sald, were the quickest way for the workers in Pfungstadt to lose their grasp on the levers of power. He closed by reminding the assembled crowd that, "all wheels stop when your strong arms will 1t." 34 But the crack that had developed between the KPD and the SPD during the Relchstag election of 1928 was beginning to spread to the 
Union because of its strong backing of the SPD proposals In the town counc1l. The KPD officials in the Union had pressed their colleagues to take a flrmer stand on the 1ssue of town jobs for the unemployed. The months before the May Day festivities had witnessed a steady growth in the discontent w1th the leadership of the Union AssociatIon by 1ts KPD members, a discontent which bordered on open revolt after May 1st. 35

While some of the citizenry engaged themselves in the political questions of the day with amazing zeal, others were content to let l1fe's disputes swirl around them without comment. The tenth anniversary celebration of the sangervereinigung (United Singing Club) Ir early June was a time for the Innocent release of accumulated energy. The Sängervere1n1gung staged a parade and fest for the people of Pfungstadt. ${ }^{36}$ The inftial revelry which began on Saturday (June 9) with a torchlight parade set the tone for the entire weekend. A mild, friendly attitude allowed particlpants and non-particlpants alike to drown the1r cares in a liter or two of beer.

One organization which earned the praise of the ent1re community was the volunteer fire department, which commemorated its fiftieth anniversary on July 20 and 21 . Following a parade on Saturday (July 20) the department put on a demonstration of f'lrefighting techniques on 
Sunday. Jullus Hildebrand, the owner of the brewery, presented a contribution of RM 2,175 to the chlef after the demonstration. 37 He nuted that the businessmen of the town realized the importance of the department and wished to express the1r appreciation for the hours of work the men put in to protect the town from the danger of fire. His comments were greeted with a round of applause from the assembled crowd. While the fire department was recelving the unanimous approval of the populace, the young people of Pfungstadt were lambasted by an older member of the community. The Anzeiger printed a letter to the editor which was designed to analyze one aspect of the problems young people presented to the older generation. The tongue-in-cheek style did not hide the writer's deadly earnestness.

We live in the age of children: We hear this from many sources and the grounds for it are covered in every magazine whose editor claims to understand anything. Bearing this in mind I must say that this precept is not taken into consideration enough [In Pfungstadt]. Let's take the Eberstädterstrape as an example. Countless motorscooter riders can be found there every evening, proving that their 'gas horses' can make an enormous amount of noise. I think that it's outrageous that the police do not close the street, lead pedestrians through the nearby side streets, and tell the inhabitants not to leave their homes between 7 and il P.M. I would call this practical cooperation with the ideal of the age of children. Who can agree with a mother who has worked hard all day when she gets excited when her child wakes up because of all the nolse. One can really not expect the maching gun like noise of the motorscooters to be turned off merely because a child is awakened. 
In this age such notions are outdated. I hope that these lines will help make the responsible authorlties more concerned about scooter riders, so that none of them have to ride through town under elghty kllometers per hour. [I hope] that all of our riotorized contemporarles are removed from [our town's] racetrack - the Eberstädterstraße. 38

This was only the tip of an lceberg of dissatisfaction with young people in general, who were accused of being irresponsible, of not desiring to save money, and of lacklng a proper respect for work. 39

Paralleling the festivities surrounding varlous anniversarles a stock show and sale was held once a year during August. The show, sponsored by the ZlegenzuchtVerein Pfungstadt, assumed an 1mportant place in the farm I1fe of the town. 40 The Handwerker also scheduled a display of their goods in conjunction with the stock show in 1929. Th1s 1dea was lauded by many people because it combined two of the basic occupations, upon which the town had grown, in one neat exhibition. From August 22 to August 25, a public auction, private trading, and public attention in the proceedings dominated the atmosphere in the town, sweeplng aslde the nagging fears which many cltizens complained about. Attendance at the show was above average, although the craftsinen complalned that people did not take thelr exhibits as serlously as they would have $11:$ :ad. 41

In the midst of the non-political activity, the 
NSDAP held its first public attempt to win new recrults to their cause in quite some time. ${ }^{42}$ The public attempt of the NSDAP to stimulate interest in the local group met with only limfted success because potentlal members felt that their businesses could not survive a boycott which might set in if the working class found out. Thus the publicly acknowledged membership of the party remained small, while secret membership in the party increased. 43 The acceptance of the party as a legltimate vehicle for the expression of the discontent and frustration among the farming community and many small businessmen had begun to grow. While the Naz1s were discovering their lack of pub11c support, the SAJ (Young Soclallst Workers) staged a county convention in Pfungstadt. 44 The Pfungstadt SAJ, as host group, arranged the entire affair with the support of the SPD, who were extremely proud of thelr youth group. But outside of the working class, the young people of the SAJ who gathered in Pfungstadt made little 1mpact on the populace.

Another Indication of the minimal impact of the Nazis in Pfungstadt was the impressive display of strength the republican forces of Pfungstadt staged on August 10 and 11 during the Constitution Day festivities. The twoday affair was easily the largest the residents of Pfungstadt had ever seen. ${ }^{45}$ on Saturday, August 10, hundreds 
of people jolned a parade whtch marched for over an hour before it reached the town hall where a local dignitary exiolled the virtues of democracy and the republic. His concluding remark that "the vast majority of Pfungstadt's c1t1zens are true to the Republic and the Constitution" summarized the situation in 1929 in Prungstadt. ${ }^{46}$ on the second day of the celebration Minister $Z 1$ n, the town's protestant minister, held a church service in honor of the Republic, while later in the day a memorial concert was presented.

As in previous years, the adult inhabitants were not the only ones to take part in commemorating the Constitution. On August 13 the school children were led by thelr teachers in a Day of Honor, whlch Included a muslcal presentation, the recitation of poems and an address to the assembled students by a teacher (StraBmann). ConcludIng the program at the school was the distribution of small flags bearing the colors of the Republic. 47

The weather did not cooperate with the people of Prungstadt at all in 1929. A cold spell had gripped the town in 1ts 1cy claws between January and Apr1l, while a heat wave cut the size of the crops during August and September. 48 Along with the damage to the crops came a putrid smell from the Modau which the Anzelger blamed on discharged waste eminating from a factory in Eberstadt. 
The paper editorialized that the town council must do something about the "stink" before the atmosphere became completely unbearable. Failing in an effort to get the offending company to clean up its mess, the paper demanded that the plant be shut down entirely. 49 The firm replied that 1t was not responsible for the pollution, but the paper stood its ground inviting the company's officials to come to Pfungstadt themselves and discover that the smell was very real.

Against this background of a heat wave and the unpleasant oder from the Modau, the election campaign rumbled to 11fe. The SPD, true to their chairman's promise to campalgn early and with vigor, Inaugurated the scramble for seats on the town council on August 31. The leadership had not forgotten the bürgerlich charges that the middle class were bearing more than their fair share of the tax burden In Prungstad. In an effort to point out that the workers were suffering more from unemployment and diminishing wages they announced that Seubert (Darmstadt) would explain to those interested, "Who carries the Debt."50 Seubert's crisp style served as a workable vehicle to convey his contention that the working class was under more pressure from taxes and unemployment, while the imagination of the middle class had produced thelr unfounded claims. His polnt fell on eager listeners, who bolstered the argument 
with lively shouts of approval. The party treasurer, K1öppinger, characterized the financial standing as outstanding. With the knowledge that the party would be able to mount a major campalgn without concentrating first on raising funds, it was decided to hold another meeting late in September and plaster the town with handbills Just before the election. 51

The NSDAP was also beginning to anticipate the town councll election when, in the second week of September, they rented 2 restaurant in which they might present Ringhausen (Offenbach). Ringhausen revealed to the smail crowd which was "exploiting the working class." 52 The lack of response from the working class was no hindrance to the party falthful who continued to plan other meetings before the November election. The spirit or the NSDAP members was neither shaken nor diminished, although no one belleved that they would make a large impact upon the electorate. 53

Several days later the Landbund held one of 1 ts rare membership meetings, this time to discuss the price of milk as well as to set the election campalgn in motion. At the meeting the farmers were more concerned with defending the two Pfennig increase in the price of milk that had just been instituted than discussing politics. ${ }^{54}$ A majority of the costs, they clalmed, were due to the hot 
speli and also to the rise in taxes which they had experienced. After a spirited discussion they agreed that the blime lay with the milk handlers. Only after the 1ssue was dismissed did they turn their attention to the election, deciding informally on a list of candidates they would place before the voters. 55

Another interesting development was the meeting of the Steinmetz-Martin during the last week of September. This was to be their only meeting before the November election, so they attempted tó set down their program with care. They declared that their main thrust in the town council would be to keep the budget within reasonable limits. 56 They also promised to forcibly represent the interests of the middle class in the face of the working class majority which they accused of irresponsible financlal activities.

Capitalizing upon the popularity they had won in the budget debate of July, the Steinmetz-Martin party reenforced their concern for the general welfare of the commun1ty. They had discovered a substantial echo to Martin's declaration that his non-party status allowed him greater latitude in arriving at sound decisions. Therefore, during the campaign they declared: "No Individual should practice volitics in the town councll, because earlier (before $19 \%$ ) the general welfare of the town was considered to be above the policles of each party." 57 
In 1929 the Steinmetz-Martin slate was primarily an economic interest group which directly fought two other parties for support--the DVP and the Craftsmen and Bus1ness Association. The DDP (German Democratic Party) did not put up any candidates for the election because of the retirement of Christoph Hanbuch from active political life (he did not run because of his age). The fleld lay open for the Steinmetz-Martin candidates to cash in some of the chips they had won in the strong stand they had made the previous July when the budget had been up for consideration. The bulk of the campaign activity they carried on was by word of mouth among their frlends and assoclates, allowing them to save money and retain their image of non-political involvement. 58

A coordinated effort was launched by the Assoclated Union and the SPD to Influence the electorate on the final days of September. First the Union met to debate the question of unemployment insurance. In a moving appeal to his fellow citizens one worker declared:

We do not want to be supported, we do not want (to be given) beggars' money; we want work, most of all, work. But if neither the Reich nor the Land nor the town can give us jobs, then at least provide us with enough support so that our families can live. 59

To begin the SPD gathering which was scheduied the right after th Union meeting, Ernst Wälke, member of the town council and the brother of the Relchsbanner leader, 
Albert Wälke, proclaimed emphatically that not one Pfennig was spent by the town in $1928 / 29$ that was wasted. Whereas the Union, the night before, had been calling for a Just level of support for the unemployed, Wälke chastisod the KFD for planting the idea among the unemployed that higher levels of support could be wrung out of the middle class. 60 The courage of the SPD to try to balance the demands of the unemployed with the ability of the middle class and the remalning workers to pay was a dangerous business. It was dangerous because both the middle class and the KPD could outbid the SPD for the alleglance of varlous groups w1th more radical suggestions than the SPD was willing to make. The struggle to retain a reasonable position in the middle of an ocean of emotional appeals was the chief problem for the SPD throughout the years before 1933 .

The SPD firmly believed that they could stem the t1de of radical, demagogic propaganda for all intents and purposes, whlch was surrounding them, by outsmarting and outworking the other parties. An appeal was put forward at the meeting for every SPD member to place himself at the service of the party during a discussion of the upcoming town council election. To that end it was agreed that the week of October 12-19 ould be set aside for an intensive campaign. After nominating candidates for the 
election, the chairman closed the assembly with the old slogan, "Mit uns das Volk, mit uns der sleg!"61 A further indiation of the stajility and integrity of the SPD is provided at the time of Stresemann's death. The Hessischer Volksfreund praised him with the words, "It Is to Stresemann's credit that he was able, in the end, to bring the politiclans of all bellefs together (under one hat)." 62 . Unfortunately, the tide was turning against the politics of reasonableness. A new chord had been struck in the hearts of the unemployed and the middle class. Unconpromising polemics were replacing reason. Using the summer months as a yardstick, the months from September to November were a highly charged political period. Complicating the political spectrum was the Craftsmen and Businessmen Assoclation's desire to place a list of its own before the public. This was done for two reasons: 1) They felt that it was necessary for them to represent their economic interests in the counc1l themselves, ${ }^{63}$ and 2) They did not desire a political alliance with another group because of Intense personal animosity which existed between the candidates of the Assoc1atic: and the Steinmetz-Martin group. Martin was a watchmaker by trade as was the chlef candidate of the craftsmen and Businessmen Association, HassenzahI. The rivalry which existed between the two men did not even bend when 
It came to the defeat of the financial policies of the SPD-KPD. 64

The DVP which had besn caught with its guard down during the budget debate in July, tried to recoup its losses by stressing that it was ready to fight for the Christian interests of the people and for a decent budget while holding down taxes if they, the voters, would support them. 65 But the DVP had a great deal of ground to gain back. Their leaders were divided on what might be the best manner in which to accomplish this task, outside of restressing their old themes. No new blood and no dramatic new strategy came to the aid of the party. 66

The Irrepressible energy of the NSDAP found an outlet on October 14 when the party staged a public meeting featuring a miner from the Ruhr who scheduled the topic: "Sixty years of work - ten years of fraud." 67 The meager forces at the disposal of the NSDAP in Pfungstadt were regularly supplemented by reenforcements from Darmstadt. October 14 was no different. Only twenty people were attracted to the restaurant, "Zur Krone" by the advertisements of the NSDAP even though the admission charge was a nominal thirty pfennigs. But thirty members came from Darmstadt. Nevertheless, the meeting was not a success. A large contingent of KPD workers milled about in front of the restaurant occasionally taunting the people inside. 
None would step into the gathering place to hear the remarks of the NSDAP's speaker. ${ }^{68}$ The caution of the KPD was born from 1ts experienues in 1928. The appeal of Huxhorn and his friends was still pending before the court and they did not want to provide the judge with any excuse to flatly refect their lawyer's motion for dismissal of the convictions. 69

The Assoclated Union and the SPD were intelifgent enough to realize that the words of the KPD, specifically Huxhorn's, were much more likely to sap their strength than the wild charges of the NSDAP. ${ }^{70}$ To meet the onslaught of the KPD, the SPD held another election meeting on October 26. During the course of the assembly, the f1lm "Vom Willen zur Tat" was shown slnce it succinctly explained the accomplishments of SPD town council members in Hessen. The entrance fee was set at a low twenty Pfennigs for the employed whlle the unemployed were allowed to enter for nothing. Besides restating the necessity for the election of SPD members to the town council, the chalrman (Schulz) Introduced two other topics for discussion. With measured words he attacked: 1) the appeal of the NSDAPDNVP for slgnatures on the1r petition for a referendum on the Young Plan which had begun on October 14. At the meeting the SPD leadership followed the same format which they had used in an article that appeared in the Anzelger on the 
same day to launch a violent attack on the Hugenbergische referendum. With the upmost severity the chalrman lashed out at Hugenberg as a man lent on destroying the composition of Welmar Germany. He gleefully announced that only eleven people had signed the petition in Pfungstadt; 2) the candidates of the NSDAP, who had submitted their lists of potential council members under the title Nationaleund soziale deutsche Arbelter- und Angestelltenvertretung. 71 Schulz blasted the convenient new name the NSDAP had given themselves as a cheap trick, a valn attempt to fool some unsuspecting members of the community, a "wolf in sheep's clothing" act which would not succeed. It was pointed out that not one worker was represented on the "new" party's list of candidates.

Easily the most active party during the election campalgn was the SPD. They held two more meetings before the November 17 vote. The first was on November 1 at the home of Paul Welgel included a discussion of strengths and weaknesses of specific candidates. The second assembly provided the opportunity for the voters to hear Mayor Lorenz (Eratrusen) discuss the policies of the SPD in the town counc1i: Between the meetings members were busy handing out leaflets and pasting placards all over town. 72 The NSDAP-DNVP petition drive ended on October 29 with a total of fifty-five signatures. ${ }^{73}$ The SPD claimed 
that the final figure had risen to fifty-five because the Landbund had stepped in at the last minute to encourage Its membess to sign the petition. ${ }^{44}$ The NSDAP looked on the drive as a success. They viewed the matter from the perspective that they were the reciplents of political support from an economically and soclally slgnificant group, the Landbund, which had been opposed to their goals to that point. ${ }^{75}$ Considering the fact that 4,893 voters were eligible to slgn the petition, the impact of the drive, purely in terms of numbers, was small. But In terms of influence won, the NSDAP drive was a qualified success. People who knew little or nothing about the NSDAP were suddenly exposed to 1t, and, while they might not have rushed into the arms of the NSDAP, they certalniy did not refect the motives of the group. After the drive, a certain respectability was assigned to the NSDAP by a growing number of middle class citizens. 76

To counteract the propaganda of the Steinmetz-Martin Group and the Naz1s, the DVP called one last meeting before the election. Somewhat confused by the skillful maneuvers of their opponents, they fell back on a traditional call for a morally high professional call of government officlals, a bellef in the values of their fathers, and more understanding for the problems of the middle class by the town counc11. 77 But they were troubled by the 
signs that pointed to a decline in their total vote before the election.

KPD campalgn activity before the election culminated In an election eve rally. At the meeting the SPD was charged with falling to do all that could be done for the unemployed. The largest part of the KPD election endeavor had been almed at dissatisfied SPD voters. Indeed, the KPD seemed much more interested in lambasting the SPD than even the NSDAP. ${ }^{78}$. Verbally the SPD took a beating from the KPD, but physically Nazis got a share also. There were no large fights before the election, but small personal altercations were often sparked by the consumption of an Inordinate amount of beer. Those fights that did occur took place in working class restaurants and invarlably involved very few individuals. 79 It is very doubtful that votes were sucked from one party to another on account of the fights.

On election day it rained continually. But the rain did not restrain elghty-six percent of the eligible voters from marking their ballots. ${ }^{80}$ Two Important developments became apparent when the election results were announced. First, while the number of SPD voters actually increased by elghty-two, the percentage of the vote they won fell by almost $1.5 \%$, while the KPD gained a significant number of new voters. The SPD, realizing what had happened to 
them, frankly declared that of the four hundred young people who gained the right to vote since 1925 less than one hundred had jolned the ranks of the SPD, whereas over two hundred should normally have jolned. They blamed this fact on the unemployment young people faced after they had completed their apprenticeships. To counteract this trend the leadership of the SPD laid plans for the Immediate introduction of a program of voter education meetings. ${ }^{82}$ second, and the most significant product of the election, was the meaningful gains scored by the

RESULTS OF THE NOVEMBER 17, 1929, TOWN COUNCIL ELECTION

\begin{tabular}{|c|c|c|c|c|c|c|}
\hline Party & \multicolumn{2}{|c|}{ Votes } & \multicolumn{2}{|c|}{ Percentage } & \multicolumn{2}{|c|}{ Members } \\
\hline SPD & 1,710 & $(1,628)^{*}$ & 42.5 & $(43.46)$ & 8 & (8) \\
\hline $\begin{array}{l}\text { Stelnmetz- } \\
\text { Martin }\end{array}$ & 754 & $(564)$ & 18.64 & $(15.19)$ & 4 & (3) \\
\hline $\mathrm{KPD}$ & 494 & $(289)$ & 12.21 & $(7.78)$ & 2 & (1) \\
\hline Landbund & 361 & $(442)$ & 8.92 & (11.61) & 1 & (2) \\
\hline DVP & 269 & $(321)$ & 6.65 & $(8.92)$ & 1 & (2) \\
\hline $\begin{array}{l}\text { Craftsmen \& } \\
\text { Business } \\
\text { Association }\end{array}$ & 251 & $(278)$ & 6.20 & $(7.48)$ & 1 & (1) \\
\hline $\begin{array}{l}\text { NSDAV } \\
\text { (NSDAP) }\end{array}$ & 206 & $(---)$ & 5.09 & $(--\infty)$ & 1 & $(-)$ \\
\hline$(D D P)$ & $(--)$ & (191) & $(---)$ & $(5.14)$ & $(-)$ & (1) \\
\hline & 4,045 & $(3,713)$ & 99.76 & $(99.28)$ & 18 & (18) \\
\hline
\end{tabular}
election. 81

* Results of the November 15, 1925 town council 
NSDAP and the Steinmetz-Martin groups. A development similar to the SPD troubles was occuring to the Landbund, and the DVP. Both parties lost a number of thelr potent1al supporters to the NSDAP. The growth of Steinmetz-Martin was most likely the result of the fact that the DDP did not enter the election. Martin's attacks on the spending hablts of the town councll together with their non-polltical cloak must have had a telling influence on the voters. And Steinmetz-Martin were well established members of the community who did not represent the radical break with the past that the NSDAP did, 83 which probably accounts for the fact that the NSDAP did not equal the two hundred and sixty vote level they had achieved in the 1928 Relchstag election.

The KPD set out immediately to capitalize on its election success. They annexed a cause with lightening speed which promised to stir up the working class and drive another wedge between the KPD and the SPD. Heinrich Huxhorn charged that the SPD would try to keep him off the town council by claiming that the election of his wife's sister, Marle Reiß, disqualified him because relatives could not serve at the same time. ${ }^{84}$ The matter seemed to have been (deliberately) blown out of proportion by the KPD leaders. The SPD never actually called for the barring of Huxhorn, 85 and Mayor Schwinn declared at the December 2 council meeting that the 
elections were perfectly legal. ${ }^{86}$ Therefore the incident is not so important for what happened, but for the mil1tancy which the KPD mantf-sted. The KPD had always rebelled agalnst the role the SPD played in Pfungstadt, but the year 1929 marked the first time that significant combination of factors enabled the KPD to make significant strides toward their goal of political power. Huxhorn's demagogic olitburst was but one more example of the most common KPD tactic.

It came as no surprise that the town counc1l would devote the largest part of Its December 12 meeting discussing unemployment problems, since late in 1929 it became apparent to many that the unemployment situation was taking on important political and economic considerations? 87 The assistance the town offered the unemployed and the needy cost it RM 26,000 for the budget year 1928/29 (2.9\% of the total budget). ${ }^{88}$ The profected expenditure for the $1929 / 30$ budget year wis a modest RM 25,000; the trouble lay in the fact that ne town would have to supply $35 \%$ of the RM 25,000 during 1929/30, whereas it had only been responsible for $25 \%$ of the expenditure during the $1928 / 29$ budget pertod. 89 Considering the uproar which had surrounded the July budget debate, more unemployment and falling profits offered little prospect for a moderation of political demands. 
The Assoclated Union was cognizant of the growing unemployment, but did not go beyond urging the council to give the unemployed a chance at a job by sponsoring town projects. 90 Besides the unemployment puzzle, the union took a stand against the NSDAP-DNVP sponsored referendum vote which was scheduled to take place on December 22 . The SPD leaders had simply told its supporters to stay away from the polls. 91

The Landbund reduced the issues surrounding the referendum to the simple statement that the costs of the Young Plan were not bearable. 92 The ald they lent to the NSDAP in the days before the election was critical for success, since the Landbund commanded a solld block of voters and the police had banned the only NSDAP public meeting before the vote. 93 Replacing public discussion were advertisements placed in the Anzelger which urged voters to go to the polls and stop the Young Plan which would only mean "elghty-seven years of hunger, crisis, and misery for you, your children, and their ch1ldren." 94 Since the NSDAP had established a political foothold In Pfungstadt during 1928 and 1929 and had the support of the Landbund, the result of the vote was respectable. Of the 4,893 people who were ellgible to vote, 417 opted to use their right at the polls. The vast majority, 404 , voted for the repeai of the Young 
Plan while only nine hearty souls voted "no."95 The most significant aspect of the election was acceptance of the NSEAP as a legitimate political movement which, in the minds of at least $8 \%$ of the electorate, was not Just another radical party, but a vericle of change, a means of expressing the frustration and resentment that was stored in their hearts against the fallure of their expectations. The NSDAP was becoming a viable alternative.

The last month of 1929 provides a prophetic look at the challenging years about to face the inhabitants of Pfungstadt. The problems, the cast, and the prefudices were established--the agonizing death of a soclety had begun. 


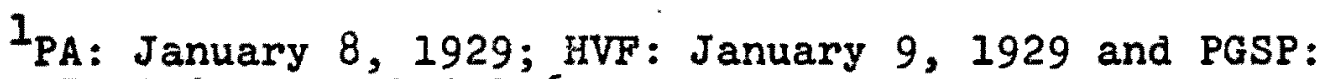
January 7, 1929, pp. 133-136.

${ }^{2}$ Interview with Julius Winkler.

${ }^{3} \mathrm{PA}:$ January 23, 1929.

${ }^{4}$ Interviews with Julius Hofmann, Marla Schulz, Wilhelm Kaffenberger and Luise Steinmetz. Georg Llebig (SPD) remarked, "The mlddle class did have to pay more taxes than the workers. The SPD made a mistake in saying that only the poor would remaln, while the NSDAP sald that they would support the continued existance of a strong middle class."

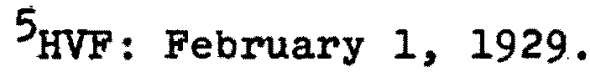

${ }^{6}$ Interview w1th Jacob Brauer.

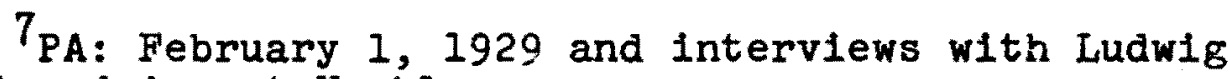
Gunkel and August Hechler.

$8_{\mathrm{PA}:}$ March 5 and $8,1929$.

${ }^{9} \mathrm{PA}:$ February 12, 1929.

${ }^{10}$ PA: February 24, 1929. The tobacco workers were an exception; they had suffered a severe reverse over the previous five years because of tobacco factory closures in Pfungstadt.

${ }^{11}$ Interview with Jacob Delp.

${ }^{12} \mathrm{PA}$ : February 23, 1929.

${ }^{13}$ Interviews with Johann Kölsch and Jullus Winkler.

${ }^{14} \mathrm{PA}$ : March 11, 1929.

${ }^{15} \mathrm{PA}$ : March 12, 1929; HVF: March 13, 1929 and PGSP: March 11, 1929, pp. 144-147. 
${ }^{16}$ Interviews with Adam Ruckelshausen, W1Ihelm Kaffenberger and Jullus Hofmann.

17 Interviews with August Hechler and Georg Iiebig.

18 PA: June 4, 1929; HVF: June 5, 1929 and PGSP: June 3, 1929, pp. 153-155.

${ }^{19}$ PA: July 5, 1929; HVF: July 5, 1929 and PGSP: July 4, 1929, p. 158.

20 HVF: July 13, 1929 and PGSP: July 11, 1929, pp. 159-160.

\section{${ }^{21}$ Ib1a.}

22 Interview with Adam Ruckelshausen.

${ }^{23}$ PA: February 10, 1929.

24 HVF : February 14, 1929.

25Interviews with Peter Crößmann, Georg Llebig and Georg Herth.

26 HVF: Apr11 11, 1929.

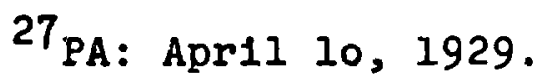

28 HVF: Apr11 12, 1929. The case against one of the KPB defendant was dropped.

29 $\mathrm{HVF}$ : Apr11 17, 1929.

${ }^{30}$ Notes from the private flle of Heinrich Huxhorn.

${ }^{31}$ PA: May 18, 1929 and interview w1th Georg Herth.

${ }^{32}$ Interviews with Jacob DeIp and Karl Emig.

33 $\mathrm{PA}$ : May 2, 1929 and HVF: May 2, 1929. 
34

Ib1d.

${ }^{35}$ Interview with Georg Herth and Peter CröBmann.

${ }^{36}$ PA: June 8, 1929.

37 PA: Juiy 22, 1929.

${ }^{38} \mathrm{PA}$ : July $16,1929$.

${ }^{39}$ Interv1ews with Johann Kölsch and Ludw1g Wenz.

40

Jahre, Herausgegeben vom $\frac{1 \mathrm{~m}}{\mathrm{Hes}} \frac{\text { Wandel }}{\mathrm{sischen}} \frac{\text { der }}{\text { Statistischen Landes- }}$ amt, (Wesbaden, 1960), p. 126.

${ }^{41} \mathrm{PA}$ : August 24, 1929 and HVF: July 31 and August 27, 1929.

${ }^{42}$ PA: July 10, 1929.

${ }^{43}$ Interviews with Helnrich Sand and Helnrich Schaffner.

${ }^{44}$ PA: July 12, 1929.

${ }^{45}$ Interviews with Jullus Hofmann, Johann Kölsch and Peter Crößmann.

${ }^{46} \mathrm{PA}$ : August 12, 1929 and an outline of the festivities in HVF: August 9, 1929.

${ }^{47}$ PA : August 13, 1929.

${ }^{48}$ Interview with Ludwig Wenz.

${ }^{49} \mathrm{PA}$ : September 5 and 10, 1929 and HVF : September 2, 1929.

${ }^{50}$ PA: August $31,1929$. 
$51_{\mathrm{HVF}}$ : September 3,..1929.

52 PA: September 14, 1929.

${ }^{53}$ Interviews with Jacob Hanbuch and Helnrich Sand.

${ }^{54} \mathrm{PA}$ : September 18, 1929.

${ }^{55}$ Interview with Ludwig Gunkel.

${ }^{56}$ PA: October 1, 1929.

$57_{\text {PA: October 1, } 1929 .}$

${ }^{58}$ Interview w1th Adam Ruckelshausen.

$59_{\text {HVF }}$ October 2, 1929.

${ }^{60} \mathrm{PA}$ : September 28, 1929 and HVF: October 2, 1929.

${ }^{6 I_{\text {Ib1d }}}$ and Interview with August Hechler.

62 HVF: October $5,1929$.

63 $\mathrm{PA}$ : October 8, 1929.

${ }^{64}$ Interview with Julius Winkler.

${ }^{65} \mathrm{PA}$ : October 8, 1929.

${ }^{66}$ Interview w1th Jullus Hofmann.

${ }^{67}$ PA: October 14, 1929.

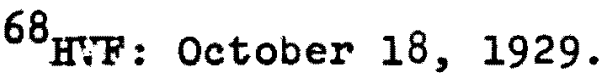

${ }^{69}$ Interviews with Jacob Delp, Georg Herth and Georg Llebig.

$70_{\mathrm{HVF}}$ : Octocer 28, 1929 and interview with Peter Crōßmann. 
$71_{\mathrm{HVF}}$ : Octover 25, 26 and 30, 1929.

72 PA: October 31 and November 11, 1929; HVF: November 8 and 12, 1929.

${ }^{73}$ PA: October $30,1929$.

74 HVF : October 31, 1929.

${ }^{75}$ Interview with Heinrlch Sand.

${ }^{76}$ Interviews with Luise Steinmetz and Adam Ruckelshausen.

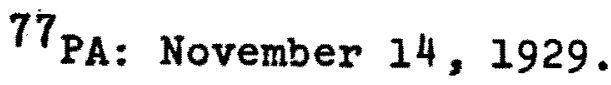

${ }^{78}$ PA: November 15, 1929 and Interview with Peter Crößmann.

${ }^{79}$ Interviews with Johann Kölsch, Heinrich Schaffner and Jacob Delp.

$80 \mathrm{PA}$ : November 18, 1929 and HVF: Noveminer 18, 1929.

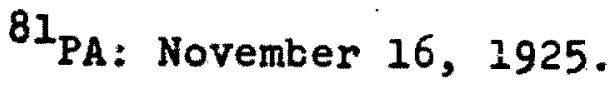

82 HVF: November 22, 1929.

${ }^{83}$ Interviews with Julius Winkler, Marla Schulz and Luise Steinmetz.

${ }^{84} \mathrm{PA}$ : November 23, 24 and 29, 1929.

$85_{\text {HVF : November }} 26$ and December 3, 1929; Interview w1th August Hechler.

${ }^{86}$ PA: December 3, 1929; HVF: December 4, 1929; PGSP: December 2, 1929, pp. 177-178.

87 PA: December 13, 17 and 18, 1929; PGSP: December 12, 1929, pp. 179-183. 
${ }^{88}$ Rechnung über E1nnahme und Ausgabe der Geme1nde Prungstadt für 1928 and 1929 , pp. 35 and 96 .

${ }^{89}$ It 1 .

90 PA: December 19, 1929 and HVF: December 18, 1929.

${ }^{91}$ PA November 23, 1929.

92 PA: December 21,1929.

93 PA: December 6, 1929.

94 PA: December 21, 1929.

95 PA: December 23, 1929. 


\section{CHAPTER V}

REALIGNING SOCIETY - JANUARY, 1930 TO JULY, 1930

Unemployment and insecurity, the most obvious outgrowths of an accelerating depression (approximately two hundred men were recelving town welfare payments on January 1, 1930, whlle only s1xty people were getting them on January 1, 1929), provided the bas1s for the pin-prick attacks which were eminating from the KPD and SteinmetzMartin. Thesse annoy1ng assaults upon the bastions of reason and stability in Pfungstadt became ingrained within a conflict which was polarlzing the cltizens and realigning the previous symbols of authority into new configurations. At the center of the changes which were taking place was the town council. The complexity of the situation and the importance of the stakes were mirrored In two discussions which filled the chamber in which the town council was meeting on January 6 . A debate of welfare rules and the implementation of work projects led Gemelnderat Martin to volce strong objections to what he characterlzed as the free spending habits of the SPD and the KPD. He specifically assaulted the purchase of stones by the town, stating that there was no use to be found for them. A SPD speaker acidly replied that they 
would be of use if the town would appropriate the funds necessary for the project. Whereas the bürgerlich and working ciass representatives on tine councll could find no common denominator concerning the alleviation of the problems of the unemployed, they could rally together to oppose a persistent thorn in their side. One of the results of the 1923 inflation had been the complete elimInation of the town's funding of the church debt. After the government mastered the inflation, the creditors of the church won a reappraisal of 1ts debt. The church, in turn, put pressure on the town council to renegotiate thelr support of the church. When an amiable solution could not be reached, the church sued the town hoping to reclaim a large portion of the funds: they felt were due. With one volce, the whole membership of the counc1l emphatically declared that they were resolved to oppose the church's sult. ${ }^{1}$ Financial difficulties were enough to form a block between the entire spectrum of parties in the counc1l and only provided one more reason for the inhabltants of Pfungstadt to 1gnore their Protestant Church. The SPD framed their work in the counc1l around one main 1ssue after 1929: "Work must be found for the unemployed." 2 This simple formula proved difficult to apply in practice. Over the months the SPD suggested that more men should be given jobs cutting wood in the forest, that 
more houses should be bullt with the unemployed supplying the labor, and that the unemployed could profitably be used constructing streets and sewers. But the KPD's success at the polls in 1929, coupled with their new-found desire to steer a completely independent course in the council, meant that the SPD could only muster ten votes in the counc1l (eight SPD members plus the mayor and the vice-mayor) to the ten votes of the KPD and bürgerlich. Since the middle class representatives in the councli were not interested in compromising with the SPD when the issue involved a possible increase of the tax burden, which they felt was already too great, compromise solutions of any sort were difflcult to achieve. A classic example of the situation as it had evolved in Pfungstadt by 1930 occurred when the SPD suggested that more emergency housing should be built. The so-called Flachbauten was under construction in the northwest section of Pfungstadt at the time, but their limited facilities did not promise much rellef for the housing problem which existed in 1930 (see page 22). When the SPD faction offered a proposal to the councll for more housing, Gemelnderat Martin countered by suggesting that the families in the Mühlberg settlement (small wooden housing belonging to the town which had orlginally been intended only as an emergency measure Immediately aster World War One) should yleld their homes 
to families which had a large number of children. Interestingly enough, Helnrich Huxhorn, who always suspected Mrrtin of some ulterior motives, rose to his feet to declare his support for Martin's measure. Realizing that this meant that the counc1 1 . would not approve the proposal, the SPD, for the moment, allowed the matter to ale. 3

The pendulum of SPD - KPD cooperativeness swung back toward a more productive arrangement when discussion In the council concerning the sale of town land to the SAJ (Sozlalist1sche Arbe1ter Jugend) began. Th1s 1ssue divided the councll along strlct worker-bürgerlich lines. The interests of the working class were so obviously involved that the KPD did not dare block the SPD measure. Over the strong objection of Steinmetz and Gräff (NSDAP) the SPD proposal to sell the SAJ city-owned land for thirty Pfennigs per square meter was passed. The depth of the opposition of those two was so intense that they had proposed that the land should not be sold for under one mark fifty per square meter. ${ }^{4}$ The SPD emerged from the tussle with a win: in the fray they had to concede the KPD more ground because they had to legitimitize KPD propaganda which stated that the KPD would not fall the workIng class on truly significant 1ssues. The KPD had to be accepted as a partner, even if only a funior partner, by 
the SPD if it wished to advance its own programs. The SPD was belng squeezed from both the right and the left-tu side with the KPD too often in the counc1l risked the bürgerlich charge that the "reds" were not respons1ve to the pleas of the middle class for a balanced economic response to the serious financlal crisis at hand. Too close a working relationship with the middle class only Invited the charge from the left that only the KPD could adequately represent the interests of the workers in the counc1l. A natural inclination within the membership ranks of the SPD to side more openly with the KPD tended to compound the problems which faced the leaders of the party. 5

Around the financial standing of the town revolved the most intensive debts of the first half of 1930. At the council meeting of May 22 the good news that work on the Flachbauten was proceeding smoothly had to be balanced against an ominous report of the fifty thousand marks the town council had borrowed from the state for the construction of housing in the Fall of 1930; only twelve thousand five hundred and fifty marks remalned to be dispersed. The news shocked the councd] nembers who had expected the funds to stimuiate Pfungstadt's lagging economy. The announcement sparked a bitter exchange of recriminatory remarks between SPD-KPD members of the council and the midale class members who took the opportunity to drive home their 
Idea that such irresponsible financlal operations would surely destroy the fiber of the middle class in Pfungstadt--the basis of a stab?e, prosperous community in their opinion. 6

The underlyling problem, everyone realized, was unemployment which sapped the dignity from a man just as quickly as it plunged the town into serious fiscal difficulty. Since the SPD proposals for street construction by the unemployed remalned impaled upon the problem of adequate financing, the councll could only listen once again to the SPD's proposing that men be given jobs by the town in some sort of construction work. A bürgerlich member of the council dryly remarked that at a time when the demand for welfare payments was increasing (the counc1l had budgeted twenty-five thousand marks for unemployment pay for 1929/30 while fifty-one thousand seven hundred and twenty-six marks was actually distributed ${ }^{7}$ ), which meant an increased tax load for a people already unable to pay them, such talk was irresponsible. The SPD felt itself a hunted animal in such clrcumstances. Unable elther to demand more radical solutions or to relax their championirg of the "workers rights." The KPD, free of such limitations, felt itself better attuned to the mood of the working class electorate, and moved to fill the gap which the SPD left. Huxhorn bellowed that the unemployed were belng cheated out of thelr weifare payments 
by a slow and unresponsive bureaucracy whlch took much too much time processing applications and officlal documents. H1s broad side struck a tender area within the ranks of the unemployed who more and more looked to the KPD to provide a solution to the ever more pressing forces which were grinding them down.

As early as January the ineffective nature of the Associated Union's response to the reports of layoffs and unemployment had been revealed when the leaders of the Union could only suggest that the unemployed avail themselves of the service of the work bureau which existed In Pfungstadt for special problems. Additionaliy they offered the council their opinion that the time had come to raise taxes and cut the rent for city-owned apartments, but nelther proposal had any chance of adoption. The measures were put forward in the hope that they would hold the membership of the Union together, more than for their actual application, which the Union realized would be asking for trouble. 8 The Union also sponsored a number of meetings for the unemployed, but they only provided the KPD with a platform for the propagation of their own notions of the causes of the unemployment. One of the Union's meetings was completely disrupted when a KPD spokesman charged that the Union had made a substantial (RM504) contribution to the 1929 town counc1l SPD election fund. 9 The truth that the Union had only contributed 
RM 25 did not stop the KPD from distributing their charge on handbills throughout the working class section of town. Tc underline and expand their own differences and influence within the working class, the KPD sponsored a Rote Hilfe meeting on February 1 at which time they promised the unemployed and the working class specific measures for thelr rellef. These included the help they would lend anyone who was attempting to wade through the forms one had to fill out, and a charitable bureau to distribute food. 10

The SPD adopted a statement which had been drawn up by 1ts leaders whlch declared that the party was satisfied with the results of the town councll election, although more spade work was essential between elections among the potential electorate. A degree of resentment crept into the volce of Gemelnderat Walke as he discussed the financial situation of the town when he criticised the national authorities for not providing more financial support. Wālke emphasized that the KPD attacks on the SPD were merely opportunistic outbursts devold of realistic political thought. The next order of business was a unanimous declaration of approval and support for the SAJ's plans for the construction of their own meeting place (HeIm). The chairman (Schulz) charged that older party members bore a speclal responsibllity to young 
people in general, but specifically to their own cadres. 11 The Sozialistische Arbelterfugend announced at the time of the celebration of their tenth anniversary that they planned to move forward with their plans for the construction of a meeting place. They solicited funds door to door and enlisted the technical know-how and advice of older SPD and Union members. Swept along by the new-found enthusiasm of the workers, the Union suggested it might be time to bulld a hall large enough for the masses of people who could not be accommodated at any of the existing restaurants in Pfungstadt. ${ }^{12}$ The chalrman of the Union added that the plans of a Volkshaus would only have a chance of becoming a reality if the entire working class would remain united and dedicated to the 1deas of the Associated Union.

Consistent with its new policy of holding more meetIngs between elections, the SPD sponsored a public gatherIng on April 12. A Relchstag member (Dr. Quessel) spoke to the assembled members and guests about the general political atmosphere in Germany, (Helnrich Brüning had been appointed Chancellor on February 28), laying particular emphasis on the hard work the SPD would have to undertake if they were ever to bulld soclalism into the reality they wished. He specdlated that Brüning's cabinet would not be able to survive for long, Imposing upon the SPD the 
burden of being prepared for any eventual1ty. Seubert (Darmstadt) defended the fiscal record of the SPD, noting that the proposed economic policies of Dr. Schacht would be a disaster for the workers. He ended his remarks by saying that as an opposition party the SPD hoped to do more for the interests of the people, although he claimed that the present capitalistic crisis would not be easy to overcome. ${ }^{13}$ Seubert's speech provides a brief glance behind the seemingly solld facade of the SPD. The stress and strain which the depression was causing within the ranks of the SPD was becoming a focal point of some disgruntled members who wanted the SPD held to a strict MarX1st approach to the problem.

The unity of the working class which had been splintering away for some time because of the SPD-KPD rivalry ceased to be a war of words and became a real war for survival when the KPD dropped a political bomb of the first magnitude into the laps of the working class. On April 30 they announced that they would hold their own separate May Day parade. They invited "the revolutionary workers of Pfungstadt to come in mass" to demonstrate their determination to meet the problems of Pfungstadt head on. ${ }^{14}$ The KPD sensed that the time had come to present themselves as a total alternative to the SPD by increasing their infrastructure. S1gns of a "revolt" by the KPD had been 
numerous during the previous year, when they had attacked the SPD repeatedly for falling to live up to their promise to supply the unemployed with jobs. But the break they proposed with the Assoclated Union was more than just another attack on the SPD; it caused a rent in the fabric of unity in the working class, dividing it in two, and destroyed the notion which was prevalent among the workers: that at least in the Union the working class could form a solid front. More significantly, the KPD had reached a polnt of departure. It split away from the traditional relationship with the Union and the SPD in such a way that wounds were opened which would be hard to heal even when the threat of Nazism hung over the town. The workers were beginning to devour themselves. The growth of the KPD provided almost the perfect counterpolnt to the growth of the NSDAP which was taking place among the middle class. The KPD and the NSDAP were reaping the first polsoned fruits of the depression. The situation was becoming a race to the death.

The threat whic the KPD posed to the Union falled to materlalize. On Mal 2 the SAJ marched at the front of a large parade with a big red flag, followed by the Freie Turngemeinde and then, by profession, the workers. The goal of the parade was the Sportplatz where the workers assembled to hear Debus (Darmstadt) explain that "to 
overcome the power of world capitalism the workers would have to unite and retain a belief in their 1deals."15 He lauded the Union which had succeeded in attracting the vast majority of the workers to the rally while the KPD could only gather fifty people to their counter-demonstration. 16 The steady drizzle which had begun early in the morning tapered off, allowing the picnic to proceed while the Volkschor serenaded the workers and their fam1lies. The lack of support for the KPD and the fact that no disturbances had taken place seemed to bode well for the Union and the SPD. The only significant event to take place after May 1 (besides informal political discussion) was a march of SPD wives to a county meeting in the nelghboring town of Darmstadt. At the convention they listened to a speaker explain the role of "Socialism and Women." 17

While the most stinging political battles in Pfungstadt were being fought verbally by the KPD and SPD, the Naz1 party was making painfully slow progress toward convincing the populace that they represented an effective political alternative. The group coordinated its efforts with other units of the party in often bloody exchanges with opposing forces throughout southern Hessen. The brutal activism of the NSDAP reached a new high point when In M1cheistadt a Naz1 speaker declared that "blood must flow" before effective changes could be introduced. ${ }^{18}$ His 
stinging remarks only succeeded in inflaming the tempers of the assembled populace to full-fledged fighting. Besides the NSDAP only the DVP could muster enough energy to stage an assembly of their own on May 28. Their effort was limited to the showing of two films, one entitled, "In Remembrance of Stresemann" and "Graf Zeppelin:"19

The stablilty of the town's government rested upon the long years of service of 1ts many members. By 1930 a vast majority of the council's membershlp had held their jobs a minimum of ten years. Mayor Schwinn and V1ce-Mayor Welgel had been assoclated with the administration of the town for over twenty-five years. During that time the record of cooperation between the parties charged with responsibllity for the town had been consistently good. The working class representatives had avolded ineffectual radical language for the most part, while the bürgerlich members of the councll had played a constructive role, shunting aslde talk of a "red menace" to a large degree. Signs of a dramatic depression within the business sector radically altered the situation; at first only, indirectly, In 1928 and 1929; then much more actively and directly in 1930. The KPD had been the main new vehicle of dissent in the first months of 1930. They were jolned by the NSDAP off and on, although the Impact of the NSDAP, through the first haif of 1930, was not too signiflcant. The 
slack or vacuum, that the NSDAP did not move quickly enough to f1ll, was by a new group on May 22 when the formation of the Arbeltsgemelnschaft bürgerlicher Gemeindevetreter--the Bürgerliche Vereinigung--was announced. The group was composed of all the middle class representatives in the town councll under the de facto leadership of Herr Stelnmetz. The chief concern of the group was the financlal integrity of the town. They declared that they woula no longer stand by while increasing expenditures in the town budget were leading the economy to ruin. They further demanded that taxes be lowered, complaining bitterIy, "what good are town work projects for the unemployed when the taxpayer cannot keep on paying his taxes!" They then proposed that the Krelsamt be empowered to review each town budget and disallow any expenditure they deemed extravagant. Finally, they forecast that "the collapse of the middle class would be a catastrophe; that a healthy middle class is the surest and best basis for the healthy existance of both the state and the town." 20 The establishment of a "middle class Assoclation"seemed to be a positive move in the direction of more balanced governmental involvement by the bürgerlich in the political processes. The historical precedents for such an undertakIng were plentiful (one only need review simllar assoclations which were formed in 1906 and 1922), but beneath the healthy exterior lurked a decaying body politic. 
Fostered by the "non-political" group Stelnmetz-Martin, the group could have only a limlted effect on the town of Pfungstadt, because the important decisions as to the fate of Pfungstadt's economy were decided at the state, national, and even the international levels. Within the new group also lay the seeds for other more radical development. All the parties of the council, including the NSDAP, were included in the new association. The group, in effect, gave its stamp of approval, if not an endorsement, to the reliability and acceptability of the NSDAP. Most of the middle class inhabitants of Pfungstadt viewed both developments as a logical alternative to the dangerous growth of KPD and SPD power. 21

The formation of the group did not ralse the eyebrows of the middle class. It was not viewed as a wild experiment. But the hidden dangers of the group were very real. For at almost the same time stelnmetz and Martin were parading their concern for the financial affalrs of Pfungstadt before the voters, they established secret contact with the NSDAP. Realizing that the SPD and the KPD still had to be reckoned w1th, they did not reveal their association with the party to anyone outside of a very small group--not even other members of the NSDAP. 22 A number of people who joined the NSDAP before 1933 followed this course of action which complicated the 
erforts of the democratic forces of Pfungstadt to effectIvely combat the' spread of Nazism.

A most serious realignment of the basic forces of the soclety in Pfungstadt had taken place. Replacing the semi-solid structure of the working class were two orbits of competing groups--the KPD and SPD--who were locked in a mortal combat of their own. Opposed to the entire universe of the working class were the parties of the middle class who were themselves split into their own particular political paths. The older national parties were willing to risk the loss of their own personal identities for the common goal of defeating the working class under the umbrella of the new Bürgerliche Vereinigung. But the Bürgerliche Verelnigung was itself split more fully than anyone realized into the orbits of pro-Nazi support (even if for the most part hidden) and more or less pro-democratic adherents. Political resentment and headstrong prefudices had created a situation which even a political wizard would have found impossible to untangle.

In Iine with the prejudice of most of the middle class residents of Pfungstadt, the Anzelger printed an article which severely criticized the tax structure. The writer complained that no matter which way one looked, one could only see taxes. Exclalming that the people of Pfungstadt pald clty, state, and national taxes of $1,790,800$ marks $(1,117,400$ marks to the Re1ch), he 
recounted that older people could tell of a time when expenses were low and there were no taxes. Th1s type of t:ought was echoed in another article in the Anzeiger which purported to detall the taxes Pfungstadt would be contributing in order for Germany to pay off the war reparations. The article claimed that the cltizens of Pfungstadt could expect to pay an average of 244,600 marks per year unt1l 1987 when the final payment would be made. Both articles lamented that the present state of the economy would not allow such sums to be exported from the town without a severe situation developing. 23 The thinking of the gentlemen may have been enshrouded in a fuzzy haze of half-truths and propaganda; the reaction of a large segment of the middle class was only too real. Most were unable to bear their misery without quenching their hatred (for it had become in many cases outright hatred) on Imaginary or over-played scapegoats. Sane analysis of the real face of good and evil was fast fading from the scene.

Those venerable old fortresses of qulet solltude and good cheer, the clubs and assoclations every German town had in plentiful supply, were also becoming the victims of heated passions and political intrigue. The depth of the distemper had not spread as completely to the clubs as 1t had to the political area, but the atmosphere was fast becoming filled with the clouds of insecurity and 
resentment. The Protestant Singing Club sponsored the play, "Without God," early in the year in order to show the unhapplness of a Bolshevik whose hatred of God had driven him into misery. Only God, the group loudly proclalmed, had preserued the man from a terrible end and granted him the contentment he needed to find peace with his surroundings. 24 The KPD scoffed at the ideas, but a few bürgerlich members of the community used the words to reenforce their own conception of Iife.

The Turnverein Pfungstadt (middle class) realized that a change was spreading over the town by acknowledging that the group as a whole was not responsive enough to the needs and desires of young people. Th1s accusation set off a lively debate, with another show of members claiming that this was only an 1maginary wrong, that the club had kept 1ts promises to 1ts younger members. The war inside the group quietly raged on for weeks, with the forces of moderate change slowly gaining the upper hand to the dismay of some older members. 25 The fight for a new definition of roles was hardly a phenomenon which was Iimited to the political sector of the town.

The Krleger und Militärverein retalned its sensible policy of political neutrality throughout those trying times by concentrating on discussions of death benefits and electing new officers. Although they supported a small arms shooting committee wh1ch was charged with 
provlding each member the opportunity to become better acqualnted with the finer arts of various weapons, they did not press any of the cther members of the communlty to take part in their activities 26

Some people succeeded in carrying out the redefinition of the role of people upon the economic sector successfully. They decided to reapportion the wealth by stealing meat from poorly protected butcher shops at night, and by stealing potatoes from farmers both before and after the farmers could harvest thelr crops. A growing number of disputes were also being settled with the f1sts of the dissatisfied electorate, much to the dismay of large sections of the community. 27

The developments of the first half of 1930 were significant. The KPD began to take a much more stringent Iine against the SPD and the Assoclated Union. The Bürgerliche Verelnigung had been formed to fight for the political power they felt was rightly theirs, even if that meant accepting the NSDAP as a legltimate political factor. The realigning of the traditional seats of power In Prungstadt had only begun; the function of the new forces was only to become clear after a longer period of tlme had elapsed. The people of every group were beginning to sense that something had to be done about the intolerable economic conditions which were fast overtaking the Ilvelihood of the most determined Individuals. Unrest 
had grown considerably in the short interval of $s 1 x$ months. 
CHAPTER V - FOOTNOTES

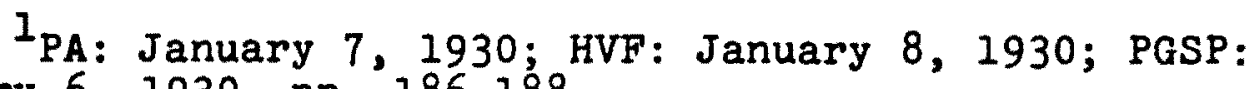
January 6, 1930, pp. 186-188.

2 Ib1d.

$3_{\mathrm{PA}}$ : March 18, 1930; HVF: March 19, 1930; PGSP: March 17, 1930, pp. 197-198.

${ }^{4}$ Ib1d.

${ }^{5}$ Interviews with Karl Emig, Georg Liebig and Peter CröBmann.

6 $\mathrm{PA}$ : May 23, 1930; HVF: May 26, 1930; PGSP: May 22, 1930, pp. 204-206.

${ }^{7}$ Rechnung über EInnahme und Aufgabe der Gemelnde Pfungstadt für 1929 and 1930 , pp. $\overline{35}$ and $9 \frac{1}{6 .}$

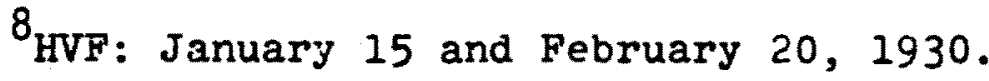

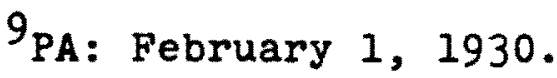

${ }^{10}$ Ib1d.

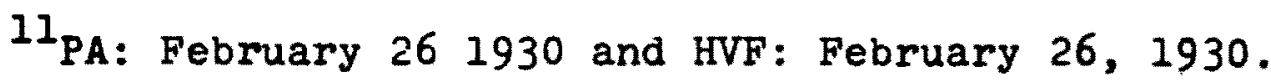

12 HVF : March 1, 1930.

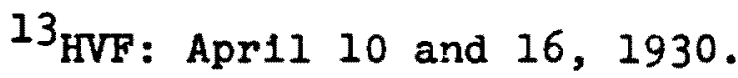

14 PA: Apr11 30, 1930.

15PA: April 26, 1930 and HVF: May 5, 1930.

${ }^{16}$ Interviews with Jacob Delp and Peter Crößmann.

$17_{\text {PA: June 5, } 1930 .}$ 
${ }^{18} \mathrm{PA}: \operatorname{March} 28,1930$.

${ }^{19}$ PA: May 28, 1930.

${ }^{20}$ PA: May 23, 1930.

21 Interviews with Jacob Brauer, Adam Ruckeslhausen, Luise Stelnmetz and Ludwig Gunkel.

22 Interviews with Heinrich Sand and Lulse Stelnmetz.

${ }^{23} \mathrm{PA}$ : Apri1 11 and May 3, 1930.

${ }^{24}$ PA: January 10, 1930.

${ }^{25}$ PA: February 3, 1930.

${ }^{26}$ PA: January 14, 1930.

27 PA: April 4, 1930 and Interviews with Ludwig Gunkel, Jacob Delp and Karl Emig. 


\section{CHAPTER VI}

\section{BASIC ADJUSTMENTS - JULY, 1930 TO JANUARY, 1931}

Like a large 1mmovable rock, the town counc1l dominated the poiftical scene of Pfungstadt. Instead of losing its near monopoly position concerning the political iffe in town, by July the vlews expressed by varlous members came to mirror ever more closely the general political trends of the populace. The debates whlch occurred in the counc1l set a tone for subsequent events which were to declde the struggle for power and influence. The town counc1l of July 10 devoted the major portion of its time to one topic: unemployment. By July, 1930, unemployment and the fiscal ramiflcations which it produced or induced, had come to play the major role in the lives of a majority of the citizens of Pfungstadt. In the case of the town counc1l, unemployment sparked fires of suspicion in the hearts of both the working class representatives and the bürgerlich: the former primarlly because of their concern for the use of the unemployed in some needful town sponsored undertaking, and the latter primarlly because of their anxiety concerning the means that would be used to finance that work. The council had approved the use of the unemployed for the cutting of wood in the town forest and more 
recentiy the employment of almost one hundred men on a project designed to clean up the banks of the Modau (stream) but the SPD never lost sight of their proposal to provide jobs through the construction of streets in Pfungstadt. They reasoned that a meaningful measure such as that would allow the unemployed to retain a greater amount of their self-dignity and self-confldence than the half-way measures the counc1l had been sponsoring. F1nancing for the project was to be provided through a serles of loans from the state. The expenditure of fortyelght thousand marks for the construction of streets was roundly condemned by the Bürgerliche Verelnigung. They claimed that: 1) the funds necessary for the undertaking would further damage the already highly taxed businessmen of Pfungstadt, pertaps fatally, and 2) the SPD figures for the costs were inflated, since a private contractor could handle the construction for one-half of the SPD's estimate. The Verelnigung an went directly to the inhabitants of Pfungstadt with zheir contentions in an article in the Anzeiger. ${ }^{1}$

The remarks of the Vereinigung elicited an emotionally tinged response from the Construction Workers wing of the Union Association. A spokesman acidly pointed out that the businessmen of Pfungstadt Implored the Inhab1tants to "Buy in Pfungstadt," but were not ready to see the working class "Earn in Pfungstadt." He bitterly complained 
that the Vereinlgung acted as if "the businessmen think that they are the only taxpayers in Pfungstadt." An equal distribution of the economic burden always played a prominent role in the election propaganda of the middle class parties, but in practice they wanted the workers to bear a disproportionate load. Warming to his role, the Union spokesman satirically asked, "Oh, how would it be if these men were in control of the government?" He closed with the ominous warning that "Whoever won't let the workers live, doesn't deserve to be (financlally) supported by the workers." ${ }^{2}$ The leadership of the SPD hastened to point out that they were ready to agree to the employment of a master craftsman as the primary vehicle for the job. However, they insisted that he be willing to parcel olit the work among the unemployed, not the members of his family or h1s apprentices. The Verelnigung re-entered the argument long enough to retort that the proposal was to give the contract for the work to the master brlcklayer with the least amount of work, regardless of his family connections. Shrewdily their agent charged that the men behind the unemployed (SPD/KPD leaders) were responsible for this disagreement; a disagreement, he claimed, the Verelnigung did not wish to use to punish the unemployed. He appealed to the town's inhabitants to make their minds up with facts, not demagogic rhetoric which only clouded the 1ssue. ${ }^{3}$ 
The SPD counc1l members had not anticipated such a spirited reaction when they had first submitted their proposal. They had expectad a toiken opposition from the bürgerlich for political purposes, but not the stubbornness they encountered. This same act had occurred a number of times during the 1920's. The SPD did not realize that they were dealing with a new set of factors. The center of direction within the bürgerlich factor had shifted; the old reasonableness had been displaced by the anxiety of the depression, and the leadership of Steinmetz and Martin, who did not view the problems of Pfungstadt with the same benign calm as their associates had. The displacement of the leadership roles within the bürgerlich was becoming more and more real. The winners of the feud were the practitioners of total opposition, Stelnmetz and Martin, who together with their colleagues were able to convince a large segment of the middle class that the SPD was really trying to folst off new taxes upon them. Undoubtedly they were also beginning to maneuver themselves Into a position which would allow them to consistently take a hard line in the upcoming budget debate. Another result of the SPD setback concerned the KPD. The entire process had been viewed by the KPD with obvious pleasure, since it supplied them with valuable ammunition for hit and run attacks on both the SPD and the bürgerlich. The leadership of the KPD formulated a series of strictly 
one-sided measures, arguing that the Vereinigung's catagorical refection of the SPD's modest proposals had once and for all torn the maske of seering reasonableness from the fact of the reactionary bürgerlich and the ineffectual SPD. Huxhorn calied on the workers to rally around the KPD, the one institution that offered people a real alternative to the machinations of the middle class and the bungling of the (pseudo-bürgerlich) SPD. ${ }^{4}$ The fate of the people of Pfungstadt was in part decided by the intransiance of the bürgerlich to meet halfway with the SPD, for, as events were soon to show, the real intention of several bürgerlich was not to find the proper master bricklayer for the job. A faction of the bürgerlich really intended to scuttle the whole council program of providing jobs for the unemployed--at nearly any price.

Between July 28 and September 2 no less than ten town councll meetings specifically dealing with the town's budget were held. The flrst measure up for debate at the meeting on July 28 was a proposal to ralse the level of taxation. The proposal had already been discussed in elght finance commlttee meetings where agreement on the rate of taxation had been reached after hours of dispute. 5 The rates were to be:

Profits -...- ra1sed from RM 1.50 to 1.90 per RM 100 Business Capital --- raised from RM .35 to .40 per RM 100 
Unimproved Land -- ralsed from $\mathrm{RM} .50$ to .56 per $\mathrm{RM} 100$ Bulldings and Lots --- ralsed from RM 1.25 to 1.27 per RM 100

Imposition of a special property tax of between RM 36.43 and 41.75 depending upon gross income.

Since the rolis of the taxpayers was shringing because of unemployment, the vast majority of the taxpaying populace would be paying significantly larger tax bills. The burden of the increases fell more and more on the shoulders of the middle class businessman. A very explosive resentment began to reach a peak, because the same middle class who were paying higher taxes felt that thelr representa( tives on the councll could never adjust the situation more to their liking as long as the SPD and the KPD controlled a majority of the council's seats. 6 A volatile predicament had developed. Some changes in the structure of Pfungstadt had occurred and even more basic adjustments could be expected.

A point by point analysis of the entire budget did not get under way in the counc1l unt1l July 31 . A host of onlookers provided a pertinent reminder to the counc1l that it held the fate of many people in its hands. The strategy of the KPD began to unfold almost at once. Huxhorn ard nis colleagues proposed the elimination of the small amount of wood which certain old members of the community recelved. They then turned their attention to the price of electricity, proposing a sliding rate scale, the 
affluent paying more, the poor paying less. Both measures went down to defeat through the comblned votes of the SFD and the bïrgerlich. Returning to the politics of reason for a moment, Huxhorn recommended the adoption of a law whlch would allow the unemployed to bathe in the town baths at no expense. The measure found immediate SPD support, and was carried. When Huxhorn had ended h1s attempts to alter the budget, it was the turn of W1lhelm Martin to take the floor. He offered a set of proposals which close1y paralleled those he had submitted the year before. (For a list of those proposals see p. 81.) In the intervening year the tide of middle class opinion had turned strongly in his favor. Thus a number of SPD counc1l members felt the need to support Martin's bid to reduce expenditures in the hope of keeping the life lines of communication open to the middle class. With this tacit recognition of the validity of Martin's stand as a base, his measures were assured of passage. But Martin was not content to rest with the acceptance of these minor changes. He again insisted that the charge for water had to be increased and the profits of the water works and the electricity work be applied to the general budget. These inftlatives ran into the same determined resistance they had met one year before, and were k1lled. The intricacy of the issues forced the council to remain in session until midnfght, when the mayor finally rapped his gavel for 
adjournment. 7

At the town counc1l meeting of August 4, another $e^{\prime}$ ement of divisiveness was added to the already stralned relations between council members. Strong personal attacks were launched by a number of members during a two and one-half hour budget debate. When the personal v1l1flcation died down enough every single revision of the budget proposed by both the KPD and the middle class was defeated. The meeting was again adjourned to a later date as the councll had found itself unable to resolve the complex difficulties it faced before midnight. ${ }^{8}$ The dazzling array of demagogic oratory which fllled the council chamber during the protracted discussion of virtually every budgetary item sapped the remalning good will out of the council members. Wh1le the KPD and bürgerlich Induiged themselves with their dangerous new toy, the SPD could not grasp the levers of power long enough to provide the leadership the council so badly needed. The intransient positions each side had decided to defend ser1ously undermined the confidence the average man in Pfungstadt had in the abllity of the counc1i to come to terms with the effects of the depression. Pathetically enough, the only 1tem on which the KPD and bürgerlich could agree was to strip the Corsititution Day celebration of 1ts offlctal financial support. The initial union of the extremes had produced a resnlution which tore a hole in the 
unity of the state. 9 A time of trial was upon the people of Prungstadt; and fifty percent of the elected representatives had falled the test.

When the council resumed deliberations on August 8 they were still mired down in a discussion concerning the amount of money the town's officlals should recelve. Martin had called for a slash in this expenditure, while? Huxhorn proposed that funds allocated for the construction of town housing should be diverted to the officials. Martin went so far as to declare that Welgel (vice-mayor) should not be allowed to vote, since the matter concerned his own salary. The meeting dragged on; the stalemate seemed to indicate that the council would conduct no more business for the night. Adam Büttel (Hardwerker und Gewerbeverein) finally mentioned that the discussion of the budget would proceed much faster if the various factions stuck to the facts instead of continually bringing their personal views into the debate. ${ }^{10}$ But his appeal fell on deaf ears.

The depth of the divergence of the views in the counc1l was underscored again at the counc1l meetings of August 12 and August 14. The KPD again and again submitted measures of an unreailstic nature to the counc1l. The heat of the debate was nowhere near the actual value of the substitutions which generally involved sums of less than BM 600. As soon as a KPD motion had been defeated, 
elghteen to two votes, the bürgerlich would resume the fearful comedy with opposing measures of their own that met the same fate. Finally, an onlooker who could contain himself no longer got to his feet and abrasively protested the character of the proceedings. The most the counc1l could do was to have one of 1 ts members remind the gentleman that: "As long as there are political parties, there will be differences of opinion." The spectator of course left the meeting dissatisfled and was soon followed by the members of the counc1l who agreed to postpone thelr deliberations once again because they had falled to resolve their differences concerning expenditures in the budget. 11

The counc1l chambers agaln became the scene of more misplaced selfrighteousness on August 18 and 21 . The attention of Pfungstadt's Inhabitants were glued to the sessions of the council to an extraordinary degree. Upon the stage of the council the KPD and the bürgerlich could play their destructive roles to the hilt. During the course of the debate over town emergency unemployment pay, the two sides competed with increasing vigor for their respective viewpoints. When the KPD proposed that the allotment for the unemployed should be ralsed from seventy-elght thousand marks to one hundred thousand marks, the burgerlich responded with the demand that it should be cut to forty thousand. After the predictable defeat of 
both motions, the KPD launched a new thrust in the1r campalgn for the "proletarlate" by demanding that the town Impose a "luxury" apartment tax. It took only a few moments for the counc1l to turn down this measure. But the Bürgerliche Vereln1gung could hardly walt to jump back Into the race to declde which side could manufacture the most chaos. They requested that the counc1l reconsider their earlier demand for an increased water rate, with yet another refusal by the SPD and KPD to pass the1r motion. The uninsplring maneuver continued through both sessions of the counc11. ${ }^{12}$ Ne1ther the two hundred men seeking work in the forest nor the average cltizen knew of an easy solution to the town's problems, but both real1zed that the intransigence of the factions in the counc1l had begun to make the difficulties seem unsolvable. More and more, the basic political survival of the polltical Iife of Pfungstadt was belng called into question.

At the town counc1l meeting on August 25 the entire matter of the 19:0/31 budget came to a head. The assembly opened with a heated debate of the merits of particular points in the context of the entire budget, with each side setting out its particuiar reasons for unhappiness with the final product. At 9:00 P.M. a motion was tendered for a vote on the whole budget. When the results were announced It was clear that the new constellation of political forces which had been gathering strength in Pfungstadt 
since early in 1929 had now galned a stunning victory over the remaining bastions of moderation. By pooling their strength the KPD and the Bürgerliche Vereinlgung secured enough votes to knot the votes of the SPD, the Mayor, and the V1.ce-Mayor at ten to ten, which meant that the town was without a budget for 1930/31. Each side took pains to point out that 1 ts action was based on the sincere bellef that they were serving the highest good, that their position alone lay within the realm of the acceptable. ${ }^{13}$ The terrible responsibility for the continued deterioration of the political life of Pfungstadt must be laid at the feet of the council, the highest political organ of the town. In the final analysis though, the KPD and the Bürgerl1che Vereln1gung must bear the greatest share of shame for the debacle because they had inflamed their followers to assume uncompromising stances in the face of the most complex and bitter difficulties. The SPDis reluctance to agree to some sort of political deal created for them greater problems than ever in a time when extremism seemed to be the most respected political attribute.

The calcilated effort of the Bürgerliche Verelnigung to defeat the 1930/31 town budget found a sympathetic response among the members of the middle class in Pfungstadt. The general feeling among that group was that the power of the "reds" had Increased too much and that the 
Bürgerliche Verelnlgung had rendered the town a valuable service by staving off financlal ruin. ${ }^{14}$ On August 28 the Anzelger published an article which had been submitted by the Vereinlgung. The writer took the position that the seventy points in the budget should have been submitted to the Krelsamt so that competent experts could have ironed out the inadequacles in the budget before it was presented to the council. Since this course of action had not been followed, the writer declared that a great majority of the people supported the Vereinigung when it had turned down the budget. He further claimed that the rejection of the budget was based on the high taxes which had been incorporated into the budget. ${ }^{15}$ The message of the Verelnigung was well worded. It played on a serles of real middle class sore points. The fact that experts had been excluded from a review of the budget fit in perfectly with claims saying that the SPD and the KPD were partles fond of exuding theorles, but falled the test of practical application. Together with the pent up anxiety many members of the middle class felt for their financlal and soclal standing in the town, the Verelnigung was struck a grlevous, if not fatal, blow to the old political order of the middle class.

The precipltate use of small dialogues and meetings by the KPD provided the basis for thelr attempt to claim a strangle hold on the working class. ${ }^{16}$ Their 
demonstration of hard-headed stubbornness in the counc1l added new volces to their movement. The KPD was in the envious position of making a political victory out of a practical loss, because they claimed that their measures and motions were all almed at improving the lot of the workers 1mmedlateiy. The SPD was accused once again of having sold out to bourgeolse interests. Both the Bürgerllche Vereinigung and the KPD had sicceeded in claiming that a negative action was a positive result. W1thin the framework of these new politics, prefudice and hatred were sure to make large galns. Whose galns they would be, became the burning question of the day.

Both the Assoclated Unfon and the SPD were very much concerned about the repudiation of the budget by the counc1l. The Unton scheduled a meeting on August 26 when they learned of the defeat of the budget even though they had a meet1ng billed for August 28. At the meeting a feeling of disgust hung in the a1r as several speakers followed one another with denunclations of the KPD and the Verelnigung. One pointed out that this was the first budget to have ever been rejected by a town counc1l in the history of Pfungstadt, whlle another noted w1th an Ironic wave of the hand that it had taken a combination of workers (KPD) and the businessmen to do the job. When the meeting was thrown open to general discussion, Huxhorn moved to counteract the blows of the UnIon's leaders. 
He used the time whlch was alloted to him to say once more that only the Communist Party of Germany would protect the workers while others ran to make accommodations with the bürgerlich. ${ }^{17}$ When Huxhorn and others had completed their criticlsms of the council's action, it was announced that a SPD member of the council would be present at the Union meeting on August 28 to explain some of the finer points of the budget and the reasons for 1ts rejection. A huge crowd filled the entire hall on August 28 to listen to Frledrlch Raab and Ernst Wälke give their reports of the counc1l's action. The two men, in a lengthly and detalled analys1s, charted the course the budget had followed to Its defeat on August 25, but saved their most stinging remarks for the KPD. They jolntly belittled the KPD for hurting the interests of the workers and causing disurity within the ranks of the working class. Huxhorn tried to turn the arguments of Raab and Wälke around during the flfteen minutes the leadership of the meeting alloted to him. He argued that the real protector of the working men and women was the KPD, wh1le the SPD was falling to unite behind the causes they held up so often in pubilc meetings and informal gatherings. ${ }^{18}$ A restless, half defeated, confused group of men and women wound the1r way out of the hall when the chalrman of the Unton finally adjourned the assembly.

All of the talk whlch occurred on the streets and in 
the homes of Pfungstadt could not pass the town's budget, and there was little reason to expect the town councll meeting to produce a new result when it assembled on September 18. The meeting was marked only by a vigorous exchange of verbal barbs between Martin and Raab as to who was responsible for the lack of a budget. They wrangled for some time over each other's shortsightedness before the council could move on to other business. The national government had ordered the imposition of a beer tax which was supposed to alleviate some of the problems which so many towns faced. But in Pfungstadt, both the KPD-SPD and the Bürgerliche Vereinigung were staunchly opposed to this new tax. They found the time to curtall their antmosities long enough to deal a telling blow to the hopes of the national government for such a tax in pfungstadt. 19 Such unity of opinion was very short lived. At the counc1l meeting on September 25 no progress could be made towards the acceptance of a new budget, although the SPD and the KPD could agree to approve a forty tounsand mark loan for the construction of streets. 20 The mayor was thus authorized to seek the necessary credit from a financlal 1nstitution. The councll meeting on October 2 should have proceeded as all the others had since August 25 , except that one small but signiflcant development intervened to alter the composition of the counc1l. Helnrich Huxhorn had begun to serve the sentence whlch had been meted 
out to him because of his involvement in the "Kattmann Incident." The time he was ordered to spend behind bars had been delayed for over 2 year, but, when his final appeal was turned down, reckoning was at hand. W1th Huxhorn missing, the SPD could muster ten votes to the nine votes that still remalned in the hands of the bürgerlich and the KPD. The bürgerlich and the SPD leaders had met privately in the meantime, but had been unable to resolve thelr differences. So when the counc1l gathered together In the town hall to confront the issue of the budget once again; a majority could be found to support the passage of the budget. A short serles of speeches preceded the actual vote which worked out in the favor of the budget. 21 The tables had been turned on the KPD and the Bürgerliche Vereinigung, since there was now no way for them to defeat the budget. The most they could expect for a resolution agalnst the budget would be a standoff defeat for the1r measure. But it was a sick political wind that blew in Pfungstadt when the only thing standing between real chaos and continued financial responsibility was the jall term of an important council member. The democrats of Pfungstadt could hardly expect such a development to reoccur each time a vital issue appeared before the counc1l. By approving the budget the SPD left themselves open to the charge from both the right and the left that they were opposing the will of a significant section of the 
electorate.

The Bürgerliche Verelnigung was quick to Jump on the band wagon of hatred which swelled up among the ranks of the middle class. At a public meeting on October 11 the charge that the new taxes which were included in the budget were too heavy to bear was brandished about before a large and receptive audience. One report after another by members of the council labeled the action of the SPD as detrimental to the wellbelng of Pfungstadt. More than one speaker declared that the average taxpayer was under tremendous pressure fust to pay the existing taxes, while an Increasingly desperate economic situation did not promise any rellef. One exclalmed that new taxes flew in the face of the just existance of the middle class, while more seconded the notion enunclated by others that only a decrease in expenditures would provide a path out of the economic shambles a large majorlty of Pfungstadt's citizens found themselves in. When the discussion died down, the people in attendance agreed to formulate a letter to the counc1l whlch would set out the1r objections to the new town budget. ${ }^{22}$ Several days later the leaders of the Verelnigung sent another letter to the editor of the Anze1ger to reenforce the1r stand against the budget and to complain that some people simply did not understand and appreciate the seriousness of the situation in Pfungstadt. They again directed an attack on the supposed 
over-payment of wages to town officials, concluding with the remark that the businessmen of Pfungstadt were under an extreme financial pressure. Such assaults struck a very receptive chord among the members of the business community and the farmers who, rightly or not, viewed the fiscal and political picture in Pfungstadt through the same glasses. The Bürgerllche Verelnigung could Justly clalm that it was only echolng the call for a stop to the "fiscal irresponsibility" that was lodged deeply in the hearts of a wide number of people.

Among the membersh1p of the SPD the flerce struggle concerning the budget had torn yet another splinter from the bark of unity which enclrcled the party. The SPD leadership reciprocated the Vereinigung's charges with a blast at the inappropriate nature of this group's claims when so many men were unemployed and forced to live off the tiny amount doled out by the welfare system. ${ }^{23}$ To many a SPD member the forty-one years of progress the SPD had made in Pfungstadt seemed suddenly to have lost 1ts sparkle. Their instinct told them to fight back, but their disunity did not allow them to concentrate on a single enemy. The lack of a clear target only played into the hands of the KPD, which relentlessly strove to blame the bürgerlich for all of the troubles of the working men In Pfungstadt. The foul seeds of despalr and undirected fear which had sprung up in the fertile soll of so many 
anxlous hearts during 1928, 1929, and the first half of 1930 bore frult in the last half of 1930.

At the town counc1l meeting on October 20 the whole 1ssue of the budget and the Verelnigung's objections was replayed before a large crowd of disgruntled onlookers. The signiflcance of the refurbished proposals of the Vereinlgung took on a much more important aspect when the mayor announced that the number of unemployed had risen to a point where the entire allotment for the flscal year 1930/31 had already been exceeded. The town was paylng out approximately two thousand six hundred marks per week to the unemployed. The mayor also reported that the attempt to find a source for a forty thousand mark loan to the town could not be found. These reports stimulated the counc1l to review its expenditures once again, with the Vereinigung achieving a number of new reductions in expenditures in the budget although they failed to push their proposal to ralse the price of water through the council. The new mood which prevasled in the council also produced an agreement to submit the whole question of the wages of town officlals to the Kreisamt for expert analysis. ${ }^{24}$ The position of the Vereinigung was partially vindicated. The consequences of the depression exerted a tremendous, all-encompassing influence on the c1tizens of Pfungstadt.

Playing a role equal to budget squabble in the 
political life of Pfungstadt was the Refchstag election campalgn of 1930. The election, scheduled for September 15, brought to the surface the pol1tical forces whtch had not engaged in the budget debate. Th1s means primarily the NSDAP. Their entire election campaign approach was keyed to motivating those people whose complaints were dominating the scene in Pfungstadt to come to the polls and vote for the Hitler movement. They concentrated their preelection propaganda on a few private gatherings and a heavy dose of newspaper advertisements during the three weeks before the election. 25 The ground had been amply prepared by the growth of the influence of Steinmetz and Martin, who had split the once dominate ranks of the national middle class political parties in Pfungstadt in a way the NSDAP could not in Pfungstadt.

Heinrich Huxhorn and his associates in the KPD were also determined to win thelr party a larger share of the votes. They approached the problem with two-pronged campaign tactics which combined periodic attacks on the SPD w1th a constructive thrust agalnst the problems of unemployment. It would be a drastic mistake to assume that the KPD produced only negative answers for the people of Pfungstadt. They took the lead in attacking the unemployment office for its inefficlency, and formed their own unemployment commission, under the chairmanship of Georg Herth, to flght for the rights of the unemployed, helping 
an Inordinately large number to gain their just benefits. 26 They attacked many of the real inequities which people had to face, although they often propagated their program with dogmatic diatribes. The militant attitude of the KPD whlch occasionally led to fights tended to drive the unsympathetic midale class even further away from the KPD, while the SPD tended to take on the appearance of an ineffective, some sald even cowardly, alternative. 27 In one instance a riot, in wh1ch a different KPD group was Involved, occurred in the nearby town of Bensheim and led to a wild chase through the countryside with one detachment of police hotiy pursuing a KPD group through Pfungstadt. Although the local party in Pfungstadt was not Involved, business men and farmers did not take the time to distinguish the differences between the two KPD groups? The major thrust of the KPD though was never almed at attracting middle class support, but to bring new members to the party from the ranks of the SPD. In this they were very successful. The KPD boasted openly that more and more Individuals ofned them in an effort to overcome the rampant crisis which could obvlously not be overcome through the traditional avenues. Since many workers did assume a more militant attitude toward their problems the SPD was sorely pressed to provide a more dynamic approach to their complaints.

Carlo Mierendorf responded to the invitatic of the 
SPD's leadership to blunt the KPD's aggressive propaganda. After dealing with the reasons behind Brüning's decision tn dissolve the Relchstag, he moved into the body of his speech declaring that the SPD would have to wrap their old traditions and bellefs in democracy and socialism in a new package of election methods if the party was to win a substantial number of votes in Hessen. Mierendorff's comments were well recelved by the large crowd in attendance, which thereafter listened to Ernst Wälke reaffirm the SPD's desire to see the orderly functioning of the government while they strove for reform. He noted that the town counc1l of Pfungstadt would do well if it heeded his remarks about orderly procedure. ${ }^{29}$ But more important personages such as Mlerendorff were not the only means the SPD had to stimulate the working class in Pfungstadt. The thirtleth anniversary of the Frele Turngemelnde Pfungstadt (the SPD sponsored gymnastics club) provided the base from whlch a host of workers could recelve SPD propaganda. A massive celebration which lasted three days In July was filled with exhibitions, speeches, and singIng and was attended mostly for the luster of the SPD and its institutions. 30 The subtle reenforcement the SPD acquired from such undertaking was credited with maintaining the aura of continuity which the KPD simply could not offer. The average working man still enfoyed his attachment to the tradicional that the SPD represented, 
although some felt that the dust of old age clogged the mechanlsms of the party.

The Assoclated Union, although technically politically neutral, provided the SPD w1th another strong arm. with which to ward off the frequent critlcism of the KPD. Peter Crobmann, the chalrman of the Union, took the lead among the officlals of the workers in promoting the continued celebration of Constitution Day in August, even though the appropriation which the town had previously made, had been blocked by the the KPD and the Bürgerliche Verelnigung. He urged the democratic bellevers in Pfungstadt to turn out in masses for the parade and speeches which were scheduled for August 11. H1s expectations were not mislaid as a large number of clubs, both SPD and middie class, continued to support the events of the day. Two bands provided a festive backdrop for the marchers who trooped through the streets to the sportplatz to hear a long speech honoring the Welmar Republic. The princlple speaker, Basthuisen, called for the upmost soclal justice in in the state as an alternative to dictatorship and warned the people assembled that, "radical solutions aren't golng to cure unemployment 11ls; only practlcal work w1ll help."31 Unfortunately, those Individuals who most needed to hear the words of warning stayed away from the gathering. Eagerness for an election battie permeated more than Just the ranks of the SPD and KPD; the middle sess parties 
responded with enthuslasm to the challenge which lay before them. Dingeley was the featured speaker for the DVP as they set their election campaign moving. He stressed the basic theme which the party was to enunciate throughout the weeks before the election: the middle class who stood on Hindenburg's and Stresemann's side for Germany's salvation should rally to the DVP. The leaders of the party stressed the ability of the DVP to rule--1ts years of experience and 1ts penchant for order. ${ }^{32}$ They dropped any reference to the French occupation of the left bank of the Rhine, since the French had evacuated the area. Just before the election the DVP held another meeting, almed primarily at the women of Pfungstadt although the youth was not forgotten. The membership of the DVP went out of Its way to stress to the women assembled that only they stood for order in time of chaos, with thelr time-tested answers not radical theorles. 33 Curlously enough, the leaders of the DVP felt much more at ease campalgning for national office than they had during the town council election. They felt that Stresemann's close assoclation with the leading figures of Germany lent them more prestige than the subsidiary roles they had so often played in the town council. A note of optimism crept into the speech of the DVP's local leader, Hofmann, whenever he discussed the upcoming election with his intimate friends. Just three days before the september 15 election the DVP 
ropeated the same basic message they had presented to the electerate throughout the campaign at another meeting. The stable, traditional outlook of the DVP was reenforced before the eyes of the voters as they stressed that "a slck state cannot be cured through radical means," and profected the image that a vote for the DVP was a vote "for H1ndenburg and the fatherland." 34 A renamed and reorgan1zed Deutsche Staatsparte1 (hereto the Deutsche Demokratische Parte1) briefly tried to stir up some enthuslasm for themselves at a gathering in the Hotel Straup. But the only message they could bring to the voters was that they "shouldn't vote for an interest group, (but) for a national party." 35 The long liberal tradition which had mantfested 1tself for almost one hundred years in Pfungstadt was dying an unhonored death in the side streets of voter Indifference. Virtually unnoticed the DSP addressed Itself to secondary issues in the minds of its earlier const1tuency.

The SPD again dominated the political campalgn in terms of sheer volumn of campaign material and public meetings. Meetings held on August 21 and 28 prepared the SPD for a final, all-out, push to last two weeks before the vate: On September $4 \mathrm{Dr}$. Kraus (the mayor of Mainz) spoke to a Jammed assemt $1 \mathrm{y}$. He old the crowd that only a vote for the SPD could produce any action agalnst Brüning's emergency decrees, particularly those which dealt with 
unemployment compensation. ${ }^{36}$ Before a second SPD voters: meeting was scheduled on September 12, placards, slogans, and a series of far-ranglr. many of the walls of Pfungstadt. At the September 12 meeting May Lux (N1eder Florstadt) exclalmed to another capacity crowd that the upcoming election would decide the fate of Germany. He lashed out at extremism (he was referring to the KPD) and pleaded with the workers to bear the responsibllity for the safety of Germany. 37 The main issue for the SPD throughout the election was the Interests of the working class and the possible effect that the KPD would have upon the long assoclation of the workers with the SPD. The middle class electorate of Pfungstadt was left without a morsel of recognition by the SPD which considered those votes as the virtual property of the bürgerlich parties. Besides an active participation in the political process in Pfungstadt the SPD sent a number of speakers to a number of meetings throughout southern Hessen. The membersh1p of the KPD generally traveled as a group to other assemblies, as other local groups needed the Influx of strength the group from Pfungstadt provided to present a respectable front to their own voters. An order by Leuschner, the Interior minister of Hessen, banning the movement of KPD and NSDAP members by truck, wagon, or bicycle just before the election, crimped the political activity of Pfungstadt's 
KPD. ${ }^{38}$ But the measure did not hinder the local NSDAP party because it did not engage, as a group, in extensive outside propaganda.

Mass confrontations between political opponents was a rarlty in Pfungstadt, although it was common for working class Individuals to involve themselves in political discussions over a glass of beer and end up in the street using their fists to decide the justice of the issues. 39 The few fights that broke out were part of the traditional aspect of campalgns rather than prearranged or serlous rents in the stable political order. The middle class hardly took note of those events because they infrequent1y v1s1ted restaurants where such things could take place. The later part of the campalgn saw an increase in the violence assoclated with the distribution of propaganda placards, but not to the point where 1t made an Impact on the electorate. Every day the newspaper (Anzelger) was f1lled with advertisements for every party. The final message to the people of Pfungstadt in the papers stressed the discomfort and apprehension of each party with the existing strains whlch had been generated by the depression. There were two winners in the September 14 election: the extreme parties, the KPD and the NSDAP. The KPD increased 1ts strength from 494 votes (12.21\%) in the 1929 town counc1l election to 923 votes (21.37\%), whlle the NSDAP made even a more dramatic expansion. They climbed 
from $206(5.09 \%)$ in 1929 to 882 votes (19.47\%) in the Refchstag election. A significant loser was the SPD which fell from 1710 votes $(42.05 \%)$ in the town counc1l election to $1639(36.17 \%)$ in 1930 . But the real losers, on the basis of the returns, were the established middle class parties. They suffered a sharp setback, dropping from 1366 votes $(33.76 \%$ ) in 1929 to only 1087 votes (23.99\%) after the Relchstag election. 40 Simply stated, the exiremes won a substantial victory; galning control of 1805 votes $(39.84 \%)$ in a town whose electorate was fast losing 1ts falth in the traditional answers to the overwhelming problems which surrounded the depression. The crisis of confldence which had lain just below the surface of the inhabitants of Pfungstadt had broken out with a force that threatened to slash the cohesiveness of Prungstadt's soclety to shreads. An extremely dangerous level of polarlzation gripped the people of Pfungstadt.

Whereas the NSDAP had made only a token effort to attract voters to their party before the Relchstag elect on, the leadership of the local group staged more than seven public meetings before the end of 1930. Barely one week after the results of the election were announced, on September 24 the NSDAP held a "discussion evening" (Sprechabend) In Weder's Cafe. Throughout October the pace was kept at a steady gallop, w1th meetings on October 8,15 , 
and 21.41 on November 5 the emphasis was shifted to the SA, but only for the one gathering, as more Sprechabenden wre held for the exclusive propagation of party propaganda on November 12 and December 6 . The December 6 meeting represented a peak of activity, as the NSDAP assembled at the home of W1Ihelm Kaffenberger to listen to a Naz1 member of the Darmstadt town counc1l, Zürtz, discuss town polltics. ${ }^{42}$ The stepped-up tempo of the NSDAP yellded rew tangible results. Membership in the party remalned at a minimum, ${ }^{43}$ as most potent1al conscripts turned their attention to the town counc1l debates. The lack of ready support was due in large measure to the continued pressure the working class threatened to the financial order of any businessman who was rash enough to declare publicly that he supported the NSDAP. Wh1le members remained few in number, the intangible breach the NSDAP had made in the subtle barrier between respectablilty and 1rresponsibility was of great importance. There were no shouts of doom or dispair emitted from the throats of the middle class because few bürgerlich took the time to bother facing the implications of the growth of the Naz1 party in Prungstadt. The few volces that were ra1sed against the encroachment by the NSDAP in the traditional balliwlck of respectablilty found virtually no echo. The Increased awareness of the middle class to the strength of the NSDAP did not indicate an appreclation of the 
party's program. In the minds of the harrled businessman, the Nazi party simply represented a more radical approach to. the Increasing opposition to the depression that lay in the increasing opposition to the depression that lay in the hearts of almost everyone. It provided an escape valve for 44.7\% of the middle class vote (a total of 1969 votes, 882 went to the NSDAP), while only $11.2 \%$ had elected to place their mark beside the Naz1 candidates in 1929. A serlous apprafsal of Nazi intentions may not have been undertaken by the middle class, but clearly a large plurality felt that the Naz1 party's opposition to the depression was creditable.

The Inroads of the Nazi party were undercut in practice by the leadership position the Bürgerliche Vere1nIgung had assumed in the town council concerning finances. Although the one Naz1 member of the counc1l was a partic1pant in the movement, he played a subservient role to that of Stelnmetz and Martin, Try as they might, the NSDAP could not produce the same effective propaganda as the Verelnigung did. At the same time, the Verelnigung dit not object to the Naz1 presence in their ranks. The Veiselnigung reentered the flnanclal fight which had not lost any of 1ts importance because of the election, this time In the fleld of unemployment compensation. The leaders demanded that the lists of the unemployed should be checked to Insure that only those with legltimate problems be 
allowed to remain. The demand was backed with the hint that such action would result in large savings for the town, and could not resist reminding everyone that if the councll had heeded their advice from the beginning of the crisis that the town's financlal headaches would have been held to a minimum. 44 This was a new untested area of attack for the Vereinigung which denoted a new militancy and danger for the town, for they had been reluctant to challenge the power of the workers earlier. The confrontation promised to be interesting and bloody. The decisive thrust of Stelnmetz and Martin agalnst the citadel of working class hope illustrates the untenable position the older middle class parties found. Faced w1th the selfrighteous challenge of Stelnmetz and Martin, the leadership of the other niddle class parties wilted. The destruction of the credibility of their positions led many people to search for a party which would not "bow to the pressure of the reds." 45 In the case of town politics, this turned more and more toward Stelnmetz and Martin. But in national politios the only political party. to establish its credentials as an unabashed opponent to the existing situation was the NSDAP. Steinmetz and Martin had only a limited local appeal, not a national organization with which to work. The fallure of the national middle class parties to take a constructive lead, led directly to the defection of large numbers of sensible conservatives 
to dynamic proponents of change. Unfortunately, the highpowered activism of the advocates of change masked their inner degeneration. In tha growing crisis people rushed headlong towards salvation, forgetting to look and see if the road they were following might end in dictatorship. The DVP atiempted to rest a degree of independence from the middle class steam roller which Stelnmetz and Martin had constructed by calling for the wholesale prohibition of all political marches, the repeal of the law making August 11 (Constitution Day) a legal holiday, and a speclal tax rebate for individuals and companys which found work for the unemployed. 46 The words of constructive reform were drowned out in an atmosphere which was steadiiy becoming replete with the raw emotion of hatred. Pfungstadt's Nazis and Steinmetz-Martin understood this feeling only too well. Instead of concentrating their rhetoric on solutions, they dealt almost exclusively on problems. The case of the salaries town offlclals took home provides just another example. They boomed a message around town that an investigation of officlals' renumeration was in order, darkly hinting that some scandal was in the works. ${ }^{47}$ Just as they had with the payment the unemployed recelve, they charged fraud before seeking to establish the facts. The effect treness of the approach was awe-inspiring for they succeeded in staking out a wide territory of influence 
among all sectors of the middle class. The farmer and the businessman, who had been separated by tradition into occupationally opposed groups, found that their resentments allowed them to rally around a single new flag--the flag of Stelnmetz-Martin on the local level, the swastika flag on the national level. The feeling of unity of purpose, and power, these new associations gave to many is a basic factor by which the spread of Nazism came so quickly to Pfungstadt .

While a lively struggle went on among the middle class to find new heroes, the SPD and the KPD continued to jostle one another for the loyalty of the workers. The SPD quickly recovered from the stunned sllence with which they met their election defeat. But recovering from the shock of defeat did not mean that they had found a more productive way of grasping the initlative from the KPD. The leaders of the SPD decided to stress the recruitment of new members during a two week perlod early in November. Prospects were to be attracted to the party by handbills which were spread over most of the town; then high rankIng SPD Individuals attempted to talk with each interested party separately. A taste of the propaganda the party would use during the drive was released at an october 25 meeting, when one member implored the working class "not to be swayed by demagogues." 48 Coupled with the 1deological thrust of the SPD was the practical work of the 
Assoclated Union which had become more openly attached to the SPD after the increased activity of the KPD began, and the establishment of KPD unions. In order to combat the success of the KPD among the unemployed, the Union held a public meeting during November to discuss what practical steps could be taken for the alleviation of depression hardships. The Inftial measure under discussion was the formation of an unemployment commission, modeled in part after that of the KPD's. The assembled unemployed cast ballots for the leadership of the commission. To the satisfaction of the Union, and the SFD, two hundred and fifty votes were cast for a slate of Union members, while only flve votes went to a KPD delegation. ${ }^{49}$ While Union activity was concentrated on real alternatives to unemployment and the SPD was involved with winning new members, the youth group of the SPD, the SAJ, exposed a militant interpretation of the situation to public view-the celebration of the November 9, 1918 revolution. They added an interesting twist to the commonly held bellefs of the SPD concerning the intentions of the change from the Wilhelmenian form of autocratic government to democracy when one representative of the SAJ asked, "What good are all of our equal rights when they haven't brought us better conditions?" From this assumption the crowd went on to attack the capitalistic system of economics. 50 
They attributed the depression to the fallure of capitalj.sts to think of anything outside of profits. Th1s they stated should inspire the working class to flght even harder for a soclallst state. In December the SAJ moved to another field of battle. At a public meeting on December 19 the film "Po1son Gas" was shown to the assembled. youngsters in an effort to spark an ant1-war att1tude among the population. The next war, the speaker exclalmed, would be a total war involving the use of poison gas on a massive scale. The SAJ approved a resolution stating that their primary goal would be to awaken an awareness of the tragedy of war among the general populace. 51 But the combined effort of the SPD, the SAJ, and the Associated Union could not take the wind out of the KPD's salls. The street corner oration was the most effective means at the disposal of the KPD membership in their quest for monopolistic control of the workers. Since the major portion of the KPD leaders were themselves unemployed, they found both the time and the reason for deeply involving themselves in the battle for supporters. Supplementing the personal street appeals were infrequent mass public meetings. One such gathering took place on November 12 when the KPD leaders scheduled a meeting at which Kiel (Offenbach) launched a scathing assault on "the poor budget of the SPD." Almost one hundred interested spectators and a number of oppositional leaders attended 
the assembly to cheer or object to the KPD's pronouncements. 52 The aim of the KPD was to galvanize those workers wavering toward the party to move the whole way into the communist camp by stressing their gains in the Reichstag election while pinning the blame for lack of speedy remedies concerning the unemployed on the SPD. 53 At the street corner the KPD could concentrate on one person at a time, while at the public meeting they allowed, out of tradition, the SPD leaders to speak if they so desired. Peter cröBmann, the chairman of the Associated Union and an ardent SPD member, flavored the discussion with his own interpretation of the causes of the workers' problems. He told the assembled workers that the unemployed would not profit by the utopian promises of the KPD, rather by the hard constructive work of the SPD. Once again a primary problem for the SPD, and for that matter, the KPD, surfaced in the debate. The two opponents found a large number of polnts of difference which detracted from their abllity to analyze and counteract the subtle, submerged growth of the NSDAP. The preoccupation with the complex infighting between the KPD and the SPD coupled with the fact that neither party saw their first objective in adopting, the values of the middle class parties, led to a devaluation of their awareness of the Nazi danger. The middle class, on the other hand, tehaved as if they lived In a separate community, because they consclentiously 
fostered their own prejudices which necessarily excluded from middle class vocabularies the words that could bridge the gap separating the classes. The problems of the age demanded that each side reach a compromise, unfortunately neither could, or would.

The festering gap which almost eliminated communication and cooperation between the middle class parties and the working class parties reappeared in the town councll meeting of November 20. The meeting opened with the usual assortment of routine business, but soon jumped into a sea of raging storms when Heinrich Huxhorn got to h1s feet to announce that he was proposing that the counc1l dissolve 1tself. He based his unprecedented demand on the deep divisions that had been created during the prolonged budget debate and the results of the Relchstag election which he claimed clearly indicated that a large segment of the electorate was no longer represented by their personal preferences in the council. H1s words produced utter confusion in the councli's chambers, as his measure. caught all of the council's representatives completely by surprise. Mayor Schwinn came to the council's rescue by stating that the motion would have to be scheduled at a later date. 54 But the reprleve the mayor had given to the counc1l exploded quickly when the counctl turned 1ts attention to the employment of the unemployed. A vicious debate between Huxhorn and Martin ensued over the amount 
of funds the town could realistically expend for the unemployed. The arguments which were employed drove the debate to the limits of creclbility and enced in a vote the result of which no one was sure of. After only a four day delay the council was reconvened long enough to hear the mayor state that the council did not have the authority to dissolve itself. The bürgerlich nevertheless "voted" to discuss the KPD's motion, whereupon the SPD members protested the state of affalrs and walked out of the meeting. 55 The politics of irresponsibility had reached a new height in Pfungstadt by late 1930.

The next act of the suicidal play the council was to perform took place on November 27. By agreelng to argue the value of the KPD's motion to dissolve the counc1l at their new meeting, the councll found time to briefly unite against a national emergency decree instituting beer and Bürger taxes. 56 In one volce the council voted to reject Brüning's new fiscal measures. Just before the counc1l was scheduled to resume 1ts deliberations (on December 1 ), the Kreisamt released its long awalted report concerning the financlal standing of pfungstadt. The contents of the report were bitter-sweet medicine for each of the contending parties. The authors of the report informed the councll that there was a pressing need for the town to reorganlze its finances, both income and expenditures. The Bürgerliche Vereinlgung won a vindication of sorts, for the 
report called for a cut in offlclal's wages, specifically the vice-mayor. But the report also recommended that the town counc1l ralse the town's taxes to offset the increasIng welfare burden, something the Union had Insisted upon for months. 57 The mayor scheduled a discussion of the report for a later date. Looming over the ensuing period of time between council meetings was the knowledge of Huxhorn's proposal for the dissolution of the counc1l. Immediately before the December 1 meeting the SPD announced that they would boycott the session because of their dismay with the KPD measure. Mayor Schwinn could count only elight representatives (two KPD and $s 1 x$ bürgerlich) when he opened the meeting. With the possibility of effective discussion, let alone decision making, cut off, the mayor simply called for adjournment. At the close of the session a spokesman for the Bürgerliche Verelnigung announced that his colleagues would boycott the coming council gatherIng. 58 Thus only two representatives, both KPD, were to be found in thelr seats when the December 3 meeting "began." Devold of his usual opponents, Huxhorn delivered an impromptun lecture on town politics. 59 The final political action which took place in the councll occurred on December 22, when the allotment for the Winter Rellef (Winterhilfe) was set. Quite naturally the Bürgerliche Vereinigung called for fiscal responsibility and a cut in the appropriation, while the SPD/KPD attempted to increase 
1t. A not too friendly exchange of views resulted in final agreement on a measure much closer to the SPD's views than the middle class liked, They were:

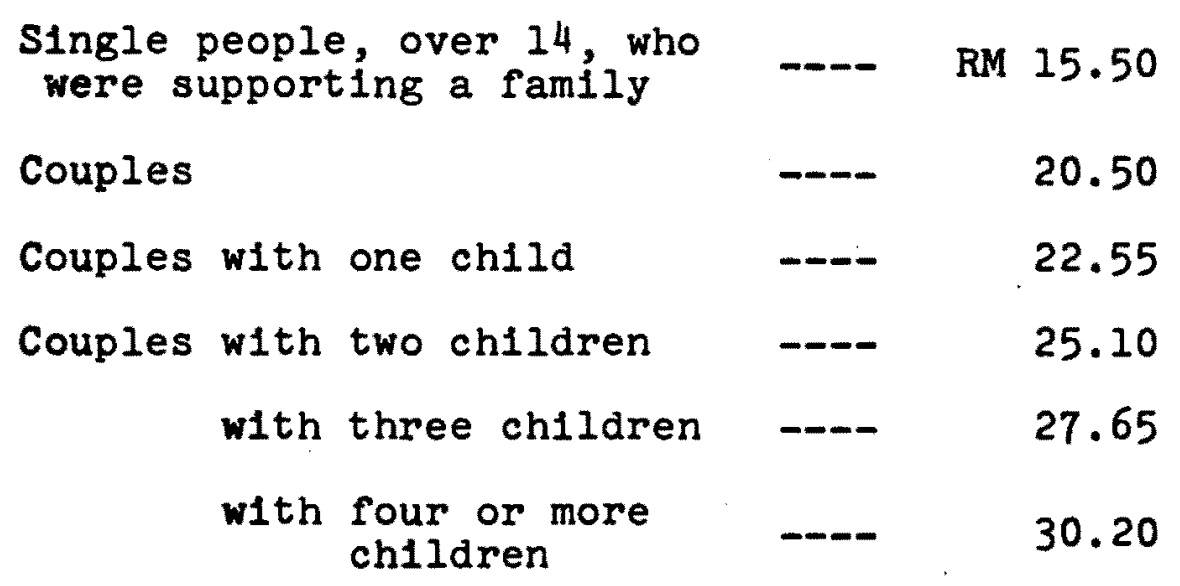

Payment was to commence on December 23 and occur monthly unt1l April: Interestingly enough, the NSDAP member of the council, Gräfr, who was also ortsgruppenleiter, supported the SPD proposal when it came up for final approval. In addition to the approval of the Winterhilfe, the council agreed to employ a large group of the unemployed in forest renovation work for wages below what the Associated Union had suggested. 60 Complexities were piled upon complexities as 1930 approached an end.

A seathing uneasiness had fllled the ranks of the STD after the Relchstag election and the vicious town counc1l meetings. To balance the adverse propaganda which the KPD and the Bürgerliche Vereinigung had spread against them, the SPD determined to busy its membership in a program of positive action. On December 7 the Relchsbanner called for the working class to come to a meeting at 
10:00 A.M. In order to announce the formation of a "Workers' Protective Organization Against Fascism and Dictatorsilp." Aitempting to regain the momentum which they had lost to the KPD, the leadership of the SPD announced that they had lost their patience for repellent demagogic abuse. "Action," one speaker said, "action is what we w111 demand from the organization." 61 The morning meeting was just the first half of a doubleheader plunge into the troubled waters of Pfungstadt's politics. In the evening of the same day Dr. Gumbel (Glessen) addressed himself to the problem of "the struggle between capital and labor" to a large pro-SPD crowd. He made a direct appeal for the people to remain true to the party--an appeal that was repeated by the party's local chairman, Schulz, in a short speech. 62 The double blow struck a respondent chord as over two hundred men joined the ranks of the new group which encouraged the SPD to pursue their revised policy 11ne. The success of the meetings and the newly established protective soclety easily left the SPD the largest group both in numbers and influence in Pfungstadt. The renewed vigor which the SPD demonstrated sharply contrasted to the frustrated almlessness the party leadership had demonstrated less than two weeks earlier. At that time the membership had wrestled with the unseemly dilemma Brünlng's emergency decree to introduce beer and Bürger 
tax had put them in. The leadership of the party explained that they would vote against these "burdens" although they realized that the tok h had tc have more income to support the growing list of unemployed. The SPD's stand for Increased taxes before the Relchstag election had undoubtedly cost them votes. They were determined not to make the same mistake again. Employlng, rather, more their instincts than their intellects, the leadership of the SPD determined that they were at a crossroads. One would lead them to attempt to win more influence among the middle class electorate, the other would signify a move to the left. The road to cooperation and gains among the bürger11ch was strewn with the rocks of past conflict and pltted with the holes of social inequality which the middle class held up to the SPD with a regularity and intensity which effectively destroyed any possible unity. The SPD, many of whom were veterans of the years of considerable struggle for the basic rights. They simply could not forget the pollce spies before the First World War, the sacr1fices for their country during a four-year school of destruction, and the soctal snubs and town counc1l squabbles of the twenties. Neither side had reached the point at which they could put out their hands to each other without risking disasterous repercussions from the members of their own classes. An attempt to recapture some of the supporters who had drifted into he KPD was soclally, 
1deologically, and organizationally more practical. The difficulty lay in moving to the left far enough without falling 1nto a KPD trap mentally. To retain a balanced responsibility, their trade mark for forty years, was to be an increasingly difficult task for the SPD in the days to come. One of the reasons the SPD could not resolve its difficulties was Helnrich Huxhorn. Under his intelligent leadersh1p the KPD outbid the SPD with proposals of a more radical nature. The leadership of the SPD was not prepared to compete with the irresponsible actions of the KPD for 1ncreased support. Huxhorn demonstrated h1s ample talents for hardh1tting analysis at an unemployment meeting on December 8. Those that attended came prepared to complain about the economic situation in Pfungstadt. Huxhorn's condemnation collected the thoughts of the crowd In an explicit condemnation of the leadership of the Assoclated Union and the "masters" who were wlthout feelIngs for the poor and downtrodden. 63 H1s appeal was electrifying. He and his colleagues felt the pulse of the unemployed and determined a course of action that outstripped the SPD in effectiveness and drive. The unemployed cried for change as vehemently as their middle class counterparts.

Meeting on December 14 the Bürgerl1che Verelnigung presented a number of reports by counc1l members concerning 
their actions of the past weeks. An extremely large number of people had turned out to hear Martin explaining the Implications of the Vereinigung's efforts to save funds and force the counc1l to acknowledge the difficultles of the businessmen of Pfungstadt. 64 Martin was treadIng through a maze which the Handwerker $u_{\text {. Gewerbeverein }}$ had discussed two weeks earlier, with the same warnings of disaster for Pfungstadt's business community. Even before then a group of craftsmen had pointed out that "work is the best sort of self-help." They desired a reduction In taxes, whlle they reaffirmed their bellef in the quality of thelr work, which they sald could not be compared with the mass-produced articles for sale in the department: stores in Darmstadt. 65 Thus the way for Martin and his colleagues in the Bürgerliche Verelnigung was prepared. Striking at a particularly vunerable chink in the defenses of the working class, one speaker declared that "Auf das Rathaus gehört kelne Pollt1k." Thls slmple statement summerized succlnctly the feelings of many businessmen andordinary middle class cltizens who felt that their economic difficulties stemed from the party's political emphasis which the SPD and the KPD placed before the general good of the town. ${ }^{66}$ Non-political "polltics" was a popular concept within the ranks of the middle class. But the mood of the people assembled by the Vereinigung on December 14 was ready to carry the concept even further. 
When a spirited discussion of possible alternative responses had ended, the assembled people decided to form a Kommunale Wähler Vereinigung (Community Voters' Assoclation). All interested voters were invited to join the Assoclation which was intended to further the interests of the middle class without assuming distinctive party outlines. 67 In one swoop the political picture in Pfungstadt had been changed again. While political blocks of the mlddle class parties had been formed in the past to oppose the SPD (and the KPD), the formation of an independent group of voters in a "local party" was a revolutionary development. With Martin and Stelnmetz at the head of a coalescing group of dissatisfled middle class voters the Influence of the established middle class national parties was undercut much more effectively than any Nazi onslaught possibly could have. At the same time support for the NSDAP was moderated, since the middle class citizens felt much more at ease with old friends and established leaders than the semi-questionable leaders of the NSDAP (Gräff was often accused of drinking to excess). The effects of the depression were more than fust economic, they spurred new forces and new prejudices to come to the forefront of a flght for survival which had created an unstable, freeflowing political atmosphere. An atmosphere aught with more danger than any democrat or authoritarles could real1ze. 
The year 1930 , was the real turning point in the history of Pfungstadt. New influences made their politlcal debut in an overwhelming manner. The KPD had jumped Into a contest for power w1th the SPD w1th both feet and had forged a large power pocket. The SPD was put on the defensive, the leadership moved with positive assurance to counteract the KPD's Inroads, but with limited success. The middle classes were more and more polarlzed against the workers whom they blamed in a large part for their problems. The bürgerlich screamed the loudest about unemployment and a falling economy, the hlgh taxes and the flscal difficulties of the town, while the working class drew their meager unemployment benef1ts. The working class carried the awful burden of the depression on their shoulders, while the middle class businessmen only feared the hole in his pocketbook but never had to suffer the Indignity of sitting at the side of the streets, aware that there was no work to be found. The forces for change were gathering their strength, walting for an opportunity to multiply the disaster in Pfungstadt far beyong the ex1sting level. Basic adjustments had been made in Pfungstadt's soclety: adjustments which promised to speed the disintegration of a soclety afflicted with most of the 11:. of the age. 


\section{CHAPTER VI - FOOTNOTES}

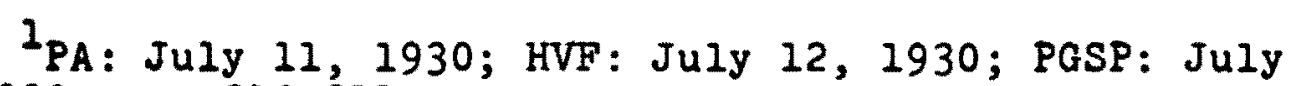
10, 1930, pp. 210-211.

2PA: July 14, 1930 and HVF: July 14, 1930.

3PA : July 16, 1930.

Crößmann.

${ }^{4}$ Interviews with Jacob Delp, Georg Herth and Peter

5PA: July 29, 1930; HVF: July 30, 1930; PGSP: July 28, 1930, pp. 212-213.

6Interviews with Julius Winkler, Jacob Brauer, W11helm Kaffenberger and Jacob Hanbuch.

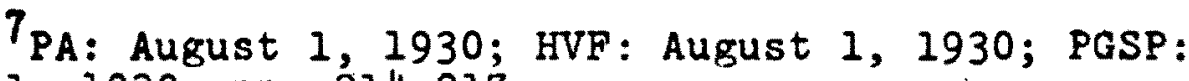
July 31,1930 , pp. 214-217.

${ }^{8}$ PA: August 5, 1930 and PGSP: August 4, 1930, pp. 218-219.

9 Ib1d.

10 PA: August 9, 1930 and PGSP: August 8, 1930, p. 220.

11 PA: August 13 and 15, 1930; HVF: August 14 and 16, 1930; PGSP: August 12 and 14, 1930, pp. 221-225 and 226-229.

12 PA: August 19 and 22, 1930; HVF: August 20 and 23, 1930; PGSP: August 18 and 21, 1930, pp. 230-232 and 233-235.

${ }^{13}$ PA: August 26, 1930; HVF: August 27, 1930; PGSP: August 25,1930, p. 236 .

${ }^{14}$ Intervis with Helnrich Sand and Jacob Brauer.

15 PA: Aug-st 28, 1930.

${ }^{16}$ Interviews with Georg Herth and Jacob Brauer. 
${ }^{17}$ PA: August 27, 1930 and HVF: August 30, 1930.

${ }^{18}$ Notes from the private file of Helnrich Huxhorn and Intervlews with Johann Kolsch and Jacob Delp.

${ }^{19} \mathrm{PA}$ : September 19, 1930; HVF: September 19,1930; PGSP: September 18, 1930, pp. 242-243.

20 PA: September 26, 1930 and PGSP: September 25, 1930, pp. 244-246.

2l $\mathrm{PA}$ : October 3, 1930; HVF: October 4, 1930; PGSP: October 2, 1930, pp. 247-250; Interview w1th August Hechler.

${ }^{22}$ PA: Ocrober 9 and 20, 1930.

23 PA: October 20, 1930.

24 PA: October 21, 1930; HVF: October 22, 1930; PGSP: October 20, 1930, pp. 251-253.

${ }^{25} \mathrm{PA}$ : September 12, 1930.

${ }^{26}$ Interview with Georg Herth.

27 Interviews w1th Karl Em1g, Marla Schulz and Helnrich Schaffner.

${ }^{28} \mathrm{PA}$ : July 7, 1930 and HVF: July 7, 1930.

${ }^{29} \mathrm{PA}$ : September 1 and 3, 1930 and HVF: September 6, 1930 .

${ }^{30}$ PA: July 4, 1930.

31 PA: August 12, 1930 and HVF: August 13, 1930.

${ }^{32}$ PA: August 30,1930

33 PA: September 6 and 12, 1930. 
34 Ib1d.

${ }^{35}$ PA: September 8, 1930.

${ }^{36}$ HVF: September 26, 1930.

37 PA: September 11, 1930; HVF: September 11, 1930; interview with Georg Lieb1g.

${ }^{38} \mathrm{PA}:$ August 16 and $18,1930$.

${ }^{39}$ Interviews with Heinrich Schaffner and Jacob Delp.

${ }^{40}$ PA: September 15, 1930 and HVF: September 15, 1930.

41 PA: September 19 and 24 and October 6, 7, 15 and $21,1930$.

42 PA: November 4, 11 and December 5, 1930.

${ }^{43}$ Interview with Heinrich Sand.

${ }^{44} \mathrm{PA}$ : November 15, 1930.

${ }^{45}$ Interviews w1th Jacob Brauer, Jullus Hofmann,

Lu1se Ste1nmetz and Ludw1g Gunkel.

${ }^{46} \mathrm{PA}:$ November $14,1930$.

${ }^{47} \mathrm{PA}:$ November $8,1930$.

${ }^{48} \mathrm{PA}$ : September 30 and October 4,1930 and HVF:

October 8 and 29, 1930.

${ }^{49} \mathrm{HVF}:$ November $17,1930$.

$50_{\mathrm{PA}}$ : November $7,1930$.

51 PA: December 18, 1930.

52 HVF: November 17, 1930. 
53 Interview with Georg Herth.

${ }^{54} \mathrm{PA}:$ November 21, 1930; HVF: November 22, 1930; PGSP: November 20, 1930; T.P. 257-258.

$55 \mathrm{PA}$ : November 25, 1930; HVF: November 25, 1930;

PGSP: NOvember 24, 1930, pp. 259-263.

${ }^{56} \mathrm{PA}$ : November 28, 1930 and HVF: November 29, 1930.

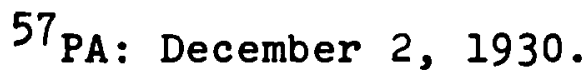

58 HVF : November 26 and December 2, 1930.

${ }^{59}$ PA: December 4, 1930.

${ }^{60} \mathrm{PA}$ : December 23, 1930; HVF: December 24, 1930;

PGSP: December 22, 1930, pp. 265-266. .

${ }^{61} \mathrm{PA}$ : November 29, 1930 and HVF: December 8, 1930.

62 HVF: December 8, 1930.

${ }^{63} \mathrm{PA}$ : December 10, 1930.

${ }^{64} \mathrm{PA}$ : December 11, 1930.

${ }^{65}$ PA: December 2, 1930.

${ }^{66}$ Interviews with Lud: ig Wenz, Lu1se Steinmetz and Adam Ruckelshausen.

${ }^{67}$ PA: December 10, 1930. 


\section{PART II}

THE EROSION OF REASON

1931 To 1933 


\section{CHAPTER VII}

A NEW NORMALCY - JANUARY, 1931 TO JULY, 1931

1931 began as unreassuringly as 1930 had ended. The very first days of the new year brought the unwelcome news that the Kreisamt had declded to Impose the hated beer and Bürger taxes upon the hardpressed c1t1zens of Pfungstadt. ${ }^{1}$ The Krelsamt's action unleashed yet another round of discussion among the ranks of the town cltizenry and in the town counc1l where one beleagued member exclalmed, "Why can't they work as quickly to cut expenses?" ${ }^{2}$ Expenses there were apienty in Pfungsiadt. The town counc1l which met on January 12 tad to hear reports of a large growth in unemployment. It was reported that over three hundred people had completely used up their national and county welfare payments, which placed the burien directly upon the shoulders of the town counctl. Sagging shoulders they were since the one hundred thcusand mark appropriation placed in the budget had long since been used up. Even a six percent cut in the paychecks of all of the town's officials on January I did not dent the hard wall of problems which faced the council. Added to the disquieting prospect of ever higher expenditures for the unemployed was Huxhorn's continued insistance that the counc1l Immediately take a 
position on his call for dissolving the council. ${ }^{3}$ The Christmas and New Years spirlt simply had not penetrated his one-track mind.

Huxhorn's wishes were finally acceded to on February 2 when the counc1l agreed only a council vote would settle the issue. A short, but intense, debate preceded the actual vote. Then a hushed quiet filled the chamber as the counc1i began the process whlch struck at the very heart of the council's authority. No spontaneous cheers filled the chamber as the mayor announced that the KPS's long threatening storm was no more than a light shower. The KPD could muster only the1r own (two) votes for the proposition while the SPD (eight votes) voted in a block against the measure. The bürgerlich abstained from taking sides. And as if the council were not devided on enough 1ssues already, the bürgerlich Insisted that the council again protest to the proper authorities concerning the beer and Bürger taxes. The salve such ointment gave to the hearts of the midale class was only equaled by the futility of their exasperated action. The council itself dutifulIf untted against the beer and Bürger taxes by voting unanImously against them, but their action had no iegal force. 4

Besides the KPD, the NSDAF would have stood to gain the most from the dissolution of the town council. This was one of the main reasons that the bürgerlich could not agree to unite with the KPD long enough to tighten the 
grip the extreme parties were tightening around the throat of the democratic process in Ffungstadt. The NSDAP itself had nowlere near the meniership that its electoral strength would have indicated. The $\mathrm{SA}$ could still only claim a pltifully smali number of adherents--ten or twelve at the most. 5 But the lack of numbers did not stop the party from staging another large public meeting. Late in January the party announced that the public was invited to a Sprechabend which would feature a discussion of the top1c "International Marxism or National Socialism." 6 The hopla that surrounded the event yielded few results. The working class was too hostile to the Nazis to attend while the midale class members of the party often wore their party pins under their coat lapels. Overwhelming public support for the Na:i party did not exist in Pfungstadt, but this only hid from public view the favorable opinion in which more and more individuals held the group. Outside of the 1928 debacle the NSDAP had not staged one parade or march through the streets of Pfungstait. All of that changed when the NSDAP announced that they would hold another public meeting on February 8. They formaliy proclalmed that Jahnke (Etville) would speak about "H1tler or Severing" in the restaurant "zur Traube," with the admission charge set at thirty prennigs for the employed and only ten pfennigs for the unemployed. The handbills an- 
nouncing the event appeared on the streets of Pfungstadt on February 7 , with a curfous reaction. The working class reacted is if they had ne: er been deepiy divided and at each others tinroats. The new Schutzgruppe of the Reichsbanner was folned early on the morning of the elghth by the members of the KPD's "Anti-facist League," giving the workers well over fifteen hundred men in the streets. The Nazi threat at flrst seemed to be the exact medicine needed to heal the deep festering wound within the ranks of the working class. The flags that fluttered in the breeze and the songs that floated in the air produced an Impressive sight, but did not deter the Nazis from gathering at the train station to greet their comrades from other towns at four thirty in the afternoon. The small contingent of local party faithful saw their ranks grow almost to three hundred strong when the Infusion of outslde blood was complete. With one ear cocked for potentlal trouble, the Nazis marched of to their meeting only to find a few frightened souls ready to listen to their message. But outside the restaurant shouts of derision continued to flow from the mouths of the assembled workers. The amazing turnabout with the contingent of the workers led so far that both the Relchsbanner leacer Albert Wäike and the KPD leader Huxhorn agreed to share a hast1ly erected stage and speak to the crowd. In short direct speeches they promised the workers that they would unite, and fight the 
common enemy--Nazism. With over elghteen hundred host1le Individuals assembled within easy striking distance of each other the six man police force of Pfungstadt was totally unable to meet any threat. The discretion and common sense of the police led them to call in reenforcements--the Schupo (Schutzpolizeit of the state to calm the troubled waters of danger which existed. Within half an hour three truck loads of Schupo had arrived at the scene. Their presense the Anzelger later wrote was responsible for malntalning order when danger seemed so close at hand. At the close of the Naz1's meeting the Schupo escorted them back to the train station. Although a flght did not break out, a few rocky inissles were launched from the working class crowd at the departing troops of the NSDAP. The verbal abuse was even more intense than the barrage of rocks, a fact that was not lost on the curlous heads which peaked out from behind partially opened windows. ${ }^{7}$ The quick arrival of the Schupo, together with the cool-headed handing of the crowd by the leaders of the NSDAP, the SPD and the KPD succeeded in restraining any amb1tion the hotheads in each camp had to break each others heads. For the flrst time since 1928 the Nazf party had succeeded in focusing the spotlight of attention upon themselves to the exclusion of other interests. In the following days the NSDAP spread the report of halr-tingling threats being made against their people. ${ }^{8}$ They attempted 
to stimulate the opinion that they were suffering at the hands of the SPD and the KPD because of their outspoken orposition to the existing state of affaps in Pfungstadt and all of Germany.

Events had not faded much before the SPD held thelr annual general meeting. Following a sharp blast directed at the NSDAP for their provocative behavior earlier in the day, the assembled worker's heard reports from their offlcers. The treasurer announced that the treasury was in poor condition because of the massive unemployment which sapped the fiscal power of the membersh1p. The chairman stepped in front of the crowd Immediately after the treasurer had concluded to reassure the crowd that the membership of the party had remalned stable, nelther increasing nor decreasing over the past year. W1th that business taken care of the leadership called for elections to the governing committee with the following results being reported:

$$
\begin{aligned}
& \text { Chairman - Georg Sinner } \\
& \text { Treasurer - Phillip Stock } \\
& \text { Secretary - Anne Gilbert }
\end{aligned}
$$

In addition to these posts Michael Hechler, Peter Crößmann, $S$, Grüning, August Hechler (no relation of $M$. Hechler) and $c$. Crobinann were slected to represent the membership on the party's governing commitiee. Only a further call for each member to assume more of a duty to the party de-, 
layed adjournment. 9 In 1931 the party assumed more of a youthful image than ever before. The orlginators of the party and the old guard were slowiy relinquishing thelr control of the party to younger members. The party leadership gained a mixed composition of young ideas and older maturity.

The Associated Union was also moving toward a more forward looking image. They had begun the process in January by launching a political education course and providing a speaker to explain accident insurance. The retention of the incumbent chairman, Peter Crößmann, for another year, indicated that KPD charges concernirg an unresponsive leadership were infounded. Another meeting was sponsored by the Union on February 27, where a continuing discussion of various insurances wert on. ${ }^{10}$ In addition to the Union and the SPD, the SAJ sponsored their own function on January 27. The far ranging forces of Social Demccracy were all called into play as the tension, fear, danger, and uncertainty mounted. The SAJ heard a speesh by Drott (Offenbach) challenging them to build a critical outlook in their search for the truth while they remained disclplined members of a large movement. A fourth element was also introduced into Pfungstadt as the Reichsbanner took on the responsibllity for actively portraying strength of the SPD in the streets of Pfungstadt. On February 22, a. Sunday, the Reichsbanner 
was scheduled to celebrate its seventh anniversary. In order to avold any possible trouble both the NSDAP and the KPD had been forbidden to march in Krels Darmstadt by the Hessen State Police on Saturday and Sunday (February 21 and 22). The1r precautions produced a tranquil atmosphere during the entire celebration, which was marked by a parade of over one thousand men into the town at 4:00 P.M. They assembled at the town hall to hear the over-all leader of the Reichsbanner in Hesse-Darmstad, Stock, defend the activities of the group and proclaim their loyalty to the state and the constitution. 11

Banning KPD and NSDAP marches over the weekend did not deter the Kommunale Wähler Vereinigung from continuing thelr plans to hold a protest meeting the same day of the Reichsbanner march. The first order of business were reports by a number of council members. They told the assembled throng that thanks to the efforts of the Bürgerliche Verelnigung the taxes of Pfungstadt's cltizens were not fifty percent higher. Over two hundred people attended the gathering, applauding the words of hope they had so lorg mj.splaced. One speaker boldly described the new Kommunale Vähler Vereinigung as "a party of all the people, without regard to religion, political affiliation or profession," dedicated the protection of middle class rights and interests. The meeting which occurred without incldent adjourned after a two mark a year $f \in e$ was agreed 
upon as dues. ${ }^{12}$ The Kommunale Wähler Verelntgung had again stolen the thunder from the NSDAF by taking a position on town affalrs which was not only popular bui very much desired. While the NSDAP sought out a discussion of International issues, the KWV punched away at the 1ssues of the moment.

Pfungstadt's farming comnunity had been in uproar since January when a disagreement broke out between the farmers and the blacksmiths over prices. The mayor stepped into the fighting as an arbiter and was able, with diplomacy, to moderate the tension which existed between the two parties. ${ }^{13}$ The farmers of Pfungstadt exercised more than their fiscal discontent during the first quarter of 1931. On February 28 the Landbund attempted to breathe some life back into their organization by sponsoring a speech--"The German farmers fight for freedom"--1n the "Rheinische Hof" restaurant. Even the Junglandbund also became involved, but showed signs of even more advanced nostility to the existing economic difficuities. ${ }^{4}$ The damage to the Landbund's structure was already extensive --almost unrepalrable, for many farmers belleved that the Landbund was too small and Ineffectual to influence national issues significantly. Some farmers had shown an early incilnation to search out a more effective volce for their grievances. The traditional national middle ciass parifes had shown no great interest in winning the anxious 
farmer to their cause, and since the farmer held the SPD and the KPD for traditional enemies, they really only hud one way to turn. The one party whlch offered the farmers an alternative with which they could live were the Nazis. The NSDAF had won the respect and the support of the Landbund when they had jolntly worked for the repeal of the Young Plan, thus it was falrly easy for a farmer to see the rising star of Nazism as their only salvation. The farmers did not march into the arms of the NSDAP en masse, although a large group were certalnly members by the Spring of 1931. To join the ranks of the Nazis ald not involve the average farmer in a long soulsearching process; he had too much to involve himself in on his farm to enjoy the luxury of intricate philosophical agonizing. The world of the farmer revolved around days filled with unending labor and worrying about the prices he would recelve for his crops and animals. For the most part, farmers were relatively secretive about their political undertakings. 15

A good indication of the tone the political atmosphere in Pfungstadt, as it existed since the beginning of the despression, is provided by a small articie which was inseried in the Anzeiger on March 6. Phillip Stark, a baker, "warned" the people of Prungstadt not to believe that he had ever sald anythine against the KPD. He emphatjcaizy declared that he had never made any statement 
against the KPD and threatened to take anyone that accused him of such remarks to court. 15 Stark's troubles provided a token of the power of the working class, and one of the reasons why secret membershlp in the NSDAP was such a prudent action for the businessmen of Pfungstad. The conditions of normalcy had changed vastly in the space of only three years. An unmlstakable cloud of susplcion hung like a heavy welght over Pfungstadt.

As the ordinary citizens of Pfungstadt wrestled with their individual frustrations and fears, the town counc1l dealt with the ever-increasing financlal problems unemployment forced upon them. The town was committed to supplying the unemployed with funds which totaled four thousand thirty-one marks per week durling March. This horrible dilemma was coupled to the fact that the town could use only thirty men for woodcutting in the town forest. The rest of the unemployed were left to forage for themselves. Most found nothing to do but sit on Pfungstadt's sidewalks and mutter unpleasant (and sometimes foul) remarks at business people and the members of their families as they passed by. 17 Recriminatory exchanges were not a new phenomenon in the chambers where the town council met. Before tackling the intricate problem of the Kreisamt's report, the council meeting of March 30 had to handle the problem of finding more jobs for the unemployed. Only efichty places could be found after a liveiy discussion 
ended, but the problem did not end there for many unemployed men simply went into the woods to gather their own wood whether it was legal to do so or not. The unauthorlzed practice of desperate men gave the middle class the opening they were looking for. Since men workIng in the town's forest were considered offlcial employees while they were at work, the bürgerlich moved that the Krelsamt's report recommending lower wages for officlals be adopted without change. In a time when everyone was suffering some form of financlal difficulty, they argued, offlclals should not recelve excessive remuneration. The SPD and the KPD took a different point of view. They disputed the fact that the Kreisamt had supplied the council with a clear solution to the complex fiscal encumberments of the town. When the matter went to a vote the bügerlich found themselves short of the necessary number of votes to adopt the report. ${ }^{18}$ This setback did not deter them from adhering even more tightly to the Krelsamt's suggestions. As they left the council chamber they vowed to stage a mass protest meeting of the Kommunale Wähler Vereinigung. A rumor that a blcycle tax would be imposed in addition to the beer and Bürger taxes only added fuel to the fires of suspiction which characterized the political atmosphere. 19

While the NSDAP and the traditional inidaie class 
parties attempted to recruit additional support, the Kommunale Wähler Vereinigung was solidifying a solid force of disinchanted midile clasis citizens behind their movement. On Aprii 11 an impressive contingent of middle class voters gathered together to hear "Why must our [town counc11] officlals adopt the report of the Krelsamt, and how can this come about." Taxpayers and especialiy women were invited to come and hear KWV speakers accuse the SPD of dealing in theory, not in practice. An involved explanation of the path the Kreisamt's report had taken was followed by a scathing denunciation of the SPD for falling to heed the wishes of the business commun1ty. 20 An exaggerated sense of doom slowly spread 1ts tentacles over the assembled throng. Only the KWV promise that they would energetically seek to reverse the situation seemed to ease the feeling. The dynamic thrust of Stetnmetz and Martin returned to many c1tizens the trust that someone cared for their problems, and made the two the most popular agents of middle class resentment. Common, everyday actions, such as the KWV's tax information bureau, took on a whole new significance for a class which felt its old established soclal and political practices dissolving before their eyes. The reaction of the KWV to the pressing flscal quaginire was uniformly vlewed as a constructive alternative to the generally misunderstood (thus hated) SPD economic pronouncenents. 
The fact that middle class cltizens saw the Kommunale Wähler Vereinigung opposing the status quo while they projected the image of thrift,ness (Sparsamkeit) and order, lent them more and more the leading position in Pfungstadt's changing political scene. The DVP, one of the strongest political factors in Pfungstadt before 1929 borrowed the call for economy in government in order to regain some inftiative among the voters. Hofmann announced that Dr. Nlepath (a Landtag member) would use the theme, "Community tax policies" as the basic for a discussion of financlal policles. The crowd which responded to the DVP call was respectable, and IIstened to Niepath's long speech concerning the necessity for income to equal expenditures silently. He stressed that savings would accrue only when taxes were lowered. 21 Unfortunately the DVP could not master the intricate forces which stimulated midale class citizens to demand a fundamental reordering of fiscal priorities. People wanted calm and their old ways again. The DVP could not find the formula which wolild combine older prejudices in a new package. They reacted to change; they did not master it.

In a period which put a premium on new impulses to defend old Institutions, the Relchsbanner had to spend a considerabie amount of time explaining their goals to a working class seething with unfulfilled hopes and aspirations. On March 38 the Rejchsbanner called in Behoven to 
demonstrate to their constituency that the purpose of the organization was to combat extreme excesses. Members of the Relchsbanner were not the only crowd that was arawn to the meeting. Huxhorn put his magnetic speaking ability to use by calling the Reichsbanner a fraud. His attack was directed iess at Individual Reichsbanner leaders as to his contention that the only group that would really stand up to the Nazis in a physical showdown was the Anti-facist League of the KPD. Albert Wälke charged Huxhorn with dividing the working class, and reemphasized the nationwlde resources of the Relchsbanner. ${ }^{22}$ To neutralize the momentum of the KPD, the SPD asked for the mayor of Darmstadt, Delp, to give his views concerning "Politics in the Hessen Landtag." His words of encouragement and the large crowd he drew balanced the rhetorical theatrics of Huxhorn. To single out the opposing parties more clearly In the minds of the SPD electorate Carlo Mierendorff appeared at an April 16 SPD rally, addressing himself to the theme, "The Reichsbanner, the KPD and Facisin."23 To insure that order would prevail, it was announced that the Relchsbanner would act as a protective force at the meeting. This measure was intended to be a timely reminder to the KPD that they could not create disorder at SPD gatherings. The warning was occasioned because of a KPD outburst during an Associated Union meeting late in March. Erößmann had announced that Bernhardt (Offenbach) would 
discuss "The truth about Russia." As the KPD caught sight of the speaker at the meeting they broke into a chorus of "voos," continuing to neckle him throughout his remarks. When cröBnann ordered the offenders expelled from the hall a pushing match broke out and quickly alssolved into a near riot. The poilce immediately stopped the meeting and called for the Schupo, but not before several black eyes had been recorded. By the time the schupo arrived at the scene of the altercation, only a crowd was still loitering about in front of the hall. 24 The personal abuse and name calling that was tossed back and forth between the KPD and the SFD only weakened the power of the workers to face the challenge the midale class provided.

Holding the allegiance of the unemployed was a primary task for the Union. One means at the disposal of the Union was their unemployment bureau which handled over one thousand cases in 1930 for people who did not understand their rights. The rewards for the effort was a small response to the KPD unions. Switching to the attack the Union tried to stem the drift to the KPD with a more direct assault on the existing financial situation. On April 17 they sponsored a meeting to discuss "The German working class's fight for freedom against the reactionary capitalists and their supporters."25 The speech was ained at holding the workers together under the banner of the Unfon. carrying on the theme of unity, the leadership of the 
Union fostered the slogan "Up with the old solidarity" for the annual May Day parade. Coupling the militant new Ine of the Relchshanner to that of the Union, the May Day march got under way right on schedule under the warmIng rays of the sun. Desplte the activity of the KPD's Revolutionary Union opposition during the latter part of Apr11, the vast majority of the workers stayed within the ranks of the Union on May 1. They heard speakers stress that only the old unity of the workers would produce constructive results. Huxhorn had accentuated his opposition to the existing system of uniorism during an impassioned speech to a respectaile crowd the same day. ${ }^{26}$ The competition for the hearts and minds of the working class was a challenge for even the most experienced union man.

The zeal of the Union and Reichsbannej leadership did not wane after May 1. Early in June the Union reminded the membership that Brüning's emergency decrees were particularly hard on the workers. The assembled membership was also indlgnant that one of thelr colleagues had been fired by the farmers' milk cooperative because he was a busy part of the Relchsbanner. 27 The Reichsbanner itself had taken on a greater responsibility for the area surrounding Pfungstadt. On May 31 over four hundred Relchsbanner colleagues marched to the nearby town of Eberstadt despite an official state ban. Returning to Pfungstad, the Relchsbanner paraded through the streets led by a 
band to a prearranged plcnic area where a family fest was held. The Relchsbanner was again active toward the end of June, when a membership mesting wcs held. It was reported that the greatest part of the Reichsbanner was made up of unemployed men who had used up their state and national welfare payments. A main topic at the meeting was Wälke's denial that a number of Reichsbanner people had defected to the KPD's Anti-facist League because the Relchsbanner was not militant enough. 28 Those charges were to be refuted sooner than anyone would have belleved. The Nazi group in Pfungstadt could not hope to rule the streets since the workers could easily outman them in any conceivable situation. Thus the pent up fireworks lodged In the hearts of many dissatisfied men exploded in the streets of Escholibrücken, a small farming settlement three kilometers west of Pfungstadt. Violence burst forth because of two of Pfungstadt's Reichsbanner people had been marhandled at a NSDAP meeting in Crumstadt a few nights earlfer. The Reichsbanner had been informed that the two men were held In the cellar of the Nazi headquarters for the night. Tempers were at the boiline point, even as the Nazis marched ir.to Eschodlbrücken for their gathering. Two hundred Reichstanner and KPD members greeted them with cat calls and other insults. The NSDAP people retaliated in kind, only to find the level of violence ralsed a notch. Individual duels broke out all 
over the street with the Nazis coming out the worse for their efforts. 29 The tension filled air hung over pfungstadt itself ror some weehs after the confrontation in Eschollbrücker. The back streets of Pfungstadt resounded to the shouts and insults of protagonists for weeks, but only an occasional SA member ventured to back his words with his fists; and then quite often with a disasterous outcome for himself. The workers ruled the streets.

Physical violence had not reared its ugly head withIn the town counc1l chamber, although the heated exchanges which often took place seemed to hold out the promise that such an event might have to be reakoned with. At the June 22 town council session the sad news that the SPD plans to spend fifty thousand marks constructing streets would have to be drasticaliy cut was announced by Mayor Schwinn. Only sixteen thousand flve hundred marks would be allotted to pfungstadt under revised state plans for guaranteelng such loans. The SPD's plan to reduce dangerous tensions by putting men to work at usefui jobs was shattered. To add Insuit to Injury Martin Immediately demanded a complete check of the unemployment roles so that loafers might be eliminated. The fact that the town had to appropriate over four thousand marks per week for the three hundred individuals whe had a right to support from the town only lent additional emphasis to the cries from all sldes to resolve the matter of jobs. ${ }^{30}$ At the very 
time when the counc1I needed to unite its energies and solve the massive problems facing all of the town's cit1zens' devisive Impact of the depression increased. At the sixty-ninth annuai meeting of the Voiksbanks the directors reported that for the first time in years the total amount of deposits had decreased markedly. A judiclous application of sound financlal policy insured the bank's stability according to the Anzeiger. 31 Yet to the business community and the average citizen an increased feeling of uneasiness lurked behind the smooth words.

Pfungstad's unnerving fiscal difficulties, together with the struggle life had become for most cltizens, truly made the flrst half representative of the new normalcy which stalked the streets. Beyond the negative spirit the times engendered in the town, people were beginning to ask for new answers for new forces to mold their insecure exIstances into more advantageous channels. That was exactly the new normalcy--the people of Pfungstadt started to concentrate their attention on the extreme parties, hoping to find relief in the promises that were banaled about. The new standard bearers of the time: fear, insecurity, and outright hatred, mark a ripening of the forces which were unleashed in 1928/29. These soldiers of destiny had assumed their own dynamic, and they were leading the people of Pfungstadt into the uncharted waters of political adventurism. 


\section{CHAPIER VII - FOOTNOTES}

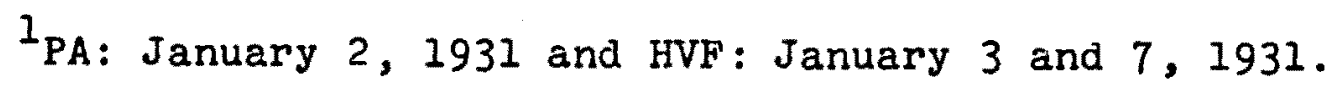

2PA: January 15, 1931

3PA: January 12, 1931 and PGSP: January 12, 1931 , pp. 267-269.

${ }^{4} \mathrm{PA}$ : Fetruary 3, 1931 and PGSP: February 2, 1931, pp. 270-271.

${ }^{5}$ Interviews with Helnrich Schaffner and Wilhelm Kaffenberger.

${ }^{6}$ PA: January 29, 1931.

7PA: February 7, 1931; HVF: February 10, 1931; notes from the file of Hans otto.

${ }^{8}$ Interviews with Heinrich Sand and Jacob Hanbuch.

$9_{\mathrm{PA}}$ : February 7, 1931 and HVF: February 12, 1931.

${ }^{10} \mathrm{PA}$ : February 17, 1931 and HVF: January 12, 1931.

11 PA: February 22, 1931 and HVF: February 22 and March 5, 1931.

12 PA: February 24, 1931.

13 PA: January 15 and February 27, 1031.

${ }^{14} \mathrm{PA}$ : February $27,1931$.

${ }^{15}$ Interviews with Ludwi.g Gunkel, Peter Crößmann and Julius Winkler.

${ }^{16}$ PA: March 6, 1931.

${ }^{17}$ Interviews with Ria Hanbuch and Jacob Brauer. 
${ }^{18}$ PA: March 31, 1931; HVP: Apr11 1, 1931; PGSP: March 30,1931 , pp. 282-283.

19:A: June 16, 1931.

20 PA: Apr11 4 and $10,1931$.

${ }^{21} \mathrm{PA}$ : May 4, 1931.

${ }^{22} \mathrm{PA}: \operatorname{Marcs} 17,1931$ and HVF : March 23, 1931.

${ }^{23} \mathrm{PA}$ : Apri1 15, 1931 and HVF: April 18, 1931.

24 PA: Apri1 11, 1931 and HVF: Apri1 10 and 11, 1931. ${ }^{25} \mathrm{PA}$ : Apr11 15, 1931.

${ }^{26} \mathrm{PA}$ : April 29, 30 and May 2, 1931 and HVF: May 2, 1931.

${ }^{27} \mathrm{PA}$ : May 30, 1931 and HVF: May 30, June 1 and 2, 1931.

\section{${ }^{28}$ Ibid.}

${ }^{29} \mathrm{PA}$ : June 2, 1931 and HVF: June 5, 1931.

30 PA: June 23, 1931; HVF: June 24, 1931; PGSP: June $22,1931,292-295$.

${ }^{31}$ PA: Apr11 19, 193I. 


\section{CHAPTER VIII}

REACTION TO THE DEPRESSION - JULY, 1931 TO JANUARY, 1932

In the minds of a growing legion of middie class voters (also in a significant portion of the working class) was the 1dea that only a wholesale reordering of the political power structure in Pfungstadt could save the town from the depression. The old ways had to be changed. This addictive serum, first infected into the economic veins of Pfungstadt's soclety, steadily gained a wlder following as the last half of 1931 unfolded. As the deadly toxin flowed more and more to the minds of the normally subdued and rellable sectors of middle class influence, the siren call of Naz1sm grew to a roar. While the town counc1l dutifully played out its role of supreme arbiter of Pfungstadt's affàis, the entangling net of Nazl power grew, lurking behind the sood names of many cltizens, revealed to the bright rays of the sun only on election day. The powers which attempted to oppose this creeping menace were ensnarled in their own struggles or blocked from viewing the Insidious strength of the movement. Thus the casual observer of Pfungstadt during the second half of 1931 often only saw anxlety where despalr had become the order of the day. 
The political currents of discontent were running very strong within the town councll as the budget debate b-gan. Cn July 16, the very day the debate was to begin the Kommunale Wähler Vereinlgung publicly staked out its position with regard to the budget. The Anzelger noted that the KWV intended to press for: I) a substantial cut In the paychecks of town officials, 2) a revision in the town's responsiblifty for providing apartments for the poor, 3) the reduction in official positions in the town's administration (Including one policeman), and 4) the application of the savings thus accrued to balancing the unemployment welfare subsidy so that taxes would not be increased. ${ }^{I}$ The position of the $\mathrm{KWV}$ had been reenforced by a pronouncement of the Handwerder- und Gewerbeverein that they were without funds to participate in the annual Cattle Show with an exhibition of their own. They noted that the crafts needed the support of the counc1l if they were to even survive. ${ }^{2}$ Thus as the town counc1l opened 1 ts deliberations the evening of July 16 they had been forewarned that a solid unit of middle class representatives would work for minlmizing taxes and maximizing savings. When the appointed hour arrived for the council to Inftlate its discussion of the budget, every counc1l seat was filled and a large contingent of spectators were on hand. After the mayor accepted the budget proposal of the inance commlttee formally, the exchange of opinion 
began in earnest. The first hurdle was set firmly in place when the KWV representative, Martin, introduced the KWV's measures. He demanded that the council arrive at the logical position and reduce the pay of the town's officials. His words were met with firm resistance from the SPD side of the chamber. A SPD man pointed out that the town had already discharged its duty to its citizens since Brüning's emergency decrees had effectively cut take-home checks by twelve percent. The opening rounds of the council's annual marathon of verbal fisticuffs had gotten off to the expected start. With the agreement of each of the parties which were represented in the counc1l, the mayor ordered that each point in the budget would be discussed in turn, but that a vote would only take place after the counc1l had studied the entire budget. He hoped to save the councll the overzealous met1culousness which had plagued the seemingly unending debate a year earlier. But his enlightened suggestion could not drive the words of scorn which were regularly marketed for public consumption from the council entirely, nor could it bring reason and understanding to minds which were filled with fixed positions and feelings of self-fulfilling righteousness. Time and again the KPD set itself squarely against the measures of the middle class representatives. Huxhorn again proposed that water and electricity prices be staggered in relationship to a family's income. He also took 
extreme exception to the $\mathrm{KWV}$ motion to increase rent on town-held apartments. He submitted instead a plan to lower the rates.

Gräff (NSDAP) asserted hImself to a greater degree than ever before. H1s recommendation that the town's contribution to the Workers' education committee (SPD) be halved succeeded in elfciting howls of protest from among the SPD block. A classic example of the heights of irresponsibility some members of the council had succeeded in scaling is provided in regard to their proposals for the police force. The KWV had suggested a one man reduction in the police force, the KPD was ready to outbld their opponents by proposing that the entire police contingent in Pfungstadt be done away with. ${ }^{3}$ A stampede of stunning propositions was seeking to push the counc1l toward a situation of utter hopelessness. Events were not altered even one degree in the July 20 meeting. By the July 23 councll session voting commenced on each point in the budget. Another predictable situation developed, as the SPD folned forces with the middle class or the KPD to defeat each dangerous motion as they appeared. The wages of the town's offlcials was not lowered because of KPDSPD votes, while unemployment compensation rates were not doubled because of SPD-middle class action. The main stage of public opinion had been cleared for a decision concerning the entire budget. The preparations need not 
have been so grand, for the council divided on the issue of the budget just as it had one year earlier--a ten to ten standoff--defeated the budget. Martin, speakir:z for the middle class, hastily expressed his opinion that his block's negative vote was based on the premise that the town's officials recelved too much remuneration for their efforts. Huxhorn, the appointed spokesman for the KPD, declared that his party's soclally just measure had recelved too quick a hearing. His party would not approve a budget filled with anti-social notions and phoney economy. (The SPD did not make a statement. ${ }^{2}$ ) The yearly stalmate of the counc11 once again popped up, but this year with only a faint glimmer of relief in sight for Huxhorn had no unfinished prison business to bother him.

The only cause open to the council was to drink deeply from the fountain of faint hopes and then plunge back Into more deliberations four days later. The members of the councll must have swallowed deeply of the fountain's waters for at the July 27 councll session agreement of sorts was hammered out. Four days had been a sufficlent period to allow the haze of contradictions to be lifted from the eyes of the SPD and the bürgerlich--long enough for them to settle on an orderly alternative to financlal anarchy. The SPD and the mlddie class representatives had taken the almost unheard of step of conferring with each other. They consented to accept the outcome of a court 
challenge on the extent to which the town would pay its workers. With the two sides collaborating during the short cease-fire, and the KPD pcintedly avolding the councll chambers, the $1931 / 32$ budget was accepted. 5 Th1s sensible answer to the threatening clouds of extremlsm produced a budget almost Identical to the previous one. Taxes would remain virtually unchanged since the estimate of needed income was within one thousand marks of estimated expenses. One immedlate threat to the town's baslc fabric had been turned back. Unfortunately, no one was really satisfled with the budget. No one had squeezed from the counc1l acceptance of thelr objectives. The KPD made good use of the fact that the SPD had votes with the bürgerlich to defeat measures for the benefit of the working class and the unemployed. The middle class, particularly the Kommunale Wähler Verelnigung, could claim that they had saved the middle class from the imposition of new and more taxes, while at the same time they were blasting the SPD and the KPD for jolning hands to defeat even more amb1t1ous plans to cut the budget. The SPD was left with the middle ground exposed to random assaults from two sldes. They stood proudly in the middle, trying to balance the wishes of the unemployed agalnst the abllity of the ddle class to pay. It was a lonely position that promised the SPD no polftical reward in a political. system which was splitting itself wide open. 
The most notable effect of the depression upon Pfungstadt was the growing cadre of unemployed men. By July the unemployed numbered approximately elght hundred, the town being responsible for three hundred and fifty of the elght hundred. During the $1930 / 31$ budget year relfef to the unemployed had cost one hundred fifty-elght thousand seven hundred and s1xty-s1x marks. Budgeted for $1.931 / 32$ was a similar surn. 6 (See page 464 for a complete breakdown of town unemployment compensation payments.) Many men felt a very real shame of being unemployed while middle class cltizens worrled about falling into the same situation. In the case of the middle class businessman he could always fire his employees and make due with the members of his family. This tended to hold the unemployment devil from his door, but a very real drop in income was experienced by the vast majority of the middle class. 7 This led both the man directly affected by unemployment and the man who felt that he might become unemployed to call ever louder for a way out. As the depression grew in ferocity the crles became increasingly shrill and the extreme positions became more appealing.

Against this deteriorating backdrop the Constitution Day celebration was staged. For a second year in a row the KPD and the bürgerlich had jolned forces to stop any town appropriation for the festivities, and for a second year in a row the SPD assumed the responsibility for the 
event. The Relchsbanner announced that it would bear the burden of organizing the event. The town administration coperater as best it could by ordering all officlal bulldings within its jurlsdiction to fly the black-redgold flag of the republic, whlle the Protestant church minister agreed to hold a speclal service and ring the church bells for a quarter of an hour at noon the day of the parade. A sair number of clubs had announced that they would particlpate in the annual march, but the weather on the day of the event falled to fit into the plans of the organizers. It rained very hard on the appolnted day; nevertheless a respectable crowd listened to the local teacher, Winkler, proclaim that the Welmar Constitution was one of the best in the entire world. Mayor Schwinn seconded Winkler's thoughts in a short speech of his own, laying particular emphasis on the town of Prungstadt preserving its own freedom within the rules of the constitution. ${ }^{8}$ The KPD had taken exception to the entire proceedings, expressing their own 1deology to the putilc through a series of propaganda slogans which were painted on varlous streets throughout the town. 9

The combination of increased political differences and the ever deepening depression spurred more men to vent their anger on the bodies of polltical opponents. Barely four days after Constitution Day a fight was reported between several KPD and NSDAF members in front of a tavern. 
The burgeoning militancy, both propagandisticly and physically, made the KPD a very real party to reckon with. But far from the hanhazard efforts of political novices the KPD was well organlzed and very, very well led. As one high ranking member put it:

The KPD was a party with an ldeological program which clarifled our aims concerning the workers and the common people, not a party of terror and trouble makers. Those aims gave us a certain character. We were against poverty, against the rich, and against those who sought to soak the poor. We always tried to be helpful; we did not only conduct marches, we also founded an unemployment office in Pfungstadt. We tried to represent the unemployed workers because of the infustices perpetrated by the employment office [in regard to unemployment compensation]. Our propaganda program considered not only the average citizen but also the whole unemployment system. Our representatives in the town counc1l always stuck up for the downtrodden. If necessary we were wllling to go into the streets and in open discussion to clarify matters which had been debated at meetings. Our main slogan always was, 'we, the poor, against the rich.' our alms and our actions brought us the trust of the voters. But whenever it was necessary (and this I want to emphasize) to counter facism with our fists, then we fought!10

As the depression deepened, the power of the KPD grew in direct relationship to hopelessness among the ranks of the unemployed. The election returns demonstrated that ract.

It is very likely that the strategic strength of the KPD would have grown even more if the SPD had not had a special traditional relationship within the working class. Through Minister Georg Raab and the Vice-mayor 
Welgel a traditional block of voters regularly placed their mark next to the SPD name on the ballot at election time. Trust and tradition helped the SPD a great deal during the dark days of the depression. 11 In addition to the old line supporters the party attempted to win new members through a variety of meetings, hanab1ll distribution, interest groups and clubs. One of the most active clubs during the entire perlod 1928-1933 was the SAJ, the SPD's youth group. One and one-half years of dogged determination was rewarded on July 12 when the group opened a new Helm (club house). Located on a plece of property the town had sold to them, bullt with materials which had been taken from an abandoned bullding the French had left behind at their crieshelmer camp, transported and reassembled in Pfungstadt by SPD, SAJ and Union members, the building assumed an Important place in SPD propaganda efforts as an example of positive accomplishment as opposed to mere rhetorlc. In conjunction with the opening of the Heim, the SPD sponsored a parade, concert and picnic. The ma1n activities were held on Sunday, July 12 and attracted a sizable contingent of Pfungstadt's cltizens. 12 Even the bürgerlich expressed an admiration for the impressive effort that went into the project. Hesse-Darmstadt Minister-President Adelung (SPD) and others spoke with pride of the hope such undertakings gave to everyone. 
The inaugural presentation in the SAJ's Heim revolved around the serious message of "All quiet on the Western Front" wh1ch the Workers' Education Commlttee staged. The show consisted of elghty slides from the film. The event was such a success that Georg Lieb1g transported the slides and equipment all over southern Hesse by b1cycle, piaylng to large audiences wherever he went. 13

August brought to the attention of the politicians In Pfungstadt the fact that a Landtag election was scheduled for November. The SPD jumped into a campaign posture early, holding the first meeting to discuss the candidates for the Landtag election and hear Mayor Lorenz (Erzhausen) glve h1s views on political developments the third week in August. ${ }^{14}$ Supplementing the regular party activities was the thirtieth anniversary of the Factory workers section of the Associated Union. The Factory workers section was the oldest part of the Union and vividly illustrates one aspect of the tradition which sustained the SPD through the challengling battles with the KPD and to a lesser extent the middle class parties. Another facet of the SPD's strength was the union which regularly sponsored meetings at which the unemployed could vent their grievences. One such meeting found a worker stating that "1t is hard for people in the prime of life to bear such overwhelming unemployment." 15 The leadership of the Union reminded their members once again that wild 
statements and demands would not solve the problem. For over two years the working class had patlently listened to the SPD's Iitany that inappropriate action would only precipitate a worsening of the situation. By the last half of 1931 a growing chorus of men (and their wives) were questioning whether a more radical solution might not be needed.

Increasingly the talk of all sections of soclety mentioned the urgent need for change: change from the existing situation; change which knew no goal, but only what it did not desire to continue to have. The average man had developed the habit of stressing the negative aspects of the current situation. The negative voter, the man who voted against the depression, became a flxture in the political landscape of pfungstadt. In the case of the workers, the KPD provided the outlet; in the case of the middle classes, the NSDAP stepped into the breach with a program composed largely of oppositional, negative statements in 1931. The strength of the NSDAP was certainly hard to determine in Pfungstadt, since the greatest portion of NSDAP propaganda within the middle class was passed from friend to friend, rather than being dished out at public meetings. The steady growth of the NSDAP among the respected middle class secton depended inItially upon the image they profected as a means of protest. Full fledged support had to walt for the depression 
to rlpen somewhat further. The NSDAP 1tself had changed fundamentally slnce its inception in Pfungstadt. Between 1.024 and 1928 a radical fringe had made up the bulk of the membersh1p. By 1929 a few 1nterested farmers and businessmen had begun to investigate the party, often coming away somewhat disturbed at the radical pronouncements of the "old fighters." By 1930 the party had attracted a sizable. protest vote in the Relchstag election. During the second half of 1931 the party began to move publicly to offer itself as a real alternative to the fears which the depression had spawned. Yet throughout the depression years the party meant many things to many people. The NSDAP itself falled in some instances to grasp the most beneficlal issues. They persisted in attempting to win the working class to their cause long after the working class voters had shown that they were not interested. On August 23 the NSDAPset about opening its own campaign for the coming Landtag election with a meeting featuring the "reformed" communist Felix Neumann (Wiesbaden) as the principle speaker. The KPD incensed at tactics, staged a march through the streets at noon, the day of the meeting. The NSDAP marched into their meeting late in the afternoon surrounded by twenty state policemen. At the meeting a varlety of KPD members, Union members and SPD members competed with the NSDAP group for control of the meeting. Neumann gave his speech, accompanied by a chorus of insults 
at strategic moments. Later in the meeting the SPD and Unfon members left in unison when Peter CroßBmann, the Ausoclated Union chairman, was not allowed to take part in the discussion. Huxhorn bellowed his own comments above the din of the crowd. With the police standing by in case of trouble, the crowded hall remained orderly. ${ }^{17}$ Polltlcal debts were pald off later in the week when the men gathered at their restaurants to discuss the complex issues of the day.

Undaunted by their less than frlendly reception by Pfungstadt's workers, the NSDAP moved to the farming front, scheduling a meeting September 6. A farmer from Baden scheduled a speech entitled, "Bauer in Not - Volk ohne Brot" (When the farmer is in need, the people will not eat). The toplc and the audience were more to the liking of a receptive section of Pfungstadt's soclety, but unfortunately the police stepped in and cancelled the meeting. The near miss they had had at the August 23 meeting of the NSDAP had been enough to convince the police not to take any chances. 18 Paralleling the banning of the NSDAP meeting in Pfungstadt was the order of the Interior Minister, Leuschner, banning the Nazis from wearing $S A$ and SS uniforms. Their children were also not to be allowed to wear H1tlerfugend uniforms. The ban went so far that any identifying mark of Nazi association was to be considered a violation of the law. Only a very few 
Individuals were affected by Leuschner's ban in Pfungstadt. Those that were used the Interior Minister's order to their own advantage. The day after the ban was issued Nazis appeared on the streets in white shirts. The net effect of the ent1re issue was to throw more support to the NSDAP since a large number of people did not think that the Nazls were any more gullty or wrongdolng in Pfungstadt than any other group. The Nazis themselves protested saying that they were being martyred for their bellefs not thelr actions. ${ }^{19}$ The KPD, they maintalned, should have been under ban. The SPD applauded the stand Leuschner had taken, while the KPD 1mmediately demanded that the NSDAP be banned entirely. All in all the Nazls definitely gained from the publicity they recelved for a measure which falled to strike at the organizational structure of the party. Limfted response to a potent1ally dangerous movement was not understood by a large segment of Pfungstadt's soclety, and in many cases the Nazls simply ignored the ban.

The SPD was definftely buoyed up by Leuschner's resolve. The leadership of the SPD had been altered slightly in the intervening period when the former SAJ leader, August Hechler, took over the post of cha1rman of the SPD early in September. ${ }^{20}$ His election completed the SPD's regeneration, and left the party free to call on the energy of 1ts younger members whlle it retalned the 
support of mature members of the movement. The new leader called for an election meeting on September 26 to acquaint the membership more fully with the SPD's plans for the Landtag election campaign. One instrument which came to play an Increasingly important role was the Reichsbanner. The Re1chsbanner marched through the streets of Pfungstadt on Wednesday, September 30 , in full force. At nine o'clock in the evening the march ended at an open meeting where Christian Stock ${ }^{*}$ spoke to the crowd concerning "Our fight against facism." As the supreme head of the Re1chsbanner in Hesse-Darmstadt his words carried a special meaning for the SPD. They wildly cheered his remark that "we republicans w1.l1 never surrender to the facists; we w1ll fight."21 A new day had dawned in Pfungstadt. Words of derision were replaced by words of warning. Clearly the NSDAP had assumed a new significance for the SPD; they had assumed an even greater significance for the disenchanted middle class voter. The new SPD leader continued his drive to thrust the SPD back into a commanding power-political position in Pfungstadt by robbing the extreme parties of 1ssues. On October 12 another election meeting was held. Paul Welgel, one of the grand old men of the party, reported on the political situation in Pfungstadt while the election committee gave out 
campalgn asslgnments to tested party members and urged the younger members of the SPD to f1ll their time with propaganda activities. 22

Stopping the NSDAP was to prove a most difflcult task. On October 18 the Nazis scheduled a public discussion of the goals and alms of the party plus a speech by Llebel (Zwelbrūcken) about "The road to freedom." The meet1ng came on the heels of the establishment of a Nationale Sozialist1sche Betriebs Organization until by Hans Otto In Pfungstadt. 23 The NSBO was directed at the workers; 1t was the Naz1 answer to the SPD's and KPD's unlons. The Nazl meeting flowed smoothly along slnce the Relchsbanner was attending a meeting of their own in a nearby town. Police were present at the Naz1 meeting to insure that no overeager KPD men would start trouble. Thus the pollce seemed to have everything under control. Even as the Nazis marched out of town no hint of trouble filled the air. Then from the ncrth appeared the Re1chsbanner in a truck and trailer returning from their gathering. W1th the Nazis from Pfungstadt and surrounding towns fllling the streets the truck had no alternative than to slow down as It passed through the crowd. What began as a barrage of scurrilous abuse soon turned into an exchange of rock throwling and flst flying. Blood was shed on both sides before the two groups could be separated. 24 Yet another brick had been plastered 1nto the wall of hate wh1ch more 
and more clearly divided citizen from cltizen. Added to the escalating physical danger which lurked in the hearts of many disgruntled inhab1tants was a report in the Hessischer Volksfreund (SPD) that two Nazi youths had accosted two old ladies in Pfungstadt and had virtually forced them to buy a Nazi paper. ${ }^{25}$, The somber tone which filled the article was matched by the growing awareness within the ranks of the SPD that the NSDAP was a force to be reckoned with.

A most striking result of the sad state of economic affairs and the consequent move to the extremes was the Instability of the traditional middle class parties to respond with programs and alms of the1r own. During the campaign perlod preceeding the Novernber Landtag election, the DVP was the only party to schedule a public meeting. The gathering took place only two days before the election, andstressed the role that the DVP had played in cutting expenditures and leading the fight for economy measures. Assembled in the Rheinischer Hof restaurant the party 1mported Mayor Nlepoth (Schlitz) for the occasion. ${ }^{26}$ But In the minds of many bürgerlich the DVP was considered too small for the task at hand. Having falled to achleve strong electoral support before the depression began, the party was robbed of the momentum which it would have needed to forge a middle class bond for action during the depression. The other middle class parties either met in 
the homes of their supporters out of public view or left the fleld to splinter parties. Pfungstadt heard only the Radikaldenocrat1sche Partel urging "the new left tc fight," and the Christlichsozlaler Volksdienst call for the renewal of christian middle class values as "the right way out of all of the troubles of our time." The Wirtschaftspartel flatly announced that it would not run any candidates in the election. 27 The sorry state of middle class political undertakings left the fleld all the more free for the proponents of extreme change to dominate the scene in Pfungstadt. Suddenly the SPD remalned the only party standing between two radical alternatives. Lackluster middle class politiclans left them no other cholce.

The SPD had never assumed that it would have to take on the role of defending democratic institutions alone. To be sure, the SPD had fought hard battles with the traditional middle class parties during the 1920's, yet all the pollticlans had belleved that basically they belonged to one state. Now that situation was changing. The extremes, who claimed to represent alternative state structures, were in the forefront of political struggle. Strange were the ways of politics in the 1930's. The Reichsbanner had to take on a role which it had never really anticipated flghting alone--protecting the institution of democratic government. The response of the Reichsbanner to the changing situation was firm and 
orderly. To stress 1ts preparedness to oppose extremlsm, the Relchsbanner set out on a march to the nelghboring town of Eherstadt. They extended thelr duties to Include the protection of SPD meetings, acquitting themselves very well in the process. ${ }^{28}$ The SPD met on November 6 to hear Remnele (a former minister in Karlsruhe) explain "What the November 15 election is all about." Even more impressive than the steady crowds which attended the SPD!s meetings were the masses of people who turned out on November 8 to hear Blerbucher (Berlin) remark about "the meaning of the Landtag election in Hessen." Two thousand strong, the eager audience applauded his comments. November 10 saw another meeting at which a crowd of five hundred people gathered to hear the Re1chstag member Schumacher (Stuttgart) and the Mayor of Darmstadt, Delp, urge the voters to support the SPD in the election. Without slacking up on the pace another meeting was held on November 12, Just three days before the election, Marie Juchacz (Berlin), also a Relchstag member, reminded the women of Pfungstadt that the SPD had won women their rights. She exclaimed that 1t was the duty of every woman to find out the facts and make non-emotional response at the polls. Five hundred and fifty men and women listened with approval to Juchacz. ${ }^{29}$ The rest of the election campalgn included the distribution of handbills, newspaper advertisements, and personal pleas from SPD members to the electorate. 
On Novenber 14 the SPD published a final appeal to the voters in the Anze1ger reemphasizing the fact that the SPD presented an orderly a.d not a radical approach to the complex difflculties of the day.

Throughout the campa1gn the KPD had la1d great emphasis on the demise of the SPD, at one point claiming that the SPD was for all practical purposes dead. The KPD, as was thelr habit, had run a smooth campaign which stressed the local members' involvement in propaganda gatherings. Huxhorn was the focus of the entire effort. His booming volce set both policy and the tone for the campaign. One of the continuing strategies of the KPD was to use the opposition's platform as the means to their own end. KPD members dutifully entered their names with the chalrman of each SPD meeting for the discussion period which traditionally followed the maln speech. At that t1me the KPD speaker, most often Huxhorn, would hammer out the KPD objections to the particular area under discussion. At the same time he would set down the KPD's alternative solution to the problem and urge the people in attendance to follow the KPD's line of thinking. Supplementing the robbery of the SPD's organization effort were weekly KPD meetings and nightly discussions in restaurants all over Pfungstadt. ${ }^{30}$ The combination of informed debaters and impressive propaganda effort supplied the KPD with a great boost. A boost which set 1 t on the 
course for the election with the feelings of winning confidence.

Included in Huxhorn'; busy scheoule was the NSDAP meeting on November 1. Over the last weeks of the election the talk among the members of the middle class had been almost exclusively of the NSDAP. Therefore, no one was too surprised to see the NSDAP meeting well attended by allarge legion of active supporters. Whereas earlier meetings had been populated almost exclusively by hostlle workers, in the last weeks of the election a growing body of Pfungstadt Inhabltants declared their preference for the Naz1 party. 31 The last two weeks of the campalgn were filled with the distribution of handbills, newspaper advertisements and private discussions among newly converted supporters (not necessarily members of the NSDAP). As one more device to insure order, all outdoor public meetings, parades and marches were cancelled after November 12 by the state police. This did not deter Adolf Hitler from making a campalgn appearance in the Festhall of Darmstait on November $13 .{ }^{32}$ He told the crowd that only real national1sm would lead to soclallsm and declared that Germany would have to change 1ts national face. The election campaign had drawn to an end--the decision would be made by the voters.

Five thousand and elghty-seven people were eligible to vote in Ffungstadt for the Landtag. Of that 
number four thousand eight hundred and forty-three cast votes--an amazing ninety-five point two percent. Dominating the political scene in Pfungstadt after those four thousand elght hundred and forty-three people had made their decision known was the National Soz1al1stische Deutsche Arbe1ter Parte1 w1th one thousand seven hundred and fifty-eight votes. Closely following the NSDAP, but second at the polls for the first time in recent memory, was the SPD with one thousand five hundred and seventy-two votes $(32.89 \%)$. Third in the balloting was the KPD with one thousand forty votes $(21.58 \%)$. Together the three partles had polled over ninety-one percent of the votes cast in the election. The battle for Pfungstadt had become strictly a three-party affalr. And since the parties which represented the most likely radical alteration of soclety had garnered fifty-elght percent of the votes, the case for democracy looked somewhat less than promising. The traditional middle class parties reached only to small percentage $(9.25 \%)$ of the voters. 33 clearly tradition among the middle class had given way to fear, to a desire for change at any price. Middle class falth in the ex1sting system of government had disappeared under a hail of NSDAP votes. The NSDAP had succeeded in capturing nearly elghty percent of the mlddle class vote. The workIng class vote (total KPD and SPD votes) actualiy Increased by elghty-nine votes, from two thousand flve hundred 
and sixty-two to two thousand six hundred and fifty-one. Thus one is falrly secure in assuming that the Nazis were confined to the ranks of the middle class while the SFD and the KPD fought a viclous duel for the trust and support of the workers. (See page 460 for a complete breakdown of the election results.) Clearly a victory of change had come at the expense of past loyalty. The Nazl machine recelved a big boost in 1931.

The KPD grew to one hundred and twenty members in the weeks after the election, whlle the KPD unemployment commission counted many new recrults also. Huxhorn was Interested in securing wider publicity for the party through the use of more regular distribution of KPD handb11ls. The party acquired a typewriter, and a small hand printing machine, which vastly increased the propaganda potential of the party. Huxhorn noted that "we had to find the smallest restaurant for our meetings in earlier years; In 1931 the largest hardly was b1g enough." 34 The results of the election emboldened the KPD to press their cause even further since the SPD had recelved only five hundred and thirty-two votes more than they had. The Assoclated Union took a mliltant attitude toward the Naz1 galns. One leader spoke for a slzable majorlty of the workers when he called for a boycott of all business whose owners had voted for the NSDAP. He remarked, "It is not necessary for the workers to take thelr money to our deadly 
enemies. "35

The most dramatic effect the Landtag election had on the political scene in Pfungstadt had to wait unt1l November 28 when the Landbund officially announced that it was politically neutral in all of Hessen. ${ }^{36}$ Polltical neutralIty did not indicate that the Landbund would cease to exist, only that it would redefine its political intentions in light of the erosion of farmer support for the political forays of the group. In Pfungstadt the group had sliped badly from the heyday of its power when it had polled upwards of five hundred and sixty votes (15.4\%) in the 1928 Relchstag election. By 1931 only one hundred and sixteen voters $(2.43 \%)$ were st1ll found backing the Landbund polit1cally. The majorlty of the farmers saw the Landbund as too weak to put the 1deas of the farming community into effect, even though they retained a fond place in their hearts for its existence. 37 Indeed, as the Landbund declared 1ts political bankruptcy, its leaders insisted that the main weapon at the disposal of the farmers was their unity under the (non-political) banner of the Landbund. Many farmers actually mourned the passing of the Landbund from the political scene, and vowed to retaln their ties to it anyway. It seems that the leadership of the Landbund saw the move as a strateglc block to the increasing power of the NSDAP within the farming community. Faced with the prospect of total annihilation, the state leaders of the 
Landbund moved to cut their political losses in order to retain a semblance of influence in other questions. Jãger, the local leader of the Landbund, operated his post in a normal manner as if the Landbund st1ll retalned 1ts pol1tical bearing, whlle the bulk of the farmers shlfted their political backing to the NSDAP. The Nazis had easily cleared another hurdle blocking thelr march to power.

The bitter pill which the depression served up to the people of Pfungstadt was not confined to one group, one class, or one institution. The town council was forced to impose a ten percent "drink" tax during December, after the council members learned that over fifty thousand marks in bills had not been pald to the town. (Th1s involved principally back rent from town-owned apartments.) Wood prices had fallen, hunting rights could not be sold for the old flgure, and more people than ever were dependent upon the town for emergency welfare rellef. ${ }^{38}$ A bright spot in the dark ciouds of fear which hung over Pfungstadt was not to be found. 1931 was a tumultuous year for Pfungstadt--the year the forces of extremism grasped for the levers of power more effectively than at any time since the depression had begun. People had lost their falth in the existing government without really knowing what should take its place. The confusing eddies of discontent and anxiety 
which had plagued $P$ fungstadt politically since $1928 / 29$ had become a huge wave which engulfed the town under a flood of contradictory charges and messages. The high ground was held, for the moment, by the SPD, whlle the NSDAP lapped at their remaining stronghold. The most signiflcant devolopment during the whole year was the replacement of the traditional middle class parties by the NSDAP. The battle for the hearts of the mlddle class was declded in 1931; It remalned to be seen if the entire town would succumb to the alluring notes of the NSDAP. 


\section{CHAPTER VIII - FOOTNOTES}

$1_{\text {PA: July 16, } 1931 .}$

${ }^{2}$ PA: July 9, 1931.

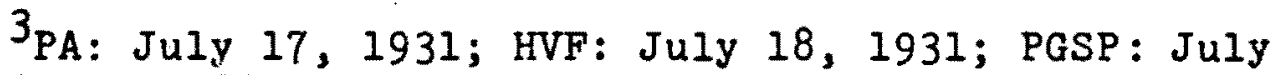
$16,1931, \mathrm{pp} .299-300$.

${ }^{4}$ PA: July 24, 1931; HVF: July 22 and 24, 1931; PGSP: July 23, 1931, po. 303-312.

5PA: July 28, 1931; HVF: July 29, 1931; PGSP: July 27, 1931, pp. 313-316.

${ }^{6}$ Rechnung über Einnahme und Ausgabe der Gemeinde Pfungstadt für 1930, 1931 and 1932, pp. 35 and 96.

7 Interviews with Jacob Hanbuch, Adam Ruckelshausen, Jacob Brauer and Wilhelm Kaffenberger.

${ }^{8} \mathrm{PA}$ : August 12, 1931 and HVF: August 12, 1931.

${ }^{9} \mathrm{PA}$ : August 1, 1931.

${ }^{10}$ Interview with Georg Herth.

${ }^{11}$ Interviews w1th August Hechler, Änne Gilbert and Peter Crößrnann.

${ }^{12}$ PA: July 9, 1931; HVF: July 12, 1931; interviews with Johann Kölsch, Adam Ruckelshausen and Karl Hechler.

${ }^{13}$ Interview with Georg Llebig.

${ }^{14} \mathrm{PA}$ : August 19, 1931 and HVF: August 18, 1931.

15 HVF: July 21, 1931.

${ }^{16}$ Interviews with W1lhelm Kaffenberger, Heinrich Schaffner and Jacob Hanbuch. 
17 PA: August 17, 1931 and HVF : August 24, 1931.

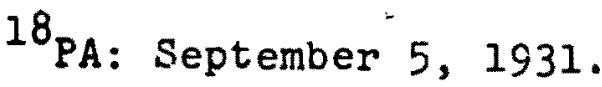

19PA: September 11, 1931 and interviews with Julius Winkler, Georg Herth, Heinrich Sand and Johann Kölsch.

${ }^{20}$ Interview with August Hechler.

$21_{\text {PA: September }} 24$ and 30, 1931 and HVF: September 1 and October 3, 1931.

22 HVF : October 14, 1931.

${ }^{23} \mathrm{PA}$ : October 18, 1931 and notes from the private. flle of Hans Otto. 1931.

${ }^{24} \mathrm{FA}$ : October 19, 1931 and HVF: October 19 and 26,

$25_{\text {HVF : October 22, } 1931 .}$

${ }^{26}$ FA: November $7,1931$.

27 PA: October 20, 22 and November 12, 1931.

${ }^{28}$ PA: November 2, 1931.

${ }^{29} \mathrm{PA}$ : November $5,9,12$ and 14,1931 and HVF: November $6,7,9,10,12$ and 14,1931 .

${ }^{30}$ Interviews with Karl Emig and Jacob Delp.

${ }^{31}$ Interviews with Julius Winkler, Maria Schulz, Adam Ruckelshausen and Helnrich Sand.

${ }^{32} \mathrm{PA}$ : November 12 and $14,1931$.

$33_{\mathrm{PA}}$ : November $16,1931$.

${ }^{34}$ Notes from the file of Helnrich Huxhorn and interviews with Georg Herth and Peter Crößmann. 
$35_{\mathrm{HVF}}$ : November 23, 1931.

${ }^{36} \mathrm{PA}$ : November $28,1931$.

37 Interviews with Ludwig Gunkel and Ludwig Wenz.

${ }^{38}$ PA: December 8, 1931; HVF: December 9, 1931; PGSP: December 7, 1931, pp. 334-335. 
CHAPTER IX

OLD MOODS, NEW METHODS - JANUARY, 1932 TO JULY, 1932

Between the June 6, 1920 Reichstag election and the November 11, 1931, Hessen Landtag election, nine hundred and forty-five citizens $(1920-4,142,1931$ - 5,087) had gained the right to vote in Pfungstadt. During that same period the number of people voting for elther the SPD or KPD had Increased by seven hundred and fifty-two (KPD 1,030, SPD - 81; the USPD went from 359 to 0 ), while the percentage of the votes all "workers" (KPD plus SPD) parties received rose from $54.09 \%$ in 1920 to $55.46 \%$ in 1931. 1 These figures clearly indicate that the working class identified their political interests in either the KPD or the SPD, not the NSDAP. At the same time the NSDAP control of the middle class vote had risen from zero in 1920 to an astonishing eighty percent in $1931 .^{2}$ In 1928 the KPD and NSDAP had control of only 15.12\% of the electorate at the polis while in 1931 the two counted $58.36 \%$ of the vote. The most significant factor to come out of the voting statistics is the fact that the burden for the preservation of republican style government had shlfted from the shoulders of the traditional middle class parties and the SPD to the SPD alone. The SPD, in 
effect, was now called upon to reverse a political situation that had been created by the middle class, while the KrJ launcled roundhouse blows at the weak underbelly of the SPD--the unemployed. During the best of times the SPD had had nothing more than a reasonable relationship with the bürgerlich; ${ }^{3}$ a SPD jump into middle class politics during the 1920's would have been met with suspicion, disbellef, and most likely ultimate fallure. At the same time a SPD move to the "right" would most certainly have left the field to the uncompromising leaders of the KPD. In the midst of the depression, the SPD had everything to lose and the bleak prospect of substantial gain, if they had attempted to shift middle class support away from the NSDAP. The KPD would, without doubt, have been the recipients of a rich, new vein of working class support. The SPD would have been left with nearly nothing but the hardest core of its supporters. Thus the SPD cautiously experimented with a more radical stance during the flist half of 1932. The Hessischer Volksfreund announced the shift to the SPD members in an article entitled, "The evening of the capitalist 1dol;" in first days of January. 4 close on the heels of the articie was a SPD meeting at which the political development of Germany between 1918 and 1932 was discussed vigorously. Zinnkann (Darmstadt) flrst traced the changes whlch had occurred for the audience, then threw the meeting open to comment. 5 
Later in the month Stock (reglonal chalrman of the Relchsbanner) put the question to the workers more bluntly in his. speech, "Red Unity Front or Iron Front." He declarcd that the working class had to prepare itseif for a defense of the Republic or face destruction. He announced plans for the formation of an "Iron Front" (composed of SPD, the Assoclated Union and SPD club members) to take the wind from the salls of the ant1-democratic forces in Hessen through a display of the solidarity and strength of the working class. The first meeting of the Iron Front in Pfungstadt was to be February $3 .^{6}$

Like a thunderbolt the SPD was deprived of its outstanding symbol of accomplishment and fortitude at midnight on February 2--Georg Raab died. As the Anzelger reported in its February 3 edition, "Johann Georg Raab, popular and highly respected by everyone in the surroundIng area, was a friend of the people and a real man." The Volksfreund called hIm a "Son of the people," and devoted full-page accounts of his death, his accomplishments and his funeral in separate issues. ${ }^{7}$ Ministerpresident Adelung along with a host of official and unofficial representatives came to pfungstadt on the third to pay their respects to his widow. Over three thousand Reichsbanner members alone marched with the Raabs's coffin from his home on the Eberstäderstraße to the cemetery where just about every important political figure 
In Hessen and a sizable number from all over Germany assembled to hear the last words spoken before his coffin was covered with a tradiciona: shovel full of dirt by each of the mourners. Georg Raab's totally unexpected death left a deep Impression upon the hearts of many of Pfungstadt's cltizens, but particularly the SPD. All of the SPD sponsored and SPD associated clubs assembled on Friday evening, February 5, to honor Raab's memory. The widest range of political adherents consldered Raab the good man that he was. An NSDAP member simply sald, "He was a fine man." The daughter of a middle class businessman went even further, saying, "He was loved." 8 In the minds of many people Raab represented not only the SPD, but also the town of Pfungstadt, a qualification which stripped away most of the resentment for his life-long work for the soclalist movement.

The inner circle of SPD leaders was depreived of a valuable volce of reason and good advice with the untimely death of Raab, but it was not crippled. If it was possible, Raab became more of a symbol for the SPD after his death than he had been when he was alive. The Iron Front meeting which was scheduled for February 3 , the very day Raab's death was announced, was held as planned. But a slight revision in Landtag member Maurer's (Lauterbach) proposed speech concerning Hessen politics and the Iron Front took place. After his remarks were concluded, the 
leader of the Iron Front in Pfungstadt, Albert Wälke (he was also the chalrman of the Relchsbanner) proclaimed that the fight against facism wuld go on as Georg Raab would have desired. 9 The KPD, wh1le deeply consclous of Raab's value to the workers, thought differently. A KPD representative branded the entire Iron Front a device to Insure the reelection of Hindenburg to the presidency of the Republic. He called on the workers to repudiate the policies of Hindenburg and his associates by voting for Thälmann, the leader of the German KPD. The SPD party was itself rather hard put to fight the facist threat because of a delicate financial situation within the local party. The SPD's treasurer had reported in a January meeting that not much money was left to campaign with. He suggested that the party stop its payments to the Land organization of the party in order to concentrate all of the local party's money on the upcoming presidental election. 10

Money aside, the Iron Front actively pushed forward with their attacks on the NSDAP. At February 24 and February 27 meetings the Iron Front appealed to all republicans to attend to the business of preserving the Republic. The response was gratifying. Over six hundred people attended each of the sessions. The overriding theme of the first meeting was put forward by the Landtag member Ludwig Rink, who said, "The class of capital agalnst the working class, that is the situation today in Germany. Two things 
are particularly 1mportant for that struggle: 1) the disunity of the workers, and 2) that Hitler is using the tarrible aconomic situation to influence people who have never done a thing as long as they had more than enough to eat." Other speakers attacked the war record of the Nazis, pointing out that, "In reality the people who today spread Nazi propaganda did not even take part in the war. Statistics prove that elghty percent of the SPD Relchstag rep.resentatives are veterans of the war while only thirty-seven percent of the NSDAP Reichstag members fought at all."1l Th1s strong defense of the SPD war record was strangely set against the Iron Front's promotion of the film "All Quiet on the Western Front" which was being shown in Pfungstadt at the time. ${ }^{12}$ If the SPD was trying to impress the middle class, they still had some way to go. If on the other hand they were endeavoring to balance KPD initiatives in the fleld of anti-war sentiment they would have had to assume a more militant attitude. They were again caught in the middle, between a middle class which wanted to believe the worst about the $S P D$, and a KPD which sald the worst about the SPD. Rink struck a cord which promised more response when he ended his speech by saying, "In good times it is easy to be a Social Democrate. In these hard times every man and worran from the working class must help to put the nobles of industry out of business in order to insure the well-belng of [we] workers and [our] chilaren." The SPD 
remained ensnarled in defending itself against middle class assaults. The KPD boldly avolded such situations by simply rejecting all those things which the middle class stood for.

The Reich presidental election supplied the KPD with a great deal of valuable ammunition for their campaign. The SPD promoted the election of Hindenburg with the slogan: "Vote for Hindenburg, the last bollwork against facism." The KPD gleefully reminded their SPD opponents that in the 1925 Reich presidental election the SPD had campalgned with a different motto. In 1932, the leadership of the KPD procla1med, the SPD's 1925 max1m: "Whoever votes for Hindenburg is voting for the reaction and is an enemy of progress," was still valid. 13 Such remarks made the SPD's efforts harder than ever and influenced a number of people who were wavering in their loyality to the SPD to reexamine their views. Another KPD stand which brought the party supporters was the KPD's uncompromising pledge to oppose facism with force. In January forty KPD members had held "manouvers" in the town's forest. 14 The state police eventually arrested one man for the incident. Such KPD actions gave birth to the wildest rumors: one had the KPD stockpling a huge assortment of weapons somewhere in the forest, while another had the KPD actively planning to take over Pfungstadt by infiltrating armed men into the town at night. 15 The sheer size and influence of the KPD 
in 1932 plus the rumors and gossip of bürgerlich citizens drove a large section of the middle class to see the electoral struggle for Pfungstadt exclusively in Communist versus Nazi terms. Other signs staunch respectable middle class people took as bespeaklng the introduction of anarchy were the frequent thefts of potatoes and meat from farmers and butchers. 16 The police did what they could to control such activities, but many unemployed fathers were ready to risk a jail term if it meant that their families would be fed. It was no Nazi trick which prevoked the bürgerlich to stream into the electoral ranks of the NSDAP, but a stubborn blindness on the part of the middle class. The depression and the dramatic growth of the KPD drove many middle class cltizens to seek out a "new" party. As one middle class citizens said, "If the Nazis do not solve our problems then we will vote in another party that w1ll." 17 Such utterly naive thoughts proved a hard target for the SPD or any party to destroy.

Despite dally attacks by the Volksfreund on the NSDAP the Nazis enhanced their overall numbers significant1y. From a small group of ten or twelve men in 1931 the SA had grown to over fifty. ${ }^{18}$ Part of the growth is directly attributable to the secret contribution of modest sums of inoney from many of the most esteemed members of the community. A well-known businessman, who feared the working class reaction to an overt endorsement of the 
NSDAP, often bought enough uniforms to outfit several SA men. 19 Indeed, the bürgerlich had long since stopped arguing the merits of the NSDAP. They wanted change and they wanted it soon, they were ready, willing and to a large degree able to prop up any group which could effectively bring about a revision of the depressing fiscal and political situation. Keying on this mood, the NSDAP deliberately set out on February 14 to promote Hitler's cause In the presidental election of March 14. Landtag and Relchstag member Lenz, the main speaker, recited the standard list of party goals before a large crowd. He contented that the NSDAP was acquiring ever more adherents because of 1ts real concern for all of the people. Partnership, he vowed, partnership between men of every station and every religion was the goal of the NSDAP. 20 The NSDAP promotion of community "partnership" received another indirect boost when the local Ortsgruppe published an analys1s of the "Marxist" basis of class struggle in the Anzelger. Desplte the transfusion of more moderate middle class leaders into the NSDAP after 1930, a hard core of "soclalist" members remained imbedded in several party posts. This assured that the "old fighters" would strongly attack the KPD and the SPD at every opportunity. The analysis of the class struggle by Lenz was just such an assult. Under the title "Party News," the Nazi writer stated that, "The Marxists continue to spread the idea of class struggle 
among the working class. The disunity of the workers is the direct result of the idea of a class struggle. The SPD is a dying political party because the membership is finally seelng through the lies of the working class 'leadership'."21 The concept of uniformly labeling the leaders of the working class as "marxists" and thus excusing the actions of the workers themselves gained a few more adherants with idealistic outlooks to the NSDAP.

Yet another front was opened in the full fledged war for power which was raging in Pfungstadt in 1932 when the NSDAP made known the founding of a Frauenschaft (womens club) on February 26.22 The flrst meeting of the Frauenschaft heard Getrud KIInk discuss, "Women In the National Sociallst State." Her words accented the 1mportance of women in the reconstruction of Germeny--not poIItically but in their homes as mothers and helpmates. An Inauspiclous number of onlookers showed up for the meeting. Throughout 1932 the great majority of Pfungstadt's women were leery of the group, much as the men had shyed away from the $S A$, and probably for many of the same reasons. 23 Rounding out the list of prospective supporters who the NSDAP tried to move into their camp were the farmers. Just two days before the election the NSDAP delivered a "Statement for the young farmers" at a special meet1ng. 24 The NSDAP's chances were Improved even more after the Landbund announced that it would not endorse any can- 
didate. 25 The NSDAP campaign for H1tler's presidental aspirations in 1932 was far removed from the poorly organized al.d miserably run campalgns of 1928 and 1929. 1930 had been the turning point, 1931 the maturing period, while 1932 revealed a well financed, well organized and extremely conflcient party. The party had gained momentum and poise. The old splinter party Image was dead, a near majority party had emerged.

In the SPD wrestling match with the NSDAP ridicule was one of the main weapons in the SPD's arsenal. On March 11 the Volksfreund chlded the "heroes of the Third Relch" for their blunder in accusing Peter Crößmann of assulting a NSDAF leader in Eberstadt. The charge was so ludicrous that the pollce took only a few hours to clear up the matter. The Volksfreund was even happler to report that the police had searched some NSDAP houses in Pfungstadt with the result that they found a rifle just two days before the election. ${ }^{26}$ on the lighter side the Volksfreund laughed along with its readers when it informed them that someone had painted "Vote Thälmann" (KPD) on the side of the Cathollc priest's car as he sald mass in Pfungstadt. Unfortunately the campaign had seen too little humor and too much grating propaganda. As in other elections the hotter heads among each party sought each other out in the streets as each party pasted posters to walls or tore down the posters of 1ts opponents. The Anzelger displayed 1ts 
usual unpolitical head when 1 t banned all party news and letters to the editor from its March 11 and 12 editions. 27 A prudent move in a town burning with inflamatory rhetoric. People did not get along with each other any more.

The results of the election in Pfungstadt confirmed the strength of the NSDAP and the KPD. Between themselves they polled fifty-elght percent of the vote. The exact returns were:

RESULTS OF THE MARCH 13, 1932 REICH PRESIDENTAL ELECTION 28

$\begin{array}{lrr}\text { Hindenburg } & 1,931 & 41.10 \% \\ \text { H1tler } & 1,722 & 36.65 \% \\ \text { Thälmann } & 1,001 & 21.31 \% \\ \text { Dusterberg (DNVP) } & 27 & 0.57 \% \\ \text { Winter (Wirtschaftspt.) } & 16 & 0.34 \%\end{array}$

Conflrming the power of the NSDAP and the KPD was one thing, confirming the continued expansion of the NSDAP and KPD vote was yet another. Nelther party achleved their 1931 Landtag totals. Although a small dent had been made, no promise of a political reversal could be percelved from the vote. And nationaliy as was the case locally, no candidate had recelved the manditory fifty percent of the vote. Another election would have to take place. The date flxed for the election was Apr11 10. A combination of the depletion of party funds, lack of time and an energency ban on all political meetings in the state of Hesse-Darmstadt led to a minimum of public meetings be- 
fore the second election.

The NSDAP bided 1ts time along with the other contunding groups until the ban on meetings explred on April 3. In an impressive display of timing and organization the NSDAP scheduled 1ts first public meeting of the second presidental campalgn for four o'clock in the afternoon of Saturday, Apr1l 3, barely four hours after the meeting ban ran out. ${ }^{29}$ District propaganda chief Trefz beat away at the theme, "Germany's frightful struggle," suggesting that only the Naz1s could lead Germany out of the chaos which surrounded everyone. Th1s speach brought 1nto a clearer light the second bugaboo of Naz1 propaganda--chaos. The double fear of "marxism" and chaos were to recelve more attention in the coming months.

The campalgn of the Nazis was counterbalanced by the activity of the Iron Front. On April 6 the Relchstagimember RItzel discussed, "Why Hessen should vote for Hindenburg" before a large audlence. Well recelved because of his humor and speaking ability, Kitzel defended the SPD supporting Hindenburg in the election. 30 Hindenburg's chances in Pfungstadt recelved another boost when a Committee for Hindenburg Jumped into the campalgn. The purpose of the committee was to garner middle class support from the Naz1s. The pronouncements of the group were almed at arousing a fear of change amorig the bürgerlich. A newspaper campalgn included the provocative question, 
"Should: our people, our homes and our families, the basis of our existance, be handed over to experimental radical1sm? The German ship of state is negotiating a heavy sea, don't change captains. Don't change from the captain who knows every reef and shoal. Vote for Fleld Marshall von Hindenburg." 31

Although the state of Hesse-Darmstadt gave Hindenburg a majority of the votes (53.15\%), Hindenburg's percentage In Pfungstadt increased to only $44.00 \%$. The exact figures were:

RESULTS OF THE APRIL 10, 1932 REICH PRESIDENTAL ELECTION 32

$$
\begin{aligned}
& \text { Hindenburg - 2,044 (1931)* - 44.00\% (41.10\%) } \\
& \text { Hitler }-1,840 \text { (1722) - } 39.61 \% \text { (36.65\%) } \\
& \text { Thälmann - } 761 \text { (1001) -- 16.38\% (21.31\%) }
\end{aligned}
$$

Fifty-three fewer voters went to the polls (March-- 4764, 93.05\%; April - 4711, 91.78\%), but that was not the most important news of the election. The startilng drop in KPD voting strength ranked number one, while the growth of NSDAP support was a close second. The SPD conceeded that the KPD had staged a hard campaign, marching through the streets of Pfungstadt the day of the vote, but suggested In the Volksfreund that the unemotional, but tenacious efforts of the SPD had revived its sincere image among the working class voters. 33 The SPD's analysis is partially

* March 11, 1932 election returns. 
correct, but they forgot that they were not winning new voting support, merely rewinning former adherants, and without the promise that they would remain in the SPD fold for long. The NSDAP had climbed up another couple of percentage points. That they could gain those votes in the face of the number one symbol of traditional order, Hindenburg, indicated that they could expect to hold the newly won electoral supporters in future elections. The bürger$11 \mathrm{ch}$ were in the throes of finding new faces to solve the depression. Because of thelr search even their old loyalty to the Fleld Marshall could not hold them to the Republic.

The delfberations of the town counc1l were not overlooked by the Inhabltants of Pfungstadt in the shuffle of Relch politics. Several emergency measures had gone Into effect early 1.] January, Including another cut in officials' pay and various rent and price changes. 34 The town counc1l members had to deal w1th these developments and their own fiscal difflculties. Besides taking cognizance of firty thousand marks of payments due the town, the counc1l approved a longer repayment period for a 1927 state bullding loan at 1ts January 4 session. 35 In March the council cut money for the construction of a c1ty park over the objection of the KPD which claimed that the counc1l was taking jobs away from the unemployed. 36 Apr11 produced the conclusion of a flght over the school. Increased student attendance dictated that two additional 
teachers be engaged in the schools, but the money for the project could not be expended according to Martin. In addition the councll had to lay aside pians for adcitional town housing at the insistance of the bürgerlich. The oppressive opposition of the middle class to all money measures hindered the council from approving jobs for the unemployed replanting trees in the forest and the approval of only elght hundred marks for twenty-nine familles with large nembers of chlldren whose heads had been long unemployed. 37 The final councll meeting in the first half of 1.932 resolved to provide some spot employment for the chronically unemployed by alloting enough funds for the construction of a wall around the cemetary. The bürgerlich members of the council found support for their constant objections in financlal matters in the audit of the 1930/31 budget. ${ }^{38}$ The report stated in part:

The total cost of town emergency unemployment payments amounted to RM 158,766.26. The county supplied RM 6,798 for the Winterhilfe during 1930/31, so that the town had to allot RM I51,968.26. These figures establish the financial alamity of pfungstadt in 1930, a situation which is unbearable for the community. The Kreisamt as well as the Ministerium were constantly informed of the catastrophic financlal plight. In the $1930 / 32$ budget year subsldies from the Relchshilfe and loans from the Hessen Compensation Fund were transfered to the town account, however not in sufficlent quantity to allow the town to meet 1 ts financlal responsibilities.

While national polltical machinations attracked their share of the headlines, the gut political fight for the 
fiscal control of Pfungstadt sturred the emotions of Pfungstadt's inhabltants as much as ever.

The Volksbank proudly annourced that it retained sufficent funds to remain liquid on April 9, but had to conceed that its deposits had dropped in the past year. 39 As the public and private stock of financlal resources sank, the tempers of both the right and leftwing parties grew shorter. The KPD was quick to pump the frustrations of the uenmployed to a fever pitch. On March 26 the KPD distributed a leaflet which accused Mayor Schwinn of deliberately withholding funds from the unemployed. 40 ChargIng that cash was avallable for immediate distribution to the enemployed, but that the mayor had prohibited 1ts distribution, the KPD wrote, "Immediate action is called for, demand your rights!" General notice of Mayor Schwinn's vehement denunclation of the charges had an immediate impact on the town's citizens since Mayor Schwinn was highly respected in every class and circle of the populace. But the damage was already done. The unemployed were very discontented with their situation, ready to grasp at the thinest promise thrown their way. The leaflet only added more fuel to the already biazing resentment among the unemployed. On the other side of the fence was the Kommunale Wähler Verelnigung wh1ch encouraged distrust of the town's administration too. On April 23 the Vereinigung staged a 
display of temper over the reevalutation of property values whlch the town administration had undertaken over a three week perlod. Martin charged that many of the newesi evaluations of the officlals were unrealistic and inflated. Other areas whlch were under susplction were the taxes on profits and captial. Martin also summerized the work of the counc1l for the large audience of interested onlookers. One speaker after another warned the assembled throng to become informed about the tax situation in Pfungstadt and how they would be hurt. Near the end of the gathering, a Kommunale Wähler Vereinlgung spokesman promised the crowd that his group would try to improve the business prospects in Pfungstadt. As the final paint of business, the group decided to alter its name. In the future the group would be called the Kommunale Verelnigung Pfungstadt. ${ }^{41}$ Under the spell cast by the depression the KPd and the Verelnigung strove for different goals along simflar paths. Their concerns were neither mad nor insane, but the exaggerated reaction to a crazy depression which no one understood.

The SPD counteracted as best it could, w1th the most proven methods at its disposal. The May Day celebration was just such a method. Neutralizing the KPD's lunge forward was the primary concern of the SPD and the Associated Union, therefore they promoted the celebration with a ferver. 42 Notwithstanding financial difficulties which dic- 
tated a more conservative outlay of funds for decorations, the event proceeded smoothly. Together with a speech by Stampe (Frankfurt) the Ass jciated Union sponsored a picnic for a large representative crowd. ${ }^{43}$ Attacklng with great vigor, the SAJ, as they had during the Landtag and Reich presidential elections when they satirized opposition candidates through marvelous little mini-plays, called for "soclalist partnership" on May 8. Employing the theme, "We never want to carry the weapons [of war] again," the group drew a large number of working class youngsters (and the1r parents) to the SAJ He1m. Peter CröBmann enunclated his feelings toward war on a program which included folk dances and songs. 44 Another demonstration of SPD unity and ongoing strength was the party gathering on May 21. Delp (Darmstadt) spoke of the political situation throughout Germany and the state of the Landtag in Hesse-Darmstadt. At the same time August Hechler and Peter CröBmann were elected to represent Pfungstadt at the oounty level party assembly. ${ }^{45}$ In addition to the normal business of day to day party matters, the leaders of the SPD had to begin to map thelr strategy for the upcoming (June 19) Landtag election. The opening shots of the campaign were fired by the Iron Front at a meeting on June 9. Calling

\footnotetext{
*The November 15, 1931 Landtag election had been declared Invalid by the Hessen State Supreme Court.
} 
upon the services of the exiled Italian socialist Victor Mungioll to detail, "What the working class can expect from facism," the party launched a strong headon attack on the NSDAP. Cueing on the assumption that Italian facism and German nazism were intertwined philosophies, Mung1011 reclted a long list of abuses and suppressive actions which the SPD could expect if the NSDAP came to power. ${ }^{46} \mathrm{~A}$ larger demonstration of SPD power was planned for June 14 on the square in front of the town hall. Titled a demonstration for freedom and work, the gathering was proceeded by a march through the streets by Assoclated Union members, club members and Re1chsbanner assoclates. The participants marched from the train station along the Eberstädterstraße to the town hall where the Relchstag members Saupe and Maria Zammert addressed them. 47 The SPD managed to take the offensive with these two meetings by stressing the dread of Nazism at every turn. The newly uncovered "Boxheimer Documents" lent the statements of the SPD even more credance in the eyes of thelr followers. The KPD also recelved its share of the blame for the Nazls growth. The KPD was accused of beling narrow minded in both outlook and action. Closing each meeting were the challanging words, "If your freedom is worth something, if you love your country, if you don't want your children to become cannon fodder, then put an end to H1tler's movement, vote for the SPD on June 19!" As the final speaker in an impressive 
list of national figures who visited Pfungstadt during the election campalgn the SPD mustered Relchstag member Carlo Mierendorff to the front. Mierendorff came directly to the point in his remarks at the last public SPD meeting before the election, demanding that the voters "Make Hessen free from the swastika." The last SPD gesture before the election involved the young members of the party who braved the dangers of physical confrontation to distribute handbills the day before the election. 48

The activities of the KPD were many and varied, although public meetings did not assume the same importance as they did for other parties. KPD men used the opponent's meeting for a forum; airing communist propaganda was a favorite tactic. Another pasttime, practiced with considerable skill, was the destruction of the oppositions' posted handbills and confrontations with people who attempted to spread the word of an opponent in working class restaurants and meeting points. A June 9 public meeting played a part in Huxhorn's strategy, but by and large the party relied on individial contact between prospective voters and convinced followers to bulld a strong foundation of support for the vote. 49

A cloud of suspicion, as vieved with anti-Nazi eyes, was cast over the NSDAP when the Interior minister announced that a large amount of materlal concerning $S A$ and SS intentions together with weapons were found in a state- 
wide search of Nazi homes. Paralleling the state governments discoveries was similar action in Hahn (three kilometres south of Pfungstadt; which produced equivalent results. 50 The thought that the Naz1 party, despite evidence which would seem to irrefutable substantiate the charge, would institue a dictatorship after assuming power efther legally or by revolution did not penetrate the minds of the midile class. The bürgerlich rejected the SPD/KPD arguments in part because they firmly believed that the SPD/KPD were just as responsible for the confrontation atmosphere in Pfungstadt as the Nazis. Then there were the words of Ortsgruppenle1ter Gräff himself. He stated quite unequivocally that the NSDAP would most 11 kely have to establish a dictatorship after 1t assumed power, but only long enough to restore both fiscal and political order. 51 The parties of the WeImar Republic had failed, he argued, to provide a remedy to the depression, the Nazis would supply the cure, even if it meant stepping on the toes of the SPD and the KPD "bosses." The NSDAP was not afraid of exploring new means of spreading Naz1 propaganda while a ban on party meetings existed in Hessen. On May 28 the NSDAP presented a "concert" in the restaurant "Goldenen Lamm." Between musical presentation Abt (Darmstadt) presented his Ideas concerning "Theory and Reallty," which Included a strong attack on the SPD for not belng able to realize the difference between the two. In addition to his uncompli- 
mentory remarks about the SPD, he dwelt with the positive aspects of the NSDAP. He promised a new state with bread and work for every German. ${ }^{52}$ After the ban in Hesse-Darmstadt on demonstration, marches, meetings, and the display of party flags was raised by Leuschner, the Naz1s staged one of their most ambitious efforts to find new supporters. On June 8 Minister Knab* (Gustavsburg) spoke in the overflowing "Goldenen Lamm" about "Christianity, Communism and National Soclalism." In a stinging denouncement of communism and the "Moscowers," he implored the audience to reject lazy, immoral marxism and think "German" once again, so that they might serve God and country. His remarks were not universally accepted. A disenchanted spectator, provoised by his comments, threw a rock (or bottle) at him during his speech. In addition to Knab, a man named Kraft Inflamed the audience with disparaging remarks about reparations, promising that when the NSDAP got into power the: money would not go abroad, but would be used to put one mililon people to work. Fired by the speeches several members of the audlence endeavored to convince opponents of the righteousness of their respective positions in a brief scuffle after the meeting. 53 with one week left in the campalgn, the NSDAP showed no signs of letting up. On June

\footnotetext{
* Minister Knab had been a deacon in Pfungstadt between 1923 and 1924 before being transfered to Gustavsburg.
} 
14 the party held a meeting in the nearby village of Hahn, but spared no expense because of the small number of villagers. The retired Protestant minister Münchmeyer spoke to the gathering which included a healthy sprinkling of people from Pfungstadt. On Thursday, June 16, the party concluded its campaigning with a gathering aimed at attracting more women to the polls. 54

The most interesting development in the campalgn involved a party which did not even have a single candidate speaking for it at a single rally. On June 18 the Kommunale Vereinlgung Pfungstadt placed an advertisement in the Anzelger wh1ch stated:

MEN AND WOMEN OF PFUNGSTADT! Do your part tommorrow to end the Marxist mismanagement of the economy which has brought us all this suffering and unbelievable poiltical terror as practised by the 'champlons of freedom' in Pfungstadt. DO NOT VOTE FOR THE SOCIAL DEMOCRATS OR THE COMMUNISTS or else things will never get better!! 58

Stelnmetz and Martin, the leaders of the Verelnigung knew very well that the warning to vote against the SPD and KPD was an endorsement of the NSDAP since the old middle class parties had staged no campalgn at all throughout the weeks before the election. Conditions had become so bad for them that the Deutsche Volksparte1, Deutsche Staatsparte1, Christlich-soziale Volksdienst, Volksrechtspartel and the Wirtschaftepartel had formed a National Unity List. The publisher of the Anzelger, Jullus Helene and the editor of the paper, Gottfried Helene, unwlling to see their 
paper mixed up in the increasingly bitter political strife banned all articles and letters to the editor submltted by political parties. The ban began on Wednesday, June 15, and lasted unt1l the election campalgn concluded on June 19. Besides fearling that poiltical invective from one or the other parties would damage thelr paper's strict policy of political neutrality, they also were terribly afraid that one of the parties would found 1ts own party paper and cut 1nto the circulation of the Anzelger. ${ }^{56}$ Electioneering was a dangerous enterprise in 1932.

Over ninety percent of the eligible voters made the1r way to the polls on June 19. More than at any other time they placed themselves in the hands of the NSDAP. Outside of the Naz1 gains no other party increased 1ts electoral support. The results were:

RESULTS OF THE JUNE 19, 1932 HESSEN LANDTAG ELECTION

$\begin{array}{lrrrr}\text { SPD } & 1488 & (1572) & 32.45 \% & (32.89 \%) \\ \text { KPD } & 917 & (1040) & 19.99 \% & (21.58 \%) \\ \text { NSDAP } & 1947 & (1758) & 42.46 \% & (36.78 \%) \\ \begin{array}{l}\text { Nat1onal } \\ \text { Un1ty L1st }\end{array} & 80 & (162) & 1.74 \% & (3.39 \%) \\ \text { Others } & 154 & (248) & 3.35 \% & (5.32 \%)\end{array}$

A marked drop in the number of voters going to the polls resulted in only $90.17 \%$ participation in the election. of

* Returns from the November 15, 1931 Landtag election. 
the 5,156 people eligible to vote, only 4,4649 used their right to decide on their representatives. In the November 15,1931 election 5,087 had been eligible to vote and 4,843 had marked a ballot. Thus two hundred and ninetyfour fewer people had taken the time to vote. The total vote of the SPD and the KPD fell by a combined two hundred and twenty-six (from 2,651 to 2,425). Thus the working class portion of the vote fell from $55.46 \%$ in 1931 to 52.88\%. The overall drop in voter participation in the election most likely accounts for the major portion of the SPD/KPD vote drop, although a few working class votes must have migrated into the Nazi column.

So much animosity, so much political hatred, so much despalr, so much despiration... as one butcher sa1d, "People did not want to get along with each other any more. "58 The hate, the fear, the lack of hope and the desperation drove men to see riches were there were none, hope where there was only a trap, order where there was only dictatorship. The first six months of 1932 had intensified what had become an untenable situation, a solution was only seven months away. 


\section{CHAPTER IX - FOOTNOTES}

${ }^{1}$ PA: June 7,1920 and November 12, 1931.

$2_{2,200}$ votes were wast by middle class citizens, $1,758(79.9 \%)$ went to the NSDAP. Even if one allows up to two hundred votes for the NSDAP to come from people who considered themselves workers, not middle class, the Nazis still captured well over seventy percent $(70.8 \%)$ of the bürgerlich. There does not seem to be grounds for assuming that even that many working class votes went to the NSDAP.

$3^{3}$ Interviews with Johann Kölsch, Jülius Winkler and Marla Schulz.

${ }^{4}$ HVF : January 2, 1932.

${ }^{5}$ HVF : January 11, 1932. 1932.

${ }^{6}$ PA: January 20, 1932 and HVF: January 23 and 25,

7 PA: February 3 and 4,1932 and HVF: February $3,4$. and 6,1932 .

${ }^{8}$ Interviews with W1lhelm Kaffenberger and Maria Schulz. 1932.

${ }^{9}$ PA: February 3, 1932 and HVF: February 2 and 9,

10 $\mathrm{HVF}$ : January 11, 1932.

${ }^{11}$ PA: February 24 and 27, 1932 and HVF: February 25, 1932.

${ }^{12}$ PA: February 24, 1932.

${ }^{13}$ Notes from the private file of Heinrich Huxhorn. In another place in his notes he mentions the fact that the KPD had backed the Nazi attempt to have the Erussian Landtag dissolved. After World War II he told Peter 
Cropmann that the KPD had acted more with emotion than with sense with regard to dissolving the Pfurrian Landtag, but that he still fully approved of the KPD having run Thaimann against von Hindenburg. Cropmann reported that he could not make Huxhorn understand the devisive effect the KPD action had had on the working class.

$$
{ }^{14} \mathrm{PA} \text { : January 21, } 1932 .
$$

${ }^{15}$ Interviews with Heinrich Schafiner, Jacob Hanbuch, Jacob Brauer, Julius Hofmann, Heinrich Sand, Luise Steinmetz and Gottfried Helene. Incidents such as this spurred the middle class to take a more militant attitude toward the working class of Pfungstadt than would normally have been the case.

\section{${ }^{16}$ HVF: February 4, 1932.}

17 Interview with Ludwig Wenz. The KPD also boasted that they would attain power after the NSDAP had falled to produce the results which they had promised to the people for so long.

\section{${ }^{18}$ Interview with Helnrich Schaffner.}

${ }^{19}$ Interviews with Heinrich Schaffner, Heinrich Sand, Wtihelm Kaffenberger and Karl Hechler. KPD and SPD people claimed after World War II to have known that such things had taken place, but this seems to be looking at the past with the knowledge of the present, not reflective of the facts in the years before 1933. If they had known they surely would have begun a boycott of the offending firms involved.

${ }^{20}$ PA: February 13 and 15, 1932.

${ }^{21}$ PA: March 5, 1932.

${ }^{22}$ PA: February 26, 1932.

${ }^{23}$ Interviews with Heinrich Sand, Maria Schultz and Ria Hanbuch.

${ }^{24} \mathrm{HVF}:$ March 11 and 12, 1932. 
${ }^{25}$ PA : March 5, 1932.

26 HVF : March 11, 1932.

${ }^{27} \mathrm{PA}$ : March 10, 1932.

${ }^{28}$ PA: March 14, 1932.

${ }^{29}$ PA: April 2, 1932.

30 PA: Apr11 6, 1932 and HVF: April 7, 1932.

${ }^{31}$ PA: Apr11 8, 1932.

32 PA: Apr11 11, 1.932.

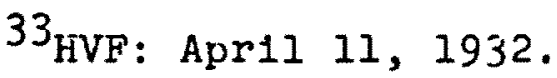

${ }^{34} \mathrm{PA}$ : January 4, 1932.

${ }^{35}$ PA: January 5, 1932; HVF: January 6, 1932; PGSP: January 4, 1932, pp. 338-340.

${ }^{36} \mathrm{PA}:$ March 22, 1932 and PGSP: March 21, 1932, pp. 355-359.

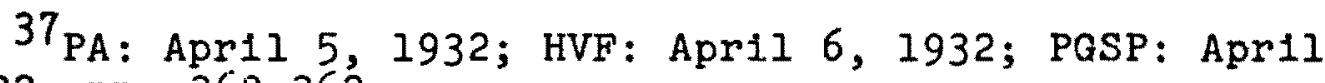
4, 1932, pp. 360-362. 367.

${ }^{38}$ PA: June 20,1932 and PGSP: June 9, 1932, pp. 365-

${ }^{39} \mathrm{PA}:$ Apri1 9, 1932.

$40 \mathrm{PA}$ : March 26, 1932 and HVF: March 29 and 30, 1932.

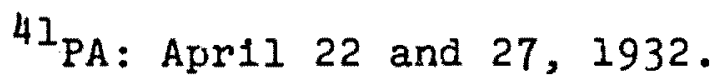

42 Interviews with August Hechler, Peter Cropmann and Georg Llebig. 
43 HVF: April 30 and May $3,1932$.

${ }^{44} \mathrm{PA}$ : May 7, 1932 and HiVF: May 12, 1932.

45 PA: May 24, 1932 and HVF: May 23. and 25, 1932.

${ }^{46} \mathrm{PA}$ : June 8, 1932 and HVF: June 7 and 9, 1932.

47PA: June 13, 1932 and HVF: June 13, 1932.

${ }^{48}$ PA: June 16, 1932 and HVF: June 16 and 17, 1932.

${ }^{49} \mathrm{PA}$ : June 9, 1932 and interviews with Jacob Delp, Georg Herth, Karl Emig and Georg Llebig. Few confrontatlons took place between KPD and SPD members over handbills and leaflets, but the animosity caused by campaigning caused tempers on both sides to grew short.

${ }^{50} \mathrm{PA}$ : April 15, 16 and 19, 1932.

${ }^{51}$ Interviews with Julius Winkler, Helnrich Sand and Jacob Hanbuch. In addition to fighting a losing cause if the SPD had attempted to make inroads into the middle class voting strength the SPD would have had to overcome the seemingly lliogical thoughts of the bürgerlich. The SPD and the KFD had clearly stated on more than one occassion that the NSDAP was intent on setting up a dictatorship. The middle class blandly cast the warnings aslde, deeming them the ravings of people who saw only the worst in an attempt to make a political gain. Indeed 1t must have seemed very remote to the middle class that the Nazis of Pfungstadt would ever be able to Impose their will over the entire town. Trying to convince a group who did not want to believe was an impossible task in the highly charged atmosphere.

${ }^{52}$ PA: May 30, 1932.

${ }^{53} \mathrm{PA}$ : June 7 and $11,1932$.

54 PA: June 14 and 15, 1932 and notes from the fille of Hans Otto.

${ }^{55} \mathrm{PA}:$ June $18,1932$. 
${ }^{56}$ PA: June 14, 1932 and interview with Gottfrled
Helene.

57 PA: June $20,1932$.

${ }^{58}$ Interview with Fitz Feldmann. 
CHAPTER $\mathrm{X}$

SEARCHING FOR A SOLUTION - JULY, 1932 TO JANUARY, 1933

Unable to come to grips with the complexities of the depression, a near majority of Pfungstadt's citizens had turned to the NSDAP to supply them with a solution. The changes wrought by the Nazis took form at the ballot box with a strong showing for the "Hitler movement." In addition to winning the single largest block of votes in Pfungstadt, the party had grown in numbers and wealth to the point where a serious question lay in the minds of the SPD as to whether the Nazis would use that power to attempt an armed revolution. The SPD had responded to the increasingly severe pressures upon them to take some action by forming the Iron Front, supposedly a coalition equal to the task of defending the Weimar Republic from Nazi threats. But over the months the Nazi threat failed to materialize; instead more and more highly respectable middle class citizens spoke in approving, if still hushed, tones of the NSDAP to restore the world to its predepression state. ${ }^{1}$ Restoring the middle class world to 
its former balance was undoubtedly the main factor which drove so many intelligent people to cast their lot with the NSDAP. There was no traditional association for the middle class with Nazism. Many citizens undoubtedly voted for the NSDAP with the idea that a shift to another party would be possible if the Nazis failed to produce their vaunted restoration of the German economy. 2 The utter lack of political education was one of the great failings of Pfungstadt's burgerlich citizens during the days of drama before 1933. While the KPD leadership analyzed every development against a supposedly infallible master plan and the SPD followed their democratic instincts, the bürgerlich blithely and blindly marched behind the swastika flag of the NSDAP, unable to see that Hitler actually meant what he said.

Marches had become a common occurrence since the beginning of 1932. The Iron Front marched to show the strength of the SPD and to discourage any Nazi thoughts of attempting to seize power by force. The plan of action in the event of another Nazi putscis designated the members of the Iron Front to become police reserves under the direction of the Interior Minister, Leuschner. ${ }^{3}$ with arms supplied by the police, the SPD had very few weapons in 
its possession, the Iron Front would act as a formidable deterent. Without the leadership, and more importantly, the guns held by Leuschner, the Iron Front would have a hard time defending Pfungstadt against a putsch attempt, if the putschists were armed. The leaders of the Iron Front and Reichsbanner, Albert wälke and his second in command Ludwig Clemenz, did not organize their members to operate independently of the state but through the state. This fact strengthened the Iron Front immensely, since Leuschner provided a strong symbol for the membership. The second half of 1932 began with the Iron Front ready to demonstrate that they were not afraid of a fight. In concerted action with other nearby Iron Front units, the group from Pfungstadt marched off to Darmstadt on July2 in order to participate in a large demonstration. 4 one of the central facts of the Iron Front member's life in those perilous days was the constant movement from one SPD meeting to another, from town to town, village to village. Pfungstadt's Iron Front had assumed the responsibility for the protection of several SPD local parties which were situated in less than friendIy areas. Quite often Sundays would be spent traveling to this or that demonstration either as a proponent or pro- 
tagonist of the particular political philosophy on display. Some hearty individual members even set out to distant meetings after their work was done for the day, often arriving back in Pfungstadt early the following morning only to repeat the process over and over again. Pifty-kilometer bicycle trips were a common occurrence. ${ }^{5}$ Another group that was often under way was the political cabaret die roten Spatzen (the red sparrows), an invention of the SAJ. The group had made its first appearance during the November, 1931, Landtag election, but only produced its cutting satire for Pfungstadt. By July, 1932, the group was traveling over many parts of southern Hessen in a rented truck, playing to packed SPD gatherings wherever it went. 6 The upcoming Reichstag election (July 31, 1932) would not be lost because of want of effort.

Realizing that the NSDAP could not be areamed away the volksfreund launched daily attacks against Hitler and the NSDAP. One area which received particular attention was Hitler's position in regard to the Jews. The biting satire of a July 5 article in the volksfreund contrasted his attacks on the Jews with his attacks on the "Marx1sts," concluding that "anything is possible with Herr Hitler."7 Anti-semitism played such a minor role in Pfung- 
stadt's history that it never became a large point in the Nazi program before 1933. The one notable incident involving a Jewish member of Pfungstadt produced no discernable echo concerning other Jews in the community. The butcher, Stern, a hard working and practical man, 8 had purchased large quantities of meat which he proceeded to sell below other butchers'prices, most often to the unemployed. In this manner he became the hero of the poor and the center of controversy. The murky line between financial jealousy and anti-semitism is very difficult to define in this case, because no direct assault upon stern for being a Jew was ever launched. The whole incident involved a former apprentice whom stern had fired. The man charged that stern was able to sell his meat at the low prices he did because he had acquired low quality, and at times, the man said, completely inferior, meat. An investigation of the charges by the state health office failed to reveal any poor meat, but the man kept up his campaign against stern, charging at one point that he had seen stern urinate on a sicie of beef before he cut it up to sell. The two years over which the struggle took place yielded no final result. 9 stern's threat to take the man to court silenced him for a time, and the inaugeration of the Third Reich 
ended Stern's chances to ever settle the matter, although the Nazis did not force him to close his shop once they had attained power. Anti-semitism was, at best, a peripheral issue in the years before 1933.

Throughout the years between 1929 and 1933 the average worker very infrequently studied the differences between the KPD and the SPD. He preferred to think of the working class as one united body, able to do battle with the Nazis with both fists punching together if the time should arrive when that would be necessary. 10 The leaders of the SPD took a dim view of such thoughts although they acknowledged that the KPD was violently antiNazi in Pfungstadt. The abiding fear that the KPD would only intensify its already powerful block of voters at the expense of the SPD predominated the thought for a very long time within the ranks of the SPD's leaders. They reasoned that the SPD was democratic, that the KPD was undemocratic, and that therefore they could not work together.11 The average member of the party was very dubious of that proposition. There was also the feeling of regret that the KPD had its members out of the Associated Union (the KPD was not associated with the Union, but individual XPD members were). Sensing the mood of 
the average worker and desiring to see some sort of oldfashioned cooperation reestablished, the leader of the Reichsbanner/Iron Front, wälke, and the leader of the KPD's Anti-facist League, Huxhorn, agreed to form a Joint Committee for Proletarian Unity at a huge meeting on July 8. Unanimity reigned at the gathering as a set of proposals for a joint program was unanimously approved.12 A very real threat to any NSDAP plans for Pfungstadt was created, for one must not lose sight of the fact that the total vote of the SPD and the KPD still represented a majority in Pfungstadt $(2,425$ votes, $52.38 \%$, in the June 19, 1932, Hessen Landtag election). The majority of the SPD/KPD male vote (approximately 1,200) was already part of either the SPD's or KDD's "fighting" groups: (SPD between 600 and 700; KPD between 110 and 140). The SA was outnumbered by an eight to one count at the very minimum. Huxhorn was very enthusiastic at the prospects of a Unity Front, going so far as to claim that "the importance of this question (the joint committee's plans) means more to us than the (July 31) Reichstag election."13 The sincerity of Huxhorn's statement was undoubtedly viewed with a great deal of suspicion by the SPD's leadership, but the fact remained that organs of the 
SPD and the KPD (the partiles themselves were not a part of the arrangement) had reestablished their first official contact in years.

On Friday night, July 15, the Unity Front staged its first public demonstration, with an impressive result. Over twelve hundred of Pfungstadt's own SPD/KPD members marched through the streets of Pfungstadt to the Rathaus square. At the Rathaus both Huxhorn and wälke delivered impassioned speeches, promising to rid Pfungstadt of the Nazi "pest". The crowd of two thousand men and women cheered lustily at the words of their leaders, while small groups of SPD and KPD people could be found everywhere discussing the implications of this unexpected new development. 14 Many were still enjoying their rediscovered similarities when word from the higher authorities of the Reichsbanner/Iron Front arrived that no more cooperation with the KPD would be tolerated. 15 The Unity Front was dead.

Barely two days after the abortive attempt to unite the workers, the Iron Front was back on the streets. on July 17 the members of the Iron Front marçhed to Eberstadt and then back to Pfungstadt where they held a rally near the train station. ${ }^{16}$ Before any more demonstrations 
could be scheduled, Chancellor von Papen* dissolved the Braun (SPD) government in Prussia which resulted in a tor tal ban of all parades and demonstrations in Hessen on July 22.17 The ban did not include meetings held within a hall or restaurant, so the Iron Front scheduled a gathering for July 25. Besides words of condemnation for Papen, the main speaker, schmitz (Köln), reminded the assembled crowd that the upcoming Reichstag election would decide if the workers were to be slaves of papen and his mentors or free men.18 The final Iron Front rally, before the Reichstag election, took place the day before the citizens were scheduled to go to the polls on July 30.19 The SPD's campaign was one of the most lively in years. Abuse against the SPD had filled the air; there were more street confrontations than ever before, while an urgent desire to come to a decision filled the minds and hearts of most members. The SPD had been caught looking silly after agreeing to join with the KPD in an all out assault on the NSDAP. This promoted some feelings of pessimism among tine ranks of the leaders as the days before the election waned. July 31 would be a real test for the SPD.

*Franz von Papen had been appointed Chancellor of Germany by president von Hindenburg on June 1, 1932. 
Among the ranks of the KPD a feeling of optimism reigned. The KPD more than held its own in the back streets of Pfungstadt with the occasional SA man who challenged a KPD distributor of handbills. In addition the KPD had won more respect for the attempt to unite forces with the SPD.20 A series of informal restaurant and street corner meetings had given Huxhorn and other KPD leaders the chance to expound their hatred of facism and recommend a sweeping solution. As a capstone to their pre-election efforts the KPD caused the greatest street confrontation, riot would be a better word, in the history of Pfungstadt. The basis for the riot was the growth of an overwhelming dissatisfaction with the existing conditions among the unemployed. As unemployment subsidies went down, the tempers of the unemployed went up. The KPD had attempted to incite the unemployed to a more militant stand when they had distributed leaflets accusing the mayor of withholding funds from the unemployea.. The foundation of the riot on July 29 was again a rwnor about the unemployment funds. The rumor spread that there was no money for the unemployed. Men, women and children showed up at the "stock-exchange" (as the unemployment office was called) early in the morning 
to confront the official in charge. He quickly telephoned the mayor who, in turn, informed Peter Crößmann. Crößmann rushed to the scene to find negotiations going on between the mayor and the leaders of the unemployed (Huxhorn and Herth). 21 By noon the money had begun to be distributed, but those that had collected their money remained on the street in front of the office talking to those who had not yet received their payment. The fact that the large crowd did not disperse greatly excited Pfungstadt's police who finally decided to call in reenforcements--the schupo. The arrival of the police provided the spark which had been lacking before. Armed police facing a crowd of dissatisfied citizens elong with many children presented the leader of the police with a difficult decision, since an unintended shot could very easily kill a child. Pleas for the crowd to disperse were not followed, so the police moved forward in an attempt to send the people home. The - crowd responded with their fists and the riot was on. 22 In the confusion one of the cars which had carried the police to Pfungstadi was turned over. Huxhorn and his associates dio not participate in the riot, mindful as they were of the results of the 1928 "Kottmann incident".23 When the schupo finaliy left the scene of the altercation 
they only had three people in their cars, none of them leaders of the confrontation. While the KPD's action at the "stock enchange" produced a strong reaction in the ranks of the middle class, the unemployed felt a strong sense of comradship with the KPD. The leaders of the KPD demonstrated that they would not be faced down by any threat; they would take action where other people only spoke of relief. However tortured such logic might be, it influenced the unemployed as much as the disjointed ideas had moved the middle class.

The principle reaction of the bürgerlich cane from the Kommunale Vereinigung Pfungstadt which played up the "terror acts" of the KPD. Besides protesting against the fear that supposedily stalked the streets, the vereiniqung charged that a "black list" of patriotic (national-thinking people) men had been drawn up. From the list a certain number were to be shot charged the Vereinigung. They asked the "respectable" members of the community to immediately report any act against themselves to the police for action. 24 The advertisement of the Vereiniqung said more than any protest of the NSDAP could have. It clearly suggested that there were only two parts to the community, the esteemed and the disorderiy. The community was clearly 
split, split deeper than any normal solution would quickly resolve. The intolerable poljtical tension which was conducive to the parties with extreme answers caused tne Anzeiger to reaffirm its neutrality once again before the election. 25

clouds filled the sky on July 31 and it eventually began to rain as the last voters were marking their ballots, but quiet prevailed on the streets. No incidents, no confrontations, no fights marred the serenity of Pfungstadt. 26 since only $4.91 \%$ of the voters had failed to select either the NSDAP, the KPD or the SPD in the last election, the major impact of voting trends was expected to continue in that area. Indeed it did. On July 31 the NSDAP/KPD/GPD captured $91.61 \%$ of the votes. Depending upon one's self-serving interpretation of the election, the Nazis: 1) gained seventy-nine votes more than they had had on June 19, and therefore kept their momentum; or 2) lost nearly one percent (July $31-41.49 \%$, June $19-42.46 \%$ ) of the total votes cast. Nearly every observer regarded the first interpretation as being more valid since the loss really indicated a reintroduction of SPD/KPD voter's into the election process than a real reversal of Nazi voting support. Climbing from 2,425 total 
votes $(52.88 \%)$ the SPD/KPD recorded 2,639 electoral supporters $(54.64 \%)$ on July 31 . This vote total still did not equal the all-time high vote count of 2,651 on November 15, 1931, but confirms the earlier assumption that onIy a minute fraction of the working class vote was slipping into the Nazi column. Both the KPD and the SPD received a shot in the political arm, the KPD achieving their greatest electoral success to date in pfungstadt. The most notable returns were:

RESULTS OF THE JULY 31, 1932, REICHSTAG ELECTION 27

\begin{tabular}{lrrrr} 
KPD & 1,069 & $(917) *$ & $22.13 \%$ & $(19.19 \%)$ \\
SPD & 1,570 & $(1,483)$ & $32.51 \%$ & $(32.45 \%)$ \\
NSDAP & 2.026 & $(1.947$ & $41.95 \%$ & $(42.46 \%)$ \\
OTHERS & 164 & $(225)$ & $3.39 \%$ & $(4.91 \%)$ \\
\cline { 2 - 3 } & 4.830 & $(4.586)$ & &
\end{tabular}

A record number of people had also gone to the polls $(4,878)$ producing a near record percentage of eligible voters exercising their right to vote $(95.04 \%)$. While the SPD could cheer themselves with the news that their voters were merely sitting out the Landtagelection and would return to the SPD, the fact that the negative election.

*Returns from the June 19, 1932, Hessen Landtag 
vote (KPD plus NSDAP) showed no signs of abating. Along with several other records, the KPD plus NSDAP vote total seE another record as 3,095 people (a generous 64.8\%) selected them to represent their frustrations in the Reichstag. of particular importance in the election was the leveling off of the NSDAP's percentage of the vote. At the height of their power the traditional middle class parties had amassed $42.46 \%$ of the voting public $(1,715$ votes out of 4,049 in the May 4, 1924, Reichstag election). The implication was that the Nazis had reached the end of their poll of supporters. With the SPD seeming to have shored up its support, the outcome of any new election looked fairly predictable. Elections did not seem to offer the opportunity, in the near future, to break the political $\log$ jam.

Encouraged by the apparent stability of the SPD, a Constitution Day celebration was planned for August 11 despite the fact that no funds were forthcoming from the town council and it was no longer an official holiday. Meeting ir the yard of the school, since no parade preceeded the festivities, a moderately large crowd listened attentively as the school teacher, Lang, described the constitution as having given the people freedom. He 
warned that freedom must be translated into an end to party strife and disintegration, while the unity of the state took first priority. 28 The pale shadow of the celebrations of previous years was nothing more than a futile gesture against the rising tide of people calling for a solution, any solution to their problems. Few people were interested in debating the finer points of the constitution at a time when they had to scrape every day just to eat. The robbery of potatoes from the farmers and meat from the butchers had increased right along with the unemployment in Pfungstadt. Few people believed that things could go on like they were for a sustained period of time--the depression needed to be conquered.

In the midst of the political unrest, the annual budget debate reared its ugly head. The ugliest aspect of the budget was point forty-three--town unemployment benefits. From a low of twenty-five thousand marks in $1928 / 29$ (2.93\% of the total budget) the benefits being paid went to three hundred twelve thousand marks in $1931 / 32(33.62 \%$ of the total budget). 29 As the budget debate opened the outlook for an improvement in the fiscal situation it was nowhere in sight. A broad discussion of the entire budggt:led to the inevitable confrontation between the bür- 
gerlich and the SRD/KPD over the town unemployment benefits for the coming budget year. After two hours of intensive debate the Unemployment committee's suggestion that the unemployment benefits did not mean anything unless there was enough to maintain a decent standard of living was adopted. This meant that no cut would be made from the level which was in force during the budget year 1931/32. It also meant that the appropriation for the payments would have to exceed four hundred thousand marks $(421,000.00-44.78 \%$ of the entire budget $) .30$ one bright spot in the gloomy fiscal picture was the town's debt which actually decreased from a post-war high of over seven hundred seventy-four thousand marks in July, 1930, to somewhat under seven hundred forty thousand in July, 1932.31 (For a complete breakdown of the public debt 1928-1935 please see page 466.)

Discussion of the budget, which had begun on July 5, was postponed until september 6 at which time the council began to vote on the individual points of the budget. At the close of the council session it had become apparent that the KPD's proposals were even further reaching than the previous year, while the SPD seemed less eager to support the KPD even on the most nominal 
points of the budget. The SPD had assumed that the depression would come to an end soon during 1930 and 1931 and that the midale class could pay more taxes so that the suffering of the unemployed could be minimized. By 1932 the SPD realized that all of the normal tax channels were closed to further enlargement. The riddale class of Pfungstadt was not as hard struck by the depression as the workers, but at the same time the KPD view that the bürgerlich could bear the entire burden of the unemployment through higher taxes was not true. The SPD, realizing that the middle class could not pay, simply adopted a fiscal position much closer to the middle. ${ }^{32}$ But there was no long a "middle" middle ciass to greet the SPD on their arrival. The bürgerlich had either resigned themselves to serving out their terms until the scheduled town council elections in 1933, becoming rightists in their own manner, or becoming members (or associates) of the NSDAP. Both Steinmetz and Martin had certainly elected to follow the last course of action by the second half of 1932.33 under the guise of the Kommunale Vereiniqung Pfungstadt the two men had carried on a brilliant running battle with the SPD and the KPD; they continued the struggle over the $1932 / 33$ budget with a ferocity that outdid their previous efforts. 
Charging that the budget was drastically out of balance the Vereinigung sent a letter to the kreisamt requesting that the kreisamt reject certain parts of the budget when it reached their office. ${ }^{34}$ Employing a fantastic slight of hand act, Martin denied that the bürgerlich council representatives were associated with the Vereinigung when he was closely questioned by the SPD members of the council on september 21 at the council session. After plowing their way through the maze of conflicting proposals which accompanied each point in the budget the council finally voted on the whole budget more than two months after it had first been introduced into the council. only the KPD members of the council voted against the budget while the SPD and the middle class joined forces to see that the budget was accepted. 35

When the Kreisamt submitted its analysis to the council at the october 3 council session, Martin was high1y upset. The Kreisamt generally approved of the council's 1932/33 budget, but pointed out that some people were paying property taxes which were below the kreis average. These, the Kreisamt decreed had to be raised, but those that were above the average had to remain at that level. Martin strongly objected to the "interference" of the 
Kreisamt. 36 Because of the serious lack of money the council could only approve work for thirty men on a bicycle path to Darmstadt. Considering the fact that seven hundred and thirty-nine men and women were on the town's welfare roles this was a small concession indeed. Other projects were impossible to fund. Workers for the bicycle path project were to be supplied by the Free Work Service which was also to be part of another project of immensely larger proportions. The Anzeigex had, just a few weeks earlier, reported plans for the construction of the Hafraba autobahn (Hamburg-Frankfurt-Basel) through some of Pfungstadt's forest and fields. 37 Depending upon the construction firm awarded the contract to build parts of the autobahn near Pfungstadt, a large number of the unemployed could conceivably find jobs. Until the plans could be approved the council still had to deal with the hash of fiscal realities. At the october 17 council meeting the representatives were forced to raise the Bürger tax because of the state threat to cut off funds in the event the council did not approve it. Aiso approved was a twelve percent cut of all officials' pay. ${ }^{38}$ The disturbing financial facts of life could not be neglected by the council for a moment. 
The tensions and frustrations of the middle class found its most potent outlet in the NSDAP. The fiscal difficulties of the town only exasperated the already highly charged political atmosphere. The NSDAP kept the pressure for change at a fever pitch with frequent meetings at which the speakers condemned the "Marxists" and trumpeted Hitler's solutions. Also of interest to the NSDAP was the Reichstag election slated for November 6 . A September 7 meeting featured the Reichstag member, Kern, who was insured a respectable audience as all of the NSDAP's members had been ordered to attend the meeting. 39 The spread of Nazism to the younger generation of Pfungstadt was very limited. Flthough the Hitler Jugend (HJ) had been founded in 1932 they never showed themselves in public or at the schools. There was never any trouble with the HJ in the schools before 1933. The only knowledge that the general public gained of the group before 1933 was the Anzeiger report of ten boys and three giris taking part in a youth day of the NSDAP at Potsdam in october. 40 By late 1932 the lack of a HJ or Nazi showing in Pfungstadt was certainly not for lack of confidence. on october 23 the party scheduled a public meeting to give the Reichstag member, Bartholomäus, the chance to 
describe "The fall of Marxism." He claimed a special insight into the intricacies of the problems since he claimed to be a former KPD member and Union leader. The meeting was well attended, in part claimed the Volksfreund because the NSDAP had scheduled the meeting at the same time as the Iron Front was attending a rally in Darmstadt. This they claimed was the basis of the challenge of the NSDAP to the SPD to attend the meeting. Aside from the false challenge of the NSDAP, the SPD claimed to have overheard ore NSDAP speaker explain the righteousness of the Nazi cause with the words: "Jesus Christ and Adolf Hitler are fighting with us."4l Exactly what the NSDAP was fighting for remained vague for the vast majority of the over two thousand people who voted for the NSDAP on election day, Party membership strength stood at about one hundred late in 1932.42 These official party members were strong advocates of the more radical thoughts of the party, while the broader mass of supporters were generally interested in only one or two aspects of the party progran. Some were against the department stores in Darmstadt, feeling that they unfairly burdened the small Handwerker firms in Pfungstadt; others complained about the tax structure which they felt 
the SPD would not change. Very few accepted the words of the party literally. 43 Those who did, feverently believed, although even within that group there were constant di.sagreements and bickering. Party discipline was under the direction of the ortsgruppenleiter, Wilhelm Gräff; SA discipline was enforced by the commander of the SA, Homburg. Graff was nominally the leader of the entire NSDAP, although his power was often undercut by others who reported that he drank to excess. 44 other areas of NSDAP activity were either unorganized or only weakly represented in Pfungstadt.

The NSDAP Ortsbetriebszelle was one such structure. It was only partially effective in its role, and then only with middle class "workers" who wanted to lead a working class cleansed of "Marxist" influence. An October 25 meeting of the group produced only chuckles not a response from pfungstadt's workers. 45 The main thrust of the NSDAP remained with the middle class voter. On November 1 the NSDAP held its last voters meeting with the main theme, "Von Papen or Adolf Hitler" before a large audience. Featuring a strong attack on Papen the meeting was filled with charges that Papen was responsible for the terrible situation of the middle class. claiming that only a 
reintroduction of workers into the economy, under the leadership of Adolf nitler, was the answer. Landtag member Klostermann promised that only the NSDAP could "lead the German people out of the problem of hunger, hatred and misery." He also characterized the struggle as one between the private-property-loving and Christian National Socialist and communism.46 This view was mirrored in many circles, where the discussion was whether the "communists" (KPD/SPD) or the NSDAP would win power in Germany.47 Other alternatives were either forgotten or regarded as insignificant. The Nazis had done their homework well; the bürgerlich were so wrought up in their world of upside down logic that the excited words of the Nazis seemed reasonable.

The basic SPD commitment to democracy never wavered during the long period of sustained political anarchy. Dents were made in the SPD ranks; twenty-six percent of the SPD electorate had wandered into the KPD column between 1928 and 1932, but a solid block of voters (July 31 Reichstag $-1,570)$ still stood behind the social Democrats. And the SPD members were never scared off the streets or cowed into cancelling any of its public meetings. A September 3 public meeting of the Iron Front/SPD demonstrated 
to the people of Pfungstadt once again that the SPD would not bow to denagogic tactics. There was no question of the SA/SS driving the SPD physicaliy out of town because of the overwhelning superiority of Iron Front/Reichsbanner/Antifacist League (KPD) numbers. The leaders of the SPD were edgy, fearing that the NSDAP would attempt to take power in Germany through physical force, but surely not in Pfungstadt. Plans for the defense of the city hall, water and electricity works, the post office, the train station, and all important roads leading to and from Pfungstadt stood ready. Only the signal from Interior Minister Leuschner was needed to send the vast majority of the working class into the streets to defend the ideals they had been taught 48 Pessimistic reports about the growth of Nazism in other parts of Hessen were tempered by the optimistic outlook for the workers in Pfungstadt. Factually, a significant portion of the KPD voting strength came from SPD members who felt that the KPD would more quickly join battle with the NSDAP than the SPD. Thus these voters were not entire1y lost to the SPD, if the SPD projected itself into the role of a more militant group which was ready to fight at a moment's notice. An article in the volksfreund that two Nazis had been arrested in Pfungstadt for carrying 
guns only gave more emphasis to the desire of many to prepare for all eventualities.49 Also accentuating the alternatives were Young Socialist Workers who met to discuss the topic, "Democracy or Dictatorship" on October 6.50

If the SPD in Pfungstadt was tired of Reichstag elections they certainly did not reveal the fact in the weeks before the November 6 election. Part of the SPD's determination must have come from the activities of the central committee of the Hessen SPD. On October 23 the SPD opened its "First Week of struggle" with a giant rally in Darmstadt. Hessen minister-president Adelung and Carlo Mierendorff, the SPD's leading candidate for the Reichstag, and other speakers delivered ringing condemnations of Nazism at the demonstration. The largest part of the Iron Front from Pfungstadt went to Darmstadt 1 Besides taking part in the campaign in pfungstadt many of the SPD spent every free evening traveling from one SPD meeting to another. Leading SPD officials from Pfungstadt spent countless hours addressing rallies, marches, and meetings $a 11$ over southern Hesse-Darmstadt. 52 Election weariness simply did not exist in the political vocabulary of Pfungstadt's SPD. Attesting to the import- 
ance of Piungstad's's SPD was minister-president Adelung's adaress in peungstadt on october 26. Before a packed house he aiscussed "The working class needs bread and work, while papen's government brings us only constitutional changes and steals cur political rights." The Iron Front praised Adelung for sticking to facts and avoiding slogans in a ietter to the Arzeiger. 53

During the "Second Week of struggle" which began with another rally in Darnstadt, adoressed by Leuschner on October 29, the SED held a huge meeting with Pringsheim (Darmstadt) as the main speaker. Included in the festivities of the night was a satirical play by the "Rote spatzen" and songs from the Volkschor. As the days before election slipped away, the Volksfreund hurled vicious attacks at Hitler, Papen and Thälmann while it stressed more and more often the need for real socialism. ${ }^{54}$ At the same time as the Volksfreund was expounding the need for socialism, the KPD was reminding the working class electorate that the SPD had been instrumental in the defeat of the KRD's town council profosals during the budget debate. Such below-the-belt tactics were not foreign to the KPD which campaigned with force when they met opposition on the streets. Although demagogic outbursts 
were not unknown to the KPD, the leaders of the KPD did not resort to the stimulation of racial prejudices. While they sometimes lost sight of the NSDAP because of their opposition to the SPD, the leaders of the KPD realized that they were part of the larger working class. Coordination of eventual tactics in the event of a Nazi coup d'etat did take place between Huxhorn and Albert Wälke (Reichsbanner/Iron Front). 55 During the days before the election the animosity between the SPD leadership and the KPD leadership definitely increased, but the average worker did not consider this reason enough to break lifelong friendships or engage in physical disagreements.

The old middle class parties staged another brilliant non-campaign. Not one public meeting was scheduled because of the futility in the face of the Nazis and/or personal admiration for the effect of the NSDAP on the "Marxists."56 The only break in the non-campaign was a meeting of the rightwing Christlich-soziale volksdienst but did not find much support. Fists replace money when the latter runs low as it did in the final days of the campaign. Pasting political handbills up in Pfungstadt had to be the most dangerous occupation in 1932, as 
from the Reichsbanner, KPD and $S A$ roamed the streets at night destroying the opposition's slogans and engaging in a limited number of physical confrontations. 57

Nearly ninety-six percent of the votes went to the NSDAP, KPD, and SPD on November 6. The Nazi vote total increased by only twenty votes, indicating that they had reached the outer limits of their support. The SPD vote total slipped by almost one hundred and thirty, while the KPD reached its all-time high with one thousand and fortyeight votes. A slight drift to the KPD by SPD voters, coupled with the lack of Nazi growth, left the town confronted with the same situation as before the election-stalomate. The search for a political solution in Pfungstadt would have to go on.

RESULTS OF THE NOVEMBER 6, 1932 REICHSTAG ELECTION

$\begin{array}{lrrrr}\text { KPD } & 1148 & (1069)^{*} & 23.67 \% & (22.13 \%) \\ \text { SPD } & 1446 & (1570) & 29.81 \% & (32.51 \%) \\ \text { NSDAP } & 2049 & (2026) & 42.24 \% & (41.46 \%) \\ \text { Others } & 208 & (165) & 4.31 \% & (3.39 \%)\end{array}$

The election aic not remove the unemployed from the

* Resulte of the Reichrtag election which was held on July 31, 1932. 
streets nor produce any economic recovery. The KPD which had sponsored a number of unemployment meetings in the mouths before the election, took their improvement at the polls as a sign that they were headed in the right direction. Although they were at loggerheads with the SPD over many issues, the cooperation between the two groups was solid in the town council when it came to unemployment questions. Without the prospect of a decrease in the unemployment in sight both groups pressed the town council to allocate more funds or goods to the unemployed in order to cut down the theft of goods from several stores in Pfungstadt. Wood cutting by unauthorized people reached a peak in the bitter months of late 1932. The KPD encouraged the unemployed to press their demands in the town council in a number of meetings in November and December, while the SPD held meetings on November 9 and December 9.59 In addition the SPD did not slow its political activity even after their disappointing showing in the November 6 eisction. The SPD and the rron Front met on November 19 to hear the chairmar of the SPD Landtag members, zinnkann, declare that the SPD had not lost its proletarian interest as the KPD had charged. On November 26 the Iron Front gathered to hear the songs of the 
Volkschor and watch the "Roten Spatzen" distribute a generous portion of political satire to the audience. The final SPD meeting of the year dealt with the everpresent problem money had created for the town council and the unemployed. 60 words of encouragement were not to be found in the SPD assembly.

Stunned by the obvious leveling off of their electoral support the NSDAP failed to stage even one public meeting for the rest of 1932. The optimistic promises of eminent governmental power which the NSDAP membership had heard since the spring of 1932 had turned out to be only false predictions. Unable to gain power "legally" a small portion of the NSDAP desired to take more direct means to achieve their ends.61 This was confined to an insignificant portion of the NSDAP but provided an interesting glimpse of the unrest that haunted the NSDAP. To take their minds off electoral politics for a time the NSDAP assembled a notable number of members to take part in a November 20 day of "Remembrance for the Deceased Soldiers." The Protestant minister, Zinn, held a special church service at the war nemorial in the town's cemetery for a large group of SA members and Krieger und Militäryerein_followers.62 The NSDAP attempted to add 
more marks of respectability to j.ts image through its Frauenschaft which set out to collect money, clothes, and food for the poor. On December 17 the NSDAP then held a Christmas celebration where selected members of the community were presented with the goods contributed over the past month. 63

By the time 1932 drew to a close it was clear that the people of Pfungstadt, no matter what their political inclination might have been, were no closer to generatIng a political solution for themselves than they had been when 1932 began. The little mar who sat on the side of the street through the day because he could find no work, and the businessman who could not see 3 brighter outlook on the horizon, were drained of the energy to direct the political process. Nearly everyone wanted a solution; no one knew where to find one in pfungstadt. 
CHAPTER $\mathrm{X}$ - FOOTNOTES

Interviews with Gottfried Helene, Wilhelm Kaffenbe:ger, Heinrich Schaffner and Julius Winkler.

${ }^{2}$ Interviews with Ludwis Wenz, Adam Ruckelshausen and Jacob Deip.

${ }^{3}$ Interviews with Georg Liebig, Peter cröBmann and August Hechler.

${ }^{4}$ HVF : July 2, 1932.

${ }^{5}$ Notes from the private file of August Hechler.

${ }^{6}$ August Hechler, Die sozialistische Jugendbewegung in Pfungstadt in 75 Jahxe SPD Ortsverein Pfungstadt, , 1967), pp. 81-83.

${ }^{7}$ HVF : July $5,1932$.

${ }^{8}$ Interview with Fritz Feidmann.

${ }^{9} \mathrm{PA}$ : July 9, 11, 1930, October 30, 1931 and November $16,17,18,19,23$ and 25, 1932.

${ }^{10}$ Interviews with Karl Emig and Johann Kölsch.

${ }^{11}$ Interviews with Peter Crößmann and August Hechler.

12 HVF : July 9, 1932.

13 Notes from the file of Heinrich Huxhorn.

${ }^{14}$ PA: July 16, 1932 and HVF: July 19, 1932.

${ }^{15}$ Interviews with Peter Crößmann, Karl Emig and Georg Herth. 
16 HVF : July 16, 1932.

${ }^{17} \mathrm{PA}:$ July $22,1932$.

${ }^{18} \mathrm{PA}$ : July 25, 1932 and HVF: July 25, 1932.

${ }^{19}$ HVF : July $30,1932$.

${ }^{20}$ Interview with Karl Emig.

${ }^{21}$ Interview with Peter Crößmann.

22PA: July 30, 1932 and HVF : July 30, 1932.

${ }^{23}$ Interviews with Maria Schulz and notes from the file of Heinrich Huxhorn.

24 pA: July 23, 1932.

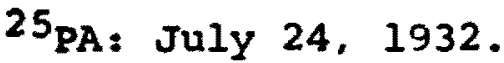

${ }^{26} \mathrm{PA}$ : August 1, 1932.

27 Ibid.

$28_{\mathrm{PA}}$ : August $12,1932$.

${ }^{29}$ Rechnung über Einnahme und Ausqabe der Gemeinde Pfungstadt für 1928 and 1931, pp. 25 and 96 .

30 PA: July 5, 1932; HVF: July 6, 1932; PGSP: July 4, 1932, pp. 368-370.

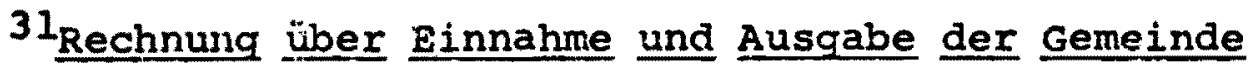
Pfungstadt für 1928, 1929, 1930, 1931 and 1932, pp. 124$126,129-132,131-134,145-143$ and 157-150.

${ }^{32}$ Interview with August Hechier. 
${ }^{33}$ Interviews with Luise Steinmetz and Heinrich Sand and PA: November 1, 1935.

${ }^{34} \mathrm{PA}$ : September 15, 1932.

35PA: September 16, 1932; HVF: September 17, 1932; PGSP: September 15, 1932, pp. 376-380.

${ }^{36} \mathrm{PA}$ : October 4, 1932; HVF: October 5, 1932; PGSP: October 3, 1932, pp. 383-385.

${ }^{37}$ PA: September 9, 1932.

38 PA: October 18, 1932; HVF: October 20, 1932; PGSP: October 17, 1932, pp. 386-388.

${ }^{39} \mathrm{PA}$ : September 7, 1932.

40 $0_{\mathrm{PA}}$ : October 3, 1932 and interviews with Heinrich Schaffner, Julius Winkler and Heinrich sand.

41 PA: October 22 and 24, 1932 anà HVF: October 21 and 25,1932 . sand.

${ }^{42}$ Interviews with wilhelm Kaffenberger and Heinrich

${ }^{43}$ Interviews with Maria Schulz, Jacob Brauer, Adam Ruckelshausen and Heinrich Sand.

${ }^{44}$ Interviews with Jacob Hanbuch, Heinrich Sand and Heinrich Schaffner.

45 Notes From the file of Hans otto and interviews with Heinrich Schaffner, Peter crößmann and Georg Herth.

$46_{\mathrm{PA}}$ : October 31 and November $3,1932$. 
${ }^{47}$ Interviews with Gottfried Helene and Jacob Brauer.

48 HVF : September 7, 1932 and interviews with peter crößmann, Georg Herth and Georg Liebig.

$49 \mathrm{HVF}$ : September $16,1932$.

$50_{\mathrm{HVF}}$ : October 4, 1932 .

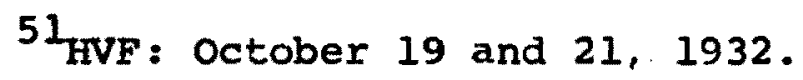

52 Notes from the file of August yechler and interview with Peter Crößmanr.

$53 \mathrm{HVF}$ : October 25 and 29, 1932.

${ }^{54}$ HVF : November 2 and 5, 1932.

55 Notes from the file of Heinrich Huxhorn and interviews with August Hechler, Georg Liebig and Georg Herth.

56 Interview with Julius Hofmann.

${ }^{57}$ Interviews with Jacob Delp, Heinrich Schaffner and Georg Liebig.

${ }^{58} \mathrm{PA}$ : November $7,1932$.

${ }^{59}$ Notes from the file of Heinrich Huxhorn; interview with Georg Herth; HVF: November 11 and December 10, 15, 17 and 31, 1932 .

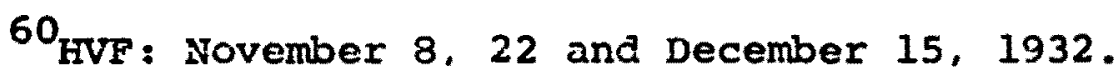

${ }^{61}$ Interviews with Heinrich Schaffner and Heinrich sand.

62 PA: November 19 and 21, 1932 and FVF: November 22,1932 . 
${ }^{63} \mathrm{PA}$ : December 19, 1932. 
PART III

THE NAZI TRIUMPH

1933 To 1935 
* ChAPTER XT

THE FINAL AGONIZING ACT - JANUARY AND FEBRUARY, 1933

Confined in a prison of hatred and uncertainty, the people of Pfungstadt began the fateful year 1933. Although the Anzeiger wrote that, "We cannot give up, we must hope for better times," few people really believed that a solution to their problems lay near at hand. 1 The Hessen government pointed out that the low point of the depression was over and that a slow improvement in the economy could be expected, but there had been similar predictions in previous years. 2 people did not know what was going to come. The once familiar signposts of life had been altered or destroyed. Faith had been damaged. In such a situation people understandably lost their way, although in a few cases their blindness was more selfinduced than anything else. Without the stable beacons of trust to light their welcome way, the middle class fell into the trap of allowing their emotions to run unchecked over their intellects. The working class saw the same phenomena occuring though to a lesser degree since the SPD 
kept their heads. The mood of the day was ugly; the old normalcy was gone; the new normalcy had matured into something intolerable; the stage was set for the final agonizing act.

A strong tradition of unselfishness coupled to the stable reserves of courage which the SPD had displayed on other momentous occasions drove the SPD to continue its activities with no loss of vigor during the first two months of 1933. Whether it was an SAJ meeting to discuss the teaching of Karl Marx or the local Reichsbanner leaders gathering in Eberstadt to organize their strategy, the SPD never gave up its intention to remain in the thick of the political fight for Pfungstadt. 3

Life's pleasant distractions also gave the people something other than politics to involve themselves in. The SAJ opened an outdoor ice rink on January 21 . Lighted at night and charging children only RM .05 admission, it drew a large contingent of eager youngsters out into the chilly air of winter. The soccer fan could revel in the knowlecige that the Arbeiter Fussballverein team led its league. ${ }^{4}$ But these were small consolations for the promise of work and food for many of Pfungstadt's inhabitants.. Money, the lack of it, was at the root of Pfung- 
stadt's problems declared the chairman of the SPD during the yearly general meeting on January 18. This overriaing difficulty was echced in the yearly Reichsbanner meeting which occured on January 21. People could not pay their dues because they simply did not have the ready cash. 5 Looking back on 1932, the SPD/Reichsbanner leadership acknowledged that they had never invested so much time and money in the many years the SPD had existed in Pfungstadt. Despite the optimistic words of hope, the general feeling was that the party had done everything possible to meet the challenge of the day--without being able to register tangible results. Nevertheless a change in party and Reichsbanner leadership was not considered at the meetings since the people knew that their leaders had spent more time on party business than any man could expect. The leadership remained respected and esteemed despite the party's setbacks in 1932.6

Heinrich Huxhorn and his KPD associates were not ready to abandon the town of $P$ fungstadt to the NSDAP either. A combination of an iron will and endless hours of work had produced the largest KPD vote returns in the history of Pfungstadt during 1932. None of the KPD membership saw any reason that the steady growth of the KPD 
power would not continue, while others argued that the KPD's time was surely coming. ${ }^{7}$ The most powerful weapon in the KPD's arsenal throughout the years 1929-1933 was unemployment. Unemployed workers were the basis for the expansion of the KPD. Therefore, to utilize the unemployed as political tools for the eventual take-over of power came naturally to the KPD. Huxhorn sponsored a wide range of unemployment meetings and street corner discussions in Pfungstadt and expanded his scope to all of Darmstadt county after he was appointed chairman of the KPD's unemployment commission for Darmstadt. 8 His masterly, cunning, tactical mind was then challenged to produce the same results for the rest of Darmstadt county as he had produced in Pfungstadt. Those that might have believed that the task was too great for the man soon had to reacknowledge Huxhorn's organizational genius. In the biting cold on the morning of January 24 over seven thousand of Hessen's unemployed, including a contingent from Pfungstadt, trecked toward Darmstadt from several directions. Arriving almost exactly at noon with the slogan, "We demand work and food!" broadly displayed on signs, the crowd surged onto the Louisenplatz. The leaders of the demonstration demanded, unsuccessfully, entrance to the 
official buildings which faced onto the square. Unable to attain their immediate goals a delegation of the crowd managed to arrange to meet an official delegation of the Hessen government later in the afternoon, after which the crowd peacefully disbanded to return to their homes. 9 Huxhorn considered this rally the highpoint of his years of work in Pfungstadt, a masterpiece of coordination and timing. Huxhorn's image among the unemployed of pfungstadt increased immensely. 10 At the same time the demonstration revealed the inability of the KPD to rally more working class representatives to their side. caught in the trap of predicting the end of capitalism through a disintegration of the present state, the KPD could not see that the designs of the Nazis meant anything more than a replacement of one set of "capitalists" by another. The KPD was not prepared to see that the NSDAP could stay in power for any length of time, nor were they prepared to moderate their views in order to accommodate the SPD within a unified system of antiNazism for any period of time. Seeing their own goal as the replacement of the Weimar Republic by a Soviet style system, they had effectively closed the bridges that would be so essential if the NSDAP successfully challenged both 
the KPD and the SPD at one time. This put the entire burden of defending the Weimar Republic in Pfungstadt upon the shoulders of the SPD. Since the middle class had made their opposition to the democratic style of socialism plainly evident, an effort to defend democracy in Pfungstadt had two strikes against it before Hitler was ever vested with the administrative apparatus of the national government.

Having utterly failed the test politically, the middle class fell into a moral stupor during the months January and February. Only a reminder in the Anzeiger that the Handwerker was facing his most serious (fiscal) test in years, plus a plea to young craftsmen not to open any shops in Pfungstadt, relieved the pressure which they felt upon them.1.1 The farming community tried to influence the course of events at the highest levels during the period. On January 4 the "neutral" Landbund sent a telegram to Hindenburg demanding that "his excellency make the government stop talking and produce some action for the hardpressed farmers."12 This burst of energy played out, the farmers went back to their daily affairs. There was virtually no political activity by the old 
middle class parties, although some leaders hinted that the Nazis had lost their momentum and would never come to power in Germany. The NSDAP did seem to be inordinately quiet throughout January. Only the burial of a SA man on January 15 provided the NSDAF with public exposure. Impressive exposure it was considering the approximately one thousand NSDAP men who marched behind the coffin to the cemetary. The Protestant ninister, zinn, said a few brief words, while the main oration was delivered by a SA man who declared that the funeral was another example of a Volksgemeinschaft which recognized neither rank nor class. 13 A strange quiet then redescended among the ranks of the NSDAP. The lack of NSDAP activity signified both a drop in the level of self-confidence and lack of concrete aims. There was no election in sight to focus upon, no particular action in the town council. The party needed new instruction if it was not to start the process of disintegration. One must not forget that the vast majority of the NSDAP's electoral support had never been turned into solid party members. Some had joined the party, the majority had taken a wait and see attitude. If the Nazis did not produce the results they had promised for so long there was nothing to hold their supporters to 
the party. 14 This then was the main worry of the party leaders during the month of January. Someone had to supply a reason for their continued political dominance. President von Hindenburg and his associates were to supply it.

The news that Adolf Hitler had been appointed the chancellor of Weimar Germany reached the town of Pfungstadt on January 30. The Anzeiger carried only a small extra article because it was ready to go to press by the time the news was received. The excitement among the NSDAP members was great. The party secretary, Sand, ran from house to house announcing the news to various members. The same evening the loyal party members gathered at the restaurant Zur Krone to hear Pfungstadt's SA leader, Homburg, and the ortsqruppenleiter Gräff offer their appraisal of the change of government. At 8 P.M. the festivities of the day were climaxed by a torch light parade through the streets. 15

The stunning news of Hitler's appointment produced no panic within the ranks of the SPD or the KPD. As soon as the announcement that Hitler was chancellor arrived, the SPD plan for stopping a Nazi putsch went into effect. Guards were posted on all of the main roads leading into 
Pfungstadt, the water and electricity works were watched and the post office (telephone communications) and the town hall were surrounded. ${ }^{16}$ No public meeting of the SPD took place. The KPD leadership moved immediately to counter any NSDAP attempt to seize power by moving to discuss joint action with the SPD and Reichsbanner leadership. The average SPD member had been waiting for something to happen; the average KPD man had been waiting, but theo went into the streets for a parade and then gathered for a meeting. The parade took place at 5 P.M.; Huxhorn and other KPD leaders met the Reichsbanner/Iron Front leader Wälke and his subordinates at 8 P.M. to plan a unified response to any NSDAP push for power. 17 wäIke and kuxhorn agreed that they would have to act in unison to prevent the NSDAP from assuming dictatorial power, but wălke was not ready to commit himself and his associates completely until he received orders from "above." The Reichsbanner/Iron Front response to the NSDAP would depend upon Leuschner and his decisions. If he was prepared to fight the NSDAP then he only had to give the order and the working class of Pfungstadt would have rallied around the Rëichsbanner to defend the Weimar Republic. ${ }^{18}$ The in- 
ability offälke to join with the KPD stemmed in part from his lack of knowledge of the exact intentions of the KPD. In such a confusing and pressure-packed situation, the KPD became a wild card. They certainly were not going to support the NSDAP physically in a takeover attempt, but at the same time what they would do if they saw the chance to seize power themselves left the SPD with the uneasy feeling that the KPD offered almost as much of a trap as the activity of the NSDAP. Besides this worry, the SPD/ Reichsbanner leaders were confident that any confrontation would become an elementary lesson in numbers. The Reichsbanner outnumbered the SA by at least six to one. only the introduction of numerous weapons into the SA ranks would sway the balance. This overwhelming balance in favor of the Reichsbanner/Iron Front allowed walke to accept the KPD offer of a unified front only conditional$1 y$.

Reaction among Pfurigstadt's Jewish citizens was almost uniform. They were scared for their futures which seemed to be very insecure. Many wanted to leave Germany; a few prepared to do so. 19

Hitler's appointment to the chancellorship of Germany was accompanied by the announcement that yet another 
Reichstag election would be held--this time on March 5 . The SPD set out almost immediately to prepare for the election and begin to influence the voters. The first response was to the announcement of Hitler's becoming the German chancellor. On February 1 the Iron Front marched through the streets to the Rathaus where Fritz Dächert (Eberstadt) gave a short speech. 20 The next meeting set the tone for the entire election and served to clarify the position of the SPD regarding cooperation with the KPD. At the Iron Front meeting of February 10 Karl Pringsheim set down SPD policy. Organization of a Unity Front would proceed at the local level only because of the critical political situation. He reassured the members in attendance that socialism would triumph when he declared "We are now seeing in Germany the last actions of a critically old and sick capitalistic system which is falling to pieces because of its inherent contradictions. A socialist ordered economic system will take its place." He warned that preparation for action against the NSDAP did not mean wild and disordered thrusts against the Nazis, but a hard struggle through the election campaign. He closed by saying that "we are ready to fight:"21 The Reichsbanner/Izon Front had demonstrated its determination 
not to be cowed by the SA earlier in the week when they marched through the nearby farming communities (which were strongly pro-NSDAP). When the marchers returned to Pfungstadt another strong dose of encouragement was given to them by a leading Reichsbanner figure. This was followed on February 19 by a coordinated march of all Reichsbanner units in Kreis Darmstadt. 22

As the election neared the pressure upon the SPD mounted higher and higher. SA men boldly hooted and hollered at SPD meetings, an unheard of event. The newspaper publisher was reluctant to print SPD advertisements in the Anzeiger so the SPD worked day and night to print and distribute leaflets saying, "Whoever votes for Hitler is voting for war!" The SA had become bold enough to tear these placards down as fast as they were put up which led to numerous fights. 23 SPD members became edgy as the election drew closer. No one knew what was going to happen; it was like a leap into the unknown, only with men's lives at stake. The minister of finance, Korell, saw the overwhelming sentiment of the middle class for order, so that at the Iron Front meeting on February 24 he appealed to the bürgerlich to vote SPD stressing the "deutschness" of the workers. Pringsheim returned to lend a word of 
warning to the Nazis that they could expect massive worker action if they tried to seize the government by force. 24 Events were moving faster than anyone had anticipated. While the SPD/KPD felt that they could effectively repulse any NSDAP move in Pfungstadt the seat of their power was being jerked from beneath them. On February 13 the Anzeiger announced that a representative from the Reich Interior Minister had been sent to Hessen to "try to give the 'national right' the same feeling of protection as the 'left' enjoyed." Just four days later the Anzeiger carried a small announcement that Hessen's interior minister, Leuschner, would leave his post for a job in the International Trade Union office in Geneva on April.1.25 These articles made little impact on the working class of Pfungstadt at the time, but news they contained was to shape the fate of everyone in Pfungstadt for the next twelve years.

KPD members, who had had some instruction in the use of firearms openly boasted that Nazism would never assume power in peungstadt. The Kro was put into a delicate position by the entrance of Hitler into the inner sanctuaries of national power. They realized that they would be too small a group to resist Nazi encroachments 
if it came to an armed struggle. They did not have many guns, despite the rumors to the contrary, nor did they have much of a chance to secure them. In the place of weapons they offered manpower, manpower enough to see that their election material was distributed and that the NSDAP placards were tom from walls in pfungstadt and in many of the villages which surrounded Pfungstadt. Night after night the KPD was under way to confront SA men on similar tasks. ${ }^{26}$ Fear had not grasped them by the throat, but they were unfamiliar with the road they were following. They had never prepared for the possibility that they would have to stare at a Pfungstadt controlled by the Nazis. The time was too short for them to prepare an alternative course of action, therefore they pleaded with the SPD to join forces. It seemed the only logical course of action. Aside from the constant activity of the SPD and the KPD, the NSDAP was the only party to actively campaign for the Reichstag election. The old middle class parties staged no electoral meetings; only the DNVP had the strength to place one advertisement in the Anzeiger. The other old middle class parties despondently left the major campaigning to the NSDAP. The NSDAP began its campaign to convince the people of Pfungstadt that they were the ruling 
party on February 3. The Kreisleiter zürtz (Darmstadt) was invited to address the crowd and spell out the aims of the NSDAP since Hitler had assumed the chancellorship. A new energy had filled the ranks of the NSDAP since it had been announced that Hitler was in charge of the government. 27 This fact had been demonstrated in SPD meetings when SA men had boldly objected to the speaker's words. It continued in the NSDAP meetings themselves. When the Associated Union chairman. Peter Crößmann attempted to speak in the February 3 meeting he was bluntly told to "shut up" or face the consequences. 28 January 30 had put a new face on the NSDAF.

The main theme of the NSDAP during the election campaign was that work would be provided everyone once order was restored. No unusual activities were planned by the party since they thought that they had a very good chance to win the election without special outside help. Indeed, besides posting handbills, tearing opponents handbills down, suffering and giving a certain amount of physical pain, the campaign resembled, on the surface, any other they had staged over the preceding years. Included in NSDAP events was participation in a mass Nazi march in Darmstadt on February 6 and the introduction of the 
Nacional sozialistische Kampfbühne Gießen into the campaign on February 19. The Nazi actors presented the play, "Only then will Germany be free," to a large audience. 29 The presentation was in response to the SPD's "Roten Spatzen" which had increased its activity in relationship to the amount of Nazi propaganda which filled the town. Although the NSDAP play did not contain the same high quality work as the SPD's group constantly presented. It was, though, a boost to the morale of the local Nazis who faced the election with some drawbacks, since they did not have the manpower to take over Pfungstadt even if they had wanted to. The sensitivity of the normal middle class citizen was not shaken by the introduction of Hitler into the highest circles of the nation. The general feeling dictated that the prudent man wait and see how things developed. There was fear among many people that the Nazis would not be able to hold onto the power that they would claim after the election, since the SPD/KPD did not seem willing to give up without a fight. Therefore, a wait of several weeks would not hurt the image of the middle class citizen. Reenforcing the desire of most people to hold one card in reserve was the statement of several communists who boasted that when the Nazis failed, then the time 
would be ripe for the KPD to assume power. 30

The majority of the middie class saw the March 5

Reichstag election as a chance to decide between communism and the NSDAP. On such a basis the NSDAP was assured of receiving a solid number of middle class votes in their total, plus any working class votes of those who felt further struggle against the Nazis was useless. Hitler's reassuring words on the radio on February 10 and February 23 did not succeed in dispelling the notion that the NSDAP would bring only the best to the people of Pfungstadt. 31 Thus the middle class marched happily into the lion's den unaware that they were committing themselves to twelve years of dictatorship. By and large, the average middle class voter was completely unaware of the consequences his vote might have. They lived in a dream world of illusions and promises, following the pied-piper of destruction as if they were children. Part of the reason this could take place has to do with the nature of the NSDAP in Pfungstadt. Outside of a dozen hard core fanatics who would have kilied for any excuse, the body of the party was made up of men with accepted moral principles and normal aspirations. Some were idealists who truly believed that only the NSDAP could supply them with an answer to 
the years of hardship the town had had to endure. Others were pragmatic opportunists who felt that only Nazism offered an alternative to the KPD. Yet others sincerely believed that they had to accommodate themselves to the facts. All in all, they singularly failed to present the image of a group of men who would begin wars and murder innocent citizens. No one saw the truth. The most obvious reason for this vast breakdown of common sense had to do with ingrained prejudices which almost every middle class child had learned from birth. The "stink" of prejudice and blind hatred hung over many a grown middle class citizen because his father had instilled in him the seeds of wrath. The maturity of the men in question seems to have not been a positive factor. More than likely it gave them the knowledge and hatred to destroy their foes, the socialists. The utter lack of responsibility which the middle class citizen exercised in regard to the workers was almost pathological. A few middle class citizens had extended their hands in friendship to the SPD; the old bürgerlich publisher of the Anzeiger was a secret member of the party, and found understanding and thoughtfulness. 32 The majority would not. The utter, unreasonable contempt of the majority of the middle class, the 
fearful effects of the depression upon the financial security of many bürgerlich, plus the honey-sweet promises of an action-orientated NSDAP, combined to seal the the fate of a town that deserved a better fate. The very soil that produced a man of Wilhelm Büchner's stature and wisdom almost one hundred years earlier had lost an understanding for his principles. There were few tears shed for the withered dream of liberalism. 


$$
\text { CHAPTER XI - FOOTNOTES }
$$

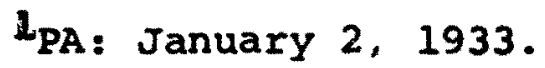

${ }^{2} \mathrm{PA}$ : January 2, 7, 9 and 10, 1933 .

${ }^{3} \mathrm{PA}$ : January 4 and 16, 1933 and notes from the file of August Hechler.

${ }^{4} \mathrm{PA}$ : January 6 and 21, 1933.

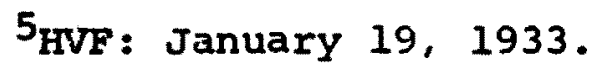

${ }^{6}$ Interviews with Karl Emig, Julius Winkler and Georg Liebig.

7Interviews with Jacob Delp and Georg Herth.

8 Notes from the private file of Heinrich Huxhorn.

${ }^{9} \mathrm{PA}$ : January 25, 1933 and HVF : January 26, 1933.

${ }^{10}$ Interviews with Jacob Delp, Karl Emig and Johann Kölsch.

$11_{\mathrm{PA}}$ : January 6 and 17, 1933.

${ }^{12} \mathrm{PA}$ : January 4, 1933.

$13 \mathrm{PA}$ : January $17,1933$.

${ }^{14}$ Interviews with Heinrich sand, Wilhelm Kaffenberger and Julius Hofmann.

${ }^{15} \mathrm{PA}$ : January 30 and 31,1933 ; notes from the file of Hans Oito: interviews with Jacob Hanbuch, Heinrich Sand and Karl Emig.

${ }^{16}$ Interviews with Georg Liebig and Peter crößmann. 
17 Notes from the file of Heinrich Huxhorn and interviews with August Hechler and Georg Herth.

${ }^{18}$ Interviews with Georg Herth, Jacob Delp, Pecter crößnann and Georg Liebig.

${ }^{19}$ Interviews with Julius Winkler, Maria Schulz and Karl Emig.

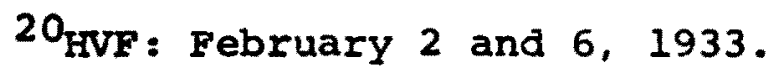

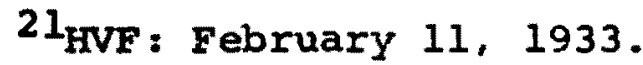

22 HVF : February 19 and 20, 1933.

${ }^{23}$ Interviews with Georg Liebig and Maria Schulz.

${ }^{24} \mathrm{HVF}$ : February 27, 1933 and interviews with Julius winkler and Peter Crößmann.

${ }^{25} \mathrm{PA}$ : February 13 and $17,1933$.

26 Notes from the file of Heinrich Huxhorn and interview with Jacob Delp.

${ }^{27}$ PA: February 2, 1933 and interviews with Heinrich Schaffiner and Jacob Hanbuch.

${ }^{28}$ Interview with Peter Crößmann.

${ }^{29} \mathrm{PA}$ : February 17, 1933.

${ }^{30}$ Interviews with Ludwig Gunkel and Jacob Brauer.

${ }^{31} 1_{\mathrm{PA}}$ : February 10 and $23,1933$.

${ }^{32}$ Interview with Gottfried Helene. 


\section{CHAPTER XII}

\section{THE NAZI SEIZURE OF POWER - MARCH, 1933}

Like a highpowered rifle, the March 5 Reichstag election was aimed at the heart of Pfungstadt's body politics. Whereas the first part of the election campaign had not differed markedly from previous campaigns, the last week of the struggle for votes compressed in a vice-like manner the problems of three years of depression into an explosive mixture of hatred and fear. Ready to detonate this dangerous brew was the news that the Reichstag had burned to the ground on February 27. Most people greeted the news with a silent shake of the head. Nazis and Nazi sympathizers leaned to the idea that the KPD had been responsible for the fire, although few thought that it had been a signal for a general KPD uprising, since, as one farmer said, "Berlin was too far away from Pfungstadt for me to worry about what happened there." I This same thought permeated much of the middle class. More cautious observers were simply confused. They did not know what to think. The SPD and especially the KPD labeled the Nazi 
charges that it had been caused by the KPD, a complete falsehood. Most KPD/SPD members thought that it was another of Hitler's tricks. But the most basic reaction of the KPD was one of discouragement and worry. ${ }^{2}$ If Hitler was willing to sacrifice the Reichstag building to gain his goal, they reasoned, what must he have in mind for them? The major effect of the burning of the Reichstag was to spur the Hessen government into banning all KPD publications and forbidding the KPD to stage election meetings. 3 In Pfungstadt the KPD went about their business without hinderence, but the members knew that their position in the community was becoming untenable. 4 A bold face could not hide the misgivings that individual members barely concealed from one another and the general public.

A more meaningful political occurrence for the people of Pfungstadt occurred in the not-to-distant Hessen town of Lindenfels (odenwald). After a morning filled with political parades and speeches, several young Hitler Jugend members had taken it upon themselves to remove opposition party flags from the working class district of Lindenfels. As a small group of HJ tried to tear down a Reichsbanner flag from the home of a worker, the young 
Pfungstädter Christian Crößmann, a HJ member was stabbed repeatedly by the offended owner of the flag. A Reichsbanner man was shot in the face during the wild melee which followed. 5 Cröpmann's violent death provided the perfect vehicle for the NSDAP to cap its increasingly belligerent campaign. On March 2 uncountable numbers of NSDAP and SA members and curious onlookers flooded into Pfungstadt to observe CröBmann's funeral. Calling on "all of the nationally inclined people of Pfungstadt to dutifuz ly attend his burial" the Nazis proceeded to turn the occasion into a massive display of NSDAP might. ${ }^{6}$ Thousands of Nazi people lined the streets as the body of crößmann passed in procession. The schupo set up a command post in Pfungstadt and deployed an enormous number of its forces in order to prevent trouble. The KPD and SPD people generally expected some sort of retribution to be dealt out by the Nazis, so they stood ready at various locations throughout the town. But the 3:00 P.M. funeral did not spark the tension filled atmosphere off. The burial of Christian Crößmann took place without incident. 7 More than the Reichstag fire the death and burial of crößmann proved to be the decisive event before March 5. 
The normally restrained middle class hurled charges of "red murderers" indiscriminately at the SPD and the KPD. 8 Everyone seemed to have been sorry that he had to die, but blame was generally affixed to the "reds" more and more. The SPD tried to defend itself by claiming that crößmann should not have invaded the private property of the Reichsbanner man, but the tidal wave of recriminatory remarks did not let up. The NSDAP call for the restoration of order struck the middle class as representing the most logical alternative in the frenzied days before the election.

The SPD/Iron Front attempted to set their own campaign in motion again on March 3 , but met the determined opposition of the Kreisamt when they scheduled a march through the streets before the gathering. ${ }^{9}$ Anndt (hìisbaden) reminded the SPD membership that order had to prevail within the ranks of the party if they were to remain an effective force. Many KPD sympathizers attended the SPD meeting seeking to bolster the determination of the working class to resist any Nazi seizure of power. But many people felt that the best tactic would be to let the NSDAP into power so that everyone might see that they couldn't do anything differently, 10 The leadership of 
the SPD did not endorse such thoughts, but a strong trend favored this approach. That was the last formal meeting of the SPD to take place for twelve years. Both the KPD and the SPD relief upon the distribution of handbills to fortify their supporters' determination to go to the polls. Several confrontations involving the NSDAP and KPD/SPD OCcurred over who would control the most advertisement space on the walls around the town during the days before the election. 11 Many people wanted to settle the issue of control even before the votes were cast.

The NSDAP encouraged its still small (in comparison to the SPD and KPD) membership to spread the Nazi word among prospective supporters. Added to that effort was one final act the night before the election--a parade. Whereas the SPD parade of March 3 had been banned, the Nazis took to the streets on March 4 to hear one of their leaders deliver some last words of encouragement. Again the police miraculously kept the peace between the warring factions. 12 The campaign would close without a major fight taking place in Pfungstadt. The Nazis openly boasted that they would achieve enough support to clean up Germany on March 5. In comparison to the KPD and SPD who went into the election grimly determined to hold their 
own, the NSDAP expected to be swept into power. 13 The confusing web of economic stagnation, political and social prejudices, ideological one-sidedness, and self-righteous (self-serving) indignation had altered the town of Pfungstadt fundamentally. Gone were the days of mild disagreements over day to day affairs; Pfungstadt stood face to face with its fate on March 5.

Four thousand nine hundred and thirty-one people, the largest number ever to take part in an election in Pfungstadt, went to the polls on March 5. This represented $95.5 \%$ of the eligible voters in pfungstadt. The results of the election were:

RESULTS OF THE MARCH 5, 1933, REICHSTAF ELECTION ${ }^{14}$

$\begin{array}{lllll}\text { KPD } & 1,026 & (1,148) * & 21.03 \% & (23.67 \%) \\ \text { SPD } & 1,427 & (1,446) & 29.25 \% & (29.81 \%) \\ \text { NSDAP } & 2,231 & (2,049) & 45.74 \% & (42.24 \%) \\ \text { OTHERS } & 2,231 & (2,049) & 45.74 \% & (42.24 \%)\end{array}$

The NSDAP had triumphed, picking up almost two hundred votes in the election, but had not achieved the magic fifty percent figure they had anticipated. The SPD and the KPD still controlled two thousand four hundred and 
fifty-three votes $(50.29 \%$ of the vote). The obvious loser of the election was the KPD which saw over one hundred and twenty of its supporters wander into other parties. The SPD dropped only nineteen votes, continuing to prove that its support was solid. But matters of majorities and pluralities in Pfungstadt became unimportant as the national returns had provided the NSDAP/DNVP with the required fifty percent to rule. The Nazis were prepared to set their rush to power into motion. Pfungstadt prepared for the Nazi "revolution:"

Amid the shouts of joy which surrounded the news of the results of the election late on March 5 among the ranks of the NSDAP was the knowledge that the SPD (and KPD) had vowed to fight any Nazi takeover in Pfungstadt. Heinrich Huxhorn addressed a gathering of KPD men and women the night of the vote while in the streets Iron Front/KPD patrols watched for any sign of the Nazis. 15 Patrols were particularly heavy in the working class section of Pfungstadt. The KPD also put out a special edition handbili proclaiming, "Hitier, the strawman of the capitalists."16 While the SPD/KPD members mingled on the street and at previously arranged strategic points throughout Pfungstadt (as on January 30 ), the leaders of 
the KPD and SPD were meeting. 17 Everyone waited for the expected Nazi blow. The NSDAP itself was waiting for word from its own higher authorities on how to proceed. 18 Many prople spent the night of March 5/6 awaiting any development. Nothing happened.

The failure of the NSDAP to move during the night did not indicate a lack of resolution on their part, for early on the morning of March 6 word that the Nazis had occupied the Rathaus and hoisted the swastika flag--this news flashed through the working class. Other strategic installations were not occupied by the Nazis. Just as quickly as word was received the workers of $\mathrm{P}$ fungstadt rushed to the town hall to view the development for themselves and to take counter measures. 19 The working class was not prepared to give up Pfungstadt without a fight. Hundreds of working class people, men and women, surrounded the Rathaus within twenty minutes. After a brief discussion the SPD/KPD leaders presented the occupiers with an ultimatum to either remove themselves and their flag or face the wrath of the workers. Slowly the minutes ticked by; the tension mounted. Word came back from the occupiers that the flag would only be taken down "over their dead bodies." But outnumbered by at least one 
hundred to one, the occupiers had little prospect of holding their position in the Rathaus. Commands were shouted, the crowd surged forward and within a few short minutes the occupiers were no longer in control of the town hall. Almost solemnly the Nazi swastika flag was lowered to the ground where it was burned amid general jubilation. 20 The workers of Pfungstadt had stood their first test.

Shortly after the Nazis were routed from the town hall the KPD and Iron Front leadership met to assess the situation. Huxhorn demanded that the workers occupy the town hall themselves while Albert wälke put off a decision until he received instruction "from above."21 Nevertheless the workers controlled the streets of Pfungstadt. Large masses of people milled about everywhere, speaking in excited tones of the morning's events, and pledging their determination to defend the town against the Nazis. Frantically the SPD/Iron Front attempted to establish and maintain contact with higher officials in Darmstadt, above all with the Interior minister, Leuschner, upon whom they were depending to lead the charge against the Nazis. Comnunications with the Interior minister and other SPD officials was on again, off again, throughout the day. News that the Nazis had occupied the offices of 
the Interior minister reached Pfungstadt in the afternoon?22 If the town of Pfungstadt was to defend itself against a Nazi take-over it would have to do it by itself. The Iron Front plan to place themselves at the service of Leuschner as reserve police was shattered by the news that Leuschner had apparently given in without a fight. Minister-president Adelung's power along with the last vestiges of democratic freedom were buried together with the chances of Pfungstadt to survive for very long. This fact was not lost on the leadership of the KPD or the SPD. Although the workers controlled the streets and therefore the town on March 6, they could not expect to retain their hold if the Nazis had control of the Interfor ministry and with it the guns the democrats of pfungstadt had expected to employ against the Nazis... Now, ironically, those same guns would end up in the hands of the Nazis, to be used against the workers of Pfungstadt if they continued to object to the Nazi takeover. Throughout March 6 the leaders of the SPD remained convinced that their state leaders would soon order a move against the NSDAP. ${ }^{23}$ Even after word that the state police had turned over their guns to the Nazis in the courtyard of the Hessen Interior ministry the leaders 
continued to hope. Leuschner, they argued, was still in control of the situation no matter how things looked. He would soon send word. An uneasy calm settled over Pfungstadt as the evening spread. Taking all precautions the KPD leadership and the SPD/Iron Front leadership met for one final time in the forest near Pfungstadt late in the evening to await news from a special messenger they had sent to Leuschner. The messenger returned in tears with the sad message that no resistance to the Nazis would be offered by the higher authorities. ${ }^{24}$ The men who were prepared to fight would have to be sent home. Nazism would triumph over an inert leadership, over a negative action. The implication of the sorrowful tidings was not lost on the KPD/SPD leaders. They realized that the end of the Weimar Republic in Pfungstadt was at hand. A local resistance movement might prove an interesting footnote in some future history book, but would not aiter the fact that the NSDAP controlled the state government and with it the weapons the SPD had counted upon. 25 There was nothing more to be done. Some of the leaders returned to their homes; others, including Huxhorn set out to escape the arrest warrants that they had been informed awaited them in Pfungstadt. 26 Pfungstadt was handed to the 
Nazis by circumstances which were out of the hands of the local leaders.

Confusion had been the order of the day within the NSDAP's ranks after the workers had torn down the swastika flag from the town hall. Throughout the day the SA and NSDAP nembers feared to go into the streets. 27 The leaders of the NSDAP nervously awaited a message from their higher authorities in Darmstadt as to how they should proceed. Word had been given to raise the swastika flag on the town hall again but it was not heeded. 28 Throughout the day conferences and meetings of the NSDAP leaders were carried on. Late into the night they planned their next step. It was to be a giant step for the NSDAP; a step from relative powerlessness to complete control--from the shadows to the center of the stage. Early on the morning of March 7 the second attempt of the NSDAP to seize power begar in Pfungstadt. This time the SA was armed and reenforced by SA from Darmstadt and by local farmers who were pressed into service at the insistance of ortsqruppenleiter Gräf. Where the fiery words of the workers had once promised stiff opposition to the NSDAP on the day before, now roamed armed bands of men on patrol. Through the streets they went warning inquisitive onlookers to shut 
their windows and to remain indoors. Several SPD and KPD people who ventured into the streets were beaten on the spot, while one KPD man who defied the new authorities too vigorously was shot in the leg. 29 New masters had come to pfungstadt and they were determined to assert their authority in no uncertain terms.

Members of the Nazi patrols were on the alert to an anticipated KPD/SPD counter attack. When it did not come many concluded that the majority of the people wanted order, not the "marxist" leaders. 30 Little did they know that the SPD only stood back from active opposition at the eleventh hour at the insistence of the state party leaders. But that did not matter to the SA and NSDAP. They now controlled the streets. They now commanded the public order. The town hall was re-occupied, the flag of the Republic burned, and the police evicted from their headquarters. A curfew was also put into effect. All busi-. nesses had to close by 8:00 P.M. and all the inhabitants of Pfungstadt had to clear the streets by 8:30 P.M. 31 The NSDAP indecision of March 6 had been replaced by a firm resolve to seize power in Pfungstadt on March 7 . Physical hindrance to the Nazis was no longer organized or effective. 
Primarily responsible for the lack of organized opposition were the police searches of homes which began sporadically on March 7 and swung into full force on March 8. Ostensively the police and SA Hilfspolizei were looking for guns. In reality they intimidated SPD and KPD people while they collected all of the KPD and SPD records, typewriters, and hand printing presses. ${ }^{32}$ some people were taken to the town hall for interrogation, others were ordered not to leave their homes. The middle class enthusiastically greeted the stringent measures of the NSDAP. "We felt relieved," was the way one farmer put it. 33 others spoke of the streets being "clean" again. The middle alass looked forward to better times. Besides the Nazi show of strength in Pfungstadt the old democratic government of Hesse-Darmstadt played a role in holding the working class in line. On March 9 the government announced that: "The transfer of police power to the (NSDAP) Commissioner, Dr. Müller, does not indicate that other governmental functions have been redelegated. The government of Adelung-Krinberger is still in charge and at their posts." 34 This notice had a profound effect upon Pfungstadt. The SA even felt secure enough to call off the curfew although it restricted groups of people 
to less than three at one time and ordered special watches in the working class section of town. 25 The job of the SA Hilfspolizei was made easier by several turncoats from among the KPD and SPD. A number of SPD and KPD members turned over information to the SA which was instrumental in revealing the location of secret hand printing presses wich had been employed duxing the Reichstag campaign and in the days after March 5 . Some even pointed out the hiding places of their former leaders. ${ }^{36}$ peter Crößmann fled to the odenwald where he hid for six weeks hoping to finally make his way to Switzerland. He returned for his wife who had to bear the brunt of repeated SA searches in his absence. Only the recent birth of a son prevented them from making the trip. He finally returned to Pfungstadt in April and was promptly arrested. Huxhorn got as far as Mannheim before he was captured and returned to Pfungstadt under police guard. 37

on March 11 the national government gave the order for the arrest of all KPD and Reichsbanner leaders which led to the wholesale rounding up of men in Pfungstadt. Almost all were questioned at the town hall and released. A new pattern was emerging for the SPD and KPD members. They waited night after night for the SA to knock at their 
doors, to search their hories and sometimes take them in for questioning. But such actions did not stop the KPD and SAJ from printing handbills against the new "order" in Pfungstadt. Morning after morning the citizens of Pfungstadt awoke to find new evidence of opposition to the Nazis in their mailbcxes. ${ }^{38}$ An organized revolt against the NSDAP might not have been possible, but a resolve to launch anti-Nazi counter attacks had not been lost. The handbills were mere pin-pricks in terms of overall effectiveness although they made the local Nazis angrier on each successive day. One such handbill aimed at arousing resentment against the Hilfspolizei by claiming that they were costing the state an enormous amount of money. The NSDAP felt so threatened by this rumor that they published a special notice in the Anzeiger proclaiming that the Hilfspolizei were doing police work as "honorary" officials without pay.39 The situation in Pfungstadt was still fluid; the NSDAP had seized power, but it had not consolidated or legitimized it.

The first tentative step in rallying the people of Pfungstadt to the new government was taken on March 12. The day was set aside as a tribute to the fallen soldiers of World war I. A church service and memorial ceremony at 
cemetery were heavily attended by the middle class which no longer felt it needed to hide its NSDAP leanings. 40 The Nazis were considerably heartened by the response of the middle class inhabitarts of Pfungstadt. As soon as the workers had been deprived of the means of putting them under economic pressure, a large number applied for party membership. The party secretary, sand, had to work for hours processing names and addresses of the long dine of people which daily camped before the door to his home anxious to enroll in the party. 41 The mask of "non-political" politics fell from the faces of many people as soon as they felt the Nazis were securely in power. On March 14 the Hessischer Volksfreund was banned for five days (to March 19) and the ban was later extended until March 26.42 At the same time the SA demanded that all guns be turned in to the town hall. The results of the initial SA sweep through working class homes had been frightfully disappointing for the Nazis. They had expected to find a large number of guns, but they found only a half dozen. To rectify that apparent oversight the new order was issued. This also gave the SA the opportunity to re-examine any home they wished to. The people of Pfungstadt were ready to believe anything. The mother of 
one of the school teachers was accused of hiding a machine gun in the attic of her home because her son was a demo-: crat. ${ }^{43}$ Wild rumors floated about the streets telling of this or that person having stashed his arsenal in the forest or in his garden. The credulity of the people led to the strengthening of the NSDAP's hand vis-a-vis the SPD and KPD. Although a complete search of suspicious homes was made again and the time for turning in weapons was extended until March 21, the results of the SA determination to uncover guns was again poor. A number of crude homemade brass knuckles, billy clubs and other street-fighting gear was uncovered, but the anticipated cash of arms was never found (because it had never existed). 44

In quick succession the NSDAP staged several events designed to win over the uncommitted and to isolate the opposition. On Saturday March 18 all of the Pfungstadt's "nationally minded citizens" were urged to join in an NSDAP celebration in the yard of the school. Several speakers called the moment an historic one for Germany that left the way free for the rebuilding of a great German Reich. All of the citizens were urged to join in the work to be done. The easiest way for that to be done was to join the NSDAP said Wilhelm Martin.45 The cloak of 
impartiality which he had wrapped so tightly around himself in the years before 1933 was discarded publicly on March 18. The extent to which he had hidden his affiliation with the NSDAP was testified to by a KPD man who first realized Martin's political affiliation when he saw him in an SA uniform shortly after March 5. Other people who had been too timid to reveal their true allegiance before March 5 also shed their "non-political" cocoons after the Nazis were in control, among them Georg steinmetz. Many middle class people also attended the March 19 church services of thanks that Germany had avoided civil war and the dangers of communism. 46 The middle class moved quickly to adjust themselves to the reality of Nazi authority.

The opening of the Reichstag on March 21 provided another occasion for the Nazis to rally "all people who count themselves among the masses of national Germans" in Pfungstadt into the streets. 47 f parade began the events of the evening which included speeches in front of the town hall. Earlier in the day all businesses had been closed (from 10:00 A.M. to 3:00 P.M) to allow the population to listen to the opening of the Reichstag. Loudspeakers were set up in the streets so that no one could miss 
a thing. Besides the $S A$, the volunteer fire department members, the teachers from the school, postal workers, train and town officials, the Krieger- und Militărverein associates, the "German" sportsmen, singing clubs and other groups took part along with a large number of inhabitants who were not covered by one of the participating clubs. 48 The attention the Nazis paid to the inclusion of politically inactive associations was in marked difference to the situation as it had existed before March 5. 1933. The participation of the clubs added to the size of the crowd and undoubtedly brought individuals to the festivities who would otherwise not have participated. Besides it gave the middle class (all of the clubs participating were bürgerlich) the chance to feel that they were part of the ruling circle once again in pfungstadt. At the town hall the torches most of the parade's participants had carried were thrown into one large fire which impressively illuminated the front of the town hall and the eager faces of the crowd. The ortsgruppenleiter opened the festivities with a greeting for the assembled people and turned the main speaking duties over to Georg steinmetz. Steinmetz took the opportunity to thank the people of the NSDAP who had prepared the way for the :...- 
ascension of the Volkskanzeler Adolf Hitler. He then invited anyone who had not joined the party to do so, so that they might become a part of the rebirth of Germany. closing his speech with three sieg Heils, he introduced the Musikverein band which played the German national anthem, the Deutschlandlied. 49 Another small step had been taken toward total control of Pfungstadt by the Nazis.

No part of the citizens of Pfungstadt was overlooked by the Nazis after they had seized power. The first thrust had been by inclination toward the middle classes, the second was toward the workers. The main instrument at the disposal of the party for the assimilation of the workers was the SA. The means at the disposal of the party to enlist the support of the workers were many. There was direct physical threat (rarely used) and the more effective, indirect pressures which could be brought to bear upon men who in many cases had been without work for long periods of time since 1929/30. The propagation of the doctrines of the NSDA.P/SA took second place, at first, to the enrollment of the maximum number of workers in the shortest period of time. To that end the SA staged an assembly on March 31. The dissolution of the established organs of the workers was a direct assistance to the SA. The SA, 
for its part, encouraged the workers to believe that they were only replacing a set of worn out leaders with fresh faces who understood the wishes of the working class. But the emphasis of the SA was on replacing the class hatred of the "marxists" with class cooperation of Nazism.50 The SA theory often was overlooked by prospective members who joined simply to escape pressures to join the party itself. Others firmly believed that the dismal showing of their leaders on March $5 / 6 / 7$ really indicated that the days of the SPD/KPD were over. 51 In any event the response of the workers to the call of the sA to join in Nazis Volksqemeinschaft was respectable. Few workers rushed into the arms of the Nazis, but few could escape its growing influence in all sectors of the life of Pfungstadt. The NSDAP march to power was not slowed by the working class once the issue of the town's control had been decided. The issues at stake in Pfungstadt between 1928 and 1933 were often complex, they were always formidable for the people involved with them. That the power to unravel the difficulties would shift so drastically in Pfungstadt between March 5 and March 8 was unforeseen by everyone, Nazi and non-Nazi alike. The opportunity for the SPD/KPD to retain their power had been handed to them by the 
enraged vitality of the workers on March 6 ; the decision of "higher authorities" not to oppose the encroachment of the Nazis into the seat of power in Hessen thwarted the pent-up energy of the local groups in Pfungstadt. There can be no doubt that the SPD/KPD would have fought (and most likely beaten) the Nazis if they had been given the signal to proceed. Unfortunately the decision was not made, which left the leaders of Pfungstadt's SPD and KPD free to involve themselves in a hopeless struggle against a Nazi party which would have called in reserves from other towns until the issue was resolved. The leaders instead had to admit that they were without the resources to prevail. Their numbers on the local level were sufficient; unhappily that was not the case either on the state or national level. 


\section{CHAPTER XII - FOOTNOTES}

Interview with Ludwig Gunkel.

${ }^{2}$ Interviews with Georg Herth and Jacob Delp.

${ }^{3} \mathrm{PA}: \operatorname{March} 2,1933$.

${ }^{4}$ Interviews with Georg Herth and Jacob Delp.

$5_{\mathrm{PA}}$ : March 27, 1933 and HVF: March 27, 1933,

${ }^{6}$ PA: March 1, 1933 and interviews with Jacob Hanbuch and wilhelm Kaffenberger.

${ }^{7} \mathrm{PA}:$ March 4, 1933 and March 3, 1933.

${ }^{8}$ Interview with Peter Crößmann.

${ }^{9}$ HVF : March 4, 1933.

${ }^{10}$ Interviews with Georg Liebig and Jacub Delp.

${ }^{11}$ Interviews with Heinrich Schaffner, Jacob Delp, Karl Emig and August Hechler.

$12 \mathrm{PA}$ : March 6, 1933.

${ }^{13}$ Interviews with Heinrich sand, Wilhelm Kaffenberger and Heinrich Schaffner.

${ }^{14} \mathrm{PA}$ : March 6, 1933.

15 Notes from the file of Heinrich Huxhorn and interviews with Jacob Delp and Georg Liebig.

${ }^{16}$ Interviews with Jacob Delp and Georg Herth. 
17Notes froin the file of Heinrich Huxhorn and interviews with August Hechler and Peter Crößmann.

${ }^{18}$ Interview with Heinrich Sand.

${ }^{19}$ Interviews with August Hechler, Johann Kölsch, Julius Winkler, Ludwig Wenz, Heinrich Schaffner and Jacob Hanbuch.

$20_{\mathrm{PA}}$ : March 6, 1933 and HVF: March 13, 1933.

${ }^{21}$ Interviews with Georg Herth and August Hechler.

${ }^{22} \mathrm{PA}$ : March 7, 1933 and interviews with Georg Liebig and Georg Herth.

23 Interviews with Johann kölsch, August Hechler, Georg Liebig and Peter Crößmann.

${ }^{24}$ Notes from the file of Heinrich Huxhorn and interviews with Georg Liebig, Georg Herth and Peter cröBmann.

${ }^{25}$ Interviews with August Hechler and Jacob Delp.

${ }^{26}$ Notes from the file of Heinrich Huxhorn.

27 Interviews with Heinrich sand and Jacob Hanbuch.

${ }^{28}$ Notes from the file of Heinrich Huxhorn.

${ }^{29} \mathrm{PA}$ : March 7, 1933 and interviews with Jacob Delp, Heinrich Schaffner, Maria Schulz, Ludwig Gunkel and Peter crößmann.

${ }^{30}$ Interviews with Heinrich Schaffner and Wilhelm Kaffenberger. 
${ }^{31} \mathrm{PA}:$ March 7, 1933.

32 HVF : March 11, 1933 and interviews with Jacob Delp, Johann Kölsch, Jacob Hanbuch and Heinrich sand.

${ }^{33}$ Interview with Ludwig Wenz.

${ }^{34} \mathrm{PA}$ : March 9, 1933.

${ }^{35} \mathrm{PA}:$ March 10, 1933.

${ }^{36}$ Interviews with Georg Herth, Jacob Delp, Peter Crößmann, Heinrich Sand, Jacob Hanbuch and Wilhelm Schaffner.

37

Notes from the file of Heinrich Huxhorn.

${ }^{38}$ Interviews with Maria Schulz, Julius winkler, Jacob Delp and Peter Crößmann.

${ }^{39} \mathrm{PA}:$ March 11, 1933.

$40_{\mathrm{PA}}$ : March 13, 1933.

${ }^{41}$ Interview with Heinrich sand.

42 HVF : March 14 and 19, 1933.

${ }^{43}$ Interview with Julius winkler.

${ }^{44}$ Interviews with Heinrich Schaffner and Wilhelm Kaffenberger.

${ }^{45} \mathrm{PA}:$ March 17 and $20,1933$.

${ }^{46} \mathrm{PA}$ : March 22, 1933.

${ }^{47} \mathrm{PA}: \operatorname{March} 21,1933$. 
${ }^{48} \mathrm{PA}:$ March 20 and $22,1933$.

${ }^{49} \mathrm{PA}:$ March 22, 1933.

50 PA: March 31, 1933.

${ }^{51}$ Interviews with Karl Emig, Johann Kölsch, Peter Cröpmann and August Hechler. 
CHAPTER XIII

LEARNING TO MARCH IN STEP - APRIL TO JULY, 1933

Seizing power was the first aim of the NSDAP in Pfungstadt; this had been accomplished by the bold stroke of sending both armed $S A$ men and farmers into the streets of the town. The "sensible" response of the SPD/KPD leaders to the fact that Leuschner would or could not supply them with the guns they needed to resist the Nazis had, in the first instance, decided the fate of Pfungstadt. The events of March had been decisive. The NSDAP's actions in the ensuing months were also important, if not dramatic, for the installation of Nazi authority in Pfungstadt. Once the Nazis had overcome their fear of the SPD/KPD they proceeded to install a vast array of party programs. The persecution of the Jews was one of the very first.

Late in March the first signs of overt anti-semitism surfaced in Pfungstadt. Mostly, the anti-Jewish actions were directed from sources outside Pfungstadt, but a small group of early Nazi beljevers spurred hatred 
hatred against the Jews from inside pfungstadt also. A few really hardened SA men stole wood from a Jewish lumber yard in broad daylight. Others went to Jews to whom they owed money and forced them to mark their bills paid. 1 This sort of despicable practice found little echo among wider circles of the population. Efforts to spread the terrible desease among the general populace failed. Even NSDAP members were to be found who did not approve of the robbery perpetrated upon the Jews. Several Nazis secretly paid their bills to Jews at night, while others went to the Jewish dentist in town despite the warning of their associates. 2 The farmers, always a stubborn band, continued to trade with Jews in spite of several threats. Nearly everyone agreed that "our Jews were alright."3 Thus the instigation of a boycott against the Jews came from outside of Pfungstadt. It is very likely that the ruling Nazi. leadership in Pfungstadt would never have been original enough to develop such an idea without the explicit instructions of their superiors. There simpiy was not enough "traditional" hatred of the Jews in Pfungstadt. The first signs of an impending boycott against Jewish-owned businesses came on March 28 when the Anzeiger carried an article decrying the "Jewish 
slanders of the German state."4 As in other parts of Germany this was the signal for the formation of a Nazi committee to "defend our country." The specific charge against the Jews was that they had inspired foreign propagandists to belittle Germany. Most of the citizens of Pfungstadt neither understood the merit of the charge nor the basis for it. But the Jewish inhabitants realized very well what was happening after they were forced to send a telegram to the British ambassador in Berlin stating that there had been no persecution of Jews in Pfungstadt. 5 Having been forced to send the telegram, the Jews expected something worse.

Saturday, April 1, 1933, was set aside by the national Nazi leaders as a day to boycott all Jewish businesses and other businesses who employed Jews. In Pfungstadt placards were posted on the windows of Jewish firms and SS men stationed before the entrances of each store controlled by a Jew. Each person who attempted to enter the store was then warned not to, and if he persisted and enteres his name was written down. On several occasions photographs were taken of people entering and leaving Jewish firms. ${ }^{6}$ The bürgerlich in Pfungstadt were particularly offensive on April 1 while the working class 
by and large continued to shop as they always had, partly in defiance of the Nazi order. ${ }^{7}$ Even the determined resistance of large numbers of working class citizens did not delude people into thinking that they would hold out against Nazi power if, indeed, the NSDAP wanted to close all of the Jewish shops in Pfungstadt. But outside of a minority of middle class Nazis, the people of pfungstadt did not adjust themselves to the new orders of the NSDAP. Indeed, the Nazis announced on April 5 that the boycott of Jewish business would not be repeated. 8

Failure to stir up the hatred against the Jews, they had predicted did not deter the Nazis from keeping pressure on the Jews. Only a small number of SA were needed to remind people that those who shopped at Jewish stores were not in accord with the new leaders of Germany. Over :the months the party effectively reminded people of their new obligations without resorting to heavy-handed physical pressure. Slowly the Jewish businesses closed their doors. ${ }^{9}$ The success of the Nazis was not widely welcomed.

officially the mayor and vice-mayor remained the chief arbiters of pfungstadt even after March 5 . In reality the Nazis and their Hilfspolizei ruled. Among the 
various measures pushed through by the NSDAP after it assumed power was the order for the removal of all SPD (and KPD) mayors and vice-mayors in Hesse-Darmstadt. 10 For ten days (from March 23) until April. 3 Pfungstadt was devoid of executive authorities. On April 3 the Kreisleitung of the NSDAP named a new mayor and vice-mayor for the town. Replacing Johannes Schwinn ${ }^{*}$ would be Georg Steinmetz and replacing Paul Weigel (SPD) would be Wilhelm Martin.11 The normal procedure for the Nazis was to appoint the ortsgruppenleiter to the position of mayor thus assuring him not only party control but also administrative control of the town under his jurisdiction. In the case of Pfungstadt several factors merged to produce a different outcome. Ortsqruppenleiter Gräff was judged not to possess the requisites and abilities needed for the job, and Steinmetz and Martin had built a solid reputation among the middle class. Those who were involved in advising the Kreisleitung about replacements for Schwinn and Weigel almost to a man recommended Steinmetz and Martin over Gräff!2 Besides, steinmetz and Martin had earned the respect of the

*schwinn did not belong to any party, a fact which few people, even SPD members, knew. He was dismissed because he had constantly sided with the SPD in the council. 
privileged few who knew of their pre-1933 membership in the NSDAP which was evidenced by their appointments to the Kreistag.: The choice was natural considering the NDSAP ties of Steinmetz and Martin and the following they had molded together in Pfungstadt before 1933. Indeed they might very well have provided a solid obstacle to the Nazis if they had not been included in the new government of Pfungstadt. The bürgerlich of Pfungstadt greeted the news of Steinmetz and Martin's appointments with approval and even the working class acknowledged that the two men were highly intelligent, even if somewhat egotistical. 14 In addition to a new mayor and vice-mayor for $P$ fungstadt the town laws of Hesse-Darmstadt were altered after March 5 so that the town council would be composed of only fifteen members. (Before March 5 there had been twenty members of the town council.) To effect the change in the town council a committee was established by the NSDAP on April 21. 15 The job of the committee was to approve a list of candidates submitted by the parties still eligible to participate in the work of the council. (In the case of Pfungstadt this was only the NSDAP and the SPD; the KPD had been banned.) The NSDAP would hold nine seats (plus the two of Steinmetz and Martin) while the SPD was 
limited to six places on the council. The SPD decided to submit a list of names despite warnings from various sources of the consequenses they could expect. August Hechler, as the chairman of the party, submitted the names to the newly installed Mayor, Steinmetz. As Hechler entered the room in the old town hall, official Buchholz waved his arms wildly for Hechler to stop. He just had time to whisper to Hechler, "Why do you want to risk more trouble?"16 Resolutely Hechler read the names to Mayor steinmetz, knowing that Buchholz's words boded ill for the men involved. On April 24 the town council met to approve the lists of town council members which had been introduced previous..y. The SPD would be represented by old established names: Ernst wälke (brother of the Reichsbanner leader, Albert), Michael Hechler (a long-time member of the council), August Hechler (no relation to Michael Hechler, and chairman of the SPD for two years), Ludwig clemenz (second in command to Albert wälke in the Reichsbanner), Georg Schulz (a long-time member of the council) and Albert Stock (another long-time member of the counci1). The NSDAP produced a list of people who were chiefly noted for their NSDAP membership, not for their town council experience. Included were: Georg 
Riehl (an associate of steinmetz and Martin in the now defunct party of Steinmetz-Martin), Wilhelm Gräff (ortsgruppenleiter and four-year memper of the council), Karl Polster (a high official in the local SA), Heinrich May and Ludwig Cröpmann (both farmers and leaders of the drive to bring farmers into the party), Jacob polster (activity unknown), wilhelm Kaffenberger (early member of the SA and NSDAP, and Hans otto (first member of the NSDAP in Pfungstadt). 17 The meeting was closed.

on May 8 the "new" council met for the first time. Steinnetz opened the first official session by announcing that the work of the council would be done totally by committees. He then delegated a seat on the various committees to each of the NSDAP members of the council. The SPD was systematically excluded from each committee. They were also excluded from voting on the change in street names which the Nazis demanded. The Bahnhofstraße was renamed the Heinrich-Kottmann-Straße; the Waldstraße acquired the name the straße der $\mathrm{SA}_{\text {; }}$ the Lindenstraße received the name fdolf-Hitler-straße, and the seeheimer-straße was renamed the Christian-Cröß-mannstraße. ${ }^{18}$ The changes of names did not strike at the heart of the political system the way that the exclusion of the SPD from the committees 
of the town council did. As the meeting reached an end any notion the SPD town council members might have had as to their remaining in the council was dispelled when Albert Stock and August Hechler were given written notice that they would not be eligible to continue in their posts because they had been members of the SAJ's Rote Spatzen. This NSDAP manouver drove the entire group of SRD people to tender their resignations in unison. 19 There was to be no accommodation with the NSDAP in Pfungstadt. At a meeting of the town council later in May the problems of money and the unemployed reared their ugly heads once again. Financial and social difficulties did not respect the change in the government. The new administration of Pfungstadt moved into the field of unemployment with a tougher approach to the problem than had previously been the case. On April 22 the town administration handed down the order that no unemployed person would be able to receive his payment if he did not sign up for the work service. 20 To the seven hundred and twenty-six unemployed who depended upon the town to supply them with the barest necessities of life, this did not come as good news. And unless the town had in mind to employ the men in some meaningless sort of work, the 
gathering together of the unemployed could constitute a real burden for the town budget in that supplies would necessarily have to be purchased before the unemployed could begin to build or repair anything. The old fears of the bürgerlich were indeed aroused by the thought that they might possibly have to provide tools or supplies before constructive jobs could be found for the unemployed. At the May 18 council meeting the NSDAP decided to reject a fifty-six thousand mark loan that they were offered to introduce new projects for the jobless. 21 The function of government in Pfungstadt after March, 1933, did not seem to have been improved in the slightest after that quick bit of hide-and-sıek had been played at the expense of the unemployed. Leadership ability had not gained from the change in the government. The reordering of the political system did change the role of the NSDAP in Pfungstadt. Whereas less than one hundred people had been associated with the party before March, 1933, after that time people had begged to get into the party. The swelled rules of the NSDAP meant that the close association that had been the trademark of the early members would be lost. Also, the party gained many "pragmatic" citizens who knew little or nothing of 
the aims of the party. This threatened to dissolve the ideological purity of the party into a very weak brew. To counter the influx of "uneducated" comrades into the party, the leaders of the NSDAP instituted a series of Schulungskurse (political education meetings). On April 24 the NSDAP held its first meeting "to give the people a chance to learn about the NSDAP." Attendance was mandatory.22 The second Schulungskurse on May 8 was concerned primarily with "National Socialism and the German woman." 23 on June 8 the Nazis scheduled yet another political education meeting concerning "The lies of the marxists." In his speech Dr. Schmidt blamed the "marxists" for the disorder which occurred in the time of the Weimar republic, the defeat of Germany in the First world War, and the power of the Jews. 24 The Schulungskurse scheduled for May 22 was replaced by another mandatory NSDAP members' meeting. At the meeting the mayor (Steinmetz) was vested with the responsibility for all town policies. This, the speaker claimed, would allow for the quicker integration of the town into the Nazi system of government. 25

Against the darkening sky of political dictatorship the Nazis attempted to gather any bürgerlich behind 
the new government. To further the aims of the Nazis, all non-party bürgerlich were urged to join the Kampfound für den gewerbliche Mittelstand, League of middle class businessmen. 26 Dr. Schmidt (Kreispropagandaleiter and leader of the schulungskurse) was the first representative of the NSDAP to greet the assembled bürgerlich businessmen on April 1 at the first meeting. Claiming that the entire Handwerker and tradesmen of Pfungstadt had to work together to help the new state, Schmidt confirmed the apprehensions of some when he notified the people present that association with the group would be mandatory for the businessmen of pfungstadt. Several businessmen joined the new group in the weeks that preceded its second meeting on April 22 simply to avoid the pressure that had been applied to them to join the NSDAP. 27 If anyone thought that the Kampfound would not become the tool of the Nazis he was rudely shocked to find that by the middle of May the Handwerker- und Gewerbeverein was also urging its members to attend the joint NSDAP-KampFound meeting. 28 NSDAP member Ludwig stetter opened the meeting as the chairman of the Kampfound. He warned that while many bürcerligh felt that marxism was now dead, that really was not true. The marxists only appeared to be dead--in 
reality they were continuing their program of stimulation of class hatred. If the middle class did not throw off its politically disasterous ways, then, he warned, the marxists might yet cause Pfungstadt's citizens much trouble. A brief review of German history with a NSDAP twist proceeded the call of ortsgruppenleiter Gräff for all of the assembled businessmen to join the NSDA.P in order to save Germany.29 The tactics of the Nazis were twofold: 1), the Nazis desired that the greatest portion of the bürgerlich join the party, but, failing that, that they 2) associate thenselves with an organ of the middle class that stood in close contact with the NSDAP leadership. If direct belief in the ideology of the NSDAp would not do, then the Nazis were prepared to force the middle class to action by spurring their fear of the "marxists" (a word which meant not only the KPD but also the SPD). One way or another the Nazis would have their way. Pfungstadt's workers were not forgotten during the Nazis rush for total control. Having deprived the working class of their leaders through physical force (such as sending a number of KPD leaders to the proto-concentration camp osthofen) or by intimidation, 30 the Nazis moved to capture their support. 
Although the NSDAP party was the basic unit of the Nazis the must representative organization, in terms of variety of classes, was the SA. Within the SA were to be found the workers who shortly before had been the most bitter enemies of the Nazis. Few workers joined the party itself because the working class was not favorable to the Nazis. But the working class people were also pragmatic. Like many other people they realized that the Nazis would not allow them to remain outside of the Nazi system for long, and therefore many joined the SA in the belief that they would then not have to join the party itself. 31 For those that could not make up their minds, the Nazis decided to take action. After the Reichsbanner and Iron Front had been banned, the Nazis assembled the workers in the sportplatz and "enrolled" them in the SA 32 Direct physical pressure was not needed since it had become abundantly clear that anyone who was not a member of the SA would find it impossible to find work. This fact was pointed out at the factory before the operation took place. 33 More subtle methods were used on the bürgerlich. The SA staged a "display" of its various activities on April 9 at the town hall square. Mayor Steinmetz delivered a rousing dose of promises to the assembled crowd 
which was then able to ponder his thoughts to the music of the Musikverein. The gathering left for horne after several sieg Heils. 34

The extent of the Nazi success in organizing former Reichsbanner and KPD members, together with willing middle class citizens was soon apparent. When the SA was reviewed by the leaders of the NSDAP in May, it had grown to include three sturm brigades and one motorized brigade plus a band. 35 Pfungstadt's SA made an impressive sight as it marched to another one of its meetings or rallies. On June 24 the whole SA, led by its band, marched to Darmstadt to take part in a Nazi program. 36 following the integration of the vast majority of the workers into the SA, the NSDAP had two valuable levers with which they could control the working class of Pfungstadt. On the one side stood the officials of the state (town administration), on the other stood the Nazi party. The chances of a man escaping the power of both to direct his life were very remote.

To balance two months (March and April) of harassment the NSDAP staged, in coordination with the national party, a most memorable celebration on May 1. First a notice of the impending festivities was released to the 
public on April 22.37 It was the signal for all of pfungstadt's clubs to swing into action under the guidance of the NSDAP. The preparations for the National Day of Work became so complex that many clubs had to place notices in the Anzeiger to alert their members to last minute changes. 38 one of the most sad groups in the work surrounding the day was the Hessischer Volksfreund. Deprived of its real purpose the volksfreund carried the unheard-of slogans "A strong Germany must have a strong army," and "the national Union calls on all union members to take part in the National Day of Work."39 (For the efforts of the Volksfreund they incurred only false respect. The Volksfreund was banned completely on May 2 when it was no longer needed. $)^{40}$ But the degree of respectability which the SPD paper lent to the occasion was a rich source of support while it lasted.

The zeal of the NSDAP was so great on the occasion of the National Day of Work that the actual celebrations began on April 30 with church services and an SA parade through the streets. 41 The plans for May 1 were more complex.42 They included:

6:00 A.M. SA band marches through the streets to wake up everyone. 
8:00 A.M. Raising of flags on official buildings and businesses

$8: 15$ A.M. to $8: 45$ A.M.

Ringing of bells

8:30 A.M. Gathering of school children at the school

9:00 A.M. Retransmission of the rally from the Lustgarten in Berlin on loudspeakers.

11:00 A.M. to 12:00 Noon

concert at the town hall.

3:00 P.M. Parade through the streets of Pfungstadt.

7:30 P.M. Retransmission of the rally from Tempelhof field in Berlin and the speech of Adolf Hitler.

The response of the populace of Pfungstadt to the plans of the NSDAP was overwhelming. Excluding the disgruntled Union leaders, KPD and SPD officials, nearly every living person in Pfungstadt took part in the Nazi festivities. 43 It was by far the largest gathering of Pfungstadt's inhabitants to have ever taken part in a parade. If there were any remaining doubts in the mind of anyone as to whom the people considered the ruling authority in Pfungstadt, they were buried on May 1. Everyone took part in the parade, which was led by a band composed of city officials. Following them was a contingent of mounted SA, the SA band, the NSBO group, the postal and railroad workers, 
the school children and their teachers, the protestant children's group, the Hitler Jungvolk and Hitler Jugend, the carpenters, the brewers, newspaper workers and printers, construction workers, the bakers, the butchers, barbers and hair dressers, the Krieger- und Militärverein, "German" gymnasts, the Germania soccer club, all of the bürgerlich and some of the workers sirging clubs, and bringing up the rear the farmers and the "old fighters" of the NSDAP. 44 Reaching the town hall, the large crowd was entertained by a mass choir under the direction of the SA man, Hoffmann (formerly chairman of the DVP), before the appearance of the main speakers ortsgruppenleiter Gräff and Mayor steinmetz. The message of the two men was that Germany would exist for Germans, that everyone had the right to work and to food, and that unrelenting firmness of purpose would guide the redevelopment of Pfungstadt. 45 The mixing of promises of relief from the depression far outweighed the vailed threats that were contained in the speeches of both men. People generally looked forward to a brighter future. closing out the events of the day were dances and singing in restaurants throughout Pfungstadt.

The importance of the National Day of Work for the 
further development of Nazism in Pfungstadt should not be under-estimated. In the place of the normally well attended May Day parade of the SPD the Nazis had substituted a day on which both the employee and the employer came together. In place of recriminatory charges from the "workers" and the "capitalists" the Nazis had substituted harmony, however tenuous it was. The thought that they could march in the same parade on May 1 was totally new to many of the working class. Many thought it was the correct thing to do, however. The hatred of the workers was mellowed, and many people decided to see if the Nazis could produce what they had promised. Opposition to the Nazis was weakened once again.

The tools at the command of the NSDAP were many and varied. Besides the party itself, the $S A$ and the NSDO were at the disposal of the Nazis. The NSBO, the Nationalsozialistische Betriebsorganization (the union wing of the NSDAP) was substituted for the Associated Union shortly after May 1. Attached to the change of unions was an ultimatum; either one joined the NSBO or one would lose the right to hold a job. 46 such tactics were common for the NSDAP in Pfungstadt when they dealt with their enemies. The threat to deprive a man of his livelihood was very 
real; several men who did not display enough enthusiasm for their change in union status were summarily dismissed from their jobs. Others were only threatened with a similar fate.47 The working class learned quickly that their own organization would no longer serve the needs of the Nazis.

By late May the role the Nazis had planned for the workers bectame clearer. When the NSBO called a meeting they no longer "requested" the workers to attend, they ordered them to do so. At such meetings the working class people were challenged to become "real Germans" and constructive members of the "new" society. 48 The possibility of existing outside of the Nazi system was not a viable alternative. The base of the Nazi control had continually been expanded while the base of those who were opposed to the Nazis crumbled. By April there had been no question that the NSDAP was in physical control of Pfungstadt; by May there was hardly any question who the people had to support. The controls were increasingly evident in the town of Pfungstadt.

Any aspect of the Nazi program that had not found its beginning in the period before 1933 was instituted after the Nazis seized power in Pfungstadt. As in the 
cases of the SA and the NSBO, the Hitler Jugend and other groups did not have a solid basis. The Nazis soon realized that they would have to rectify the situation. The Hitler Jugend could claim very few adherents before the events of March, 1933. Thus the NSDAP moved first of all in that sector. With the encouragement of their parents, the sons of middle class citizens eagerly joined the HJ.9 The Nazis did not have to force anyone to join because they created something unique--a club for the sons of the bürgerlich. There had never been a group which had been responsive to the needs of those children. For most middle class children the $\mathrm{HJ}$ was an adventure, since they were given many interesting tasks to carry out. Also, the camping, hikes, singing, and dances were all part of a new world the children had never known before. Albert Hochschild, the leader of the HJ, made sure that the outdoor activities of the children were part of the Nazi image, but this the children did not mind. 50 They enjoyed the rallies and recruiting drives that they were a part of. The idealism of the youngsters gave the party a fresh look and a forward-looking image. Many an HJ member firmly believed the words of Hochschild when he said "You will be what your parents cannot be--real National socialists." 51 
Appended to the HJ was the Jungvolk for those too young to take part in the HJ. The Jungvolk were under the direction of the Nineteen year old Alwin Nungessor who many parents thought was not mature enough for the job 52 Nungessor was an idealist. He believed unswervingly in the righteousness of the NSDAP. He followed the lead of the leader of the HJ in organizing his own group. Interspersed between wholesome activities were the political messages of the Nazis. A typical week for the Jungvolk included the weekly meetings, sports, exercises, and a class concerning the political theories of the NSDAP. 53 The Nazis never lost sight of the fact that they had promised to make the children "real" national socialists. The third sector of the NSDAP in regard to the children was organized later than the other groups. The Bund deutscher Mädels (BdM) was not a part of the Nazi system before June, 1933. On June 15 the Anzeiger reported that "because of popular demand" a meeting of interested girls and their mothers would take place on June 16 to found a group in Pfungstadt. Sponsored by the Kreisleitung of the BdM, the meeting was designed to recruit girls between the ages of ten and twenty-one. 54 As in the case of the $\mathrm{HJ}$ and the Jungvolk the daughters of 
the middle class responded favorably to the new group. Within a few weeks the BdM came to rival the size of the HJ. Throughout the entire process the sons and the daughters of the middle class citizens eagerly marched into the ranks of the Nazi sponsored groups. The same was not true of the sons and daughters of working class parents. With few exceptions they remained at a distance from the Nazi institutions, preferring to retain their old ways. The SAJ had been one of the first casualties of the NSDAP, but the spirit of the SAJ lived for a long time in the hearts of its former members. Since the Nazis did not use the same methods or persuasion to enroll working class children in the HJ, BdM, and Jungvolk as they had done to enroll their fathers in the SA, the children stayed away. 55 Before 1933 the working,class youngster had had the opportunity to partake in a variety of outdoor activities while bürgerlich youngsters sat at home. Now the situation was reversed.

As if playing with a large puzzle, the NSDAP put the pieces of its plan for the total control of Pfungstadt into place one after the other. The workers had been first, the town administration second, the children third, and the middle class clubs were to be fourth. The SPD/KPD 
clubs had suffered a fairly quick death at the hands of the Nazis, although SPD clubs did outlast their KPD counterparts. The main thrust of the Nazis was then against the bürgerlich clubs, the clubs of their supporters. The move against those clubs came somewhat later because of the sensibilities of the Nazis to the support of the middle class in general. The "coordination" of the middle class club to the Nazi state thus took more time and involved more diplomacy than many Nazis wished. One by one the clubs received a notice that they would be required to hold special election meetings in order to vote on new chairmen for their clubs. The list of clubs that received such notices was, without exception, complete. 56 Every club, no matter how loyal it might have sounded in the ears of its own members, was subjected to the Nazi indoctrination. The Germania soccer club was one of the first to feel the pressure of the Nazis even though a large number of NSDAP members were on its membership roles. The "German" gymnasts' club held two meetings to elect the proper representatives of the Nazi party to its governing comittee. 57 The cast of characters changed with the club; the outcome never varied. The NSDAP was determined and ale to control, totally, the town of 
Pfungstadt and the lives of each and every citizen. No matter what a person's age, be he six or sixty, the NSDAP had created a group, a club, an organization for him to belong to that brought him into contact with the power and the propaganda of the "Hitler movement."

As the people of Pfungstadt, both young and old, were learning to march in step to the Nazi will, they were provided with many celebrations to ease the transition. This provided them with the intellectual excuse for taking an active part in the Nazi system. Justifying the controls of the NSDAP played a prominent part in Nazi thinking. There was something for everyone. Hitler's birthday was celebrated by the members of the NSDAP on April 20. The members collected money and food for the poor, giving anyone who contributed a receipt. 58 The newspaper reported that the party had collected a substantial amount of money, but not too much food. For the religious there were the Nazi's drives to increase church attendance. The Protestant church in Pfungstadt was again becoining the organ of the people--this was the slogan of the Nazis. 59 This provided the perfect basis for the integration of the religiousiy minded to accept the Nazis. The Protestant church responded by sponsoring a 
political discussion on May 10. Minister Thullner spoke of the plight of the German-speaking people of Hungary on that occasion and called on all protestant and Germanthinking people to suppoct the Hungarian outpost of Germany. 60

The NSDAP itself sponsored the showing of the film, "Blutendes Deutschland;" on May 11, encouraging "our Volksgenossen from the former opposition" to view the film. 61 For those with a bent to the literature of a national nature there were frequent advertisements in the Anzeiger describing newspapers, magazines and books that could be purchased at local bookstores. 62 For those interested in music the party and the SA sponsored concerts and recitals. 63 No one was forgotten by the Nazis as they strove to install their system in Pfungstadt.

In quick succession the town was presented with two celebrations in late May. The first was schlagter. Day. Albert Leo Schlagter was raised to the rank of hero by the French and the NSDAP. The French sentenced him to death for his activities in the Ruinr during the French occupation. The Nazis made him a hero of the Third Reich. The people of Pfungstadt were presented with a packaged celebration to commemorate his feats, and his death, 64 
The SA provided the second part of the festivities on May 28 with the presentation of a vaterländische Veranstaltung. The theme of the meeting dealt with the rebuilding of Germany under the direction of Hitler. The people were once again exhorted to "begin the work of rebuilding Germany."65 capping the successive efforts of the NSDAP to instill in the people of Pfungstadt the Nazi values was the Day of Sorrow for the Treaty of Versailles on June 28 . Once again a sea of black-white-red national flags, swastika flags and banners swirled from the houses of the people. In the town school there was a special assembly, while adults were urged to attend the rally against the Versailles Treaty which took place in Darmstadt the same night. 66 The Nazis were becoming masters of the art of bringing the citizens of Pfungstadt together to directly or indirectly support the new order of the NSDAP.

winning the allegiance of the people of Pfungstadt was the goal of the NSDAP. The means that they employed to accomplish that task had two sides. The one consisted of public displays and festivities, the other was the descriminating use of force. Anyone who had had a hand in the SPD, the KPD, the Associated Union, or one of the organs connected to those groups was subject to the 
search of his house at any hour of the day or night, questioning and sometimes detention at the town hall, and threats against himself and his family. 67 while the midde class citizen could report that his life was little changed by the Nazi seizure of power, the worker lay awake at night not sure if he would be the target of some new Nazi charge. The SA Hilfspolizei were particularly obnoxious in their handling of individual workers. At one point the Hilfspolizei had to be warned that only the regular police had the authority to arrest and hold suspects. 68 over fifteen former SPD/KPD leaders were arrested on the night of May 4/5, some receiving a severe beating from the "authorities." Other people were introduced to the power of the Nazis through a visit to the proto-concentration camp osthofen. ${ }^{69}$ Rumors spread so fast and with such amazing intensity that the party was forced to publish an article in the Anzeiger which attempted to depict the concentration camp as a "rehabilitation center for former oppositional leaders."70 while osthofen was not the model institution which the NSDAP tried to depict it to be, it was not as fearful as some concentration camps which were to come later. ${ }^{71}$ osthofen was a crude collection of barracks-like buildings which had 
once been a paper factory. Some of the first inhabitants of Osthofen were brought to the camp more for their skill in a particular trade than for their political errors. Thus one former KPD member was arrested and taken to Osthofen because he was a bricklayer. Carpenters and electricians were also recruited in a similar manner. ${ }^{72}$ The existance of Osthofen was well known, although little discussed in Pfungstadt. Middle class citizens generally did not believe that it was a jail, preferring to believe that it would really be used to re-educate people. The Anzeiger sustained the view of the bürgerlich by reporting that Osthofen was the center of re-education by referring to "marxists" and"opposition leaders" when it reported anything about osthofen. No one identified by name as having been a resident of Osthofen, and the Nazis soon realized that all of the publicity given to the camp was building up pressure in the ranks of the workers. After a report of the crash of a car from Pfungstadt which was taking "marxists" to Osthofen on May 23 the Anzeiger reported on the camp only once again and then ceased mentioning the camp entirely. 73

Resolved to eliminate all of the remaining vestiges of the KPD and the SPD, the NSDAP went to the extreme 
measure of publicly inserting an article of warning in the Anzeiger against any firm that they considered to be "communistic." A person did not have to be a KPD member to qualify for such label. Nearly all of the firms in Pfungstadt had been against the KPD and, for that matter the SPD, throughout the period before 1933. A few were not or had had some member of the family that had been associated with one of the groups, most often the SPD. The old owner of the Anzeiger, Jacob Helene, had been a secret member of the SPD while his nephew, Gottfried Helene, the actual editor of the paper, was a member of the DVP. Gottfried Helene was in charge of the paper as the NSDAP gained more and more support. He pragmatical1y refused to carry any KPD or SPD advertisements before the March 5, 1933, election, but was, none the less, threatened by Mayor steinmetz with the loss of the ownership of the paper unless he joined the party. This he did. The activities of the paper were closely supervised by the local NSDAP and the Gaupresseamt. Gottfried Helene had to attend a monthly meeting of the Gaupresseamt and submit daily a copy of his paper for their approval ?4 $^{4}$ In another case the wrath of the NSDAP was more complete. A bakery was closed by the police on May 23 after the 
citizens of Pfungstadt had been notified of the man's connection with the KPD and warned not to buy from him. The SA sent a detachment of its people to watch the people who entered the establishment and to write down their names. 75

The objective of the NSDAP was to take over all public links to the people, from any source, that they considered to be at odds with the Nazi state. This included the director of the school and three of his teachers. The director was removed from his post at the beginning of May while the three teachers were informed that they were being transferred to other towns on June 1. 76 The teachers had first been forbidden to teach history, then religion; then they were moved. One of the teachers involved was actually thankful to the authorities for their decision to replace him, because he feared that he and his family would have been subjected to severe retribution if he had stayed in Pfungstadt. 77

On June 22 the final blow fell against the organized workers of Pfungstadt when the SPD was officially banned?8 Long before the decision was made to forbid the SPD the group had ceased to operate in Pfungstadt. But the banning of the party began a new round of searches and 
intensive police surveillance of the former leaders of the SPD. One day shortly after the banning of the party, the old leaders of the SPD found out how welcome they were in Nazified Pfungstadt. All of the leaders of the SPD and the KPD were ordered to report to the town hall. Once assembled there they were informed that they would not be allowed to hold any jobs in Pfungstadt or the surrounding area and that they would have to register with the police everyday--at 8:00 A.M., at noon, and in the evening. ${ }^{79}$ so began a period of intensive hardship for the men and women who had carried the banners of democracy and communism; the period of trial was to last over one year. The leaders reacted by feeling a complete aversion to anything that had to do with politics. ${ }^{80}$ The circle of Nazi control had been closed. There was no escape.

With deliberate purpose the Nazis had moved to choke the life out of any remaining opposition to the NSDAP. At the same time they had moved to place their own organizations and groups before the people. The membership of the NSDAP had taken control of the clubs of Pfungstadt; the Protestant church was tacitly supporting the party; the administration of the town was firmly in the party's hands. Nazism, the "solution" no one really 
understood, had become the master of Pfungstadt. They, the people, would now learn what Hitler and his followers haa said, but which the people had failed to understand. 


\section{CHAPTER XIII - FOOTNOTES}

IInterviews with Julius winkler, Fritz Feldmann and Karl Emig.

2Interviews with Jacob Hanbuch, Johann Kölsch and Julius Winkler.

3 Interviews with Wilhelm Kaffenberger, Adam Ruckelshausen, August Hechler, Karl Hechler and Johann Kölsch.

${ }^{4} \mathrm{PA}:$ March 28, 1933.

${ }^{5}$ Interviews with Julius winkler and Peter cröpmann.

6 $\mathrm{PA}$ : April 1, 1933 and interviews with Heinrich Schaffner, Maria Schulz, Karl Emig and Julius Winkler.

${ }^{7}$ Interviews with August Hechler, Georg Herth and Heinrich Sand.

${ }^{8}$ PA: April 5, 1933

${ }^{9}$ Interviews with wilhelm Kaffenberger, Heinrich Sand, August Hechler and Jacob Delp.

$10_{\mathrm{PA}}$ : March 23, 1933.

${ }^{11}$ PA: April 3, 1933.

12 Interviews with Heinrich Sand, Wilhelm Kaffenberger and Luise steinmetz.

${ }^{13} \mathrm{PA}:$ April 20, 1933.

${ }^{14}$ Interviews with Jacob Brauer, Julius Hofmann, Maria Schulz and Georg Liebig.

${ }^{15}$ PA: April 22, 1933. 
16 Notes from the file of August Hechler.

17PA: April 25, 1933.

18 PA: May 9, 1933 and PGSP: May 8, 1933, pp. 397401.

$19 \mathrm{PA}$ : June 1, 1933; notes from the file of August Hechler; Karl Hechler, 75 Jahre SPD ortsverein Pfungstadt in 75 Jahre SPD Ortsverein Pfungstadt, p. 51 . . 1967).

$20_{\mathrm{PA}}$ : May 22, 1933 and HVF: April 24, 1933.

${ }^{21}$ PA: May 19, 1933 and PGSP: May 18, 1933, pp. 402409.

22PA: April 24, 1933.

$23 \mathrm{PA}$ : May 8, 1933.

${ }^{24} \mathrm{PA}$ : June 8, 1933.

${ }^{25} \mathrm{PA}$ : May 20, 1933.

${ }^{26} \mathrm{PA}$ : March 31, 1933.

27 Interview with Jacob Brauer.

${ }^{28} \mathrm{PA}$ : April 24, 1933.

${ }^{29}$ Ibid.

${ }^{30}$ Interviews with Jacob Delp, Peter Crößmann, Georg Herth and Georg Liebig.

${ }^{31}$ Interviews with Jacob Delp and Johann Kölsch.

${ }^{32}$ Interviews with Georg Herth and Georg Liebig. 
${ }^{33}$ Interviews with Jacob Delp, Johann Kölsch and Peter cröpmann.

${ }^{34}$ PA: April 10, 1933.

35PA: May 8, 1933.

${ }^{36} \mathrm{PA}$ : June $26,1933$.

${ }^{37}$ PA: April 22, 1933.

${ }^{38} \mathrm{PA}$ : April 27 and $28,1933$.

${ }^{39}$ HVF : April 29, 1933.

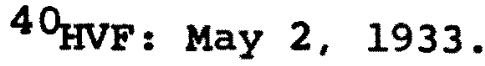

${ }^{41} \mathrm{PA}:$ May 2, 1933.

42 Ibid.

${ }^{43}$ Ibid and interviews with Georg Liebig, Karl Emig, Johann Kölsch and Jacob Delp.

${ }^{44} \mathrm{PA}$ : May 2, 1933.

45 Ibid.

${ }^{46}$ Interviews with Karl Emig and Johann Kölsch.

47 Interviews with August Hechler, Georg Liebig and Jacob Delp.

${ }^{48} \mathrm{PA}$ : May 31 and June 26, 1933.

${ }^{49}$ Interview with Maria Schulz.

$50 \mathrm{PA}$ : May 22 and 23, 1933. 
$51_{\mathrm{PA}}$ : June $24,1933$.

52 Interview with Julius winkler.

${ }^{53} \mathrm{PA}:$ June $12,1933$.

${ }^{54} \mathrm{PA}:$ June 15, 1933.

${ }^{55}$ Interviews with Jacob Delp and Karl Emig.

${ }^{56} \mathrm{PA}$ : March 29, April 3, 9, 10, 13, 15, 19, 25, May 5, 9 and 13, 1933.

${ }^{57} \mathrm{PA}$ : March 31 and May 4, 1933.

${ }^{58} \mathrm{PA}$ : April 21, 1933.

${ }^{59} \mathrm{PA}:$ April 21, 1933.

$60_{\mathrm{PA}}$ : May 10, 1933.

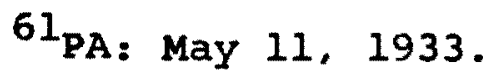

${ }^{62}$ PA: Nay 12, 1933.

${ }^{63} \mathrm{PA}:$ May $20,1933$.

${ }^{64} \mathrm{PA}:$ May 27,1933

65PA: June 3, 1933.

$66_{\mathrm{PA}}$ : June $29,1933$.

${ }^{67}$ Interviews with Karl Emig, Georg Liebig and Peter cröprann.

${ }^{68} \mathrm{PA}:$ June $28,1933$. 
${ }^{69}$ Interviews with Georg Herth, Peter crößmann and August Hechler.

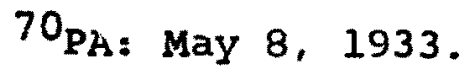

${ }^{71}$ Interviews with Jacob Delp and Georg Herth.

${ }^{72}$ Interviews with Peter crößmann and Jacob Delp.

${ }^{73} \mathrm{PA}:$ May 23, 1933.

${ }^{74}$ Interview with Gottfried Helene.

${ }^{75} \mathrm{PA}$ : May 23 and 9, 1933.

${ }^{76} \mathrm{PA}:$ May 8 and June $1,1933$.

${ }^{77}$ Interview with Julius winkler.

${ }^{78} \mathrm{PA}$ : June $23,1933$.

${ }^{79} \mathrm{PA}$ : July 3, 1933 and Interviews with August Hechler, Georg Herth and Peter crößmann.

${ }^{80}$ Interviews with August Hechler and Peter Crößmann. 


\section{ADJUSTING TO NAZI ORDERS - JULY TO OCTOBER, 1933}

Splitting the executive authority of the town administration from the direct control of Ortsgruppenleiter Gräf gave the members of the town councli more power than was normally the case in Naz1 Germany. The Ratsherren, as the town counc1l members were called after April, 1933, aid not possess the independence of their pre-1933 predecessors, but they did hold a large quantity of power in relationship to the Nazi party organization. Mayor Steinmetz and Vice-Mayor Martin were loyal members of the NSDAP who could be relled upon to follow the broader dictates of the Nazl party, but they had flrm bellefs of thein own on strictly local matters. ${ }^{I}$ Since their political fortunes had not been molded in the caldron of Nazi election victory, they moved with speed to enact their financial phllosophy. The objects of Steinmetz-Martin's fiscal "reform" would first of all be the unemployed and secondly the middle class businessman. The middle class businessman wculd still have to pay the major portion of the b11I, whlle the unemployed would have to suffer the results of Steinmetz-Martin's flscal policy. Small amounts of the funds were cut from the budget at the July 1 
meeting at the expense of the unemployed. Funds were cut from the appropriation for the use of the town's swimming pooi and ient support. ${ }^{2}$ Azso on tise agenda was the appointnebt of Karl Polster as a policeman which enhanced the NSDAP Image in Pfungstadt because his reputation for falrness. 3

By August 18 the Naz1 members of the town counc1l were ready to tackle the budget for 1933/34. Mayor steinmetz quickly made it clear that with the "bolsheviks" eliminated from the council and "unnecessary" criticism curtalled that the council could approve the budget in one session instead of the many it had taken in previous years. Taxes he sald would not be ralsed (but not lowered elther). 4 The budget 1tself would be nearly one hundred and ten thousand marks smaller than the $1932 / 33$ budget, the most notable cuts coming in the areas of town unemployment assistance (cut one hundred and three thousand marks) and town administration (cut nearly ten thousand marks). Smaller cuts took place in the allotments for the construction and malntenance of streets and townowned housing. 5 The sharp drop in the amount of assistance allotted to the unemployed fit into the program of Steinmetz-Martin and the other Nazis perfectly. The warnings of the SPD (and KPD) that they were ant1-labor, ant1union, anti-soclal were proving to be all too true.

It is not clear if the drastic curtailment of the 
town unempioyment compensation section of the budget was a calculated gamble on the part of the Nazis that they would create joos by the $t_{\perp}$ ne funds ran out or not. In any case the council or the state would have to balance the potentially disasterous cuts in the budget with employment for those st11l without work if a wave of discontent was rot to sweep through Pfungstadt. A step toward providing the necessary alternative to unemployment compensation expenditures was taken as early as July when the town administration announced that sixteen emergency homes would be constructed on the seehelmerweg in the near future. The labor for the project was to come from the unemployed, the land from the town, and the money from the Reich. The most important factor in the calculations of the town administration was the money from the Relch. Nearly flfty thousand marks would be needed to set the project in motion. ${ }^{6}$ A conflict of interests and pillosophy developed speedily over the program since stelnmetz and Martin had bullt their reputations on the determined resistance they had shown to all of the pre-1933 spending programs of the SPD. Only a few months earlier they had turned down a fifty-six thousand mark loan offer with the remark that the town could not afford 1t. But in the case of the settlement on the Seehelmerweg the pollcles of the NSDAP had to take precedence. Orders were delivered to the Mayor and the town council that the state govern- 
ment and the Nazi party were pushing such projects as a means of alleviating some of the rampant unemployments. 7 T5 $\geqslant$ power of Steinmetz and Martin so control the fiscal as weli as the polftical destiny had certain limits, limits that the fixed lieas of the town men could not breach. Naturally the town administration moved to take full credit for the institution of the settlement once the 1ssue of the proprlety of the project was decided by Naz1 authorities above the local level. 8 The strange twist of fate that had brought Stelnnetz and Martin to the leading offices of the town now made them into the prophets of "reasonable debt" In the cause of the Naz1 party. The utter opposition that they had shown to the SPD proposal to bulld streets, also with a fifty thousand mark Relch loan, was replaced by a selî-serving readiness to accede to the w1ll of the Naz1 party. The polftical dance they would do would become even stranger as the hold of the Nazis over the levers of power became more assured. The worst type of political expediency had trlumphed. In conjunction with the Seehelmerweg settlement profect was the construction of a road to connect the towns of Seehelm and Pfungstadt. Running through the settlement homes the road was also intended to provide jobs for the unemployed. The project was also to be flnanced by a Reich loan. ${ }^{9}$ In this particular sase the Nazls had not even shown any orlgirallty--the Seehelmerweg 
profect was the direct decendent of a SPD proposal of exactly the same speciflcations. But the most lasting rellef from the unemployment problem would have to consist of something bigger than elther the road to Seeheim or the settiement on the Seehelmerweg. That something was to be for Pfungstadt the construction of the autobahn. The first notion that the people of Pfungstadt had that the plans for the autobahn had progressed very far (they had known of the existance of the plans for the Hafraba autobahn for some time) past the mere plannign stage came on July 7. The Anzelger briefly mentioned that the autobahn would go through quite a section of Pfungstadt's westerly forest and farm land. The paper noted that "We can be thankful that our town's administration is dolng so much to try and relieve unemployment."10 No mention was made of the men who had originaliy designed the Hafraba system when the paper made the announcement on July 14 that the final approval had been given for the construction of the autobahn section between Frankfurt and Mannheim. A note accompanied the article stating that "the 'new' plans of Adolf Hitler have absolutely nothing to do with the Hafraba 1deas." 11 If the Naz1 town administration of Pfungstadt could claim credit for the autobahn with a straight face, then there was no reason

* The first section of autobahn constructed anywhere in Germany under the Nazis. 
Hitler could not do the same. By August 1 the owners of property along the route of the autobahn (for the route of th. autobihn near Pfungstadt see page.3.) had been given notice that they would have to sell. ${ }^{12}$ The owners of the property were exclusively farmers. The authoritarian manner in which the prices were set (there was no bargaining) upset the farming conmunity. Some farmers took their complaints directiy to the mayor-without success--as to: a change in price. ${ }^{13}$ While the farmers disputed the fairness of the purchase of their land when they met for a glass of beer, the construction company owners of Pfungstadt were refolcing. The mayor specifically promised them that they would recelve a fair share of the construction business when the time for bullding began. 14 The mayor also promised that all the unemployed would find a place for thernselves avallabie--with one exception. Those who did not belong to the SA would be unable to find work. The workers had been Informed of this threat as early as March (aithough 1t did not concern jobs on the autobahn at that time), but had not taken it as seriously as they did in August since there had been few jobs for the Nazis to offer the unemployed. ${ }^{15}$ Now a real reason for the unemployed existed, a concrete carrot with which the Nazis could coerce the wavering unemployed into the ranks of the SA once and for all.

For ail of the pronises of the NSDAP in the months 
after March, 1933, the economic tempo of Pfungstadt did not plck up. ${ }^{16}$ To be sure there were a few new jobs c:-eated, Jut the fundamenatl breakthrough to full employment was still a way off. Nothing speclal was undertaken for the small businessman of Pfungstadt although the department stores of Darmstadt had been closed. Nothing speclal was done for the farmer although he had provided a solid block of Nazl votes. Nothing speclal was done for the workers although he might expect a job working on the autobahn if he corrected his political outlook. NothIng special was done for any segment of the town's economy; the summer months saw the perpetuation of the depression. The Naz1 answer was st121 to come.

In the place of jobs and useful work the Nazis provided the people of Pfungstadt with an endless stream of programs, meetings, gatherings, celebrations and assemblies. The series of Schulungskurse which had been earlier was continued, although at a slower pace. Membership meetings of the newiy enrolied "March recruits increased markedly. Attendance at the July 21 meet1ng was mandatory and the members were instructed to bring their identification cards with them to prove their presence. Kre1sle1ter Zürtz used the opportunity to reenforce the support of the NSDAP for Ortsgruppenleiter Gräff whose ego had been bruised when he was not appointed mayor. The Krelsleiter praised the work of the NSDAP in Pfungstadt, but reminded the members pre- 
sent that they had to attend at least one if not two pol1tical education meetings a month. He warned the members not to listen to "critic1sm that ve did not have a nevoIution. The Führer did not want a blood bath, he wanted an Internal reordering of the German.soul." He then promised the "old fighters" jobs and food. 17 The Nazis continued the policy of interspercing political education meetings between NSDAP membership meetings. A Schulungskurs was scheduled for July 31 while a membership meetIng took place on August 21.18 Kreisle1ter Zürtz returned to Pfungstadt for the August 21 meeting bringing with hIm the message that the unemployment problem had Its roots in seventy years of bad governmental administration. Bismarck was the only promentent statesman to be spared from his anger. H1s two hour speech ended with the promise that the NSDAP would restore the workers to the jobs they needed. Three S1eg-hells closed the meeting. 19 The NSBO Joined in the spate of Naz1 meetings that took place in July, August and September with an assembly of their own on August 13.20 The women of Pfungstadt were also not forgotten; the Nationalsozialistische Frauenschaft held meetings in both August and September. ${ }^{21} \mathrm{~A}$ highpoint in party activity was reached in the early days of September when the SA band lead an NSDAP parade through the streets just before a thirty-two member contingent of party falthful left for the Nürnberg party meeting. The process was 
repeated when the party members returned on September 4.22

For those who did not relish all of the party activitles there were a number of other events that they could joln. A gilder club was established in early July. Just1flcation for the undertaking was provided by the new leader of the group, Adolf Ruckelshausen (no relation to Adam Ruckelshausen), with the words, "Flylng is 1mportant for the Fatherland."23 Even in the Fliegernest meetings the role of the NSDAP as the leading group in Pfungstadt was strongly accented. When a former SFD member ralsed an objection to the speech of the town school's director, Born, because of his attack on the Jews, he was pointedly told to keep quiet by Ortsgruppenlelter Gräff. The next day he was taken to Mayor Steinmetz and told he would not be allowed to attend any more meetings unless he registered with the mayor's office ahead of time. 24

The school chlldren were busy with their own project. Over a two day perlod they collected one hundred and eighteen marks for the Association for Germans in Forelgn Countries. 25 The NSDAP itself tried to use non-political occassions for thelr own ends often. In July the SA sponsored two concerts which contalned a dose of propaganda along with the mustc. In August the NSDAP furnished the town with a singstunde. 26 an inordinate emphasis on "nationally inspired" songs found their way onto the program. Other activities included the Sommerfest dances 
sponsored by various clubs and restaurants, and the gymnastics club Sommerfest itself. ${ }^{27}$ The gymnastics club also cclebrated the departure of twenty-eight participants in a gymnastics rally in Stuttgart with a parade and speeches. The SA band was on hand to honor the gymnasts when they returned. 28 No event was to small for the Nazis to play a role in, and exploit for their own propaganda 1mage. The same was true of the outwardly innocent fire department exercises on July 9. The district fire inspector was on hand to see the demonstration, as was Mayor Stelnmetz who used the occassion to say that "the citizens of Pfungstadt still do not appreciate the fire department enough." 29 He was referring to the fact that since the "coordination" of the fire department some workers had quiletly crossed their names off the roles.

Nothing, no one was overlooked by the Nazis in their search for the total control of Pfungstadt. The Kriegeru. M111tärverein preserved its independence during the first four months of the Nazi regime, but late in July succumbed to the Nazi demand that they coordinate their group also. In the Rhelnische Eof restaurant, decorated with the picture of Adolf Hitler and the black-white-red and swastika flags, the membership learned that they were to become ariother cog in the Nazi's political machire. The NSDAP party member Peter Seeger replaced the previous chalrman of the group and announced that the club would 
promote more awareness of the necessity of Germany belng well armed. He also informed the members that the club would cooperate with the SA in the construction of a shootIng range in Pfungstadt. The Verein contributed one hundred and ten marks for the SA project. ${ }^{30}$ By August 26 the shooting range was opened. Everyone who was sixteen and not a member of the $S A$ was asked to joln. The cut of date for enrollment was set for September 2. Additional Insplration was supplied by reminding the populace that "Shooting is a Volkssport today." 31

For those hwo would not mold themselves in the Nazt system, or the Naz1 system would not accept, I1fe was very hard. A young man was accused of stealing apples for his mother and had to parade around the streets, shouting that he had robbed a Volksgenossen on several street corners. Two men had to march around with potatoes they were accused of taking with a sign "stolen" on their backs in the middle of August. The ready sentencing of people accused of stealing found another victim on September 9 , when Franz CröBmann (no relation to Peter CröBmann) had to wear a banner saying he had stolen potatoes from a farmer. ${ }^{32}$ The NSDAP wanted to identify itself closely with "order" and for the solution of the problems the farmers had had for years with the unemployed who tried to suppliment their meager unemployment pay with stolen food. The numerous cases of people taking foodstuffs from farmers also 1llus- 
trates the continued impact of the depression on Pfungstadt. Nothing upset the Naz1 masters of Pfungstadt more than to think that there were stili pockets of resistance to their rule. The most stringent measures were called for when the Nazis belleved that someone broke the outwardly solld facade of their realm. On July 21 the Krelsamt and the Bürgerme1stere1 of Pfungstadt imposed the most stringent rules for those who were lmplicated in the distribution of pamphlets of opposition. The mayor ordered that: 1) anyone who found or recelved a pamphlet was to turn it over to the police or face the severest penalty, 2) all former SPD and KPD leaders be placed under arrest and strict police observation when a pamphlet was discovered and 3) the pollce were to Immediately use their guns to suppress any distribution of Flugblattern. ${ }^{33}$ The heavy hand of the Nazis fell on Georg Llebig who was arrested for distributing leaflets. He was sentenced to two and one-half years in prison. 34 The Nazis had moved once again to utterly destroy even the most insigaificant opposition. Nazl hatred of thetr former political opponents had not mellowed since they had selzed power on March 7. The ugly portion of the Nazis had first been efidenced during March when nightly searches of homes for guns had gone on; when SPD, KPD and Associated Union offlclals were arrested and lodged in the town hall's jall. An imdication of the hatred that remalned in the hearts of some NSDAP members 
was revealed to many when SPD/KPD people were routinely taken to the Osthofen concentration camp. But on the n'ght of lugust $22 / 23$ the most reprehensible, the most detestable sort of Nazis emerged from behind their masks of "equality for all Germans." They were to scar their souls with guilt for a lifetime.

Late on the evening of August 22 rifle-toting SA men rounded up all of the former Relchsbanner, SPD, Assoclated Union and KPD leaders the Nazis had some suspicion of. 35 The SA later clalmed that the entire operation was aimed only at KPD members who were hiding guns, but the truth was they wanted to settle some old scores. ${ }^{36}$ at the town hall over elghty men were herded into the town's small ja11. There they were informed that they were in protective custody. Half the night was spent in the cramped quarters of the jali before the men were taken one by one to the ground floor of the town hall where a SA Sturmführer sat surrounded by armed $S A$ men. In the middle of the desk placed in front of the sturmführer was the man's knlfe, which he pulled out every so often only to plunge It viclously back into the table while he warned the man he was questioning, "The night of the 'long knives' is st1ll to come." August Hechler had the luck to be the first man brought before the SA tribunal. After being questioned about the location of the guns the Nazis felt were st11l hidden in Pfungstadt, Hechler was escorted by 
the same SA men who had brought him to the town hall to his parents home and released. 37 The men who followed Huchler were not so Iucky. As each man cla1med that he knew nothing about any guns, the anger of the sturmführer grew more interse. Of the over elghty men who were brought to the town hall only seven were spared a beating. Over seventy men were mishandled, at least two had to sperd several weeks in a hospital recuperating. 38 one was the future mayor of Pfungstadt Ludwig Clemenz. For all of the Nazi effort only two guns and one hundred and elghty rounds of ammunition were discovered in two hotwater bottles. 39

The severity of the Nazi action unleashed a reaction with the ranks of the NSDAP itself. Several long-tine members of the party, who had 1dealistically viewed the Nazl rise to power, complained bitterly that the beatings were the worst sort of propaganda for the party and contrary to their 1deals. The majority of the membership kept their thoughts to themselves. They were not the masters of the party, the party was their master. The average citizen did not want to know anything about the beatings. 40

Conquering the power structure of Pfungstadt had been one problem for the NSDAP, remaining in power was another. The Nazis had attempted to dent the animosity of the workers and some bürgerlich through a serles of displays, celebrations, and events which stressed the 
nationalistic spirit of the Nazis. But the Nazis were playing the game of power for keeps; they would tolerate ri opposision, no matter how small. The events of August $22 / 23$ were more representative of the true nature of Nazlsm than anyone of the NSDAP members would belleve. The SPD (and KPD) had warned the people that that sort of thing was part of the very soul of Naz1sm but the büngerlich had refused to listen. The fruits of that enormous failure to perceive the truth were plainly evident for all but the most nalve citizen of Pfungstadt to see. 
CHAPTER XIV - FOOTNOTES

${ }^{1}$ Interviews with Heinrich Sand, Wilhelm Kaffenberger, Jacob Hanbuch and Jacob Brauer. 409.

2PA: July 3, 1933 and PGSP: Jlily 1, 1933, pp. 406-

3 Interviews with August Hechler and Georg Liebig. Hechler reported that one time as he entered the town hall to register with the police he falied to give a secretary the mandatory Hell Hitler. The secretary became insensed, but was put in his place by Polster who told the man to have more understanding for Hechler. $410-414$.

4PA: August 19, 1933 and PGSP: August 18, 1933, pp.

${ }^{5}$ Rechnung über E1nnahme und Ausgabe der Gemelnde Pfungstadt für 1933734, pp. 35 and 96 .

${ }^{6}$ PA: July 5, 1933. Sand.

7 Interviews with Wilhelm Kaffenberger and Helnrich

${ }^{8}$ PA: August 1, 1933 and November 1, 1935

${ }^{9}$ PA: August 26, 1933.

10 PA: July 7, 1933.

${ }^{11}$ PA: July 14, 1933.

${ }^{12}$ PA: August 1, 1933.

${ }^{13}$ Interviews with Ludwig Gunkel and Peter Crößmann.

14PA: July 3, 1933 and Interview with Jacob Brauer.

${ }^{15}$ Interviews with Johann Kölsch, Karl Entg and Georg Herth. 
${ }^{16}$ Interviews with Ludwig Wenz, Fritz Feldmann, Jacob Brauer, Helnrich Sand and August Hechler.

${ }^{17}$ FA: July 20 and $2 \hat{z}, 1933$.

${ }^{18}$ PA: July 31 and August 1 and 21, 1933.

${ }^{19} \mathrm{FA}$ : August 22, 1933.

${ }^{20} \mathrm{PA}$ : August 12 and $14,1933$.

${ }^{21}$ PA: August 25 and September 21, 1933.

${ }^{22}$ PA: September 2 and 5, 1933.

${ }^{23}$ PA: July 4, 1933.

${ }^{24}$ Interview with Georg Liebig.

${ }^{25}$ PA: Julay 1, 1933.

${ }^{26}$ PA: Jyly 8 and 29 and August 8, 1933.

$27_{\text {PA: July } 8,1933 .}$

${ }^{28} \mathrm{PA}$ : July 25, 31 and August 1, 1933.

${ }^{29}$ PA: July 10, 1933.

$30_{\mathrm{PA}}$ : July 22, 28, 31 and August 4, 1933.

${ }^{31}$ PA: August 26, 1933.

32 PA: August 7, 10 and September 9, 1933.

33PA: July 21, 1933 and interviews with Jacob Delp and Gerog Herth.

34 Notes from the flle of August Hecinier and interviews with August Hechler and Georg Llebig. 
${ }^{35}$ Interviews with Peter Crößmann and August Hechler. ${ }^{36}$ Interviews with Helnrich Schaffner and Wilhelm Kaffenberger.

37 Notes from the file of August Hechler and interviews with August Hechler and Jacob Delp. The NSDAP clalmed that the entire operation was under the leadership of $\mathrm{SA}$ mien who were not from Pfungstadt. W1lhelm Kaffenberger sald that the men were from Berlin.

${ }^{38}$ Notes from the file of Helnrich Huxhorn and intervlews with Georg Herth, Peter Crößmann and Karl Hechler.

${ }^{39} \mathrm{PA}$ : August $23,1933$.

${ }^{40}$ Interviews with Heinrich Sand, Jacob Hanbuch, Marla Schulz, Peter Crößmann and Ludwig Wenz. 


\section{CHAPTER XV}

THE NEW MASTERS - OCTOBER, 1933 TO JANUARY, 1934

By October, 1933, the new masters of Pfungstadt had become accustomed to firmly sitting in ali of the seats of Importance in the town. So self-assured had the leadership of the Nazi party become that they declared that anyone who accepted the new state had to fly only the swastika flag. The authoritarian order of the Nazid followed similar pronouncements that the Hitlergrup was mandatory In the school and that every citizen should use the Deutschegrup in everyday conversation. ${ }^{1}$ The degeneration of the NSDAP members into Nazis (the tearing down of all normal restraints) was typified by the speech of "race relations" at the November 15 NSDAP members' meeting given by school director, Born. Born also brought his 1llogical assortment of half truths and outright lies to the NSDAP's Schulungkurse in the middle of December. ${ }^{2}$ Born's display of ignorance represented the ultimate lowness to which the Nazis of Pfungstadt could fall. Unfortunately, there was no one left to publicly balance the distorted propaganda. Inflicting warped political views on the citizens of Pfungstadt had become a full time hablt of the NSDAP. A foint

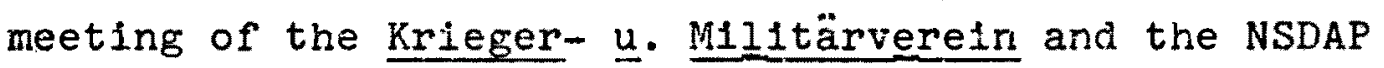


provided a forum for the distribution of a complete set of twisted nationalistic diatribes. ${ }^{3}$ At the December 19 Schulungsabend of the NSDAP party nember Borchert e::plained how proud he was that "the German worker had found the way to the Führer without having had to engage in clvil war." Acknowledging that many workers had not fully accepted the Nazl state, he predicted that it might be fifty years before Nazims was fully infused into the people. The children he sald had been won to the Führer. He closed by saying that "the order we again have in Germany is the work solely of Adolf Hitler." 4 Anything and everything was clalmed by the Nazis as proof for thelr party.

The NSBO recaptured the momentum it had lost to other clubs and groups during the summer late in the year. Applications for the group, the leader Fritz Gunkel (no relation to Ludwig Gunkel) reported, would only be accepted unt1l December 31.5

Working within the Nazl system proved for the most part an easy task for the members of the town counc1l. In all but the most important cases (work projects) the council followed the principles of Steinmetz and Martin. The law of the two men was to cut expenses wherever possible. The end of 1933 saw the council making real strides in cutting varlous small expenses. Martin was so overjoyed at the progress that had been made concerning the payments to the unemployed that he predicted that the town would have 
eliminated the welfare payment burden by the end of the year. ${ }^{6}$ While his assesment of the situation proved too optimist1c, the town had tiken, at the insistence of the state and national governments, the first faltering steps back toward economic recovery. One means at the disposal of the town counc1l was the Arbeltsdienst (labor service) which had enrolled two hundred and sixteen men by November, 1933. ${ }^{7}$ The construction of special projects, projects the SPD had proposed earlier, was the basis for the recovery of Pfungstadt. A case in point concerns the Arbeltsdienst. In November the councll approved plans for the construction of an Arbeltsdlenst headquarters in Prungstadt. The SPD had not pushed for the project before 1933 for fear that Stelnmetz, Martin and their assoc1ates would veto the plan. But times had changed. In place of the vicious attacks of Stelnmetz and Martin on the "Irresponsible economic policy" of the SPD were the orders of the Relch government and the Naz1 party. The Seehelmer settlement is yet another example. The Seeheimer road profect yet another. For the bullding of the Seehelmer road, Martin happily reported to the counc1l, fifty to seventy men would be employed for up to six months thus reducing the rolls of the unemployed. ${ }^{8} \mathrm{~A}$ commendable realrection of the labor force, the seehelmer project had been fought by Steinmetz and Martin as wasteful before 1933 . The change in bürgerlich thinking concerning fiscal matters 
undoubtedly benefited the average man in Pfungstadt; the Nazis took full credit for the economic recovery they had frught sush a short time before. Nork on the Seehelmer settlement proceeded falrly rapidiy. Initialiy only sixteen homes had been planned, but the number was ralsed to elghteen by October with the majority of the homes curiously deslgnated for former SPD and KPD members. The "old fighters" grumbled. 9 The seehelmer road cost the town over thirty-one thousand marks and was according to Naz1 propaganda, a profect designed to "fulfill the wishes of the people." 10 The wishes of all the people were certainly a new concern for Steinmetz and Martin who had so often jumped to their feet before 1933 to labei any talk of more housing and more roads "foolishness in light of the economic state of Pfungstadt." 11

Near Darmstadt construction of the autobahn began in the middle of October when detours and other essential preIIminary work was completed. By November 14 the autobahn project had penetrated the forest of Pfungstadt. Surveyors were busy mapping out the route through the area under Pfungstadt's administration. Cold weather slowed the huge project somewhat late in November, but the Anzeiger was finally able to report that actual construction had begun on December 4.12 The autobahn work, the Anzelger reported, was the chance for everyone to find employment. Indeed the fob-creating potential of the autobahn was enormous, 
especlally since the work was to be done with a minimum of machines. The political consequences of the construction of the autobahn and the otiner profects is very difflcult to measure. Many men resented thelr forced entry into the SA, whlle at the same time they felt grateful at the chance to find work. ${ }^{13}$ The bürgerlich businessmen greeted the work w1th glee, because they were often directly responsible for some of the construction. Those that were not Involved in the project expected the reemployed workers to begin pumping some money into their stores. There was no sudden burst forward in the economy as the autobahn neared Pfungstadt; rather there was a slow, almost Imperceptable, gathering of momentum. Workers who had not seen regular paychecks in some time were proud to bring home money which they had earned than their welfare checks. 14 In the political sector life did not seem as if it would ever be normal again to the workers. Several SPD leaders expressed the notion that they would not outlive the Nazi state. Politics was the last thing they had on their minds. ${ }^{15}$ But a political system surrounded them and their neighbors in Ffungstadt. The Nazis saw to thatp The SA had a particularly significant part to play in the Nazi plan for Pfungstadt. Since they were by far the largest group (estimates of the size of the SA range from seven hundred and fifty to one thousand $s 1 x$ hundred ${ }^{16}$ ) under the direct control of the NSDAP and they represented 
more classes of people than any other organization, spectal emphasis was laid to SA events. Special meetings were held In order to set out the politically acceptable party IIne and to make sure that each man knew his responsibility to attend SA functions. On December 3 en exceptional display of horse mounted SA from outside of Pfungstadt put on a show. On December 10 the SA company 143 dedicated a flag w1th full pomp and circumstance. December 13 the SA laid speclal emphasis upon "all German people" seelng the film SA-Mann Brand. On December 17 the SA collected money for the Winterhflfe. Each ten pfennig donation brought with it a badge for the contributor. One hundred and sixty-six marks were donated. On December 18 the SA held a Christmas party complete with a tree and songs. ${ }^{17}$ The activities of the SA varled under the leadersh1p of obersturmführer Homburg; the goal of completely integrating the workers Into the Nazi state did not change. Desplte the favorable Impression Homburg made on the average member (he gained an enviable reputation for his fairness and opposition to excessive drinking) he toed the line as to party disc1pline. 18 When orders did not keep someone in line, meaningful threats were employed. No one had forgotten that Ostho in was less than an hours drive from Pfungstadt. Physical force still lay at the base of the Nazi hold on Pfungstadt. Threats did not have to be enunclated each day. An article in the Anzelger, a rumor from a friend 
were enough to keep almost everyone in line. While threats provided the disclpline, there were very few wholehearted working class converts to the Nazl state. ${ }^{19}$ A man bore his burden without saying much of anything, content at times that he had been lucky enough to find work on the autobahn and stay clear of the authorities. The mass of the working class st1ll clung to their old traditional notions, but not openly, only with the most intimate of long-time friends were words of deflance hurled at the new masters.

Spreading out from the body of the Nazi party were the tentacles of control--the organization, clubs, associations which were directly or Indirectly linked to the party. The farmers were as much a part of the Naz1 network as any other group. The1r leader was the Nazi Heinrich May. May had acquired a name for himself from the role he had had in supressing the workers on March 7 with a contingent of his farming colleagues. Many people, behind his back, sald that he had a mean disposition. A more fanatical Nazi would have been hard to find in Pfungstadt. 20 May was the driving force behind the organization of the nationally propagandized Erntedankfest (Thanksgiving) in Pfungstadt. At a special meeting of the Bauernbund, May pledged to the farmers that the Erntedankfest would rival the National Day of Work is size. A large announcement in the Anze1ger declared that the Erntedankfest was to show 
the ties between the town and the land. Everyone was ordered to attend. 21 The list of events included:

$6: 30$ A.M. Songs by the SA band to wake everyone up 7:45-8:00 Dr. Goebbels' speech on the rad10

9:30 Thanksgiving church services

11-12:00 Concert at the town hall

2:00 Parade

5-7:00 Retransmission of Hitler's speech in virtually every restaurant and hall in the town

The punctuality that had Impressed everyone so much on May 1 was missing from the festivities on October 1. The parade started a full forty-flve minutes late. Wagons decorated in various motifs were strategically placed throughout the parade to separate the mounted $S A$ from the NSDAP members and so on. The farmers were divided by the crop or animal they speclalized in raising. At the end of the parade came the SA. Mayor Steinmetz and Bauernführer May each spoke at the town hall when the parade came to an end, thanking God that He had given the German farmer Adolf Hitler. The Horst Wessel song came at the conclusion of the speeches. After listening to Hitler speak on the radio the large crowds adjurned to various restaurants where dances began. 22 Pfungstadt had never seen anythlng like the Erntedankfest before. The farmers had never been singled out for special attention in such a way. While the crowds were not quite as large as those that had par- 
ticlpated in the May I events, the distinct impression uppermost in many minds was that Hitler really cared for the farmer and the German people. Many people went away from the festivities a little more convinced of the righteousness of the Naz1 cause. In others it made the Naz1 control of Pfungstadt seem just a little more complete. May 1 had been set aside for the workers, October $I$ for the farmers, October 15 was to be a day for the craftsmen. Again there was the SA to awaken everyone early in the morning, again there was the church service, again the concert at the town hall and again the parade. Only a speech by Hitler was missing from the carbon copy of previous "Days." The Anzelger once more reported the inevitable success of the event. Adolf Hitler was again characterized as having saved "German craftsmanship" from ruin in the paper. 23 some people began to grow tired of the constant stream of parades, celebrations, and festivities. 24 But if some people were worn out from celebrating they were not members of the NSDAP.

Autumn brought with it the Nationalsozialistische Volkswohlfahrt (National soclalist welfare organization). The NS Volkswohlfahrt introduced the people of Pfungstadt to a new dimension in organized collections. The Nazis pushed the program to seek a contribution for the poor and needy from everyone. Special Sundays were set aside for the SA, the NS Women, the HJ and Bdor others to gather 
funds. Those who contributed recelved a button they were to display "so as to remind everyone to g1ve"25 and also tc make 1t easy for the collection gatherings to 1dentify anyone who was attempting to avold glving. Also in the master plan for squeezing money out of the people was a most peculiar invention--the Elntopfsonntag. Basically the idea was for the woman of the house to use only one pot to cook the family's Sunday meal and contribute the amount that the family saved over a regular Sunday dinner to the Volkswohlfahrt. To see that people observed the practice SA men who went house to house collecting the money which had been saved also often stuck thelr heads into the kitchen. 26 Ironicaliy many people in Pfungstadt had to make do with Elntopf meals every day of the week. Four hundred and elghty marks was contributed on November 5, the flrst of several Elntopfsonntagen to come. Farmers were informed that they too would be expected to give a small portion of their crops to the Volkswohlfahrt; many did not like the 1dea. 27

Driven by the Nazis from one celebration or event to another, the average man in Pfungstadt could not 1magIne what was to happen next. On october 25 they found out, for on October 25 the first in a series of "election" rallies was held in order to stir up enthuslasm for the November 12 Relchstag "balloting." On October 25 the NSDAP presented a "Rally for freedom and equal rights." 
Actually it was three separate rallies on the same night. At one restaurant Ortsgruppenle1ter Gräf and the SA man Stumpp (Neu Isenburg) spoke to the crowd. At another hall Mayor Stelnmetz and Krelsle1ter Zürtz evaluated the electIon, while at st1ll a third point Gräff's second in command Georg Rlehl and Gaupropagandalelter Treffz lectured at the gathering on the value of Nazism. ${ }^{28}$ The Nazls had begun to prepare the people for "voting" on November 12. Supplementing the effort of the NSDAP in Prungstadt were events in surrounding towns. Of distinct Importance was the speech of Hitler on October 29 for which a special train was arranged at minimal cost to interested parties. ${ }^{29}$ For those who could not attend, the speech was carrled over the radio. Another feature of the Naz1 campalgn to win the support of the people of Pfungstadt was advertisements placed in the Anzeiger. One such propaganda plece urged "Whoever loves his people and his fatherland, whoever hates war and the armaments race In Europe--he should vote 'yes' on November 12." Another contained the reputed words of Hitler to the effect, "We know only one goal on this world: not hatred of other people but the love of the German Nation!" 30 The Nazis drove themselves nearly to a state of exhaustion before the "election" as they prepared one activity after another for the people. On November 8 the Nazis notifled the populace that "all people must attend" the rally of the 
NSDAP scheduled for that evening. The SA was out early to see that the people followed the dictates of the party. The halls were packed. 31 on November 10 the party staged a slightly different type rally. Exactly at 1:00 P.M. a siren blew to stop all traffic for one minute. After trafflc returned to normal the rally of the Nazls began at the town hall square. Also included in the festivities were the school chlldren. Mayor Stelnmetz addressed the crowd after they had IIstened to Hitler's speech to the workers at the Slemens factory in Berlin. The school chlldren then entertalned the crowd with songs, poetry and dances. The rally was closed with the Horst Wessel song. 32 The day before the people were to go to the polls the Anzelger ran Naz1 advertisements on four of 1ts elght pages and editorlallzed that November 12 was the day to decide Germany's fate. Complicated arguments were dropped; $a$ simple approach was adopted. The people were told, "Vote 'yes', 1t is your duty."33 The NS Volkswohlfahrt did Its part to stir up the people by distributing the first of Its gifts to the poor and needy the day before the "vote." 34 One might have actually belleved that the Nazls had had an opponent in the campaign for votes, if one had fudged the strength of the opposition on the energy the Naz1s expanded. There was no opponent and there was no real election. The "voting" was somewhat complicated since the people were actually "approving" a l1st of Naz1 cand1- 
dates for the Relchstag and were endorsing Hitler's actions with regard to the League of Nations. * According to the Nea1s, who counted the ballots, $98.31 \%$ of the electorate:: went to the polis and $97.44 \%$ of the peopie approved Hitler's foreign policy activity while $93.77 \%$ agreed to the I1st of Nazl candidates. The complete falseness of the election was noticed by some who noted that the Nazis had reported that $92.77 \%$ or the inmates of the Osthofen concentration camp had agreed with Hitler's taking Germany out of the League of Nations and $90.80 \%$ had voted for the NSDAP list of candidates. 35 The election was quite obviously rigged.

Rigged or not the people of Pfungstadt undoubtedly voted overwhelmingly for the NSDAP and Hitler. Many citizens went so far as to write their names conspicuously across their ballots before they turned them 1 . ${ }^{36}$ The small amount of opposition that was still left in the workers found 1ts expression at the polls. In the workIng class sections of Pfungstadt nearly ten percent of the vote was against the Nazis. People who did "vote" got a button for their efforts to wear throughout the day. Few people were foolish enough to ohallenge the NSDAP by abstaining from the election. Only four percent of the voters in the predominately middle class/farmer sections of "In October, 1933, Hitier withdrew the German Reich from the League of Nations. 
Pfungstadt votes against the Nazis. The exact returns for Pfungstadt as a whole were:

hESULTS OF THE NOVEMBER 12, 1933 ELECTION AND PLEBISCITE Reichstag election Plebiscite

For the NSDAP 4,786

Yes 4,866

$(97.44 \%)$

Against the NSDAP

$$
\frac{315}{5,104}
$$

$(6.23 \%)$ No

156

5,115

Realizing that a portion of the working class still tenaciously clung to the right of opposition publically, Ortsgruppenle1ter vowed to bring them into the Nazi system. On October 19 three people had been taken to Osthofen for disrespectful remarks about the Naz1 process of government in Pfungstadt. Gräf and other Nazis vowed they would again send people to Osthofen if the opposition showed its face in Pfungstadt. 37 The valiant display of opposition on November 12 was to be turned agalnst the workers. One form of Nazl action agalnst the "marxists" had been to drive them into Nazi controlled clubs. When it seemed as if an inordinate number of SPD members had folned the Germanla soccer club after the dissolution of thelr own group the Naz1s ordered that anyone jolning after March 5, 1933, could only be consldered a guest. By October the Germania club was openly belng attacked for having "too many former 'marxists' In the club." The Naz1s openly talked of dissolving the Germanla. 38 There was to be no way to separate oneself from the Naz1 state, the Naz1 1deology, the Naz1 
threats. The Protestant youth group in Pfungstadt learned that lesson late in December when 1t was announced that its me nbers wore henceforth members of the H1tler Jugend. 39 Even the Handwerker und Gewerbeverein; which had supplied the Nazis with any number of party members and whose ranks generally stood solldly behind the Naz1s, was not spared. On December 22 they learned that their group had been dissolved and that they should apply for membership in the employees arm of the Work Front. 40 No one would be able to escape the Nazis.

In front of the town hall during the Christmas season stood a large Christmas tree, representing, the Nazis sald, the spirit of Christmas they had installed. ${ }^{41}$ The system that they had really installed had little to do w1th the spirit of love that is traditionaliy attached to that per10d. The Nazis were the masters, the people were merely the tools at the disposal of the party. No criticlsm of the basic structure of the Naz1 state was broached, no opposition, however minute, was accepted. No real freedom existed in Pfungstadt by the end of 1933. 
CHAPTER XV - FOOTNOTES

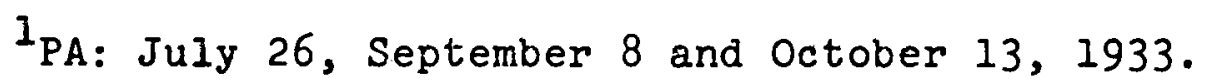

${ }^{2} \mathrm{PA}$ : November 15 and December 13, 1933.

$3_{\mathrm{PA}}$ : November $30,1933$.

${ }^{4} \mathrm{PA}$ : December 19 and 20, 1933.

${ }^{5} \mathrm{PA}:$ December 16, 1933. $415-418$.

${ }^{6}$ PA: October 10, 1933 and PGSP: October 9, 1933, pp.

7PA: November 3, 1933 and PGSP: November 2, 1933, pp. 419-422.

${ }^{8}$ PA: October 10 and $27,1933$.

$9_{\mathrm{PA}}$ : October 18, 1933 and interview with Heinrich Schaffner.

${ }^{10} \mathrm{PA}$ : October $27,1933$.

${ }^{11}$ PA: March 31 and April 4, 1931. There are numerous other examples. 4, 1933.

12 PA: October 13, 14, November 14, 25 and December

${ }^{13}$ Interviews with Karl Emig and Johann Kölsch.

14 Interviews with August Hechler and Peter Cröpmann.

${ }^{15}$ Interviews with August Hechler and Georg Liebig.

${ }^{16}$ Interviews with Wilhelm Kaffenberger, Heinrich Schaffner, Johann Kölsch, Karl Emig, Jacob Delp and Georg Liebig.

${ }^{17} \mathrm{PA}$ : November 8, December 2, 9, 11,13 and $18,1933$. 
${ }^{18}$ Interviews with Jacob Hanbuch, Heinrich Schaffner, and Georg Llebig.

${ }^{19}$ Interviews with Jacob Delp, Georg Herth, August Hechler, Peter Crößmann and Johann Kölsch.

${ }^{20} \mathrm{PA}$ : September 21, 26, 27 and 29, 1933.

${ }^{21} \mathrm{PA}$ : September 30, 1933. Special preparations were made for Hitler's speech and special notice given that "coming and going during the retransmission is not desired so that everyone can listen to the Führer without belng disturbed."

${ }^{22} \mathrm{PA}$ : October 2 and 3, 1933.

${ }^{23} \mathrm{PA}$ : October 10, 11, 13, 14, 16, 18, and 20, 1933.

24 Interviews with Ludwig Wenz and Ludwig Gunkel.

${ }^{25} \mathrm{PA}$ : September 19 and October 8 and 31, 1933.

${ }^{26}$ PA : November 4, 1933.

27 Interviews with Maria Schulz and Jacob Hanbuch.

${ }^{28}$ PA: October $24,25,26$ and $27,1933$.

${ }^{29} \mathrm{PA}$ : October $27,1933$.

${ }^{30} \mathrm{PA}$ : October $20,24,30$, November 7 and $8,1933$.

${ }^{31} \mathrm{PA}$ : November 7,8 and 9, 1933.

${ }^{32} \mathrm{PA}$ : November 9 and $11,1933$.

${ }^{33} \mathrm{PA}$ : November 11, 1933.

$34 \mathrm{PA}$ : November 10 and $11,1933$.

${ }^{35}$ PA : November 13, 1933. 
${ }^{36}$ Interviews with Helnrich Sand, Jacob Delp and Peter Crößmann.

37 PA: October 19, 1933.

${ }^{38} \mathrm{PA}$ : October 18 and $20,1933$.

${ }^{39}$ PA: December 23, 1933.

${ }^{40}$ PA: December 22, 1933.

${ }^{41} \mathrm{PA}$ : December 20, 1933. 
CHAPTER XVI

\section{NAZI PFUNGSTADT - 1934}

Contrasting the New Year of 1934 with the New Year of 1933, the people of Pfungstadt not1ced that profound changes had occurred. In the place of an unknown polftical future (In January, 1933), the relgn of the Nazis seemed secure from attack in 1934. The undeclded factors wh1ch had existed at the beginning of 1933 had all vanished; the Nazis had replaced indecision with orders, threats, rallies, clubs and the party itself. Gone was a town council of opposing vlewpolnts, gone were the clubs and groups of which the SPD had been so proud, gone also was the right to freedom of speech, assembly, press and political preference. Nothing stood outside of the Nazi state, neither man, woman nor child.

The Nazis constantly reminded the people that the NSDAP was the entrenched authority in Pfungstadt. On January 30 the party sponsored a celebration of the first anniversary of Hitler's appointment to the chancellorship of Germanj. Early in the morning of the thirtleth the school children and thelr teachers held a formal commemoration of the event; the NSDAP itself staged a large rally at the town hall. The mayor of Darmstadt, Lang, spoke to 
the crowd along with Mayor Steinmetz and Ortsgruppenlelter Gräff. The messages of all three men were essentially the same: "Forward with our Funrer for the German people and the fatherland." The same evening the NSDAP held a membership meeting at which songs were sung, speeches were made and history distorted. The meeting closed with the words: "We begin the second year knowing that our task had not been completed, but with the firm conviction that our task now will be finished if we are always true to the Führer. He will lead us to our goal."l

In 1933 the Nazis had presented every conceivable commemorative day to the public--some thought; in 1934 the Nazis used many more opportunities to drive their thoughts home. On February 26 the party honored the "hero" Christian CröBmann. The first anniversary of his death was a chance for the party and the school to lead the children of Pfungstadt closer to Nazism. A number of speeches preceded the unvelling of a special memorial gravestone in the cemetary. The children were told to follow in the footsteps of Crößmann for the good of the Reich. ${ }^{2}$

April 1 brought with it a rally for the people in the Saarland. The cltizens were again directed to attend the festivities which were planned for the town hall square. On that day over fifteen hundred people took part in the Nazis' design. ${ }^{3}$ The toplc for celebration had changed, the means to carry it out had not. 
Hitler's birthday, on April 20, was the occasion for the Nazis to exhort the people to assemble once again. Orders went out for each homeowner to put out his flags. The NSDAP sponsored the showing of the film "hans Westmar" based on the book Horst Wessel by Hanns-HeInz Evers. The SA band played several tunes before Ortsgruppenle1ter Gräff delivered his speech. The SA gathered in several restaurants throughout Pfungstadt to celebrate the birthday of Hitler over a glass of beer."

May 1 received the full attention of the Nazls as it had the previous year. A more prominent part was played by the Hitler Jugend in the festivities; the whole morning was devoted to various events for their pleasure. At 2:00 P.M. an impressively long parade, divided by occupations, rolled to life. Mayor Stelnmetz and Naz1 Union leader Fritz Gunkel (no relation to Ludwig Gunkel) responded to the occasion with long speeches. A part of the day's activities were set aside for the presentation of a plaque for forty years service to a brewry worker. As with other affairs Hitler was given complete credit for all of the achievements of the past year and for saving the "German worker" from the cluching grasp of the "reds;" their "opportunistic bosses" the union leaders. 5 A cult about the goodness, the justice, the farsightedness and the power of Hitler grew perceptively. At every event the Nazis hammered home the notion that the people had Hitler 
alone to thank for all of life's pleasures. The freshness of some of the Nazis' gains was dulled in the minds of many by the superhuman treatment and regard the Nazis showed for their Führer. The same sort of thing, with regard to the local leaders, did not occur. Steinmetz, Gräf and Martin always gave the credit for their achlevements to Hitler, rarely did they try and capture some of the spotlight. ${ }^{6}$ The precocious twins, steinmetz and Martin, had found their master in the Führer.

The pace of the Nazis did not diminish as Spring gave way to summer. Work on the autobahn continued, more men found jobs bullding 1t. Slowly the economic rate of recovery speeded up. Late in July the houses in the Seehelmer settlement were finished. With great fanfare the new occupants moved in. ${ }^{7}$ The town's expenditure for the unemployed sank to less than two thousand marks per week and the businessmen reported a noticable pickup in their business. Life had assumed a different, but not altogether unpleasant appearance. The Nazis did everything in their power to cultivate 1dea.

The NSDAP continued to meet on a regular basis once or twice a month. The town was divided into sections by the party for the distribution of information and for meetings. Hans Otto, Wilhelm Sauer and Karl Fey assumed a position somewhat lower than Gräff as the leaders of 
the "cells." 8 Individual "cell" meetings were then called to organize the people even more strictly along Nazi lines. The party functioned more efficently on its redesigned tasis.

The death of Re1chspresident Hindenburg plunged a large section of the populace into mourning. A series of memorial services were held, directed by the Nazis. ${ }^{9}$ In addition, a few days later, plans for a plebiscite were announced. The people were to "decide" if Hitler's assumption of the presidency met with their approval. Full page advertisements sprouted in the pages of the Anzeiger on August 1.4 and ran every day until the plebiscite on August 19. The NSDAF scheduled only one mass rally before the "decision" of the people was called for. ${ }^{10}$ To the misic of the SA and Jungrolk bands the people went to the polls; over seventy percent "voted" before noon, the rest were reminded of their duty to vote by the SA, HJ and Jungvolk. The "skill" of the Nazis to turn out the vote was revealed the following day when the election returns were printed in the paper. Nearly ninety-eight percent of the eligible voters had cast thelr: ballot, $93.8 \%$ were marked yes and $6.2 \%$ were marked no, according to the Nazis. ${ }^{11}$ Pfungstadt's Nazis were proud to boast that their percentage of "yes" votes was above the average reported in the Relch, in Hesse-Darmstadt and in the county of Darmstadt. 
But in one working class district of Pfungstadt over thirteen percent of the vote was no, despite the obviously minaged "election." 12

The predictable result of a thirteen percent "no" vote being reported was Nazi anger. The Anzelger printed an article attacking grumblers and alarmists; they would be punished warned the paper. The Anzeiger also announced that "protective custody" detention meant certain loss of one's job. 13 Life would be made very unpleasant for anyone who made his opposition to the Nazis too public.

To speak of a public opposition to the Nazis in 1934 is nonsense. There was no public opposition nor was there likely to be any. Private opposition was limlted to Individuals, not groups. Few people had friends loyal enough to be entrusted with the full extent of a man's private thoughts about the Nazis. ${ }^{14}$ The Nazis, for their part, carefull nurtured activities for non-party members anyone could take part in. The NS Volkswohlfahrt fell into that catagory. The donations to the NSV went to the needy; few men refused to give to the cause even if it was run by the Naz1s. The collections for the poor began in october, 1933 and continued until the beginning of March, 1934. The Nazis became adroit at involving the people in the process by consplcious displays of the food and goods collected at the town hall before they were distrlbuted. They also had 
contributors wear a badge. C1tizens who had not given were easy to identify and corral for the next collection. Even when the period for collections had come to an offlclal end in Pfungstadt, Martin, the chairman of the NSV, ingenfously though of a way to gather more funds--he staged a day in rememberance of varlous collections, a Day in Rememberance of the Eintopfsonntag, a Day in Rememberance of the HJ Collection and so forth. 15 The process had unlimited possiblifties.

Behind the direct pressure on the people to accomodate themselves to the Nazi administration were inner forces which worked on a man or woman to tacitly accept the Nazi state. People were constantly reminded that, "Hitler is making work for everyone." 16 From every side, from every part of a person's day, the Nazls shouted, sung, described, displayed, paraded, pictured and wrote of thelr accomplishments. The physlcal means of repression which were at the disposal of the Nazis were held as a reserve. The Nazi film "Sleg des Glaubens" provided the Nazis with an example of an effective propaganda weapon. 17 There was nowhere one could escape the public pronouncement of the Nazis, even the privacy of one's home was not sacred if one was in any way suspected of critizing the party. At one time the chlldren of the school viere instructed to notify the authorities if their parents sald anything uncomplimentary about the NSDAP. 18 
Refining their stranglehold over the political process in Pfungstadt was a full time task for the Nazis, one they engaged in with ferver and determination. As new clubs were formed they staked out a position of dominance. A meeting of former navy members, something that had not taken place in Pfungstadt since World War $I$, occurred in June. ${ }^{19}$ Other branches of the service recelved similar attention. The Krieger- u. Militärvereln became an 1mportand link in the Naz1 leash on Pfungstadt. There was simply no escape, no way out of Nazi control.

. The year after the Nazl selzure of power was a very difficult time for former SPD, KPD and Associated Union leaders. There was no work for them, there were no supplements for their nonexistant incomes. No one was eager to publically help them out. In private a few members of the working class communty did support their old leaders as best they could. 20 , But the risk to those people was very great since exposure of their activities placed them In line for some sort of Nazl reprisal. The former leaders 11ved, but without hope and without confidence in the future.

The Nazi propaganda machine, which Mayor Stelnmetz headed in addition to his other duties, ground on. There were preparations made, at the insistence of the Nazis, for alr rald shelters and practice with gas masks. 21 There were swimming contests for the HJ, BdM and Jungvolk. The 
Kraft durch Freude sponsored several activities for the cltizens of Pfungstadt. There was a German Rose Day, Memorlal Day, German Volkstums Day, Thanksgiving: Day (Erntedankfest) and others. ${ }^{22}$ A celebration took place on November 28 for the Day in Rememberance of Nationalsoz1alistische Gemelnschaft, the first anniversary of the establishment of the Kraft durch Freude unit in Pfungstadt. on December 7 a Day of Nat1onal Solidarity was staged. 23 But the Nazis had only succeeded in creating a solidarity based on the bürgerlich around which a thin veneer of workers moved. The working class of Pfungstadt did not oppose the Naz1s, but the cooperation on the part of the workers was based on a pragmatlc reading of the balance of power. The velied threat, the Informer and Osthofen-they were essential if the Nazls were to stay in full control.

The perlod of history through which the people of Pfungstadt were l1ving created 1ts own kind of respectable man. Many of the Naz1s sincerely belleved in their cause and the means by whlch they had set about to reach their goals. There were Nazls who trled to achleve the best of all possible worlds. But outwelghing these men were the people who were swept along with the tide, who had not known where they were leading themselves and the town before 1933 and did not see any more clearly after 1933. There were 1dealistic Nazis, there were vengeful Naz1s, 
there were respectable Nazis and there were desplcable Nazis--Pfungstadt's great loss was that there were too many Nazis. 


\section{CHAPTER XVI - FOOTNOTES}

${ }^{1}$ PA: January $24,26,29,30$ and 31,1934

${ }^{2}$ PA: January 23, 24, 26 and 27, 1934.

${ }^{3} \mathrm{PA}$ : March 29, 31 and Apr11 3, 1934.

${ }^{4} \mathrm{PA}:$ Apr11 16, 19 and 21, 1934.

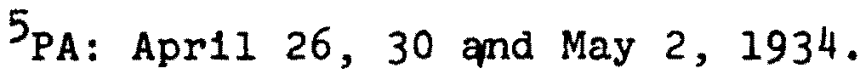

${ }^{6}$ Interviews with Heinrich Sand, Heinrich Schaffner, Wilhelm Kaffenberger and Jacob Hanbuch.

$7_{\text {PA: March }} 28$ and July 21, 1934

${ }^{8} \mathrm{PA}:$ March 13, 23, 26, May 8 and 16, 1934.

${ }^{9} \mathrm{PA}$ : August 6 and 8: 1934.

${ }^{10} \mathrm{PA}$ : August 14,16 and $17,1934$.

${ }^{11}$ PA: August 20, 1934.

${ }^{12}$ Ib1d.

${ }^{13}$ PA: January 18 and May 24, 1934.

${ }^{14}$ Interviews with Fritz Feldmann, Jacob Delp and Maria Schulz.

${ }^{15}$ PA: February 2, 10, 14, March 7, 10, 17, Apr11 6 and 10, 1934.

${ }^{16}$ PA : February 22, 1934.

17 PA: January 18, 26 and $27,1934$.

${ }^{18}$ Interview with Jullus Winkler. 
${ }^{19}$ PA: June 6, 1934.

${ }^{20}$ Interviews with Peter Crößmann, August Hechler and Johann Kölsch.

${ }^{21}$ PA: January 24, May 15, June 5, October 23 and November 14, 1934.

22 PA: January 19, February 27, April 13, May 14, July 16, August 8 and September 19, 1934.

${ }^{23} \mathrm{PA}$ : November 28 and December $7,1934$. 
CHAPTER XVII

AN ASSESSMENT

"Jeder bleibt so in selnem Kreis, nur die Augen nicht aufmachen was drüben passiert." 1 The years after 1934 were filled with trials, tribulations, and closed eyes. Trained to obey the1r masters during the 1933-1934, the people of Pfungstadt were powerless to halt the march of Naz1 history. The Nazl party remalned the one almighty force in the town; the Nazls went on about their business, the people particlpated when told to do so. For many it was a time of calm and moderate prosperity. A few reflected on the price that was being demanded.

Naz1 controls were complete, but not altogether stifling for the many men and women who did not question thelr signiflcance. The average man generally belleved that he was living in a decent, if not outstanding, time. Economic expansion continued, many construction companies received a share of various bullding projects throughout Germany. An ammunition dump was bullt to the east of Pfungstadi, employing many men; others found work in Pfungstadt or in nearby towns as they had before the depression. 2

Mayor Steinmetz retired from his position as head 
of the town's administration in 1935, turning over the reins of command to Georg Rlehl, Ortsgruppenlelter Gräff's second in command. Stelnme $z$ became vice-mayor along with Martin. The council met less and less often until in 1939 only one session was conviened the entire year. ${ }^{3}$

An anti-religious campaign of sorts broke out when it became apparent that the Protestant minister strack was an ant1-Nazi. (Strack had replaced Minister Zinn in November, 1933 when $Z$ inn retired.) SA men were stat1oned in front of the church on Sundays, dutifully writIng down the names of each individual as they entered the service. 4 Kristalnacht (1938) brought out the very worst of the Nazis to burn the town's very small synagogue to the ground, ransack several Jewish iblinesses (the furniture from one store was thrown in the Modau) and beat up many a Jewish inhabitant of Pfungstadt. All of Pfungstadt's clubs were consolidated into one large unit late in 1939.5 The terror of the Nazis was very real; they did not lose sight of their goal for a moment.

Just before the war broke out three citizens of Pfungstadt were sent to the concentration camp at Dachau. The reasons they were sent are not clear. ${ }^{6}$ The war depleted the town of its young and so young able bodled men. The only real damage suffered by Pfungstadt during the war

547 people from Pfungstadt were k1lled in WW II. 
came as Allied bombs: struck the city of Darmstadt in 1944. A few stray bombs hit the working class section of the town destroying the post office. Ortsgruppenle1ter Grāff was killed in Darmstadt during those same Allied raids. ${ }^{7}$ The town faced the advancing American army almost defenseless. A few tank traps were dug to the west of the town and the old men and very young boys enrolled in a militia. But Pfungstadt was spared the destruction resistance to the Americans would surely have purchased when on March 23, 1945 Ludwig Clemenz (Albert Wälke's assistant In the Reichsbanner) took a white sheet from his home and bravely marched in the direction of Eschollbrücken to meet the Americans. The town was surrendered. Shortly thereafter clemenz was named by the commanding officer of the Americans who were occupying Pfungstadt to the post of provisional Mayor. A Bürgerrat, composed of former SPD and KPD members, soon followed. Clemenz never saw the dramatic changes which came to Pfungstadt after the war since he died of blood polsioning on August 15, 1945. Another SPD man, Georg Roth, was named to replace him. 8 The transition from the Nazi state to American control and then self-administration was carried out swiftly, although not without blood flowing. Former Mayor Steinmetz was captured as he tried to secretly reenter the city, taken to the town hall and severely beaten--he hung himself. Other Nazis were not driven to such drastic extremes, but 
recelve physical punishment for their participation in the Third Reich. 9

The population of Pfungstadt reached nine thousand as the war drew to an end (1939: 7,959) and increased to over ten thousand in 1947 as a steady stream of refugees found thelr way to the town. By 1970 the total population of the town was over seventeen thousand. ${ }^{10}$ Recovery from the war was rather slow until after 1948, then Pfungstadt began an economic serge that has created the most stable economic development Pfungstadt ever experienced. The golden days of the $1850^{\prime} \mathrm{s}, 60^{\prime} \mathrm{s}$ and $70^{\prime} \mathrm{s}$, long since forGotten, were far surpassed. For Pfungstadt the 1950's, 60 's and 70's have become a golden age economically. PoIitically the SPD has dominated the town, first in cooperation with the KPD and then alone after the KPD was banned. (Interestingly enough, the SPD today receives an average of about sixty percent of the vote, compared with the combined SPD/KPD average of just under sixty percent before 1933.)

Pfungstadt's Nazis found the move into the Bundesrepublik difficult, their sons and daughters did not. Democracy has established a strong and vital base in the town. There is little talk of the "good old days" when Hitier was in power, except among the very old. The democratic forces contol the town. Did they learn a lesson from the perlod 1928 to 1935, the years in which the pop- 
ulace fought its $11 \mathrm{fe}$ and death struggle?

The single most 1mportant reason for the triumph of Nazism was the division of the town along strict class IInes. The rare instances of class cooperation, as in the pre-1929 town council, were far outweighed by a not-toosubtle demarcation line between der Arbeltgeber and der Arbeltnehmer. The ownership of a business seemed to confer a badge of distinction on the person which the burgerI1ch took very serlously. Not every member of the middle class was afflicted with this malady, but a very large number definitely were. The middle class called Pfungstadt "elne rote Hochburg" (a red stronghold) before 1933. ${ }^{11}$. The nalve assumption of the middle class that the cholce was Naz1sm and Communism led the bürgerlich blindly to the Nazis. Compromise with the "reds" was impossible in the minds of the middle class. The strange hatred of the SPD and the KPD was not directed toward individual members of those groups, but toward the organization 1tself. The myth of the workers power nurtured the hatred of the middle class. The Nazis entered the picture, in part, because of this paranold position of the bürgerlich. The traditions and prejudices handed to them by their own parents had much to do with their stand. It is difficult to believe that the nature of the SPD had much to do with the plight of the middle class. The middle class members of Pfungstadt's soclety who dared to stick out their hand to 
the SPD were warmly welcomed. The SPD had shown an amazIng degree of restraint in the town counc1l during the twentles and Georg Raab stood as an example of the best of the SPD--a man of the people who worked for the people, even the middle class respected him. The trouble of the middle class lay deeper; somewhere in the middle class soclal and polftical values which were inherlted from the time of Imperlal Germany and the Welmar Republic lies the answer. The blame for the Naz1 trlumph in Pfungstadt lies with the bürgerlich, not with the workers.

The depression distorted the thinking of most of the people. Everyone demanded change, any change, as long as some solution was found. Under the Influence of a depression mentality, both the middle class and the workers moved toward the extremes. The middle class to the Naz1s and a sizable portion of the workers to the KPD. Change was the order of the day, any change. The depression threw a blanket of blindness over the people. Only the SPD kept its head. But the SPD was in no position to lead lgnorant men back to reality. The bridges of understanding to the middle class had been burnt by the bürger$11 \mathrm{ch}$ and the KPD was steadily bullding a following out of SPD members who thought that the SPD was not radical enough. To accommodate the demands of the middle class would have been polftical sulc1de, for the KPD would sure- 
ly have captured most of the SPD voters. Besides, the SPD would never have been accepted by the bürgerlich. Tre chlef effect of the depression was to magnify the unstable political conditions which had existed even before the economic slump set in. Political senselessness increased in direct proportion to the growth of the depression. Tension mounted, the search for any solution grew more hectic. Those tensions, fears and frustrations were the base upon which the Nazis built their political power. The old traditional middle class parties of Pfungstadt (the DVP, DDP and Landbund) were no match for their greatest challenge. While the SPD searched for a way to finance work projects for the unemployed, the traditional middle class parties were opening the door for the Nazis. A heavy amount of blame must fall on the leaders of the middle class parties; they falled to ignite the spirit of the middle class for ordered change; they falled to hold thelr own traditions high; they falled to find a man of Wilhelm Büchner's stature in their time of trial. If any two men came close to matching the appeal that Büchner had exuded than they were Georg Stelnmetz and W1lhelm Martin. They became the spokesinen of the bürgerlich in the town counc1l, blocking the work projects they were later to institute. They pandered to the wants of the middle class under the label of "non'political" politics; they led the midale class away from their real traditions toward some- 
thing no one understood. Upon their shoulders lies a grlevous guilt. They helped erect a frame of mind perfectly sulted to the NazI jians. They destroyed the cohesion that Pfungstadt's soclety of people so desperately needed. Where Christoph Hanbuch (DDP), chalrman of the town's finance committee in spite of his party's minimal political Influence, had stood in the twenties, Stelnmetz and Martin stood in the thirties. The difference was profound.

The actual selzure of power by the Nazis on March 7, 1933, did not require large numbers of people. A moderate number of well armed men from Pfungstadt, supplemented by Darmstadt SA men, sufficed. To consolidate their author1ty the Nazis relled heavily upon the middle class. The workers would have no part in the Nazl plans. The soclal division of the town played a significant role even in March, 1933. The SPD had prepared 1tself for a struggle under the leadership of Interlor Minister Leuschner's po11ce. When Leuschner's forces surrendered to the Nazis the workers were left defenseless, at the mercy of the Naz1s who did not bungle thelr opportunity for control. Once physical control of Pfungstadt was clearly in Nazi hands the bürgerlich streamed into the party, eager to regain power from the "reds."

When Stelnmetz became mayor and Martin vice-mayor In Apr1I, 1933, the c1rcle was complete. W1th the whole- 
hearted support of the new leaders of the middle class the Naz1s began the process of integrating Pfungstadt into thelr orb1t. The constant parades, marches, memorlal days and charity drives served to draw supporters quickly to the party. May 1, 1933 was a very important day for the Naz1s, the workers were led Into the fold unable to offer any resistance. Most workers were unhappy w1th the Naz1 victory; nearly all resigned themselves to the Naz1 controls. Cold blooded political terror played a substantial part in the Nazi triumph: first in the days of March when an unlimited number of searches, arrests and trips to Osthofen convinced any doubters that the Nazls meant bus1ness and secondly in August when the defenseless SPD, KPD and Associated Union leaders were systematically beaten by a vengeful band of $S A$ men. It did not seem to be hard for the fanatics among the NSDAP to ruthlessly inflict pain upon their neighbors.

As the dictatorship of the Nazis grew more mature Its face slowly changed. Securely in power, the Nazis found theinselves, at times, at odds with each other. The idealists against the zealots. For the 1dealistic Nazis many of the events after 1933 were repugnant. For the zealots it was only the beginning. The fanaticlsm which had simmered below the surface of Nazism assumed a new dimension with the outbreak of World War II. No one, not Nazl or non-Naz1, was then safe from an informer. The true 
face of Nazism only fully was revealed to a deluded middle class with the advent of the war. Even then there were many who olamed something or someone else.

Every one of the c1tizers of Pfungstadt was in one way or another affected by the Nazis. Some did not suffer, many did. The war taught many a high-priced lesson, some will never learn. No one will ever forget.

No one foresaw the consequences of their actions in the years before the Nazis grabbed the levers of power. That is by far the most significant lesson the people of Prungstadt have to bequeath to history. The SPD and the KPD did not comprehend the utter destruction the Nazis were to bring or they would surely have fought it. The middle class, the backbone of soclety, falled the test much more completely. When the backbone of the bürgerlich first swayed and then broke under the real and imagined welght of the depression and their prefudices, the way for the Nazis was cleared. They led the town blindly toward the brink of destruction, not stopping even once to conslder the implications of their choice. Similar cases of political blindness could occur again--under different names to be sure--but with fatal results of the same magnitude. 


\section{CHAPTER XVII - FOOTNOTES}

${ }^{1}$ Interview with Julius Winkler. Everyone stayed within his circle of friends, not opening his eyes to what happened outslde of 1 t.

${ }^{2}$ Karl Hechler, Pfungstadt vom Beginn des 20. Jahrhunderts bis heute in Pfungstadt Vergangenhelt und Gegenwart, (Trautheim, 1965), p. 67. $478-480$.

${ }^{3} \mathrm{PA}$ : October 31, 1935 and PGSP: June 9, 1939, pp.

${ }^{4}$ Interviews with Peter Crößmann and Heinrich Sand.

${ }^{5}$ Interview w1th Karl Hechler.

6 Notes from the file of Helnrich Huxhorn.

7 Interviews with Marla Schulz and Karl Hechler.

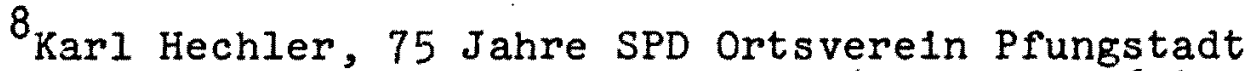
in 75 Jahre SPD Ortsverein Pfungstadt, pp. $51-52$. , 1967),

${ }^{9}$ Interviews with Jacob Delp, Georg Herth, August Hechler and Helnrich Schaffner.

${ }^{10}$ Census records supplied by the present town off1clal Phillip Hanbuch.

IlInterviews with Jullus Hofmann, Gottfried Helene, Heinrich Schaffner, Jacob Brauer and Wilhelm Kaffenberger. 


\section{REFERENCES CITED}

Protokolbuch für den Gemeinderat der Stadt Pfungstadt for $1928,1929,1930,3931,1932,1933,1934,1935$, $1936,1937,1938$ and 1939.

Rechnung über Einhahme und Ausgabe der Geme1nde Pfungstadt for 1928, 1929, $1930, \overline{1931}, 1932, \overline{1933}$ and 1934.

Copy of a letter sent to Justizrat Maetz of Darmstadt concerning the Evangelische Kirche Pfungstadt gegen Gemeinde Pfungstadt, Pfungstadt, 9 Pebruar 1932.

Population statisties supplied by the present town official of Pfungstadit, Phillip Hanbuch.

Notes from the private file of Helnrich Huxhorn.

Notes from the private file of August Hechler.

Notes from the private file of Hans otto.

Pfungstädter Anze1ger, Pfungstadt, West Germany: 1928, $1929,1930,1931,1932,1933$ and 1934.

Hessischer Volksfreund, Darmstadt, West Germany: 1928, 1929, 1930, 1931, 1932 and 1933.

Götz, Willi, Landwirtschaft zwischen gestern und morgan in Pfungstadt Vergangenheit und Gegenwart, Franzmathes Verlag, Trauthe1m: 1965 .

Hablinger, Hans, Die Geschichte der Katholischen Kirchengemeinde in Pfungstadt Vergangenheit und Gegenwart, Franzmathes Verlag, Trauthelm: 1965.

Hechler, Aligust, Die sozlalistische Jugendbewegung in Pfungstadt in 75 Jahre SPD Ortsverein Pfungstadt, HeInrich Koch Verlag, 1967.

Hechler, Karl, Pfungstadt vom Beginn des 20. Jahrhunderts bis heute in Prungstadt Vergangenhe1t und Gegenwart, Franzmathes Verlag, Trauthelm: 1965.

Hechler, Karl, Zur Geschichte der Pfungstadter Volksschule in Pfungstadt Vergangenheit und Gegenwart, Franzmathes Verlag, Trauthelm: 1965. 
Hechler, Karl, 'Zwel Jahrhunderte Pfungstadter Wirtschaft in 75 Jahre SPD Ortsverein Pfungstadt, Heinrich Koch Veriag, 1967 .

Hechler, Karl, 75 Jahre SF Ortivereln Pfungstadt in 75 Jahre SPD Ortsvereln Pfungstadt, Heinrich Koch Verlag, : 1967 .

Knöpp, Frledrich, Die ältesten Pfungstäcter Familien eine bevolkerungsgeschichtliche Betrachtung in Pfungstadt Vergangenhe1t und Gegenwart, Franzmathes Verias, Trautheim: 1965.

Kröpp, Friedrich, Die Geschichte Pfungstadts bis ins 19. Jahrhundert in Pfungstadt Vergangenhe1t lind Gegenwart, Franzmathes Verlag, Trautheim: 1965.

Schuhmacher, Kurt, Das KIIma in Pfungstadt Vergangenhe1t und Gegenwart, Franzmathes Verlag, Trautheim: 1965.

Hessen Im Wandel der letzten hundert Jahre $1860=1960$, Hessischen Statistischen Landesamt, Wiesbaden: 1960.

Pfungstadt, Magistrat der Stadt Pfungstadt, Pfungstadt:

, Yereinsverze1chnis Pfungstadt, Ordnungsamt der Stadt Pfungstadt, Pfungstadt: 1970. 


\section{APPENDTX A}

\section{A DESCRIPTIVE LIST OF INDIVIDUALS INTERVIEWED}

Order of information: age (in 1930), marltal and dependent status, occupation, religious affiliation, party affiliation, voting preferance, newspaper purchased, club affillations and other.

Jacob Brauer

33; married, two children, owner of a construction company; non-practicing Protestant; DVF; DVP; Pfungstäter Anzeiger and Frankfurter Zeitung; Handwerker u. Gewerbeverein, Gymnastics club and Männerquartett.

Jacob Delp

Karl Emig

Fritz Feldmann

Peter Crößmann

Luảwig Gurke?
31; married, no chlldren; stonemason; atheist; KPD; KPD; Pfungstädter Anze1ger and Rote Fahne; Workers soccer cIub and Anti-factst League; fought in world War I.

24; married, one child; carpenter; non-practicing Protestant; SPD until 1932 then the KPD; SPD then KPD; Pfungstädter Anze1ger; Re1chsbanner then the Anti-facist League.

28; marrled, one child; butcher; nonpracticing Protestant; no party affiliation; voted middle-of-the-road nationally and Stelnmetz-Martin locally; Pfungstädter Anzeiger and Darmstädter tágliche Anzelger; gymnastics club.

29; married, one child; bricklayer; nospracticlng Protestant; SPD; SPD; Prungstädter Anzelger and Hessischer Volksfreund; SPD gymnastic club and Relchshariner. Cropmann was the chairman of the Associated Union.

36; married, two chllden; farmer; nonpracticing Protestant; Landbund unt11 1932 then NEDAP; Landbund then NSDAP; Pfungstädter Anzeliger; Harmonie singing club; fought and was wounded in World War I. 
Jacob Hanbuch

Ria Hanbuch

August Hechler

Gottfrled Helene

Georg Herth

Julius Hofmann
27 ; married, two children; carpenter; non-practicing Protestant; no party affiliation unt 1 he jolned the NSDAP In 1929; NSDAP; Pfungstädter Anze1ger.

25, single, Protestant, workered in her father's (Christoph Hanbuch) box factory, no party affiliation, DDP, Pfungstädter Anze1ger.

24, single, metal worker, no religion, SPD, SPD, Pfungstädter Anzeiger and Hessischer Volksfreund, SAJ and Re1chsbanner. Hechler was chalman of the SPD.

26; married, no children; non-pract1cProtestant; editor of the Anzeiger; no party affiliation until Apri1, 1933 then NSDAP; DVP; Darmstädter Tagblatt. Hessischer Volks freund, Frankfurter Ze1tung; Eymnastics cIub.

27; married, one child; athe1st; KPD; KPD; Pfungstädter Anzelger and Rote Fanne; Workers gymnastics club and Ant1facist League. Herth was an offlcial in the KPD and chalrman of its unemployment committee.

38; married, one child; school teacher; Protestant; DVP; DVP; Pfungstädter Anzelger and Darmstäditer Tageblatt; gymnastics clus and Krleger-u. Militärverein; fought in World War I. Hofmarn was the chairman of the DVP.
W1 Ihelm Kaffenberger

Johann Kölsch
33; married, two children; owned a smal1 lumber company; non-practicine Protestant; Pfungstädter Anzelger and Darmstädter tágliche Anzeiger; soccer club; fought in World War I. Kaffenbecame a member of the town council In April, 1933.

39; married, four children; rallway worker; free thinker; no party affiliation; SPD; Prungstädter Anzeiger and Hessischer Volksfreund; Workers gymrasclub and the Associated Union. 
Georg Lieblg

Heinrich Sand
24, single, printer, freethinker, SPD, $S P D$, Pfungstädter Anzelger and Hessischer Volksfreund; SAJ and Re1chsbanner. Liebig was the chalrman of the SAJ for south hesse-Darmstadt.

Adam Ruckelshausen 37; married, two chllaren: co-owner of a small refrigerator factory; nonpracticing Protestant; no party affiliat1on; DVP ther NSDAP; Pfungstadter Anzelger; gymnastics club, fought in World War I. Ruckeishausen was a close personal friend of Georg Steinmetz.

35; married, no children; small businessman; non-practicing Protestant; NSDAP; NSDAP; Prungstädter Anzelger and Darmstädter tägliche Anzelger; soccer club; fought In World War I. Sand Jolned the NSDAP in 1927 and became the party's secretary.

Heinrich Schaffrier 28; married, two children; metal worker; Protestant; NSDAP (joined 1931); NSDAP; Pfungstädter Anzej.ger and Darmstädter tägliche Anzelger; gymnastics club; Joined the SA in 1929.

Luise Steinmetz

Ludwig Wenz

juIfus Winkler

Karl Hech]er
36; married, two chlldren; housewife; Protestant; no party affiliation; DVP then NSDAP; Pfungstädter Anze1ger, Darmstädter tägliche Anzelger. She was the wife or Mayor Steinmetz.

44; marrled, no children; farmer; nonpracticing Protestant; Landbund; Landbund; Pfungstädter Anzeiger and Darmstädter trgliche Anzelger; Harmonie sining club; fought in World War $I$.

34; married, two children; school teacher Protestant; no party afflilation; DDP; Pfungstädter Anze1ger, Hessischer Volksfreund and Frankfurter zeltung; fought in World War I (Iron Cross).

Hechler was born and raised in Pfungstadt but left the town in 1928 to take a taching position. He did not return until 1948. He is Pfungstadt's historian. 
460

APPENDIX B

ELECTION RESULTS ${ }^{1}$

\begin{tabular}{|c|c|c|c|c|c|c|c|c|c|c|c|}
\hline$\frac{\bar{n}}{n i}$ & ฐิ) & $\left.₹\right|_{\sigma} ^{\sim}$ & $\sqrt{2}$ & ज| & $m \mid \begin{array}{c}n \\
m \\
0\end{array}$ & & $m$ & \begin{tabular}{l|l} 
\\
N
\end{tabular} & $\left|\begin{array}{c}m \\
m\end{array}\right|$ & $\frac{0}{3}$ & \\
\hline & $=$ & 赵| & 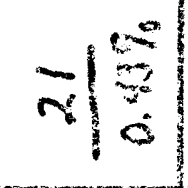 & 路 & $\left.F\right|^{\frac{0}{a}}$ & & $\left.m\right|_{0} ^{\circ}$ & (9) & $\circ \mid$ & $\overline{\bar{a}}$ & 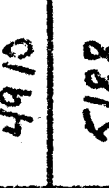 \\
\hline & $9 / 9$ & 915 & $011^{\circ}$ & 인 & $M \mid$ & & $\left.N\right|_{0} ^{\circ}$ & 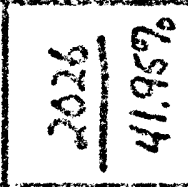 & ㄱ| & 啇 & st \\
\hline & 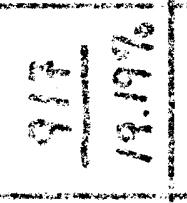 & $\left(\frac{9}{2}||^{\circ}\right.$ & $n 15$ & $\left.b\right|^{\circ}$ & $\left.\infty\right|^{\circ}$ & & 910 & $5 \mid \frac{10}{3}$ & 위잉 & & \\
\hline & $\begin{array}{l}90 \\
9 \\
9\end{array}$ & $\left.5\right|^{\infty}$ & 910 & 舟 & $m / \stackrel{m}{\stackrel{8}{3}}$ & $\because \approx$ & 이융 & 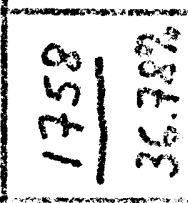 & & 10 & 5 \\
\hline & 9 & 8 & 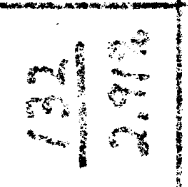 & 퀴항 & 江总 & $m$ & $\left.\Delta\right|^{\infty}$ & $\begin{array}{c}y \\
\infty\end{array}$ & 인 & 19 & 3 \\
\hline & & & & $4=$ & $n \mid$ & 10 & s & : & 到管 & 15 & F \\
\hline & 916 & 8 & 96 & 事 & $\left.m\right|_{0} ^{\circ}$ & 间 & $\left.5\right|^{\circ}$ & & 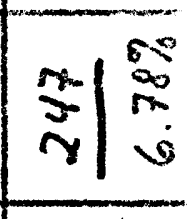 & : & \\
\hline & 6 & 8 & 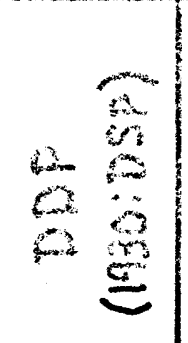 & 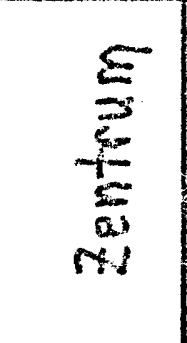 & 3 & 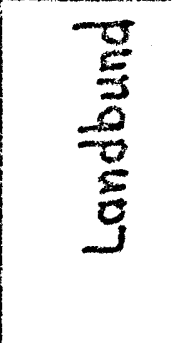 & $\sum_{a}^{2}$ & 害 & $\frac{\frac{n}{2}}{\frac{0}{5}}$ & 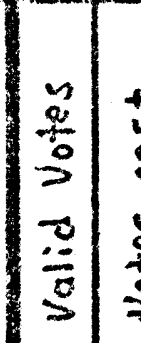 & \\
\hline
\end{tabular}




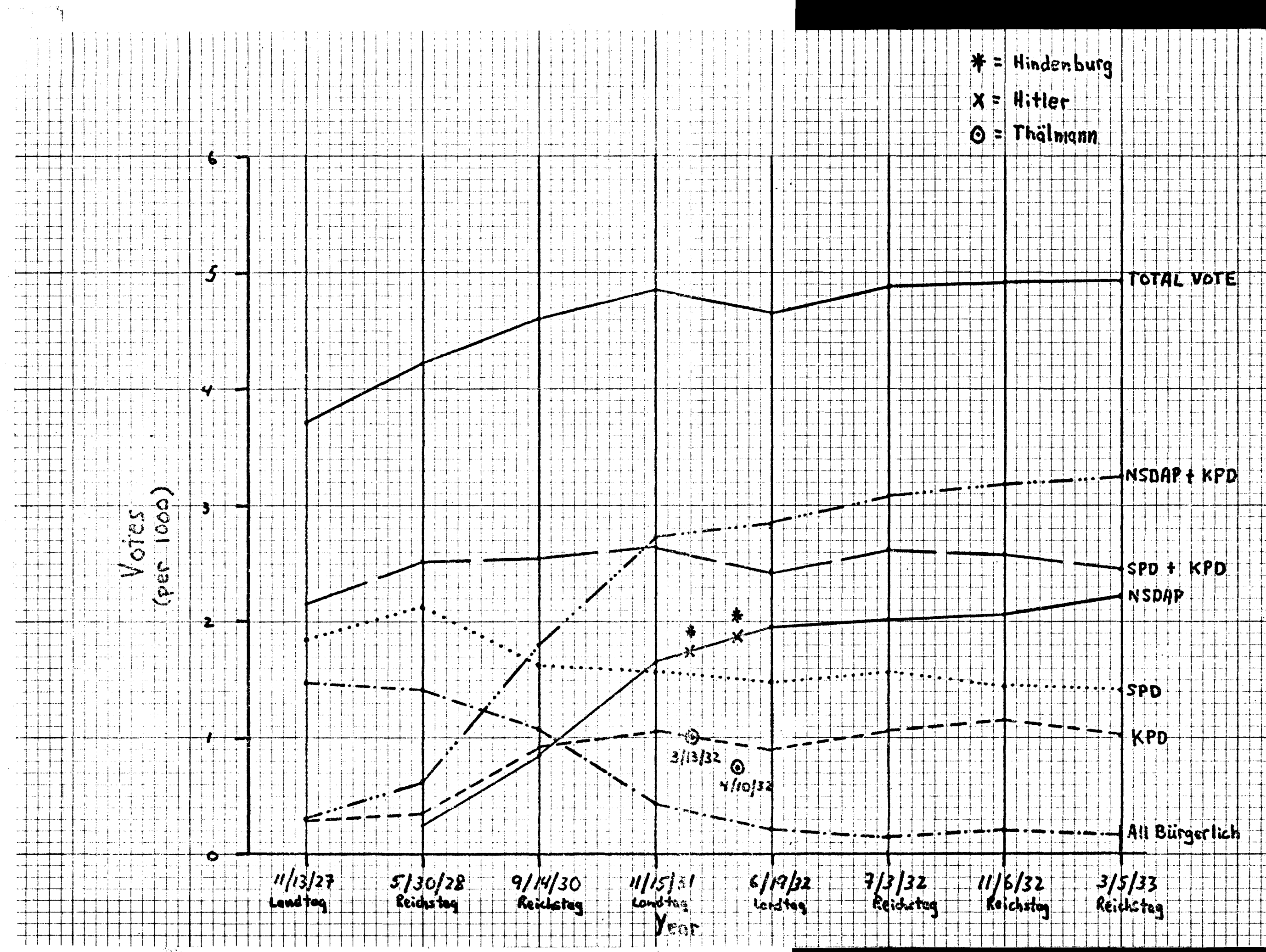


APPENDIX C

POPULATION FIGURES ${ }^{2}$

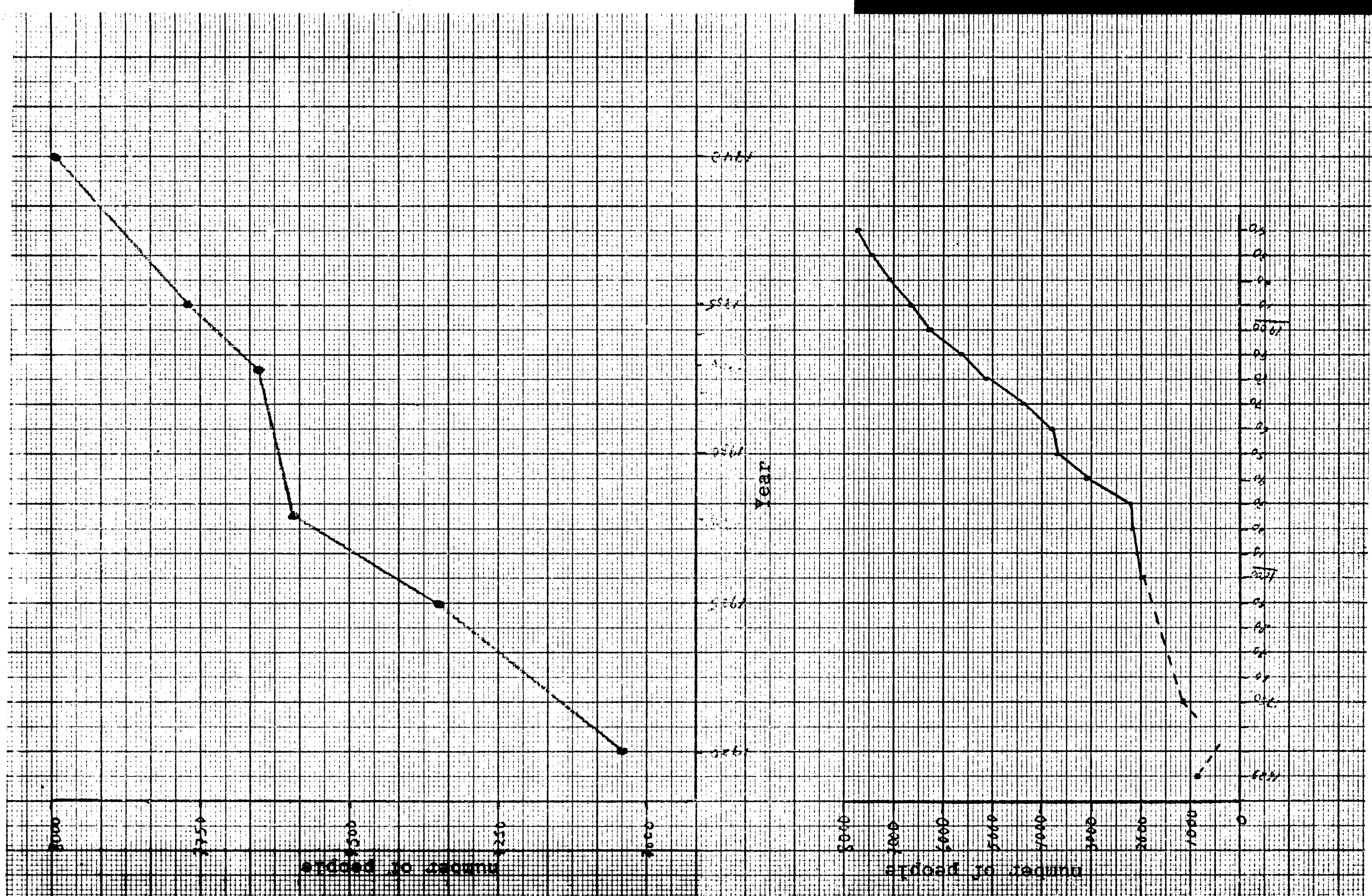




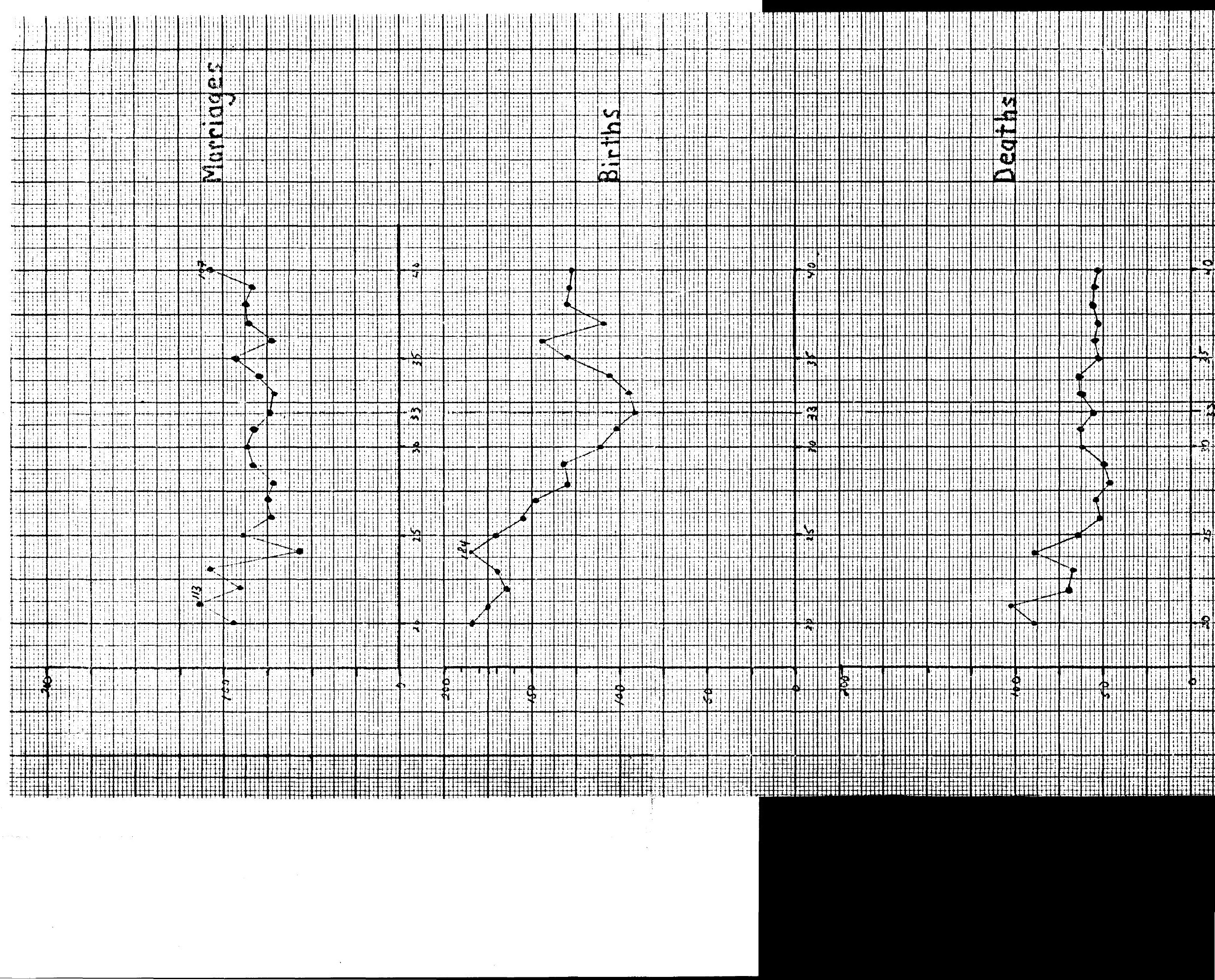


APPENDIX D

UNEMPLOYMENT ${ }^{3}$

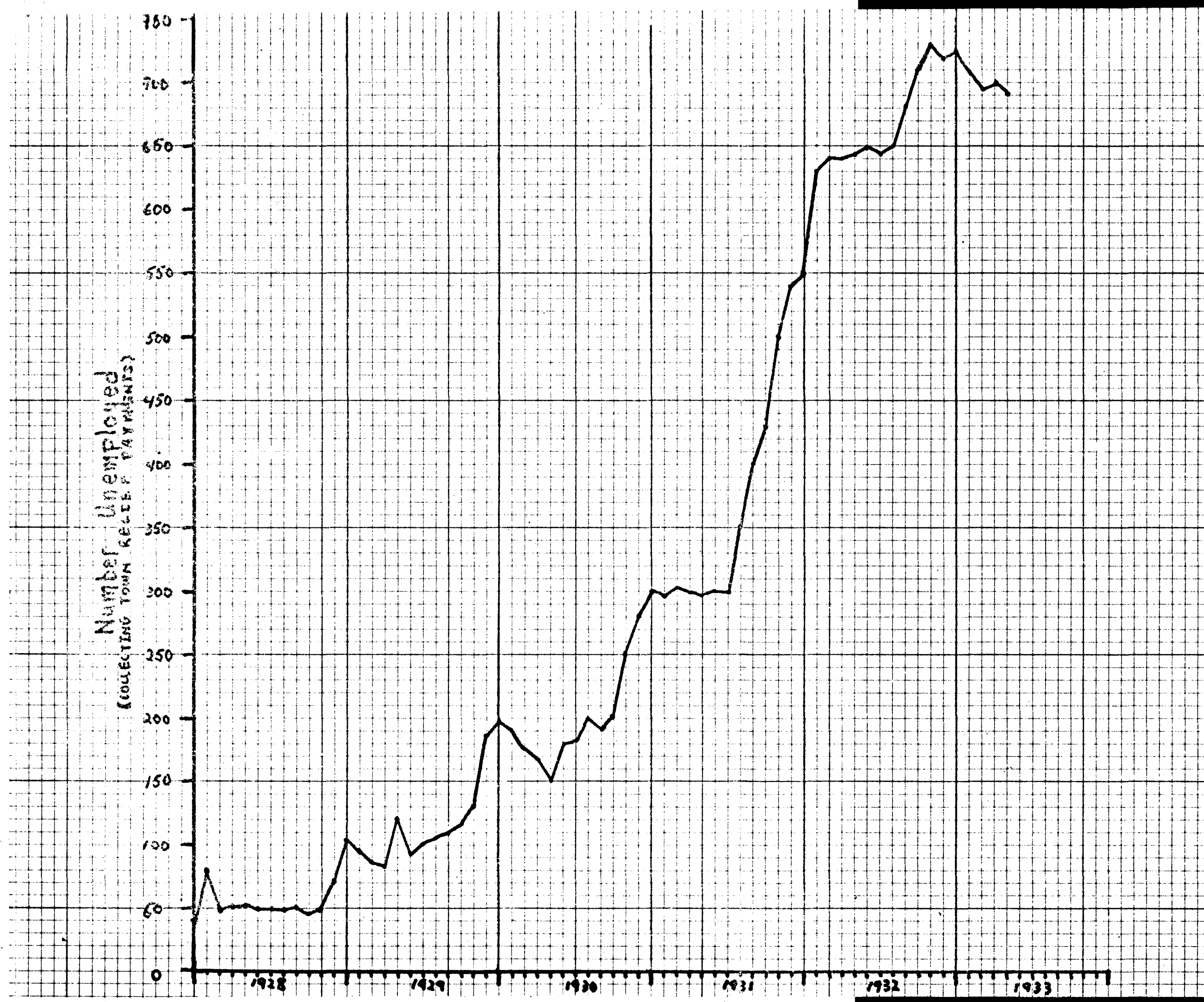




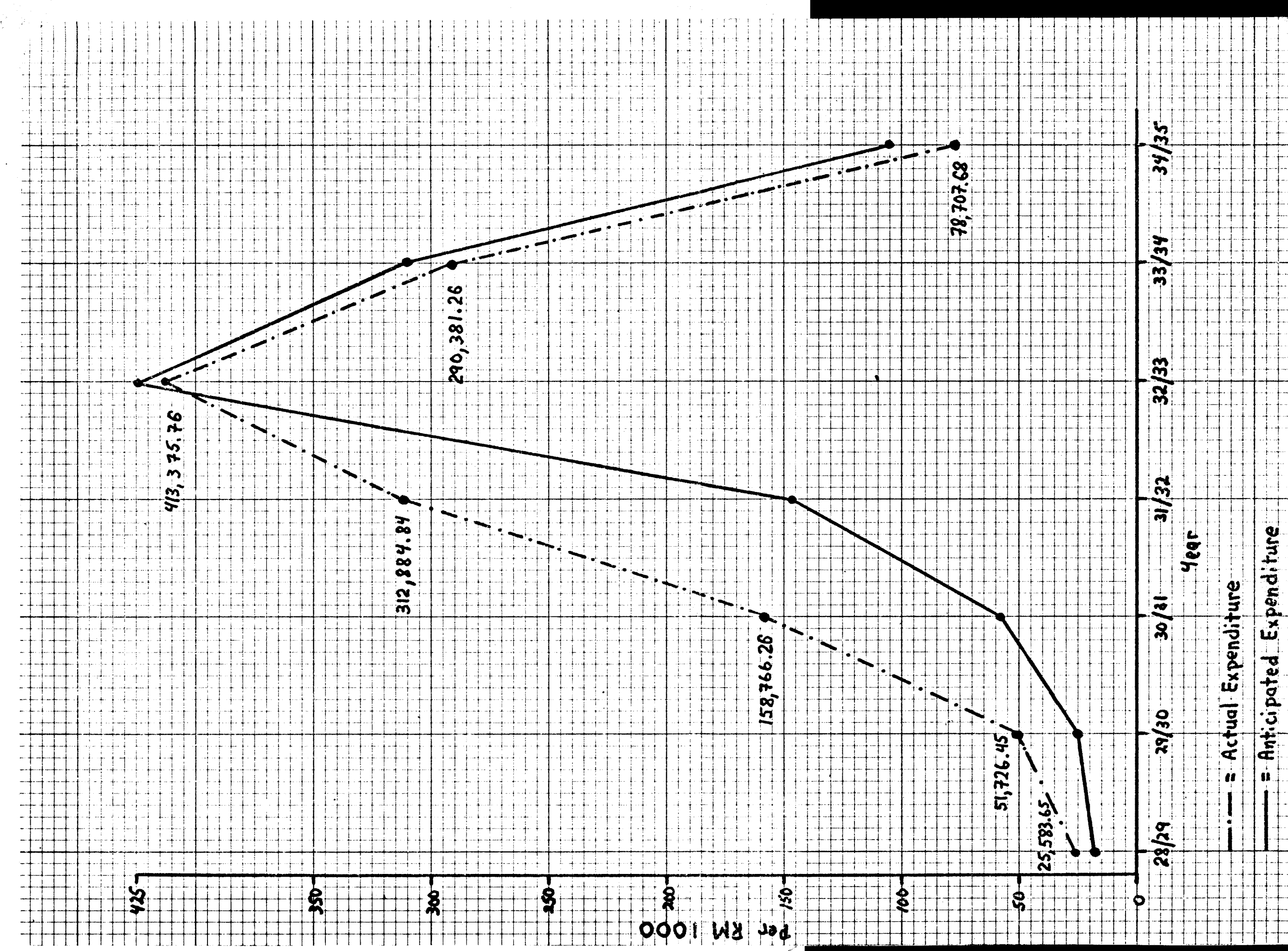


APPENDIX E

PUBLIC DEBT ${ }^{4}$

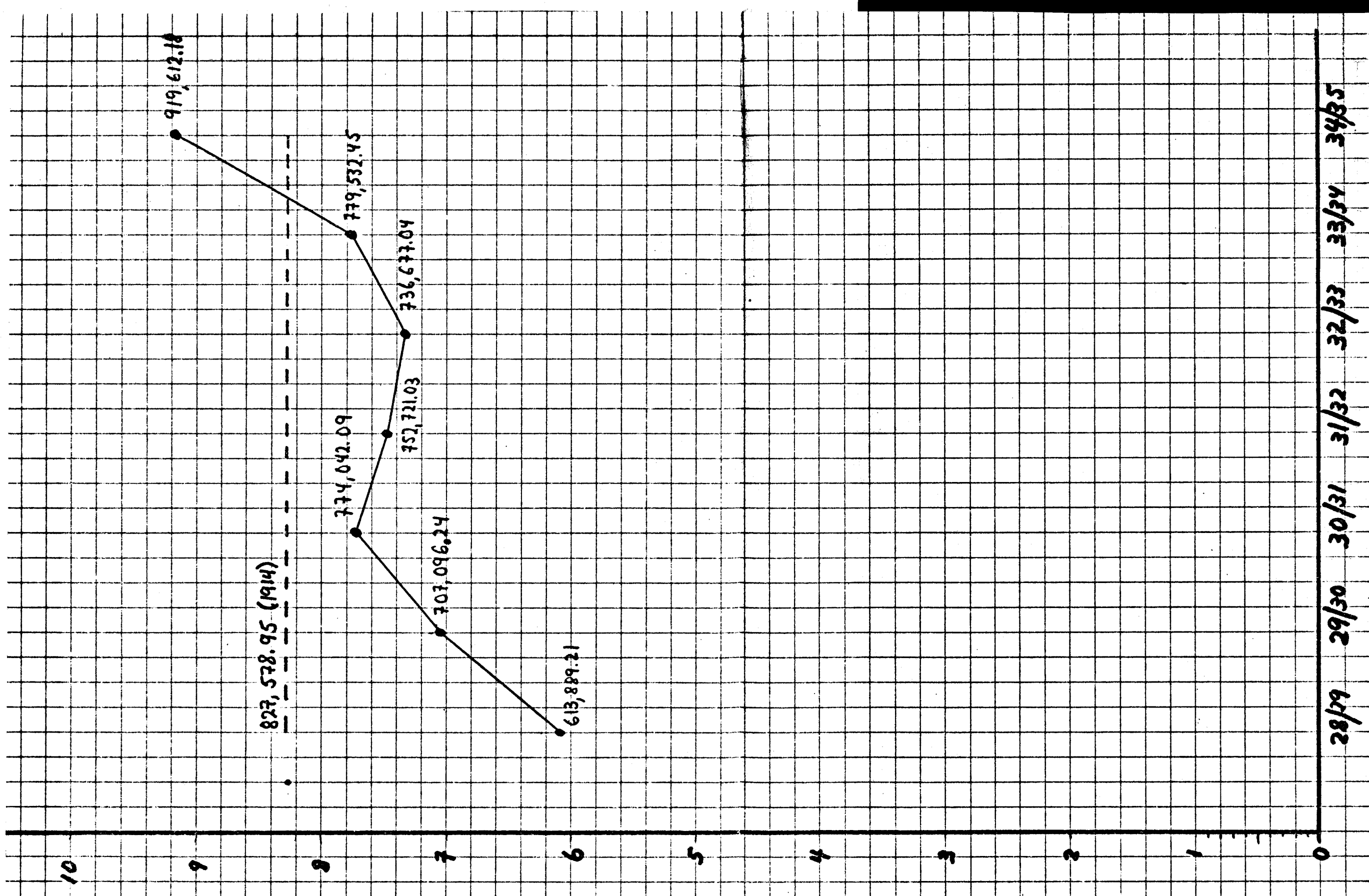

ocooos wis wid 
APPENDIX F

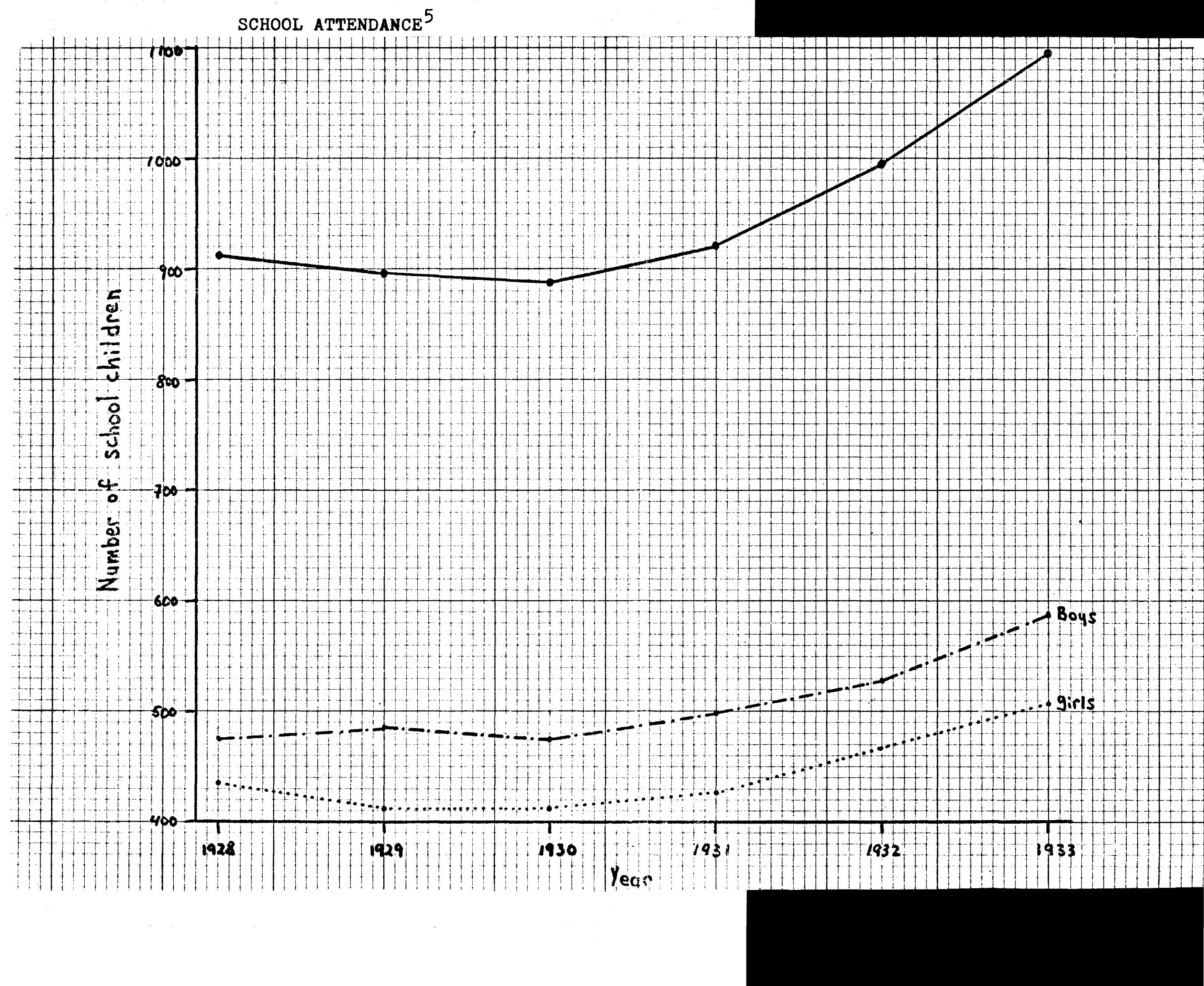




\section{APPENDICES - FOOTNOTES}

$I_{\mathrm{PA}}$ : November 14, 1927, May 6, 1928, September 15, 1930, November 15, 1931, June 20, 1932, Aügust 1, 1932, November 7, 1932 and March 6, 1933.

${ }^{2}$ Population figures supplied by the present town official, Phillip Hanbuch.

$3_{\mathrm{PA}}$ : monthly reports from 1928 to 1933 , discontinued after March, 1933.

${ }^{4}$ Rechnung über Einnahme und Ausgabe der Gemeinde Pfungstadt, 1928, 1929, 1930, $1931,1932, \overline{193} 3$ and 1934, pp. 124-126, 129-132, 132-134, 145-148 and 15̣7-160.

5pA: March 31, 1928, March 23, 1929, April 5, 1930, March 28, 1931, March 26, 1932 and Apri1 3, 1933. 